Historic, Archive Document

Do not assume content reflects current scientific knowledge, policies, or practices. 


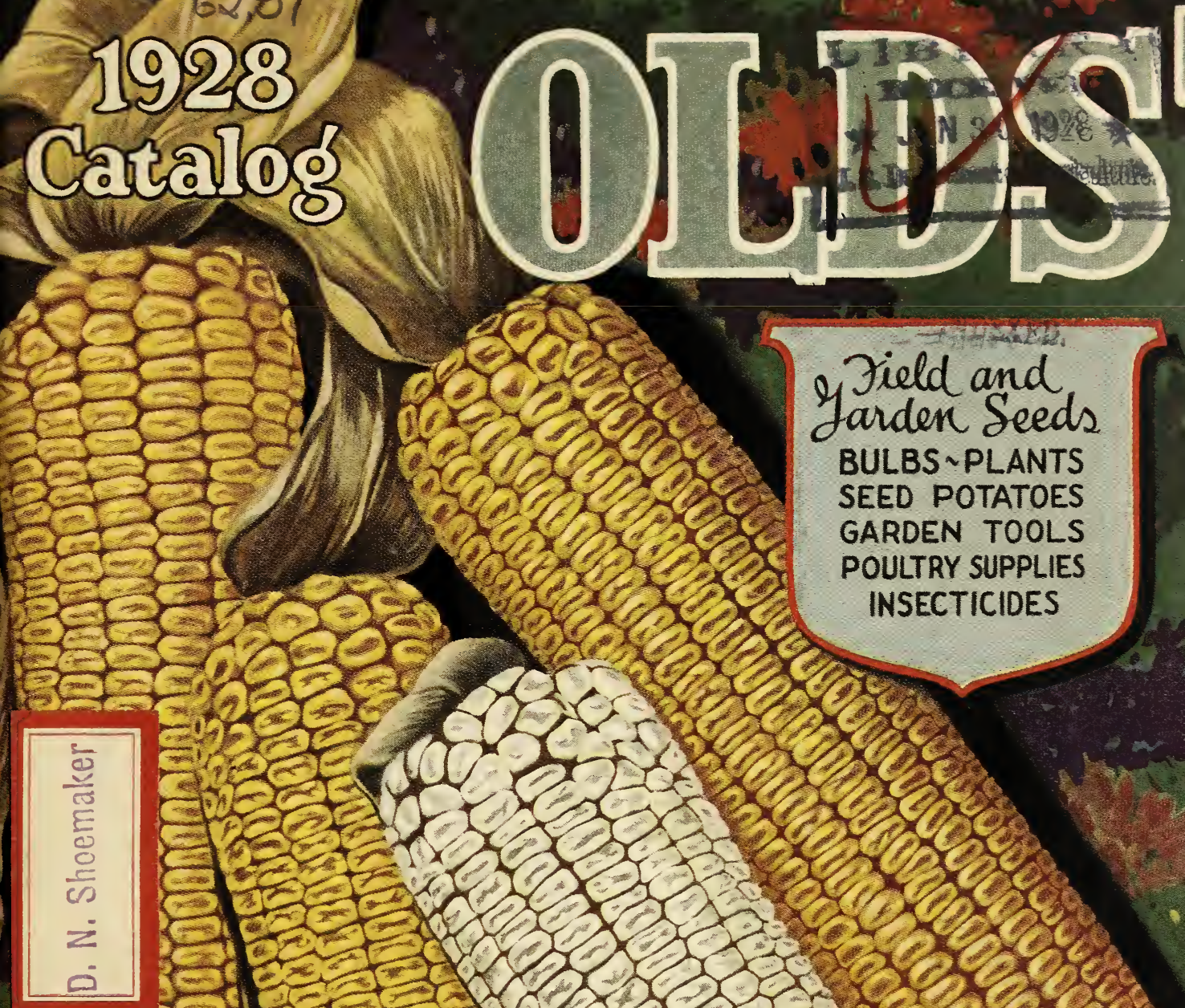

(2)

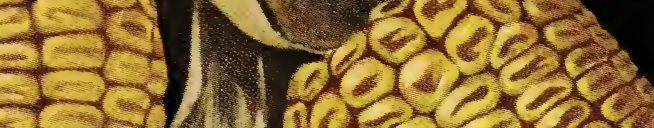

$-1-3-4$

1) $16 x+12020$

$-3+5 / 4$

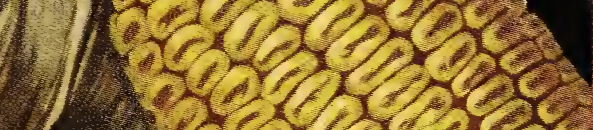

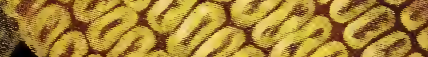

vele $191 \%$

14

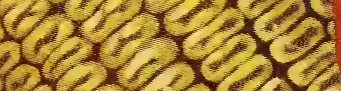

Yjueld and

BULBS PLANTS

SEED POTATOES

GARDEN TOOLS

POULTRY SUPPLIES

INSECTICIDES

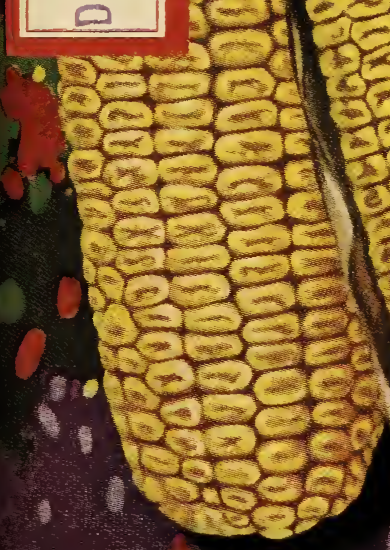

9. COLD

त)

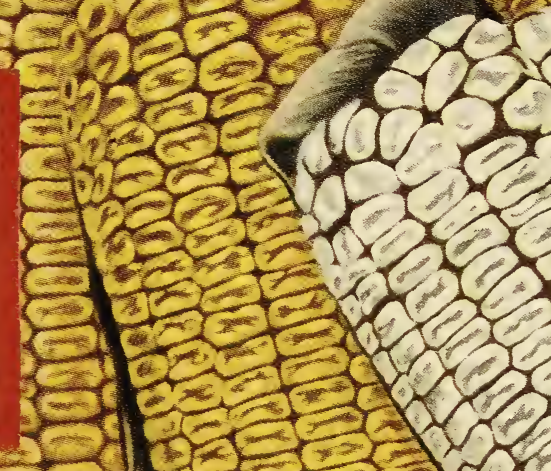

ienes?

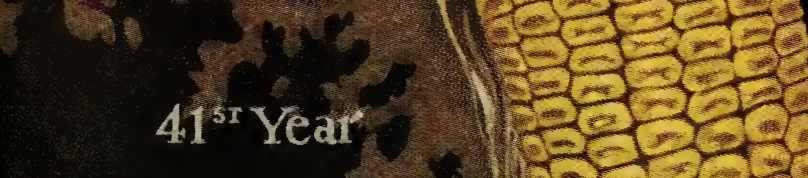

$41^{3 r}$ Year
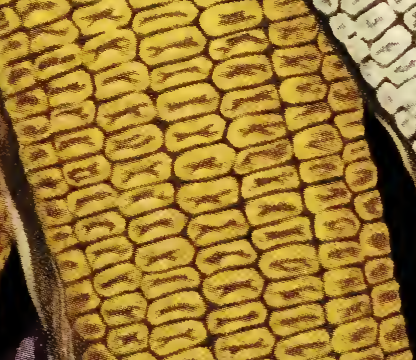
$12+1$ $-12,-1$

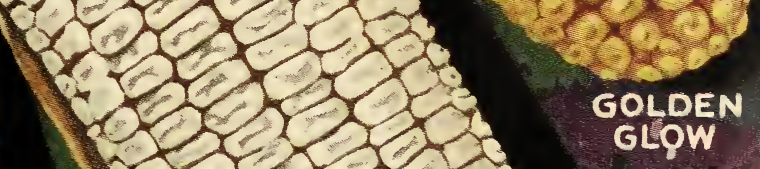




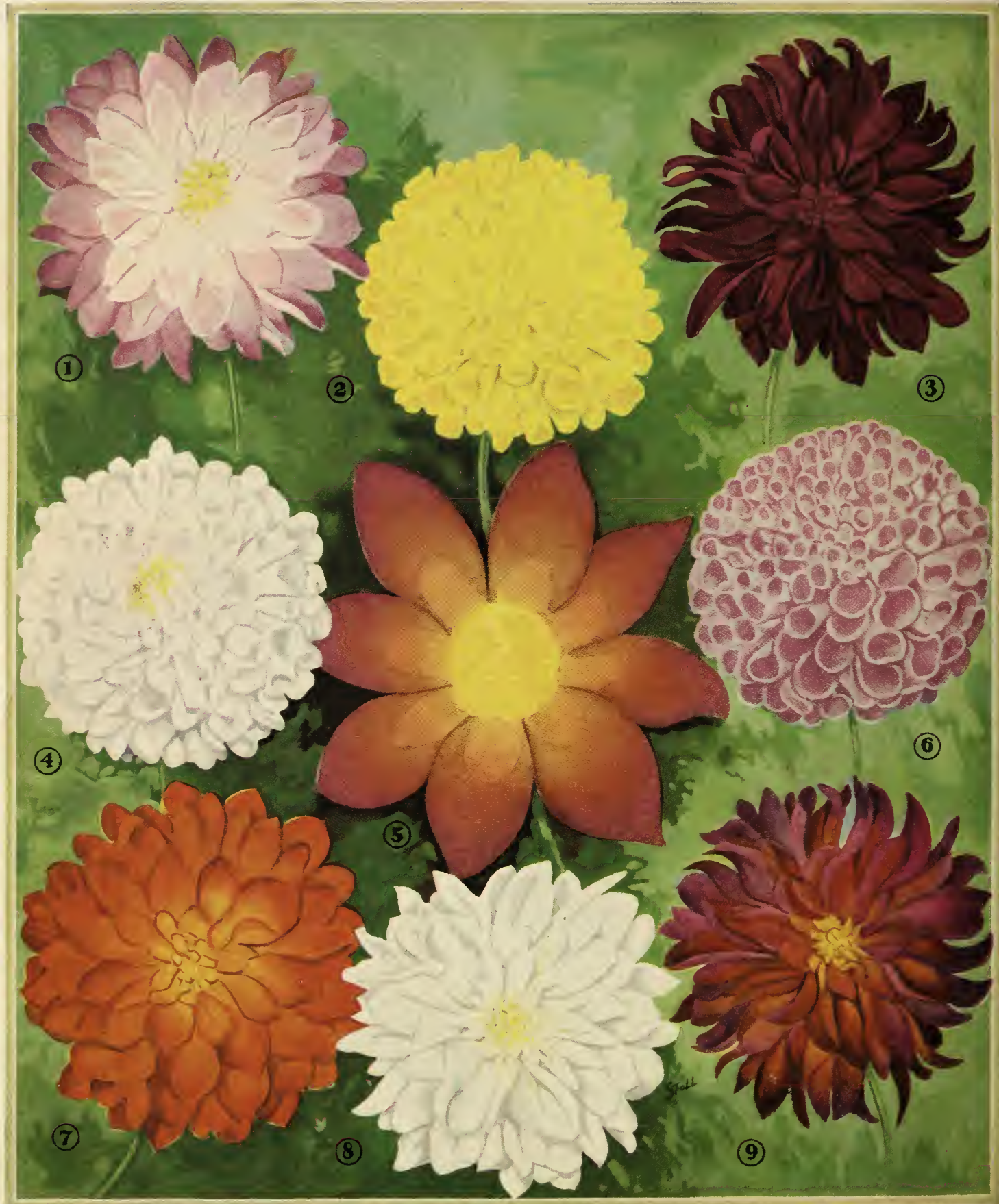

\section{OLDS'DAHLIA COLLECTION}

Nine Splendid Varieties for $\$ 1.50$ Postpaid

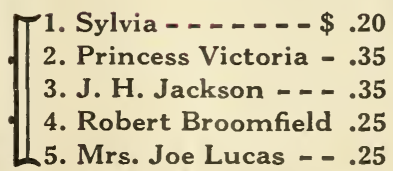

6. A. D. Livoni - \$.35 \. Special Price, One

7. Bronze Beauty - .25

8. Queen of Hearts .20

9. Blue Oban - - -.35

Total Value \$2.55

Bulb each, postpaid

5 Each Extra Large

Bulbs, by express

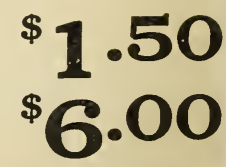

(See Pages 74 and 75 for Descriptions. Note attractive offer, “Olds' Finest Mixed Dahlias") 


\section{TO OUR FRIENDS AND CUSTOMERS}

Madison, Wis., Jan. 1, 1928.

FORTY YEARS we have been in the seed business and now start on our Forty First Year. The writer began in 1888 idh a "Choice Seed Potatoes." The business grew, other lines were added, 1888 with a small catalog devoted ex the present firm name. Our growth has been gradual but constant and as a result, We trust of satisfied customers.

BUSINESS INTEGRITY. We are members of the American Seed Trade Association, an organization which stands for "Business integrity, purity of stocks, honesty of representation, carefulness of obligations and promptness in execufor ", Ous constant purpose is to live up to these standards. We also hold a membership in the Farm Seed Association of North America.

"OLDS' CATALOG TELIS THE TRUTH." This has been our slogan for many years. We hope it is not merely an idle boast. The catalog is written with great care and we try not to exaggerate or misrepresent, as we want it to be an accurate guide for our customers in deciding just what to order for their particular needs. In the arrangement of the catalog, Field Seeds are given first place, then Garde

sery Stock and finally Tools, Fertilizers and Poultry supping you a very satisfactory season for 1928 , we remain,

We solicit your orders, and also your questions. Wishing you a very satisfactory

I. L. OLDS SEED COMPANY

\section{INSTRUCTIONS FOR ORDERING.}

PIFASE USE ORDER SHEET found in the catalog and retain a copy of your order. If you have occasion later on to write us about it give post office address under which it was mailed. Orders are filed by post offices, so if you give a different address it is difficult to find the order.

WE ACKNOWIEDGE ORDERS when received unless some part is to be sent at once. If any part of the order is mailed right out that answers as an acknowledgment or if goods can be sent at once by freight or express we get them right out, sending acknowledgment and notice of shipment at the same time, enclosing Bill of Lading.

WE SEND LARGE SHIPIMENTS BY FREIGHT unless otherwise instructed. See table of freight rates below. We have three railroads here at Madison, C. \& N. W., C. M. \& St. P., and I. C.

CUSTOMERS PAY TRANSPORTATION CHARGES on all goods unless offered postpaid. Small shipments will ordinarily be sent by express unless ordered by mail or unless the price includes postage. Our garden seed prices in mall quantities are postpaid prices, but prices on field seeds and side lines do not include postage unless so stated. There are special express rates on seeds, in the main, 25 per cent less than the merchandise rates.

ORDER EARLY. Do this for two reasons. We can give your orders more careful and prompt attention if received before we get into the rush, and the

\section{OUR THREEFOLD GUARANTEE.}

1. QUALITY. We guarantee the quality of the seeds, plants, bulbs and potatoes we send out to the extent that should they not prove as represented we will refill the order or return the money; but we give no further warranty, express or implied, as to description, quality, productiveness or any other matter of any seeds, potatoes, bulbs or plants we send out and will not be responsible for the crop. Goods may be returned if not satisfactory.

2. SAFE ARRIVAI. We guarantee everything to arrive in good order. If potatoes freeze on the road we will refill the order if the time of shipping is left to our discretion. If any goods arrive in bad order, however, bags torn or anything else wrong, have this noted on the freight expense bill which must be sent us so that we can make proper claim. The bill of lading must be returned also. Therefore do not lose the bill of lading.

3. RECEIPT OF MONEY. We will be responsible for all money sent us through the mails, if remittance is made by P. O. or Express Order, Draft or Registered Letter. We will accept personal checks at face value. Ther look good to us. Small amounts, less than $\$ 1.00$, may usually be sent safely in postage stamps or coin

\section{PRICE CHANGES.}

It is impossible to anticipate in advance all our requirements especially in some staple items or to foresee market changes. Accordingly we reserve the right to change the prices of Field Seeds if necessary after Feb. 1 st. Beginning with that date we issue weekly price lists of Field Seeds giving the prices in effect each week. These price lists are furnished on application and enclosed in catalogs mailed after Feb. 1st. The prices on Garden Seeds and on Side Lines, with just a few exceptions, will remain throughout the season as given in the catalog and we do not expect there will be many changes in the Field Seed prices but there are sure to be some.

\section{FREIGHT RATES FROM MADISON, WIS., IN EFFECT JAN, 1, 1928.}

Per 100 Ibs. in Bags, Barrels, Bozes, etc. Iess than Car Iots, to Points Named Below.

(Clovers, Grass Seeds, Garden Seeds and Potatoes go as third class; Grain, Corn, Poultry Food, etc., fourth class.)

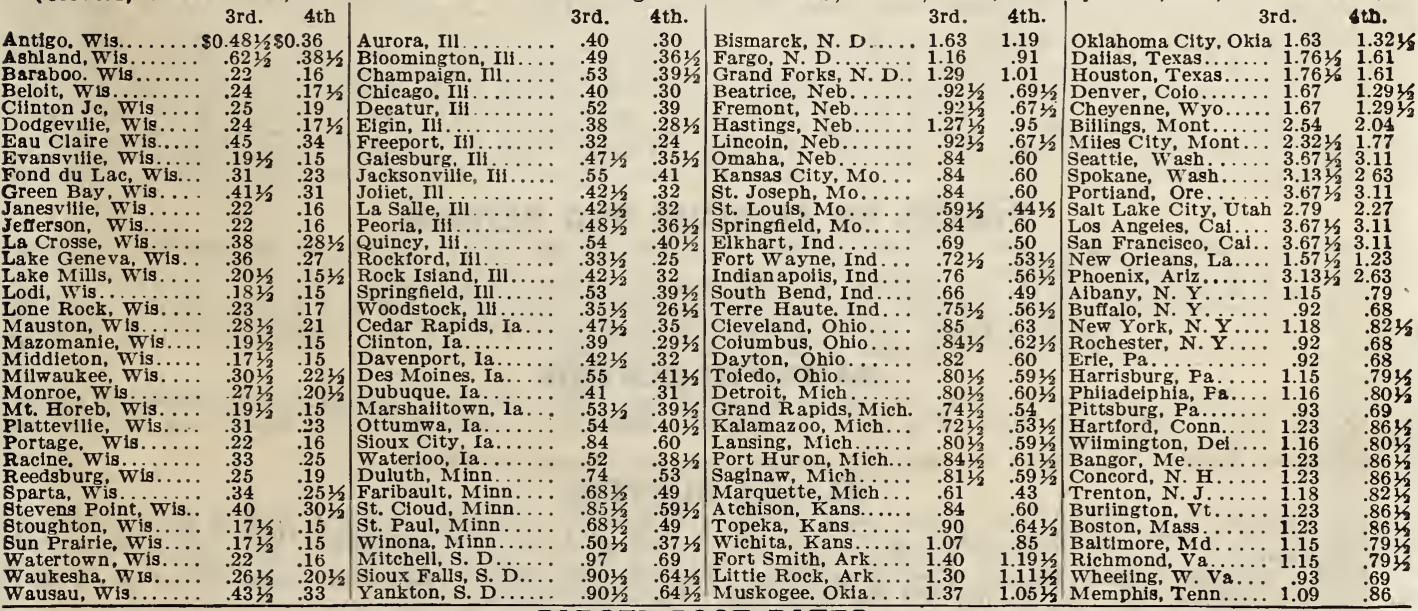

\section{PARGEL POST RATES}

1st and 2nd Zones (up to 150 miles from Madison) $7 \mathrm{c}$ for the first pound, 1c for each additional pound. 3d Zone (151 to 300 miles from Madison) $8 \mathrm{c}$ for the first pound, 2c for each additional pound.

4 th Zone (301 to 600 miles from Madison) $9 \mathrm{c}$ for the first pound, $4 \mathrm{c}$ for each additional pound.

5 th Zone ( 601 to 1,000 miles from Madison) 10c for the first pound, 6c for each additional pound.

6 th Zone (1,001 to 1,400 miles from Madison) 11c for the first pound, $8 \mathrm{c}$ for each additional pound.

7 th Zone (1,401 to 1,800 miles from Madison) 13c for the first pound, $10 \mathrm{c}$ for each additional pound.

8th Zone (over 1,800 miles from Madison) 14c for the first pound, 12c for each additional pound Packages must not exceed 70 pounds in weight for the first three zones, and 50 pounds for all other zones. 


\section{OLDS’ CLOVER SEED.}

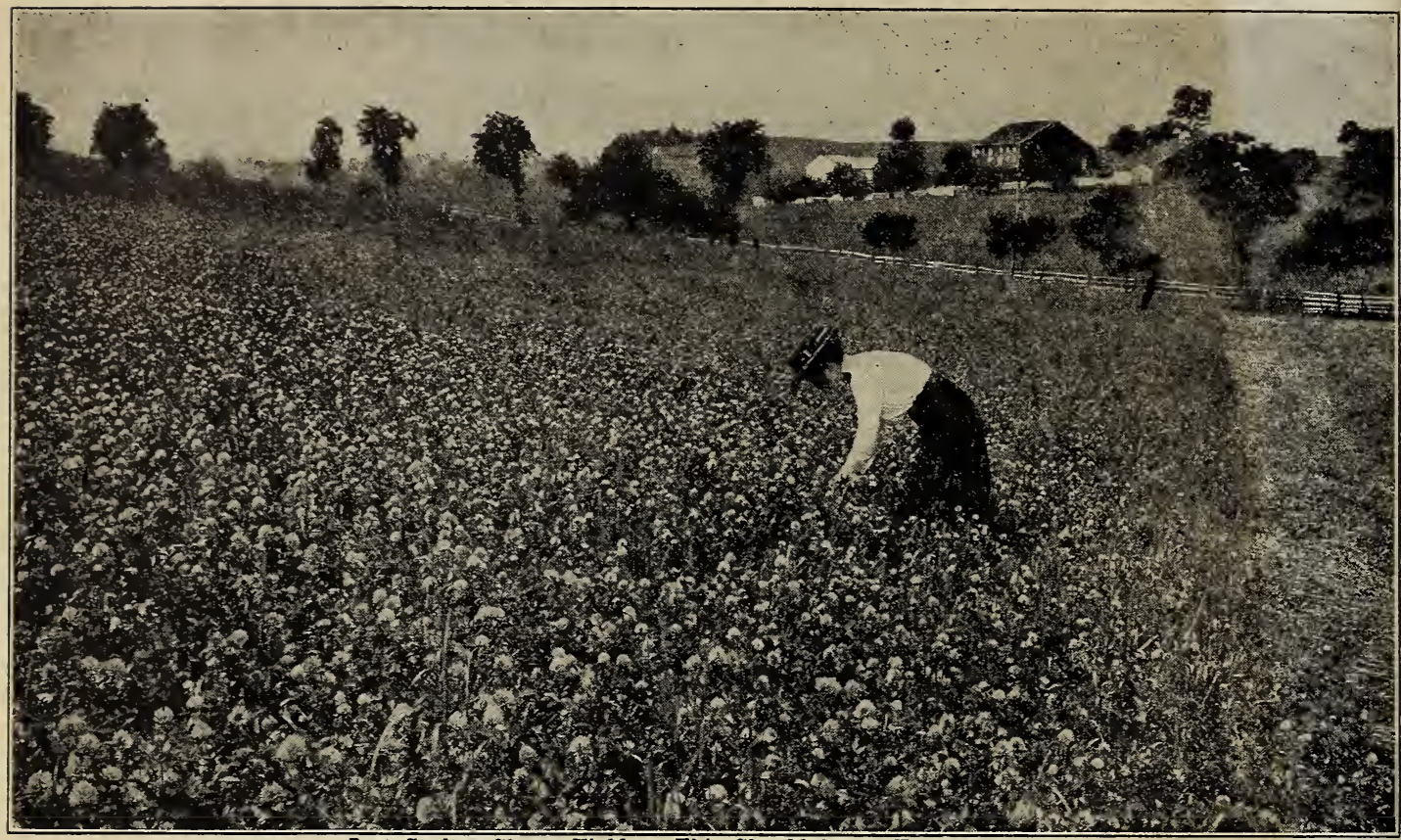

Just Such a Clover Field as This Should be on Every Farm.

\section{OLDS' WISCONSIN GROWN CLOVER SEED}

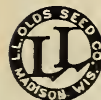

Our High Testing Recleaned Wisconsin Grown Clover Seed Has Won a Reputation. It is the best seed obtain able. Wisconsin is a leading clover state and the crop the past season was unusually fine. In fact Wisconsin stood second in clover seed production in the list of states, being surpassed only by Ohio. We are in position to buy this high grade Wisconsin seed right from first hands and we have laid in a fine large stock for our customers. This seed has all been thoroughly recleaned through our own cleaning plant and it is all hightesting seed, entirely free from buckhorn and dodder and all other noxious weeds.

VERIFIED ORIGIN. All our Medium and Mammoth Clover Seed this year is "U. S. Verified Origin Seed." This

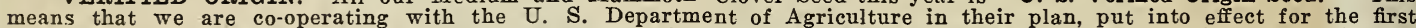
time this year, for verifying the locality where grown of every lot of Medium and Mammoth Clover. Government inspec-

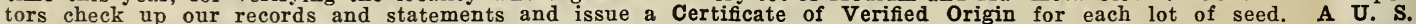

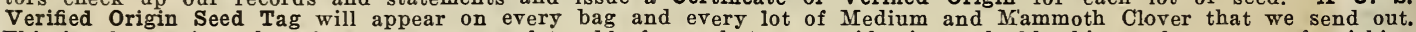

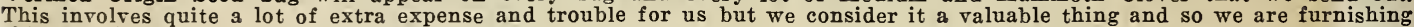
this additional service to our customers.

SOW IIBERALLY THIS YEAR. Clover prices this year are the lowest since 1924. Many farmers have neglect-

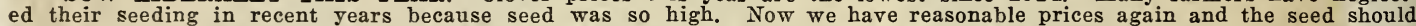

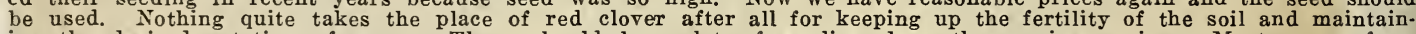

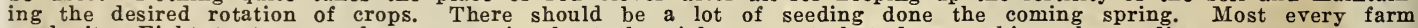
needs it. Eight to ten pounds per acre is about the right amount, but do not skimp the seeding.

CLOVER PRICES. Our prices are good until February 1 st only. There is no likelihood that prices will be any

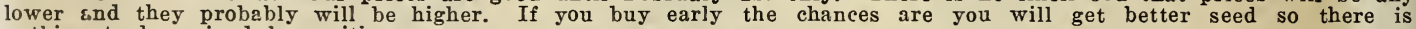
nothing to be gained by waiting anywa

\section{PRICES OF MEDIUM RED CLOVER}

Superb Brand-By mail: Lb., 55c. By freight: Lb., 50c; 1/2 pk., $\$ 3.10$; pk., $\$ 6.00$; bu. (60 Ibs.), $\$ 22.90$; 100 lbs. $\$ 38.00 ; 500$ lbs, at $\$ 37.50$, Bags extra at $35 \mathrm{c}$

Old Gold Brand: Pk., $\$ 5.75$; bu., $\$ 21.70 ; 100$ lbs., $\$ 36.00 ; 500$ lbs. at $\$ 35.50$.

(Our "Superb Brand,"; which is Idaho grown, is extra bright and extra fancy seed with a purity test of about 99 per cent or better. Our "Old Gold Brand," our best Wisconsin seed, of which we sell the most and which is perfectly all right, good enough for anyone, tests around 98 to 99 per cent purity.)

Resembles Medium but larger. Best for pasture and fertilizer. Our stock is all Wisconsin and Minnesota grown. Prices, Superb Brand-By mail: Lb., 55c. By freight: Lb., 50c; 1/2 pk., \$3.20; pk., $\$ 6.15 ;$ bu., $\$ 23.50 ; 100$ lbs., $\$ 39.00 ; 500$ lbs. at $\$ 38.50$.

old Gold Brand: Pk., $\$ 5.85$; bu., $\$ 22.30$; 100 lbs., $\$ 37.00 ; 500$ lbs. at $\$ 36.50$.

\section{ALSIKE CLOVER.}

Finer and more leafy than Red Clover, but grows to a good height and makes a heavy yield of hay. Alsike is very reasonable in price this year and it goes much farther than Red Clover in seeding. Our seed is nearly all Wisconsin

Prices, by mail-Superb Brand. Very fancy stock. Lb., 50c. By freight: Lb., 45c; 1/2 pk., \$2.85; pk., \$5.50; bu. $(60$ lbs.), $\$ 20.50 ; 100$ lbs., $\$ 34.00 ; 500$ lbs. at $\$ 33.50$. Bags extra at $35 \mathrm{c}$.

Old Gold Brand: Pk., $\$ 5.20$; bu., $\$ 19.30 ; 100$ lbs., $\$ 32.00 ; 500$ lbs. at $\$ 31.50$

Lakes Brand. Contains about 8 per cent White-Pk., $\$ 4.90 ;$ bu., $\$ 18.10 ; 100$ 1bs., $\$ 30.00 ; 500$ at $\$ 29.50$

WHITE DUTCH CLOVER. Very fine for lawns. Our seed is all Wisconsin grown.

Prices, by mail-superb Brand: Lb., 60c; 3 lbs., \$1.65. By freight: Lb., 55c; 1/2 pk., \$3.25; pk., \$6.25;

bu. (60 lbs.), $\$ 22.80 ; 100$ lbs. $\$ 38.00$.

Old Gold Brand: 'Pk., $\$ 5.75$; bu., $\$ 21.10$; 100 lbs., $\$ 35.00$.

Note: Prices named here are good until Feb. 1st only. After that ask for our "Weekly Price List."

Samples giving purity and germination tests, free on request. Bags extra at $35 \mathrm{c}$. 


\section{Premiums For January and February Orders}

On request, with an early order amounting to $\$ 2.00$ or more, we will send free at planting time, One Red Everblooming Hybrid Tea Rose Bush.

On request, with an order amounting to $\$ 4.00$ or more, we will send free at planting time, Three Everblooming Hybrid Tea Rose Bushes (all different)

\section{This Offer Expires Promptly on February 29, 1928}

It costs less to handle orders early in the season before the rush begins, and we will gladly pass the saving along to you, if you will let us have your order to fill before March first.

March and April are extremely busy months in the seed trade, January and February less so. Every order we fill before March means just that much work out of the way. And so, in order to induce more of our customers to send early, and in appreciation of those who do, we are going to give away a few thousand CHOICE ROSE BUSHES. They are a mighty fine lot of selected plants of Beautiful Everblooming Hybrid Tea Roses, of good size and shape for mailing and well rooted for transplanting.

We chose roses because they are readily transplanted, are easy of cultivation, grow in almost any soil, and because no matter how many roses you may have, more are sure to be welcome.

The Rose is "The Queen of Flowers." SEND YOUR ORDER EARLY

\section{L. OLDS SEED COMPANY}

MADISON, WIS.

(SEE OTHER SIDE) 


\section{BEAUTIFY YOUR HOME}

\section{Have Attractive Flowers on Your Lawn}

Have you ever stopped to think how a few flowering plants and ornamental shrubs placed about your lawn will help to beautify your home? Just a few properly placed about the yard will convert an unattractive lawn into a beautiful and pleasing place. It does not require a great outlay, just a few dollars and a little enjoyable work.

A few roots of Peonies and Iris, some Glads and Dahlias, plus a few ornamental shrubs, such as Bridal Wreath, Hydrangeas and Roses, will work wonders in the appearance of your home. You will find all these and many others offered in our catalog. See pages 71 to 84 .

Order now and we will send them out at the proper time for planting. Plant them carefully when they arrive and by mid-summer you will be enjoying the blooms and their fragrance. You will also have the pride and satisfaction of knowing you have a well kept home. No matter how nice your house an unattractive lawn makes it merely a house and only a house.

For a start resolve to put in some Dahlia bulbs at any rate. You can buy a dozen of Olds' Finest Mixed Dahlias, all colors and shades, bulbs of our own growing, for only $\$ 1.25$ postpaid. These are very easily planted and sure to give satisfaction. Or order Olds' Dahlia Collection, 9 Distinct Varieties, for $\$ 1.50$ postpaid.

Have some Gladioli, too, 12 Separate Varieties, Olds' Gladiolus Collection, for $\$ 1.00$ or 100 Olds' Superb Mixture for $\$ 2.25$, postpaid.

We feel sure that after once making a start along this line you will want to do more another year and will experience the utmost pleasure and satisfaction in this kind of work.

Make Your Lawn the Envy of Your Neighbors

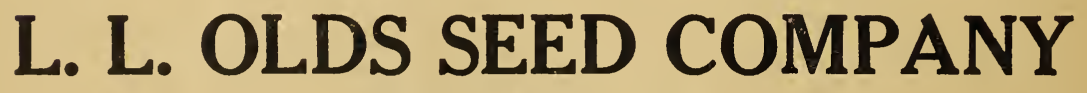

MADISON, WIS.

(SEE OTHER SIDE) 
"Sweet Clover has an important place in the livestock agriculture of Wisconsin, although it was once regarded as a wayside weed." -Wisconsin Bulletin No. 178.

REASONS FOR SWEET

CLOVER'S VALUE:

First-Easily Grown. It grows readily on most all soils and good stands can of ten be secured where Red Clover and Alfalfa fail entirely.

Second-Prepares for Alfalfa. It has the same sort of bacteria laden nodules as alfalfa and inoculates for that crop.

Third-A Great Pasture Crop. It can be pastured while alfalfa cañnot. Leading farmers everywhere are very enthusiastic now over sweet clover as a pasture crop. It makes more feed per acre than the common permanent pastures.

Fourth-Wonderful Soil Builder. It is a better soil builder than either red clover or alfalfa because it grows faster and larger and the

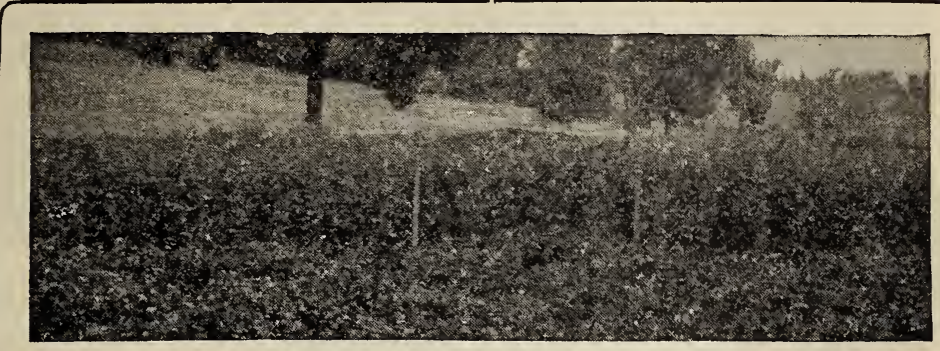

Sweet Clover Grows Faster Than Alsike or Red.

(Courtesy Wisconsin College of Agriculture)

roots penetrate deeper into the soil.

Fifth-Good Hay Crop. It produces valuable hay, almost equal in value to alfalfa hay and all stock learn to like it.

CULTURE. Sweet clover is best sown in the spring with one bushel of extra early oats per acre as nurse crop. Sweet Clover can also be sown successfully in June or July without a nurse crop, but spring sowing is preferable.

Fifteen Pounds of Seed per Acre is usually sufficient, a little less for Grundy County as the seed is smaller. Inoculate the seed before sowing. Use lime if your soil is sour. Be sure to have a good seed bed. Most any well-drained soil is all right for Sweet Clover and you will be pleased with the crop if you do your part in putting it in and handling it right. Ask for Wisconsin Bulletin No. 178, "How to Gro w Sweet Clover."

SEED LOWEST IN PRICE. The Sweet Clover Seed crop the past season was very large and fine and prices this year are the lowest on record. If you have never tried Sweet Clover now is the time to start when the seed is so cheap. Prices probably will never be as low again and furthermore, the quality of the seed is of the best. We have a splendid large'stock on hand grown mostly in North Dakota where the best seed is produced.

\section{VARIETIES OF SWEET CLOVER. \\ COMMON WHITE BLOSSOM.}

The best probably for pasture and for soil building and the most largely sown for all purposes.

Prices-Superb Brand-By mail: Lb., 30c. By freight: Lb., 25c; $1 / 2$ pk., 95c; pk., $\$ 1.75$; bu. $(60$ lbs.), $\$ 6.40 ; 100$ lbs., $\$ 10.50 ; 500$ lbs., at $\$ 10.25$. Bags extra at $35 \mathrm{c}$. old Gold Brand: Pk., \$1.65; bu., $\$ 6.10 ; 100$ lbs., $\$ 10.00 ; 500$ lbs. or over at $\$ 9.75$.

\section{GRUNDY COUNTY}

This is the famous dwarf strain of Sweet Clover originated in Grundy County, Illinois. It is much better for hay than the Common White Blossom because it is finer and more leafy, also because more easily handled on account of its dwarf growth.

We have a splendid large stock of beautiful Grundy County seed to offer this year and we recommend it most highly. For pasture and for fertilizer it is we think just as good as the Common and for hay it is very much superior. It is about 10 days earlier. The seed goes further because smaller.

Prices-Superb Brand-By mail: Lb., 30c. By freight: Lb., 25c; $1 / 2$ pk., $\$ 1.00$; pk., $\$ 1.80$; bu., $\$ 6.55 ; 100$ lbs., $\$ 10.75 ; 500$ lbs. at $\$ 10.50$.

Old Gold Brand: Pk., \$1.70; bu., \$6.25; 100 Ibs., \$10.25; 500 lbs. at $\$ 10.00$.

\section{YELLOW BLOSSOM BIENNIAL.}

This is the large strain of Yellow Sweet Clover, biennial the same as the Common White. Some say it is better for pasture than the White because it stays green longer. A little earlier than the White.

Prices: $1 / 2$ pk., 95c; pk., $\$ 1.75$; bu., $\$ 6.40$; 100 lbs., $\$ 10.50$; $500 \mathrm{lbs}$, at $\$ 10.25$. Pound prices same as for White.

\section{ALBOTREA YELLOW BLOSSOM.}

Albotrea is a new strain of Dwarf Yellow Blossom Sweet Clover originated in Canada. Albotrea has been grown several seasons on the Wisconsin Experiment Station Farm and they think very highly of it there. They say it is much to be preferred to the regular Biennial White Blossom and they like it better than Grundy County because they say it gives higher yields both of hay and seed.

Prices-By mail: Lb., 40c; 3 lbs., \$1.10. By freight: Lb., $35 \mathrm{c}$; $1 / 2$ pk., $\$ 1.90$; pk., $\$ 3.50$; bu., $\$ 12.25$; 100 lbs., $\$ 20.00$; $500 \mathrm{lbs}$. at $\$ 19.50$.

\section{HUBAM. (The Annual Sweet Clover.)}

Produces a full crop of both hay and seed all in one year.

Prices-By mail: Lb., 45c. By freight: Lb., 40c; $1 / 2$ pk., $\$ 2.50$; pk., $\$ 4.90$; bu., $\$ 18.15 ; 100$ lbs., $\$ 30.00$.

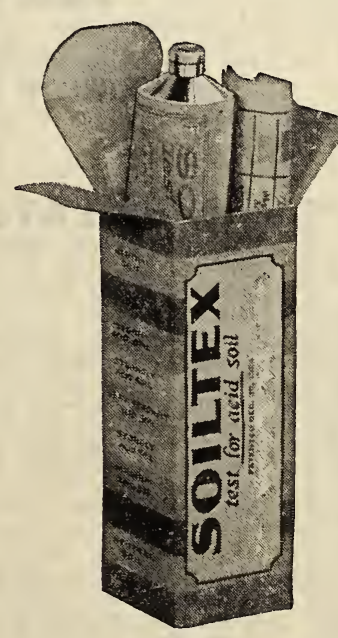

TEST FOR ACID

Soiltex is a new, quick, easy and accurate soil testing method, developed at the Michigan Agricultural College, whereby you can determine exactly in a few minutes whether or not your soil is acid and how much lime it needs.

Many farms fail to grow alfalfa and sweet c lover successfully, and other crops as well, because needing lime. Lime corrects acidity, sets plant food free, improves the soil and is necessary to the activity of nitrogengathering bacteria.

Test your soil yourself with Soiltex and learn exactly what it needs.

Each outfit will make 75 to 100 tests. Full directions, color chart and lime table included. No special knowledge or equipment required. Costs less than 2 cents per sample tested. Soiltex will save you money.

Price, $\$ 1.00$ postpaid. 


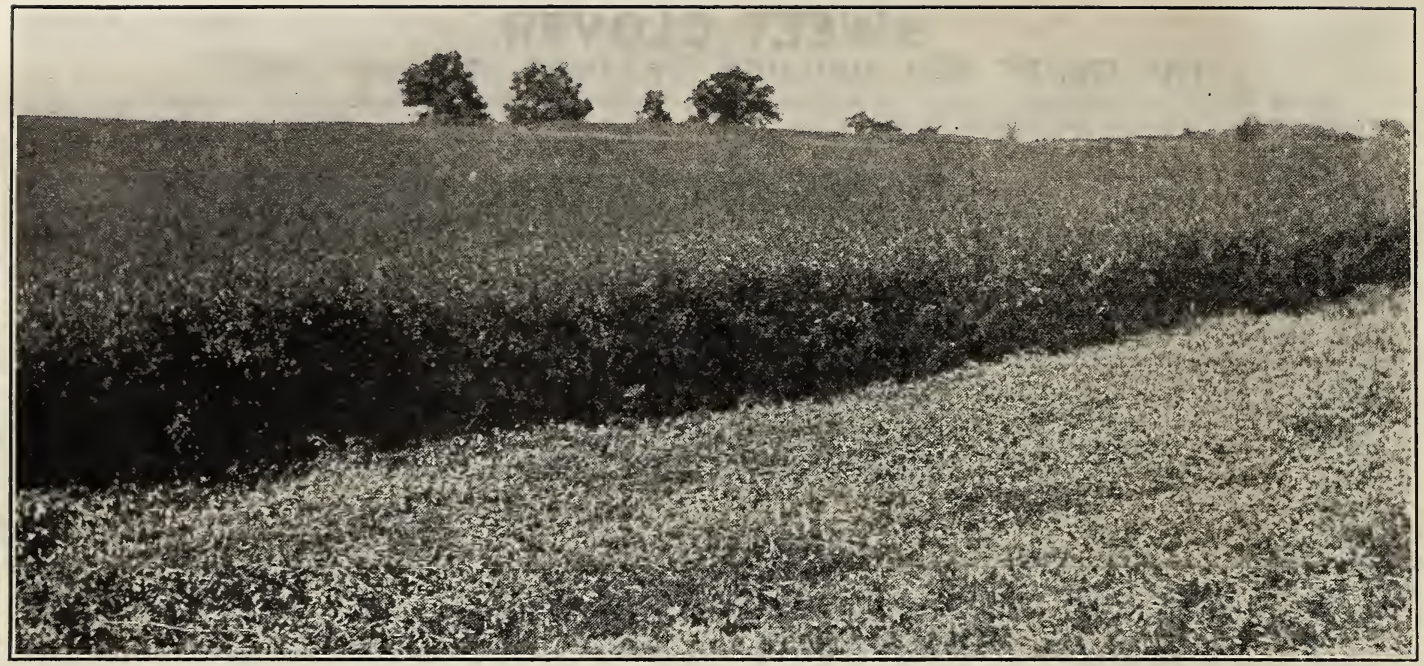

Splendid Alfalfa Field on Farm of Swartz Bros., Waukesha County, Wisconsin. This Should be Duplicated on Every Farm.

\section{OLDS' FANCY ALFALFA SEED}

"Alfalfa has become an economic necessity in Wisconsin agriculture." -Wisconsin Bulletin 374. We make a specialty of Fancy, High-Grade Alfalfa Seed, handling many carloads every year. We securt
the best seed obtainable, the purest and hardiest. Our seed can be fully relied on.
OERIFIED ORIGIN, Practically all the alfalfa seed we send out this vear will be either "U. S. Verified
Origin Seed,', the same as our Clover Seed, or State Sealed and Certified Seed. See what we say about

ALFALFA PRICES. The catalog prices are good until February 1st only. Ask for "Weekly Price List" after that. Prices will probably be higher. The alfalfa crop was nearly a failure in many sections and while the crop was good in other places it is not likely there will be enough good seed to supply the demand. Order early.

\section{FANCY IDAHO ALFALFA}

Fancy Idaho is our leader in common alfalfa this vear. The crop was good in that state and the quality of the seed is rery fine. We have a large stock on hand of beautiful, bright, high testing seed and it is almost as hardy as Dakota and Montana seed. We recommend it for northern sowing.

Prices-By mail: Lb., 40c. By freight: Lb., 35c; 1/2 pk., \$2.10; pk., \$4.00; bu., $\$ 15.10 ; 100$ lbs., $\$ 25.00$.

\section{HARDY MONTANA ALFALFA}

Montana Alfalfa has for some years had the reputation of being the hardiest of all strains of common alfalfa. The crop the past season was almost a failure but fortunately we have several carloads of seed carried over from last year. This seed is much better than the new seed as it is plumper and larger. It is all in 60 -pound sealed bags, state certified. Prices-By mail: Lb., 50c. By freight: Lb., $45 \mathrm{c} ; 1 / 2$ pk., $\$ 2.75 ;$ pk., $\$ 5.25 ;$ bu., $\$ 20.20 ; 100$ lbs., $\$ 33.50 ; 500$ lbs. at $\$ 33.00$. 60-pound sacks extra at

\section{HARDY DAKOTA ALFALFA}

The crop was practically a failure and we have none to offer. Order Hardy Montana instead. FANCY UTAH ALFALFA

Utah is the big alfalfa seed producing state. In fact Utah grows about as much seed as all other states combined. Usually called "Hardy Northwestern." It is good seed but not as hardy as Idaho seed.

Prices-By mail: Lb., 40c. By freight: Lb., 35c; $1 / 2$ pk., $\$ 2.00 ;$ pk., $\$ 3.85 ;$ bu., $\$ 14.50 ; 1001 b s ., \$ 24.00$.

\section{FANCY KANSAS ALFALFA}

Kansas Alfalfa has proven hardier at the Wisconsin Experiment Station than Utah seed. Crop light.

Prices: Same as for Fancy Utah.

Ask for a copy of Wisconsin Bulletin No. 374, "Wisconsin's Opportunity with Alfalfa."

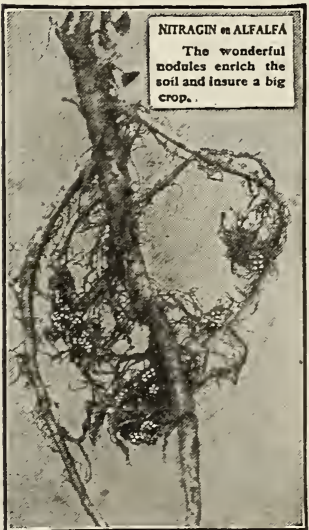

Inoculated Alfalfa Roots.

\section{INOCULATE WITH NITRAGIN}

Alfalfa, Sweet Clover, All Clovers, Soy Beans, Vetch, Peas, Beans, and all other legumes should always be inoculated. The lack of necessary bacteria in the soil is often the cause of a poor crop or a total failure. PRICES OF NITRAGIN.

For all legumes except Soy Beans, Garden Peas and Beans:

$1 / 4$ bu. size, inoculates 15 lbs. seed, $40 \mathrm{c}$; by mail, $45 \mathrm{c}$. $1 / 2$ bu. size, inoculates $30 \mathrm{lbs}$. seed, $60 \mathrm{c}$; by mail, $65 \mathrm{c}$. 1 bu. size, inoculates $60 \mathrm{lbs}$. seed, $\$ 1.00$; by mail, $\$ 1.05$.

5 bu. size, inoculates 300 lbs. seed, $\$ 4.75$; by mail, $\$ 4.95$. Important: When ordering always name the seed you ish to inoculate.

The same inoculation can be used for both Alfalfa and Sweet Clover.

PRICES GREATLY REDUCED FOR SOY BEANS.

/ bu. size, inoculates $30 \mathrm{lbs}$. Soy Beans, 40c; by mail, $45 \mathrm{c}$.

1 bu. size, inoculates $60 \mathrm{lbs}$. Soy Beans, 70c; by mail, $75 \mathrm{c}$.

5 bu. size, inoculatés 300 lbs. Soy Beans, $\$ 2.50$; by mail, $\$ 2.70$

NITRAGIN FOR PEAS, SWEET PEAS AND BEANS.

Garden size package, 20c; by mail, 22c.

Inoculates up to 8 pounds of seed.

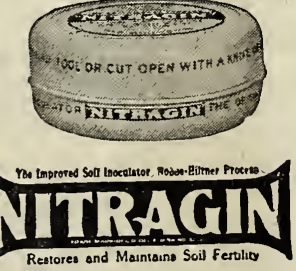

Nitragin is an old reliable inoculator. It is well known and used by many agricultural colleges. Sold in tins-not glass-packed in a rich, soil-like granular medium, easy to mix with seed. Contents always fresh and bacteria active and vigorous. 


\section{GRIMM, THE EXTRA HARDY ALFALFA}

Grimm Alfalfa is the hardiest of all alfalfa. The seed costs more, but it pays to use it to insure against winter killing when the unfavorable season comes.

Grimm may usually, not always, be distinguised from Common Alfalfa-

First, by the fact that the blossoms are variegated in color, yellow, green, blue, brown, instead of all purple.

Second, by its branching root system instead of the long, straight tap root of the common alfalfa. This enables it to withstand the hard winters, the tap root of the common alfalfa often being broken by heary freezing.

Grimm is the safest alfalfa seed to sow and the Experiment Stations recommend it. The important thing in buying Grimm Alfalfa is to make sure that it is genuine Grimm and no doubt considerable seed has been sold for Grimm in the past that was not Grimm.

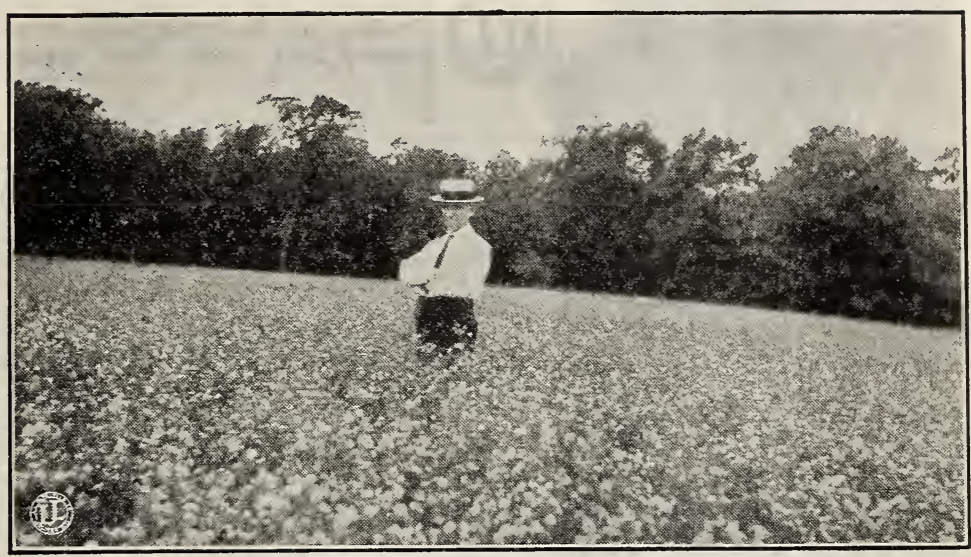

Field of Grimm Alfalfa in Wisconsin. Farm of Swartz Bros.

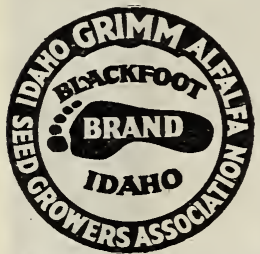

\section{BLACKFOOT IDAHO GRIMM}

The Blackfoot Brand of Grimm Alfalfa is a specially choice strain of Grimm grown by an Association of Idaho Farmers who have absolutely genuine seed and who have all their fields inspected and the seed certified and sealed by the State Seed Analyst. These growers can all positively trace the origin of their seed back to the original Grimm stock of Carrer County, Minnesota. The seed is thoroughly cleaned and scarified and put up in sealed bags, 30 and 60 pounds each, and sold as "Idaho State Certified Grimm Alfalfa, Blackfoot Brand," guaranteed absolutely free of dodder and all other noxious weeds.

We believe this "Blackfoot Grimm" is the purest and best strain of Grimm on the market and it is absolutely reliable. We have secured a very large stock of it for our customers. Remember, the state of Idaho is back of this seed and guarantees its genuineness. The state where the seed is grown is not so important so long as it is northern grown, but the genuineness of the seed is the essential thing.

There are two grades of the Blackfoot Grimm Alfalfa, "Grade No. 1" or "Red Tag" which must show a purity test of 99 per cent or over, be dodder free and free from other noxious weeds, but may contain a trace of sweet clover, and "Grade Extra No. 1" or "Blue Tag," which must test 99.5 per cent purity with no sweet clover.

PRICES OF BLACKFOOT GRIMM FOR 1928.

Grade No. 1. By mail: Lb., 60c. By freight: Lb., 55c; 1/2 pk., $\$ 3.35 ;$ pk., $\$ 6.50 ;$ bu., $\$ 25.00 ; 100$ lbs., $\$ 41.50$; 500 lbs. at $\$ 41.00$. Sacks free.

Grade Extra No. 1: $1 / 2$ pk., $\$ 3.50$; pk., $\$ 6.75$; bu., $\$ 25.90 ; 100$ lbs., $\$ 43.00 ; 500$ lbs. at $\$ 42.50$. Sacks free.

\section{IDAHO STATE CERTIFIED GRIMM}

We have another stock of very fine Grimm Alfalfa to offer this year that is also Idaho grown. This stock we call simply "Idaho State Certified Grimm." "It does not have quite the reputation that the Blackfoot Grimm has but it is a little lower in price and nearly if not quite as good. It is "State Certified," put up in sealed 60-pound bags. Our stock is the "Red Tag" Grade and just as high in purity as the Red Tag Blackfoot.

Prices: By mail: Lb., 60c. By freight: Lb., 55c; 1/2 pk., \$3.25; pk., \$6.35; bu., \$24.40; 100 lbs., $\$ 40.50$; $500 \mathrm{lbs}$. at $\$ 40.00$. 60-pound bags extra at $20 \mathrm{c}$.

\section{CANADIAN VARIEGATED ALFALFA}

Canadian Variegated Alfalfa is a specially hardy strain of alfalfa grown in Northern Ontario. It is usually classed with the Grimms. The crop in Canada was nearly a failure the past season and what little seed we have was carried over.

Prices, 'while it lasts: Pk., \$5.75; bu., $\$ 22.30 ; 100$ lbs., $\$ 37.00 ; 500$ lbs., at $\$ 36.50$.

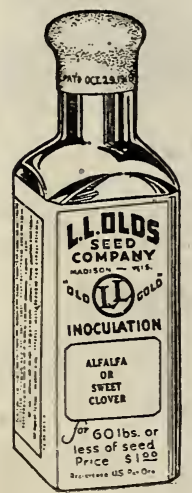

\section{OLD GOLD INOCULATION}

\section{A PURE CULTURE JELLY FORM OF INOCULATION.}

We have handled Nitragin for many years and it seems to have given entire satisfaction. We have it again this year. See page 4. As some prefer the jelly form of culture, however, we offer it that way, calling it "Old Gold Inoculation."

Old Gold Inoculation is a scientific pure culture of root nodule bacteria, prepared on special food jelly in bottles with patent stoppers which permit the bacteria to live and breathe and maintain their vigor. Each culture contains plenty of bacteria to inoculate the quantity of seed marked on the bottle. The cost per acre is very small.

The Legume crops when not inoculated rob the soil; inoculated with the right bacteria, they feed the soil, grow more vigorously and contain a higher percentage of valuable feed proteins.

Old Gold Inoculation is the easiest inoculation to use, requiring no equipment, or experience. Takes only a few minutes. Complete directions on every bottle. Results are sure.

\section{PRICES OF OLD GOLD INOCULATION.}

For Alfalfa, Sweet Clover, Red Clover and other Clovers (specify which): 1/2 bu. size, 60c; by mail, $65 \mathrm{c}$; 1 bu. size $\$ 1.00$; by mail, $\$ 1.05$. (Same culture is used for Alfalfa and Sweet Clover.)

For Soy Beans, Field Peas and Vetches (specify which): 1 bu. size, 50c; by mail, 55c; 5 bu. size, $\$ 2.00$; by mail, $\$ 2.20$.

For Garden Peas, Sweet Peas and Garden Beans combined: Garden size, 25c; by mail, 27c.

(Always specify name of crop as well as size of culture wanted.) 


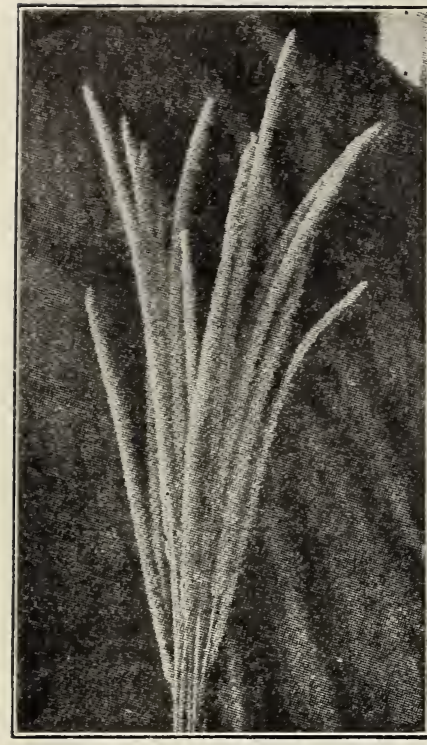

Olds' High Grade Timothy Grows Long Heads.

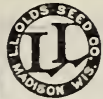

Wisconsin grows wonderfully fine Timothy and Recleaned High Grade Timothy seed is one of our specialties. We sell many carloads every year. Prices this year are way low as com. pared with other items. The market has recently been firming up a little, however, and it looks as if prices would be higher. The price certainly cannot go any lower.

Prices, Superb Brand, by mail: Lb., 25c. By freight: Lb., $20 \mathrm{c}$; $1 / 2$ pk., $40 \mathrm{c}$; pk., $75 \mathrm{c}$; bu. (45 lbs.), $\$ 2.65 ; 100 \mathrm{lbs}$., $\$ 5.75 ; 500 \mathrm{lbs}$. at $\$ 5.60$. Bags extra at $35 \mathrm{c}$.

Old Gold Brand: Bu., \$2.55; 100 lbs., \$5.50; $500 \mathrm{lbs}$. at $\$ 5.35$

TIMOTHY AND ALSIKE MIXED. (1-5 Alsike): $\mathrm{Pk}$., $\$ 1.40$; bu. (45 lbs.), $\$ 5.25$; 100 lbs., $\$ 11.50 ; 500$ lbs, at $\$ 11.25$.

Timothy prices are good until Feb. 1st only. Ask for "Weekly Price List" after that.

\section{OLDS' FANCY RED TOP.}

RED TOP is a very valuable general purpose grass. A good meadow grass, one 01 the best for pasture and splendid for lawns. Red Top is very low in price, about half what it was last year. Sow it liberally.

Fancy solid Seed. (Recleaned, free from chaff.) By mail: Lb., 35c; 3 lbs., 95c. By freight: Lb., 30c; 10 lbs., \$2.25; 100 lbs., $\$ 17.00 ; 500 \mathrm{lbs}$. at $\$ 16.50$. Bags extra at $35 \mathrm{c}$. Unhulled Red Top. By freight: Lb., 25c; 10 lbs., \$1.75; 100 lbs., \$11.50.

\section{LIGHT GRASSES.}

Prices of all the following grasses include sacks. While prices may change in some instances they will probably stand as given here for the season. Ask for special prices in large quantities. We handle only the best grades.

KENTUCKY BLUE GRASS (Fancy). Also known as June Grass. Well suited for pasture, and the standard lawn grass. The seed we offer is the best that can be secured, 21 pound seed. Prices very low, owing to large crop. By mail: Lb., 45c; 3 lbs., $\$ 1.20$. By freight: Lb., 40 c; 10 lbs., $\$ 3.00$; 100 lbs., $\$ 24.00$.

(We also have 19 pound seed that we can furnish at $\$ 1.25$ per hundred less.)

ENGLISH or PERENNIAL RYE GRASS. The Timothy of England. Does well also in this country. Good for both pastures and meadows. By mail: Lb., $30 \mathrm{c} ; 3$ lbs., $80 \mathrm{c}$. By freight: Lb., $25 \mathrm{c} ; 10 \mathrm{lbs}$., $\$ 2.00 ; 100 \mathrm{lbs}$., $\$ 17.00$.

ITALIAN RYE GRASS. Similar to the preceding but larger and stronger in growth. By mail: Lb., 30c; 3 lbs., 80c. By freight: Lb., 25c; 10 lbs., $\$ 1.85 ; 100$ lbs., $\$ 16.50$.

PACEY'S RYE GRASS. Similar to English Rye Grass, but smaller and more dwarf. By mail: Lb., 30c; 3 lbs., 80c. By freight: Lb., 25c; 10 lbs., $\$ 2.10 ; 100$ lbs., $\$ 18.50$. AMERICAN RYE GRASS. Grown in the state of Washington. Much cheaper than the European grown rye grass. By freight: Lb., 25c; $10 \mathrm{lbs} . \$ 1.50 ; 100 \mathrm{lbs} ., \$ 12.50$.

BROME GRASS (Bromus Inermis). Yields enormous quantities of hay. Defies drought, and not affected by frost. Splendid for a permanent grass. By mail: Lb., 30c; 3 lbs., $75 \mathrm{c}$. By freight: Lb., 25c; 5 lbs., 90c; 10 lbs., $\$ 1.50 ; 100$ lbs., $\$ 12.00 ; 500$ lbs. at $\$ 11.50$.

ORCHARD GRASS. Withstands drought and will grow in the shade .By mail: Lb., 35c; 3 lbs., 90c. By freight: Lb., 30c; $10 \mathrm{lbs} ., \$ 2.50 ; 100 \mathrm{lbs} ., \$ 21.00 ; 500 \mathrm{lbs}$. at $\$ 20.50$. CREEPING BENT. Genuine mixed Bent Grass from South Germany. Much sought after for golf courses. Lb., $\$ 1.10 ; 10 \mathrm{lbs}$., $\$ 10.00 ; 100 \mathrm{lbs}$., $\$ 90.00$.

RED OR CREEPING FESCUE. For lawns and golf grounds. Displaced by Chewings' escue, which is a true Red Fescue.

CHEWINGS' FESCUE. A very fine pure strain of Fescue, selected by a man named Chewings. Grown in New Zealand. By freight: Lb., 45c; 10 lbs., $\$ 4.00 ; 100$ lbs., $\$ 35.00$. ROUGH STALKED MEADOW. By freight: Lb., 55c; 10 lbs., $\$ 5.00 ; 100$ lbs., $\$ 45.00$.

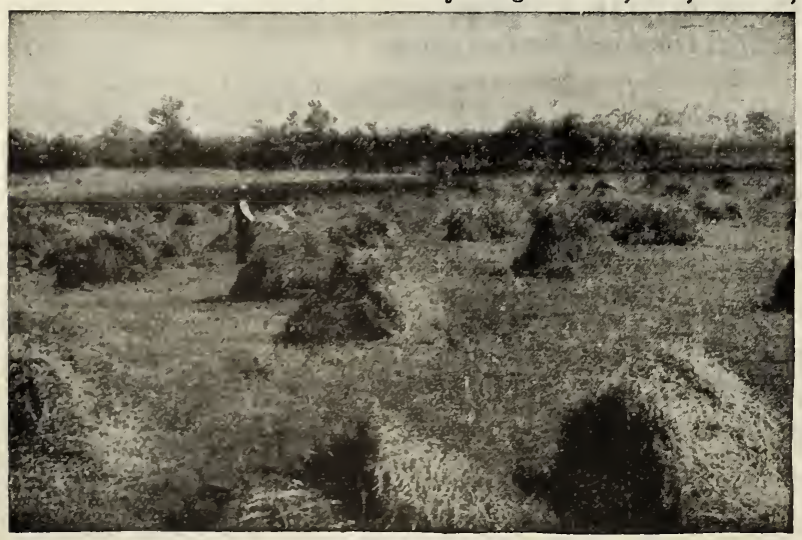

T A I I MEADOW OAT GRASS. For dry soils. By freight: Ib., $40 \mathrm{c} ; 10$ lbs., $\$ 3.50 ; 100$ lbs., $\$ 30.00$.

\section{OLDS' PASTURE MIXTURE.}

Olds' Pasture Mixture is made up of the best T grades of Orchard Grass, Red Top, Timothy, Blue Grass and others. Prices very low. By freight: Lb., 30c; 10 lbs., \$2.00; 100 lbs., $\$ 16.00 ; 500 \mathrm{lbs}$. at $\$ 15.50$.

\section{OLDS' MEADOW MIXTURE.}

For a permanent stand of grass to be cut O for hay. It consists of the same grasses as used in our Pasture Mixture, but in different proportions, the Blue Grass being left out. By freight: Lb., 30c; 10 lbs., $\$ 2.00 ; 100$ lbs., $\$ 15.00 ; 500 \mathrm{lbs}$. at $\$ 14.50$.

If seed is ordered sent by mail at the freight prices, add sufficient to cover postage. 


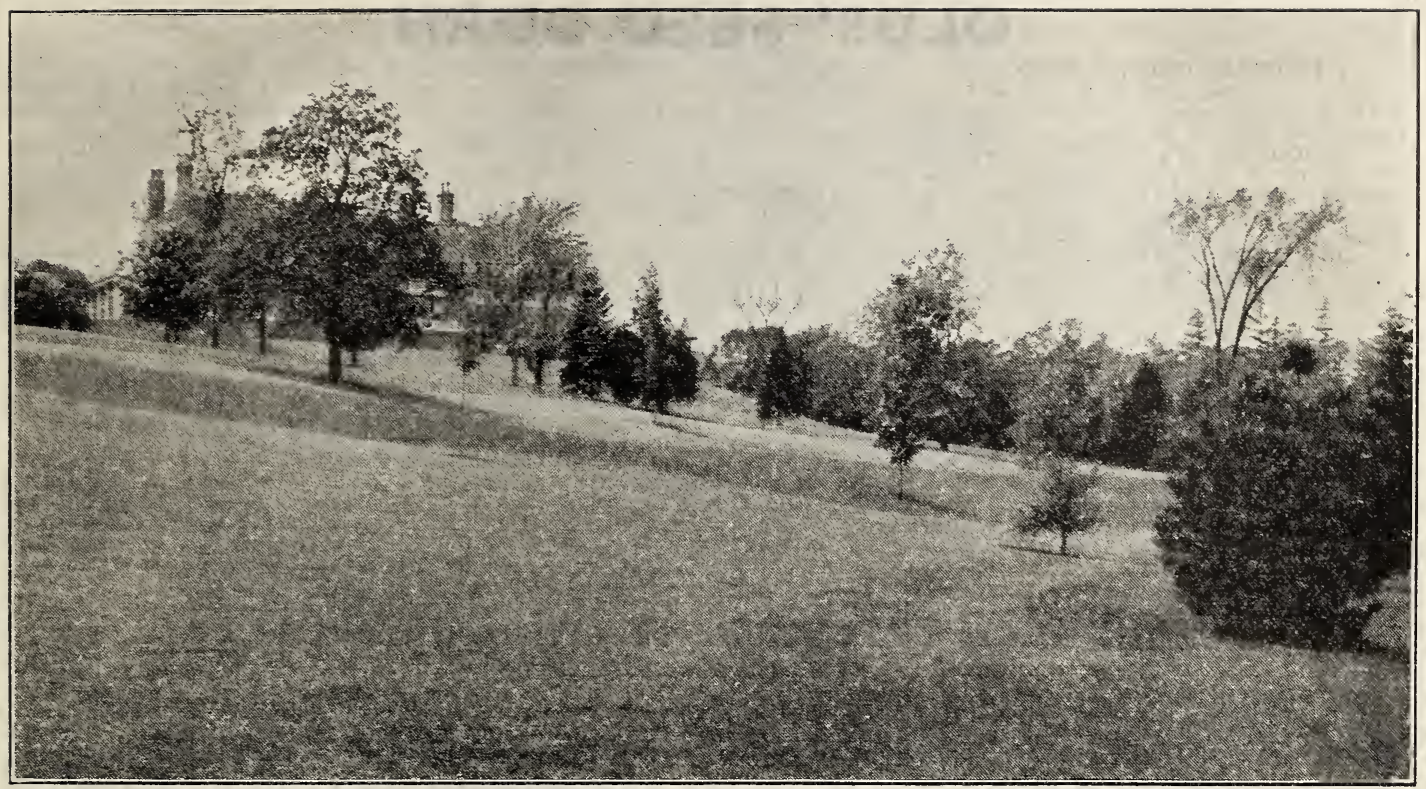

Olds' Madison Parks Lawn Grass Makes an Even Velvety Lawn.

\section{OLDS’ LAWN GRASS.}

We offer four very fine mixtures of High Grade Lawn Grass varying in price according to the amount of highest priced seed used. None of them contain timothy and none are cheap mixtures. Our customers do not want the sort of worthless stufi that is offered in packages at many of the stores throughout the country. Prices low this year.

CULTURE. Sow Lawn Grass at the rate of one pound for each 300 square feet, or not less than 100 pounds per acre. Early spring is the best time for sowing although lawn grass may be sown most any time when the ground can be worked. Have the soil thoroughly prepared. Use "Vigoro" for fertilizer or Pulverized Sheep Manure or Bone Meal. Every lawn, new or old, needs fertilizer. Many lawns need lime also. See page 92.

"THE BEAUTIFUL LAWN," a 20-page illustrated book by Profs. Moore and Aust of the University of Wiscon. sin. Part I, "Making the Lawn," covers the matters of soil, seed, methods of seeding, etc. Part II, "Care of the Lawn," takes up mowing, fertilizing, weeds and their control, etc. Price, 10c postpaid, or free on request with every lawn grass order.

\section{OLDS' MADISON PARKS LAWN GRASS.}

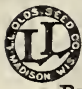

Olds' Madison Parks Lawn Grass is a very carefully prepared mixture of high grade, heavy seed, that has been used extensively for several years in the parks about Madison. The seed is composed of White Dutch Clover, Creeping Bent, Chewings' Fescue, Fancy Red Top, Fancy Kentucky Blue Grass and others mixed in proper pro portions. We recommend Madison Parks Lawn Grass as our best lawn mixture.

By mail: Lb., 55c; 3 lbs., \$1.55. By freight: Lb., 50c; 5 lbs., \$2.25; 10 lbs., $\$ 4.00 ; 1001 b s ., \$ 35.00$.

\section{OLDS' CAPITAL LAWN GRASS.}

Olds' Capital Lawn Grass is made up of substantially the same grasses and the same grades of seed that were D used to make the beautiful lawn surrounding Wisconsin's magnificent Capitol building here at Madison. It 15 composed of heary seed of the highest germination but contains no White Clover. We recommend it By mail: Lb., $50 \mathrm{c} ; 3 \mathrm{lbs}, \$ 1.40$. By freight: $45 \mathrm{c}$; 5 lbs., $\$ 2.00 ; 10 \mathrm{lbs}$., $\$ 3.50 ; 100 \mathrm{lbs}$., $\$ 30.00$.

\section{OLDS’ OLD GOLD LAWN GRASS.}

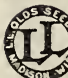

Olds' Old Gold Iawn Grass is a good mixture at a low price. We have been making it for years tomers. This mixture will probabty to our cus ter showing the first year than any of the others.

By mail: Lb., 45c; 3 lbs., \$1.25. By freight: Lb., $40 \mathrm{c}$; 5 lbs., $\$ 1.75 ; 10$ lbs., $\$ 3.00 ; 100 \mathrm{lbs}$., $\$ 25.00$.

\section{OLDS' SHADY PLACE LAWN GRASS.}

(II)

For sowing under large trees and in other deeply shaded places where ordinary grasses do not suc ceed well. It is made up largely of rare and high-priced grasses such as Chewings Fescue, Creeping Bent, Rough Stalked Meadow, etc.

By mail: Lb., 60c; 3 lbs., $\$ 1.70$. By freight:

$55 \mathrm{c} ; 5$ lbs., $\$ 2.50$; 10 lbs., $\$ 4.50 ; 100$ lbs., $\$ 40.00$.

(All Lawn Grass prices include sacks. "We use only the best grades of seed.)

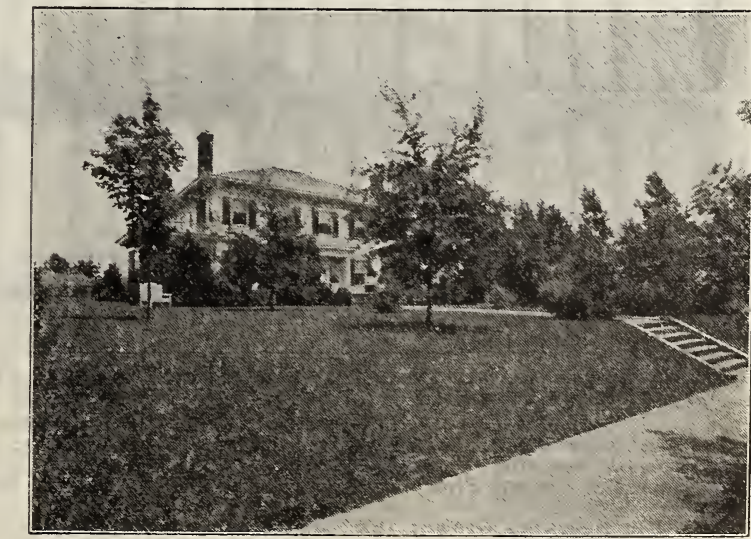

Good Seed and "Vigoro" Made This Lawn. 


\section{OLDS' SEED CORN}

WISCONSIN GROWN SEED CORN. Our big specialty is Fire-Dried Wisconsin Grown Seed Corn. We have other seed corn to ofier, lots of it and some of our Nebraska grown corn, namely that grown the First Year from Wisconsin Seed, is almost equal to Wisconsin grown. See what we say about it on page ten. But our best corn is Wisconsin grown and that is the kind we would like to see our customers buy if the seed is wanted primarily for ear corn.

WISCONSIN VARIETIES BEST. Our principal varieties of corn are the ones originated and dereloped here at the Wisconsin Experiment Station during recent years and the ones recommended by them. These rarieties, because adapted to our conditions, have put Wisconsin on the map as a corn-growing state until now in average yield of corn per acre over a term of years we are ahead of Illinois, Iowa, Missouri, Indiana and Ohio, all so-called Corn Belt

states. This is a great triumph for Wisconsin.
OUR CORN GROWN BY SPECIALISTS. We have associated with us during the last few years a group of expert corn men in different parts of the state who grow the different varieties for us. These men understand the breeding and selecting of corn, as well as the handling and drying. All our Wisconsin corn is fire-dried, most of it dried in regular corn-drring houses and it is all from select ears. The corn is either tipped before shelling or thoroughly graded after shelling and much of it graded with Hero Corn Graders. See page 89. This year the corn is not as nice in appearance as usual cwing to the fact that more drying was required than ordinarily. The corn is all high in germination, howerer, and has the breeding.

OUR GUARANTEE. Note what we say about guaranteeing quality on page one. This applies to corn, as well as other things. The stock must be as represented. We guarantee, however, only to the extent of the amount paid us and will not be responsible for the crop.

SEED CORN PRICES. The prices giren in this catalog will hold until February 1 st only.

Early in the fall it looked as if there would be plenty of Wisconsin grown seed corn. However, as our catalog goes to press, Dec. 15th, the situation is not so good. Reports from sereral of our best growers are disappointing and original estimates of delicery are considerably cut down. We really doubt now if there is much more good Wisconsin seed corn in sight than there was last year at this time. Last year every bushel was wanted and prices were adranced after February 1st. We are starting our prices lower this sear than last, but it looks as if they would surely have to be advanced later, with almost a certainty that the best stocks will be exhausted before corn planting time.

\section{MURDOCK YELLOW DENT. (Wisconsin No. 13.) \\ Sweepstakes Corn of the Northern Zone.}

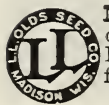

Murdock Yellow Dent is our farorite variety of corn. It was awarded sweepstakes for the Northern Zone, comprising the states of Wisconsin, Michigan, Minnesota, North Dakota and South Dakota, at the National Corn Expositions of 1909 and 1910 , and this in competition with corn of all varieties. Mr. H. C. Brueckner of Jefferson County, Wisconsin, was the exhibitor of this corn. He took more than 35 premiums on it in 12 Jears. lightly rough and very uniform in type. It makes a large heavy growth of stalk and leaf and so is a good silage variety. As to season, it is decidedly early and perfectly safe to plant as far north as the geographical center of Wis. consin. It is a fine extra early also for Illinois, Iowa and other cornbelt states. Earlier than Silver King and equal to it in yield.

BRUECKNER MURDOCK. We handled Mr. Brueckner's Murdock. Yellow Dent for 13 consecutive years up to the time of his death in 1922, and he was selecting and further improving the corn each year during all that time. Since his death his two sons, Justus and Leo, have continued the work of developing and improving, using their father's methods. All our Brueckner Mrurdock this year was grown by Leo Brueckner; Justus' crop haring failed.

The Brueckners have taken many prizes at State and National shows. In 1925 Leo Brueckner permanently won the Hoard's Dairyman cup, first offered in 1915 for the best 10 ears of yellow corn at the Wisconsin State Grain Show. At the last State Grain Show, Leo Brueckner was given first place for the "Best 10 Ears Yellow Dent," and also "Sweepstakes for 50 Ears." The ear of Jurdock on our front cover was grown by him this past season.

Our other Wisconsin grown Murdock is fire-dried and choice and most of it from Brueckner seed originally.

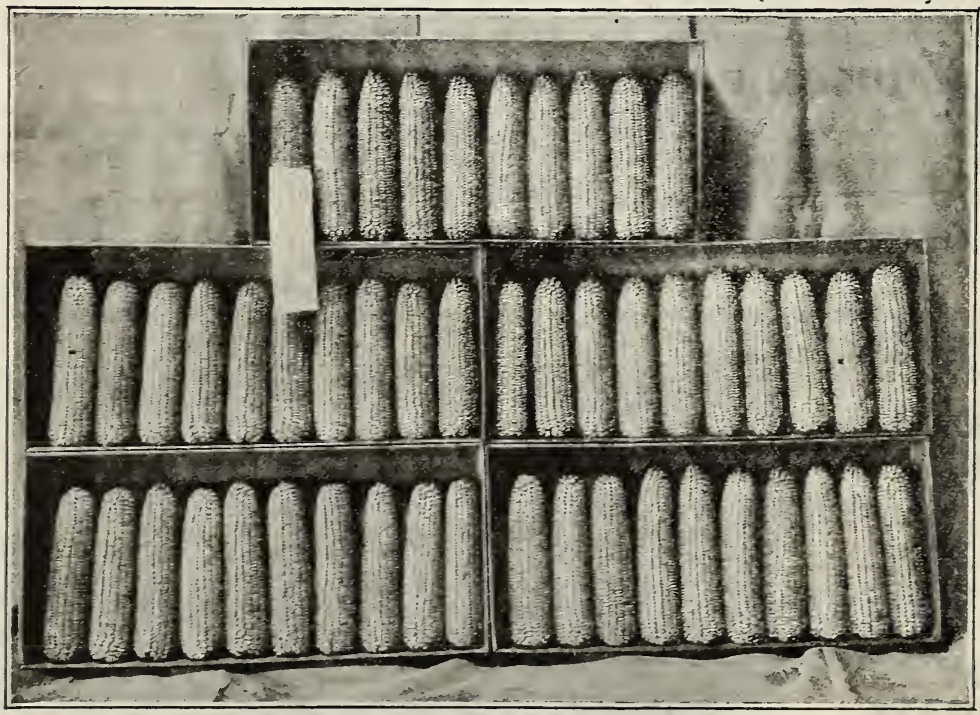

Brueckner Murdock. The 50-Ear Sample that Won First Prize at the 1920 Wisconsin Pure Bred Grain Show. Exhibited by Mr. H. C. Bruckner.
NEBRASKA GROWN CORN.

We offer Nebraska grown stock of most of the Wisconsin varieties and we have a good lot of it. This stock will certainly be all right to plant for silage and the "'First year from Wisconsin Seed," that is, grown from seed that was raised in Wisconsin in 1926. will be pretty fairly safe to plant for general field crop.

Note the record for maturity that this corn made at the Wisconsin Experiment Station as shown on page 1.0. All the First Year From Wisconsin Seed Mur. dock that we have to offer this year was grown from Brueckner seed by some well known seed corn growers of Eastern Nebraska. They wrote regarding the crop under date of Nov. 30, 1927, as follows: "The Silver King and Iurdock we can not recommend too highly. They seem to be fully as early as any stocks of these varieties that we have had, and in addition they gave wonderfully satisfactory yields. We have some type ears of these kinds from the Wisconsin Experiment Station, and we think that your stocks, in the main, follow these closely.'

We have a good supply of this particular lot and it is certainly good seed. We recommend it with great confidence.

PRICES OF MURDOCK YELLOW DENT FOR 1928.

Brueckner Stock: $1 / 2 \mathrm{pk}$., $\$ 1.30 ;$ pk. $\$ 2.40 ;$ bu. $\$ 7.50 ; 21 / 2$ bus. at $\$ 7.40 ; 10$ bus. at $\$ 7.25$. Bags extra at $35 \mathrm{c}$. Other Wisconsin: $1 / 2$ pk., $\$ 1.10 ;$ pk., $\$ 2.00 ;$ bu., $\$ 6.00 ; 21 / 2$ bus. at $\$ 5.90 ; 10$ bus. at $\$ 5.75$. 11 bus. at $\$ 3.90 ; 10$ Nebraska Grown, First Year from Brueckner Seed: 1/2 pk., 75c; pk., \$1.30; bu., $\$ 4.00$

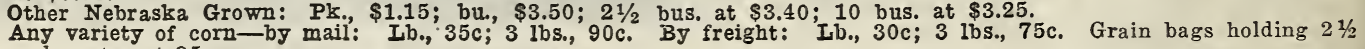
Any variety of corn 


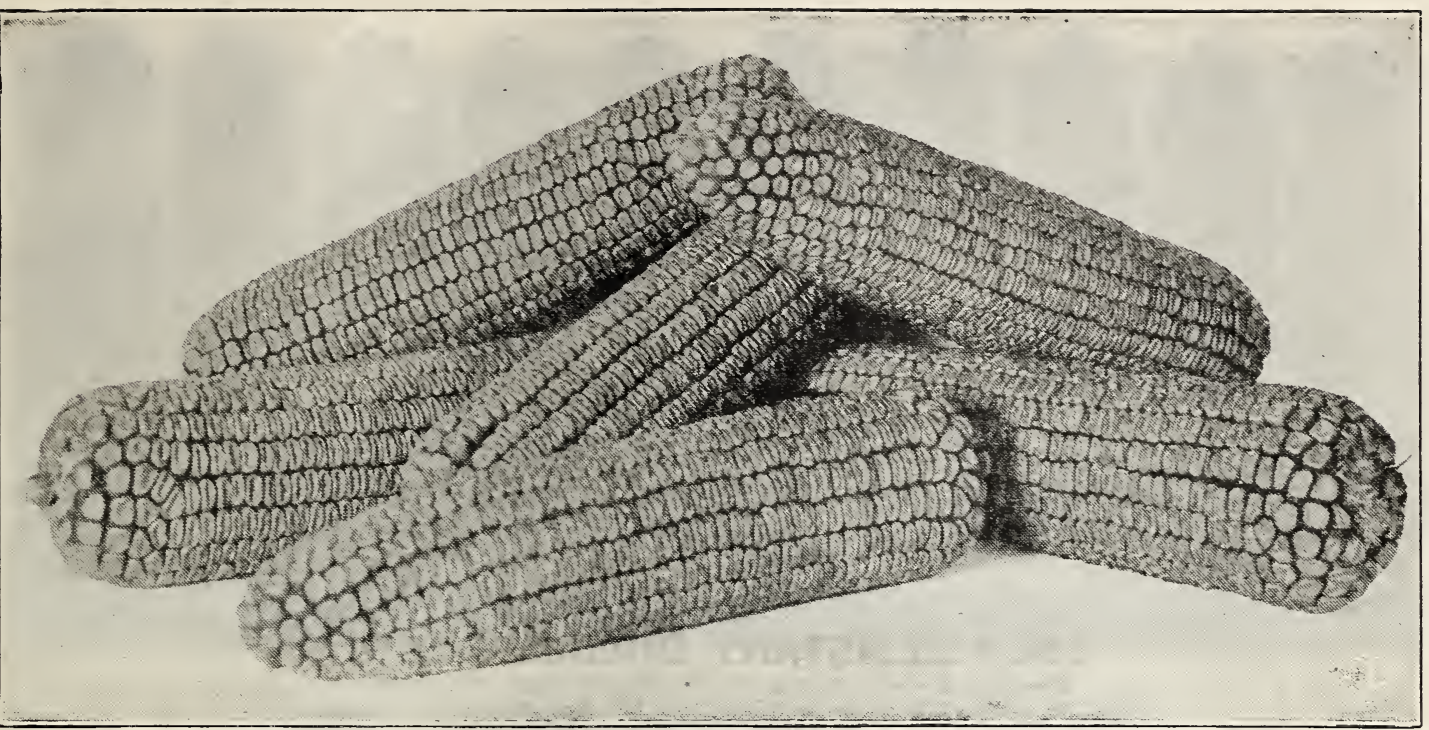

Bishop's Heavy Yield Golden Glow. The Ear of Golden Glow on Our Front Cover is Also a Bishop Ear.

\section{GOLDEN GLOW (Wisconsin No. 12.)}

Most Largely Grown of all Wisconsin Varieties.

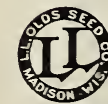

more largely than ans other variety, and in fact, they estimate at the Wisconsin College of Agriculture that half of all the corn grown in the state now is Golden Glow. It certainly is well adapted to all sections of the state as far north as northcentral Wisconsin, and is, of course, equally valuable for other states of about the same latitude. It is a little earlier than either Murdock or Silver King, hence safer in an unfavorable season.

Description. Golden Glow is a cross of Wis. No. 8 and Toole's North Star, the idea being to produce a corn combining the extreme earliness of the former with the larger ears and deeper kernels of the latter. It is a pure golden sellow corn, most attractive in color and appearance. Ears are fairly large, the standard official length being $81 / 4$ to $91 / 4$ inches, stmmetrical in shape, slightly tapering with exceptionally well-filled tips; kernels of good length for such an early corn. It is strictly a Wisconsin corn developed at the Wisconsin Experiment Station.

BISHOP'S HEAVY YIELD GOLDEN GLOW. Te have a specially fine strain of Golden Glow, grown by Mr. W. E. Bishop in Trempealeau County, Western Wisconsin. The Bishop strain is characterized by uniformity of trpe and color, strong vigorous growth, earliness of maturity, and "heavy yield." Mr. Bishop almost always reports a yield of around 100 bushels per acre for his entire acreage.

Mr. Bishop has been growing and improving this "Heavy Yield" strain of Golden Glow for many years. This is the eleventh year that we hare offered it. Last year we had none as his crop failed, but this year he is making delivery again although the amount is smaller than usual. The corn had to be given more drying than ordinarily and as a result the kernels are smaller than usual and shrunken in appearance. The breeding is there, however, and the test is high and the corn is all State Certified.

JACQUES' NORTHERN WISCONSIN GOLDEN GLOW. We have again also a stock of fine Goiden Glow from Mr. W. H. Jacques, of Pierce County, our famous grower of Cold Resistant and Wisconsin No. 25. This stock is also Certified. See what we say about Certified Stock on the next page.

This is an early strain and will be best for our northern customers. Note from page 10 that the Jacques' Golden Glow matured earlier than the average of all other lots of Wisconsin Golden Glow in the State Experiment tests.

OTHER GOLDEN GLOW. We hare a splendid, large stock of other Wisconsin Golden Glow from careful growers also a good stock of Nebraska Golden Glow. The First Year Stock Nebraska is all from Lang strain seed, furnished by us to our Nebraska growers last spring.

Bishop's Heavy Yield: $1 / 2$ pk., $\$ 1.15 ; \mathrm{pk}, \$ 2.15 ;$ bu. $\$ 6.50 ; 21 / 2$ bus, at $\$ 6.40 ; 10$ bus, at $\$ 6.25$.

Jacques' Northern Wisconsin: $1 / 2$ pk., $\$ 1.10 ;$ pk., $\$ 2.00 ;$ bu., $\$ 6.00 ; 21 / 2$ bus. at $\$ 5.90 ; 10$ bus. at $\$ 5.75$.

Other Wisconsin: $1 / 2$ pk., $\$ 1.00 ;$ pk., $\$ 1.90$; bu., $\$ 5.75 ; 21 / 2$ bus. at $\$ 5.65 ; 10$ bus. at $\$ 5.50$.

Nebraska, First Year from Wisconsin Seed: $1 / 2$ pk., $75 \mathrm{c} ; \mathrm{pk}$., $\$ 1.30 ;$ bu., $\$ 4.00 ; 21 / 2$ bus. at $\$ 3.90 ; 10$ bus. at $\$ 3.75$. Other Nebraska Grown: $1 / 2$ pk., 70c; pk., $\$ 1.15$; bu., $\$ 3.50 ; 21 / 2$ bus. at $\$ 3.10 ; 10$ bus. at $\$ 3.25$.

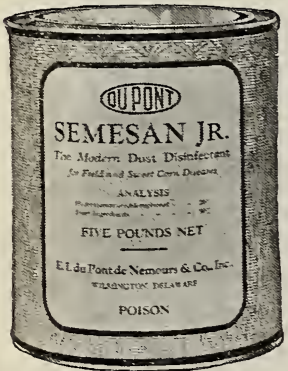

PRICES OF SEMEESAN JR.: 4 OzS., $60 \mathrm{c}$; 1 Ib., \$1.75; 5 lbs., $\$ 8.00 ; 25$ lbs., $\$ 37.50$. (Not mailable.)

\section{TREAT SEED CORN WITH SEMESAN JR.}

Far, Root and Stalk Rots that attack America's corn crop cause an annual loss of $\$ 200,000,000$. These diseases are so destructive that they often destroy from 10 to $50 \%$ of an entire planting. Now, br a simple, inexpensire dusting of seed corn with Semesan Jr. not only are the more prevalent diseases controlled, but substantial yield increases are made possible.

Semesan Jr. Increases Yield. Reports from many agricultural experts and farmers show increased yields from treated seed of $20 \%$ to $40 \%$ or more. In tests conducted in both Illinois and Iowa, Federal and State Governments found that Semesan Jr. not only controlled the diseases but also increased the rields by varying amounts up to $38 \%$.

Semesan Jr. is easily applied to seed corn by the convenient dust. ing method at the rate of 3 ounces to a bushel of seed. Since a bushel will plant from 7 to 8 acres, a pound will treat seed enough to plant 35 to 40 acres at an expense of only 5 cents per acre.

Semesan Jr. pays such large dividends over the insignificant cost of application that it is obviously good sound business to treat all seed corn before planting.

Ask for booklet, "Semesan Jr. Controls Corn Diseases and Increases Yields.,

$$
-9-
$$

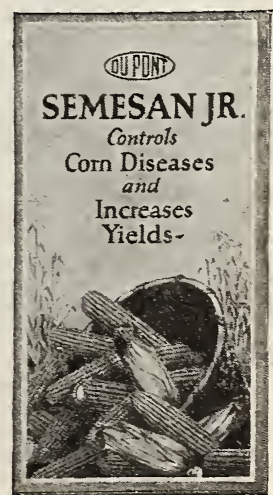




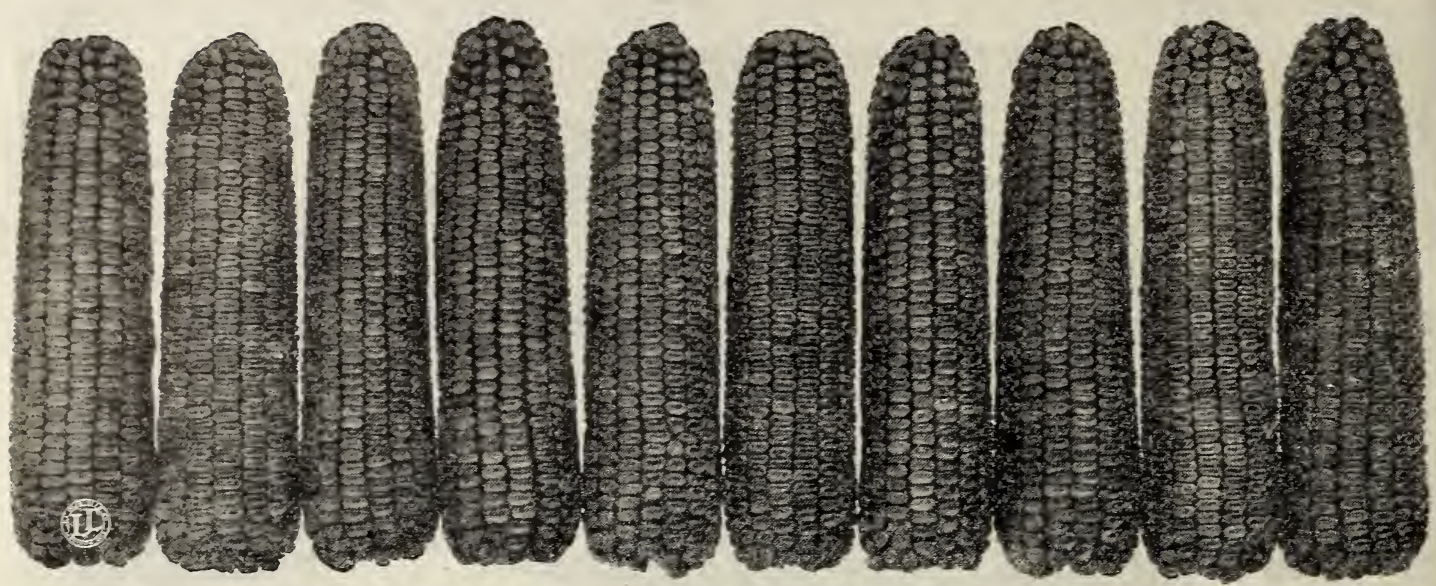

Ten Typical Ears of Olds' Cold Resistant Golden Glow.

\section{COLD RESISTANT GOLDEN GLOW.}

\section{The Best Good-Sized Corn for Central and Upper Wisconsin.}

Also Fine for All Sections to Resist Cold Weather Just After Planting.

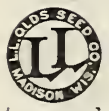

Cold Resistant Golden Glow is a genuine Golden Glow with all the good qualities of that rariety and in addition with the cold resistant features bred into it so it will stand unfavorable weather.

Te offered it for the first time six years ago. It is just what its name indicates, a strain of Golden Glow that will resist the cold unfavorable weather we are so apt to have at corn planting time, and permit of earlier planting. With the idea of producing such a corn and something also that would yield well and ma-

ture early they worked on this at the Wisconsin Experiment Station for ten years testing it out in different sections.

"Owing to the cool weather which frequently presails during the early part of the growing season and retards the growth of corn a strain was bred which will continue to grow under conditions too cool for ordinary rarieties."

"This work was begun in 1914 by germinating six kernels from each of a large number of ears, in an ice box kept at a temperature of $42^{\circ}$ to $45^{\circ} \mathrm{F}$. Those ears, the kernels of which showed any sign of germination, were kept for further breeding. After six years of selection, a strain of Golden Glow corn was produced which will grow at a soil temperature sereral degrees lower than that required for the standard Golden Glow strains. In breeding this strain, every effort was made to maintain the size of the ear and stalk and standard Golden Glow type.

JACQUES COID RESISTANT. Mr. W. H. Jacques, of Pierce County, who has furnished us most of our Cold Resistant during the last two years again has a splendid stock for us. Mr. Jacques, who is a member of the Wisconsin Experiment Association, is one of the leading corn growers of the state He takes great pride in his corn and is constantly improving the strains by selection. The ear of Cold Resistant shown on our front cover is from Mr. Jacques' 1927 crop. Our Jacques corn this year is not as nice in appearance as usual owing to the large amount of drying necessary, but it has the breeding and is fine seed.

CERTIFIED STOCK. All the corn we have from Mr. Jacques this year, all varieties, is Certified. That means that it has been state inspected both in the seed house and in the laboratory, was grown from registered seed, at least 40 rods from any other variety, well cured under proper conditions, is true to type, free from mixture, bright in appearance, and tests at least 95 per cent germination.

Our Other Wisconsin Cold Resistant is also fine corn, was grown by reliable growers, but is not certified.

PRICES OF COLD RESISTANT FOR 1928.

Jacques Stock: $1 / 2$ pk., $\$ 1.15 ;$ pk., $\$ 2.10 ;$ bu., $\$ 6.25 ; 21 / 2$ bus. at $\$ 6.15 ; 10$ bus. at $\$ 6.00$. Bags extra.

Other Wisconsin: $1 / 2$ pk., $\$ 1.10$; pk., $\$ 2.00$; bu., $\$ 6.00 ; 21 / 2$ bus. at $\$ 5.90 ; 10$ bus. at $\$ 5.75$.

Nebraska Grown: $1 / 2$ pk., $70 \mathrm{c}$; pk., $\$ 1.25$; bu., $\$ 3.75 ; 21 / 2$ bus. at $\$ 3.65 ; 10$ bus. at $\$ 3.50$.

\section{COMPARATIVE TESTS AT STATE FARM.}

Careful tests of samples of corn furnished by seedsmen were made the past season at the Wisconsin Experiment Station Farm. These samples included different lots of both Wisconsin and Nebraska grown corn as furnished by five different seed houses together with samples from the Station Farm. The main object of the tests was to determine the comparative earliness of the different strains.

Our Mr. Olds took careful notes in this test field, counting the exact number of mature ears and immature ears of each of the lots of the varieties that we are specially interested in. These notes were taken on two different dates, September 24th and October 8th. The arerage percentages for the two dates of all the mature ears of the Wisconsin varieties were as follows:

Murdock, Brueckner Stock.................. 93\%

Murdock, Tebraska, first vear from Wisconsin seed.. $78 \%$

Murdock, Dther Jebraska Grown, average of 3 lots. 52 \%

Golden Glow, Other Wisconsin Grown, average of 3

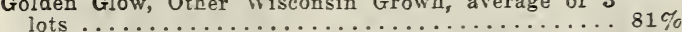

lots
Golden Glow, Tebraska, First Year from Wisconsin
Seed ${ }^{8} \ldots \ldots \ldots \ldots \ldots \ldots \ldots \ldots \ldots \ldots \ldots \ldots \ldots$

Golden Giow, Other Nebraska Grown, one extra early

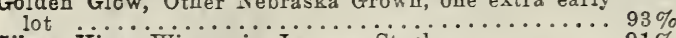

Silver King, Wisconsin Jacques Stock........... $91 \%$

Silver King, Wisconsin Jacques Stock...........

Silver King, Other Wisconsin Grown, average of 3

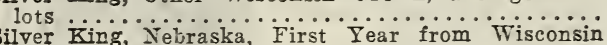
$75 \%$

Silver King, Nebraska, First Year from Wisconsin $77 \%$

Silver King, Other Nebraska Grown, average of 4

Cold Resistant, wisconsin Jacques Stock............. $83 \%$

Cold Resistant, Other Wisconsin Grown, average of

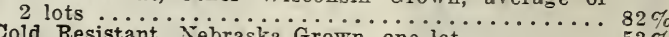

rown, one lot............ $53 \%$

Wisconsin No. 25, Wisconsin Jacques Stock......... $100 \%$ Wiscorsin No. 25, Other Wisconsin Grown, average

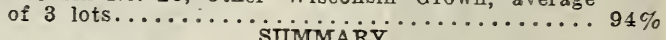

Three Ieading Varieties, Wisconsin Grown, average Three Leading Varieties, Nebraska First Year from $83 \%$ Wisconsin seed, average of all lots........... $80 \%$

Three Leading Varieties, Other Nebraska Grown, av-

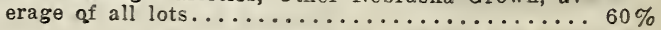

The outstanding and interesting fact from the above is that the average of all our First Year Nebraska Grown Corn is 20 per cent ahead of the average of all the other Nebraska Grown lots of the same varieties and only three per cent behind the Wisconsin Grown corn. Now, we do not say that this corn is just as good as Wisconsin Grown but it would seem from these tests to be nearly as early and is certainly very desirable seed. 


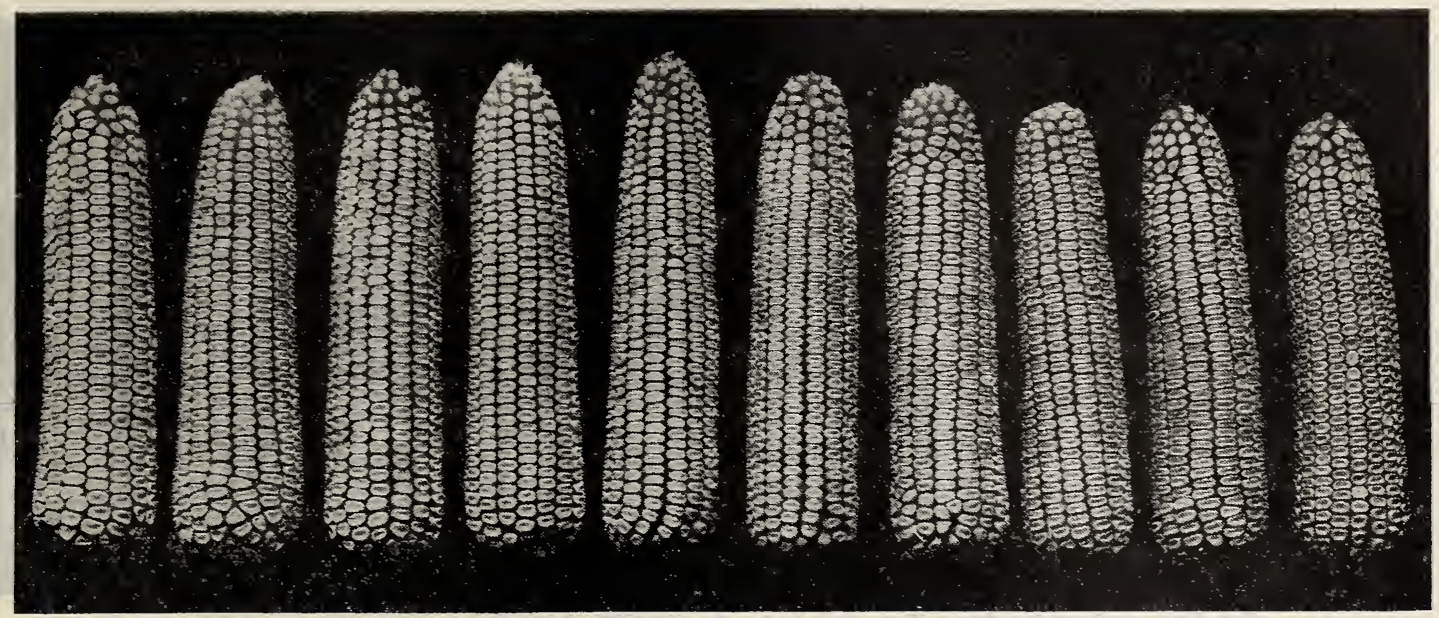

Ten Ears of Wisconsin No. 25, "The Earliest Corn." Grown by W. H. Jacques, Pierce County, Northern Wisconsin.

\section{WISCONSIN NO. 25 (Northern Yellow Dent)}

(11)

All the Wisconsin No. 25 we have to offer this jear was grown by Mr. W. H. Jacques of Pierce County, our famous grower of Cold Resistant. The stock is all Certified. See preceding page for what that means. It is wonderfully fine stock, and not so very small either for such an early variety. Note the size of the ears in the picture at the top of this page and also in the one at the bottom of the page.

We recommend this corn for the extreme northern counties of Wisconsin and for the same latitude in other states. Farther south use Cold Resistant or other Wisconsin varieties. Our Jacques stock of this corn this rear is certainly very fine. We do not see how it could be better for an extra early. The price is necessarily higher than other varieties, as it costs more to grow it. Order early as our stock is rather limited and we expect a great demand for it.

'Jacques' Wisconsin No. 25 was the only lot of corn that showed 100 per cent maturity at the Wisconsin Experiment Station tests of seedsmen's corn the past season. See preceding page.

$1 / 2$ pk., $\$ 1.15 ;$ pk., $\$ 2.15$; bu., $\$ 6.50 ; 21 / 2$ bus. at $\$ 6.40 ; 10$ bus. at $\$ 6.25$.

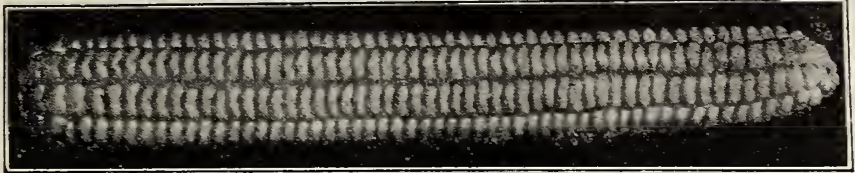

Typical Ear of Improved Smut Nose Flint.

\section{IMPROVED SMUT NOSE FLINT}

Developed, improved and sent out by the Wisconsin Experiment Station. They consider it more prolific than any other Flint and it also has a better stalk. It has a long ear with eight rows of large vellow kernels. Our stock of this variety was grown in Jefferson County, Wisconsin, by Spangler Bros., growers of our best Silver King. It is fire-dried the same as all our other $W$ isconsin corn and is very choice. Prices: $1 / 2$ pk., $\$ 1.15$; pk., $\$ 2.15$; bu. $\$ 6.50 ; 21 / 2$ bus. at $\$ 6.40 ; 10$ bus. at $\$ 6.25$.

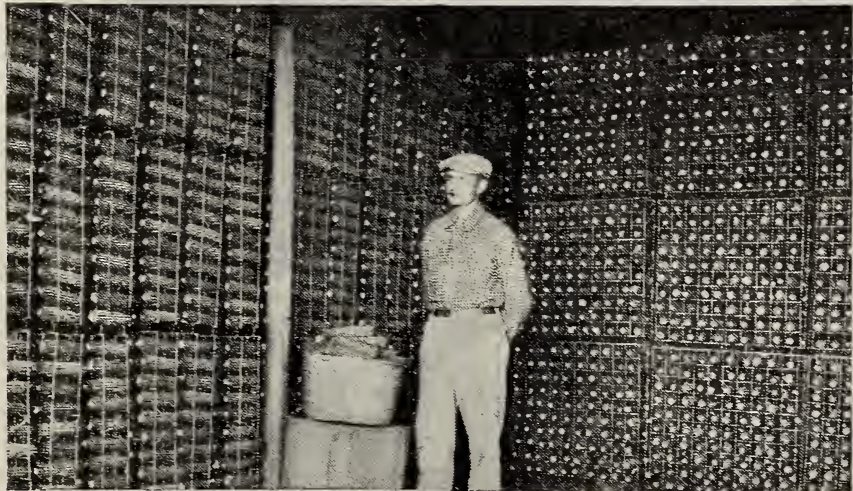

William H. Jacques and His Wisconsin No. 25 Corn, Showing Method of Drying.

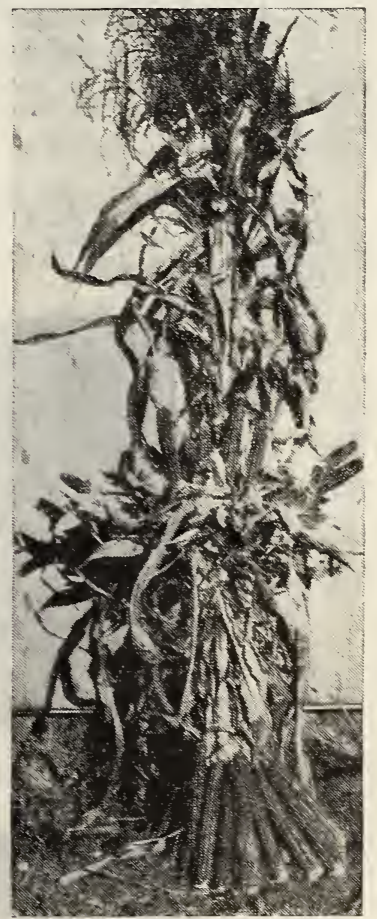

Spangler's Improved Smut Nose Flint. 


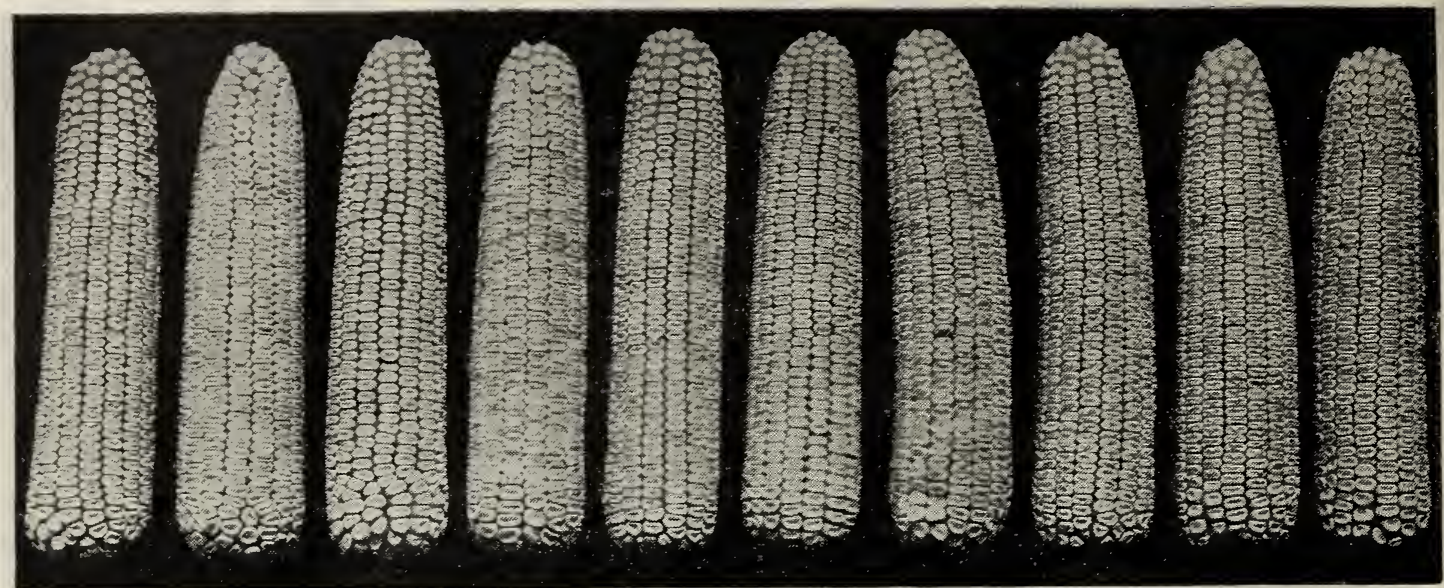

Ten Ears of Spangler Silver King, Grown by Spangler Brothers, Jefferson County, Wisconsin.

\section{SILVER KING (Wisconsin No. 7)}

By Far the Best White Dent for Southern Wisconsin, Northern Illinois and Iowa.

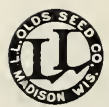

Silver King is not only the best white variety but one of the best and heaviest yielders of all varieties of corn for southern Wisconsin. It came from northern Iowa to Wisconsin in 1904. We first offered it in 1907. Now it is well known and a standard sort. It is a big yielder and wonderfully fine for the silo. The Official Description from Wisconsin College of Agric ulture Corn Bulletin No. 170, is as follows:

This variety is a uniform creamy white in color and has a slight roughness of kernel. The cob is glistening white. The length of ears varies from 7 to 10 inches. The standard length is from $81 / 2$ to $91 / 2$ inches.

"The foundation stock of Silver King was secured from John Banks, Algona, Iowa, by the Wisconsin Experiment Station in 1904. Since that time it has been improred by ear-to-row breeding and adapted to Wisconsin climatic conditions. This variety breeds true to type and is one of the best yielders for crib and silage corn in the southern half of the state. Reports from Experiment Association members show a six year average yield (1918-1923) of 62.1 bushels per acre, an increase of 18.9 bushels above the state average.'

SPANGLER STOCK. Our Spangler Stock of Silver King, shown in the two photographs on this page and also on the front cover, grown by Spangler Brothers, Jefferson. County, is an unusually fine strain, bred to a rather large rough type. The Spanglers have taken many prizes, including "First on Ten Ears'" and "First on Single Ear' at the 1924 State Grain Show, "Sweepstakes on Ten Ears" at the 1925 Show and "Seventh on Single Ear" at the Chicago International, 1923. Also "First on 50 Ears Silver King" and "First on Single Ear" at the last State Grain Show at Antigo. The corn is all Certified.

JACQUES STOCK. Our Jacques Silver King from Mr. W. H. Jacques, of Pierce County, is also very fine and is also Certified. It will be the best to plant anywhere north of Madison because grown so far north.

In fact we feel a good deal of satisfaction over our Jacques Silver King on account of its earliness. In the State test the past season this corn showed 91 per cent maturity, 16 per cent ahead of other Wisconsin Silver King and higher than any Wisconsin Golden Glow or Cold Resistant. This shows that Jacques Silver King must be Very Early. NEBRASKA SILVER KING. Note again, page 10, that our Nebraska Silver King, First Year from Wisconsin Seed, showed up even earlier in the state tests than most of the Wisconsin lots. This is quite remarkable and a great recommendation for this stock. All the "First Year" Silver King that we offer this year is from the Spangler strain. PRICES OF SIIVER KING FOR 1928.

Spangler Stock: $1 / 2$ pk., $\$ 1.15$; pk., $\$ 2.15$; bu., $\$ 6.50 ; 21 / 2$ bus. at $\$ 6.40 ; 10$ bus. at $\$ 6.25$. Bags at $35 \mathrm{c}$ each. Jacques Stock: $1 / 2$ pk., $\$ 1.10$; pk., $\$ 2.10$; bu., $\$ 6.25 ; 21 / 2$ bus. at $\$ 6.15 ; 10$ bus. at $\$ 6.00$.

Other Wisconsin Grown: $1 / 2$ pk., $\$ 1.10$; pk., $\$ 2.00 ;$ bu., $\$ 6.00 ; 21 / 2$ bus. at $\$ 5.90 ; 10$ bus. at $\$ 5.75$.

Nebraska, First Year from Spangler Seed: $1 / 2$ pk., $75 \mathrm{c} ; \mathrm{pk}$., $\$ 1.30 ;$ bu., $\$ 4.00 ; 21 / 2$ bus. at $\$ 3.90 ; 10$ bus. at $\$ 3.75$. Other Nebraska Grown: $1 / 2$ pk., 70c; pk., $\$ 1.15$; bu., $\$ 350 ; 21 / 2$ bus. at $\$ 3.35 ; 10$ bus. at $\$ 3.25$.

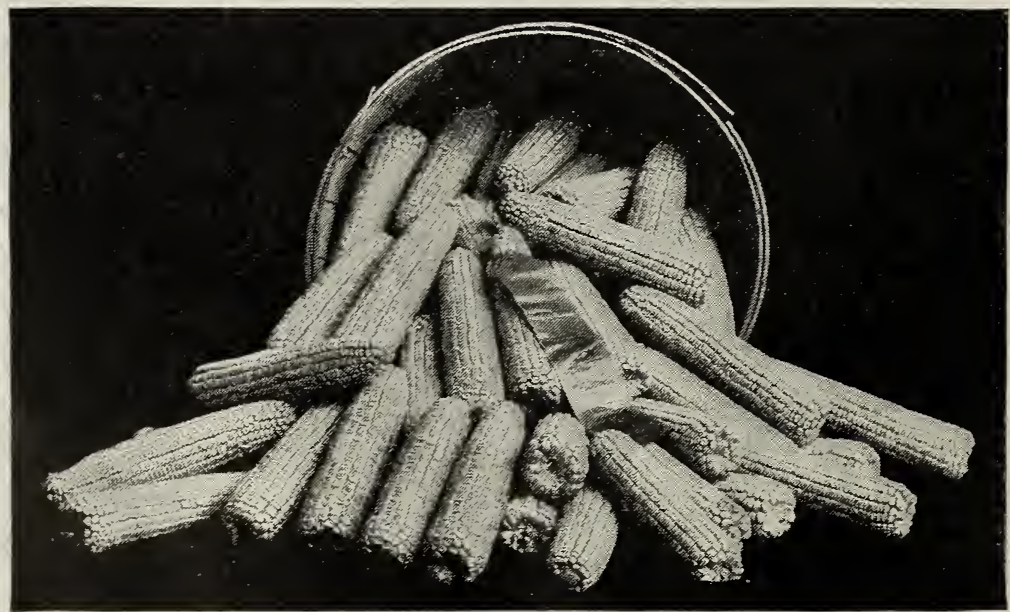

Another Picture of Spangler Silver King Corn. 


\section{WESTERN GROWN AND FODDER CORN.}

The corn offered on this page is all Nebraska grown except the Red Cob Ensilage, which is Missouri grown. That means of course that it will all be later in maturing than Wisconsin corn. It is all good seed corn, however, is well graded and shows high germination tests. We like to see Wisconsin farmers and other Northern farmers order Wisconsin grown corn for their general planting as we know it will ordinarily give the best satisfaction. For silage and for fodder of course the Nebraska corn will do very well, however, and the price will have its attraction. With a favorable season most of it will be all right for ear corn, too.

\section{WHITE CAP}

YELLOW DENT.

This has been a popular variety for years. Kernels are yellow or nearly so except on the outer ends, where they are white. Medium early. Grows quite a large ear, 9 inches or more. Excellent for a silo corn.

Prices: 1/2 pk., 70c; pk., \$1.15; bu., $\$ 3.50 ; 21 / 2$ bus. at $\$ 3.40 ; 10$ bus. at $\$ 3.25$.

\section{GIANT RED \\ COB ENSILAGE.}

\section{A very large pure white corn with} red cob. It grows the largest, doubtless, of any variety of corn and is the favorite for planting in the north for a large growth of green fodder. Does not ordinarily develop ears. Our stock is Missouri grown.

Prices: $1 / 2$ pk., $50 \mathrm{c}$; pk., $85 \mathrm{c}$; bu. $\$ 2.50 ; 21 / 2$ bus. at $\$ 2.40 ; 10$ at $\$ 2.25$.
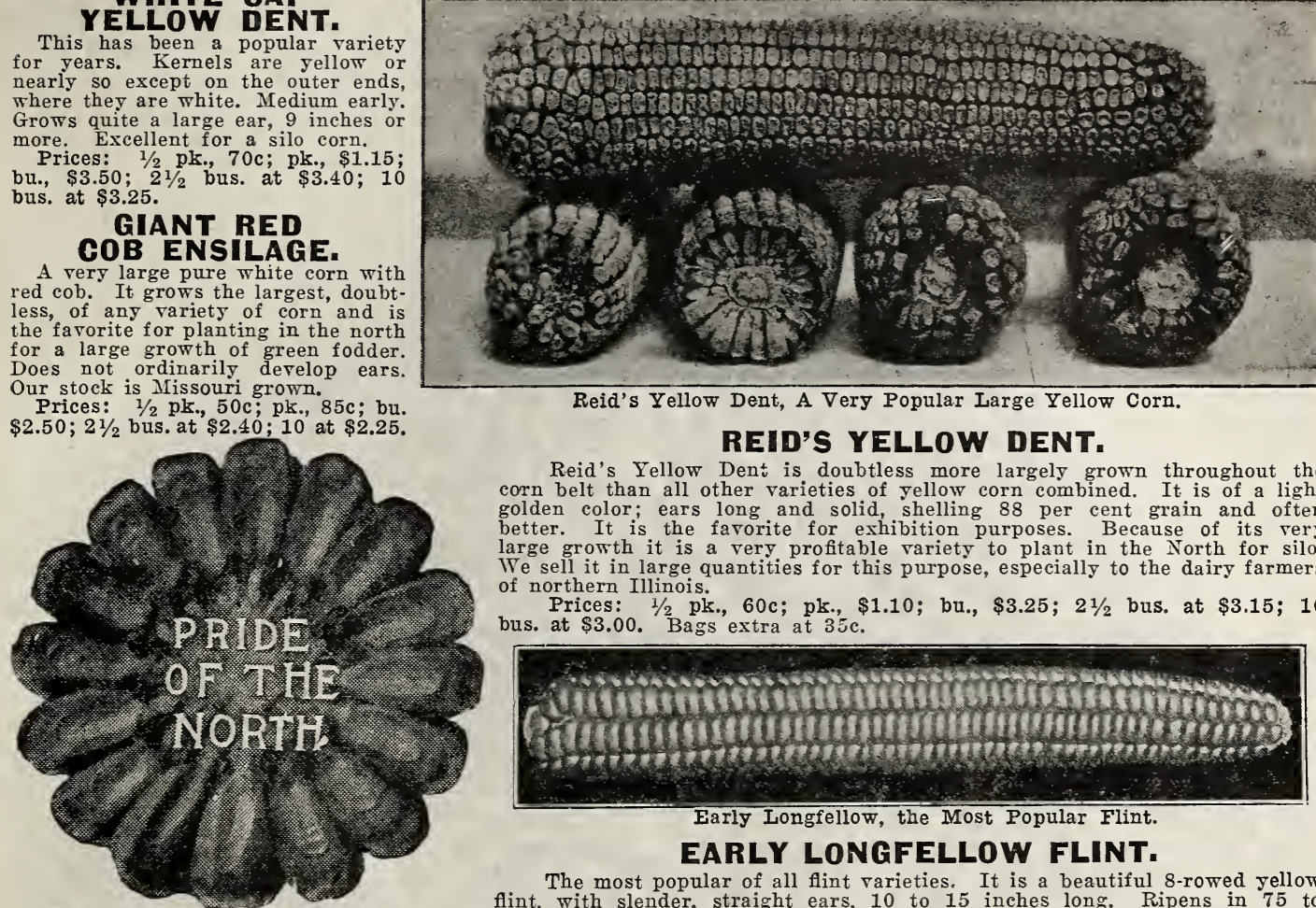

Reid's Yellow Dent, A Very Popular Large Yellow Corn.

\section{REID'S YELLOW DENT.}

Reid's Yellow Dent is doubtless more largely grown throughout the corn belt than all other varieties of yellow corn combined. It is of a light golden color; ears long and solid, shelling 88 per cent grain and often better. It is the favorite for exhibition purposes. Because of its very large growth it is a very profitable variety to plant in the North for silo. We sell it in large quantities for this purpose, especially to the dairy farmers of northern Illinois.

Prices: $1 / 2$ pk., 60c; pk., $\$ 1.10 ;$ bu., $\$ 3.25 ; 21 / 2$ bus. at $\$ 3.15 ; 10$ bus. at $\$ 3.00$. Bags extra at $35 \mathrm{c}$.

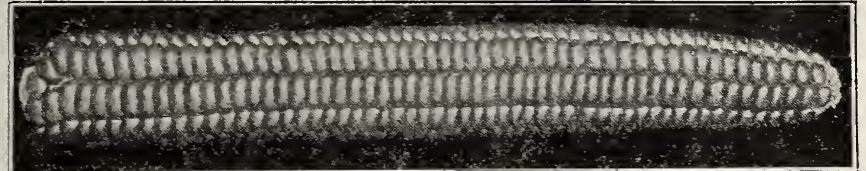

Early Longfellow, the Most Popular Flint.

PRIDE OF THE NORTH.

The old, well-known standard early Yellow Dent. Ears not large but kernels very deep with very small cob. Probably no other variety furnishes as large a percentage of shelled corn.

Prices: 1/2 pk., 70c; pk., \$1.15; bu., $\$ 3.50 ; 21 / 2$ bus. at $\$ 3.40 ; 10$ at $\$ 3.25$.

\section{EVERGREEN SWEET} FODDER CORN.

A fodder grade of Stowell's Sweet Corn. All right for field planting. Prices: $1 / 2$ pk., $85 \mathrm{c}$; pk., $\$ 1.50 ;$ bu. ( 45 lbs.). $\$ 4.50 ; 21 / 2$ bus. at $\$ 4.40 ; 10$ bus. at $\$ 4.25$.

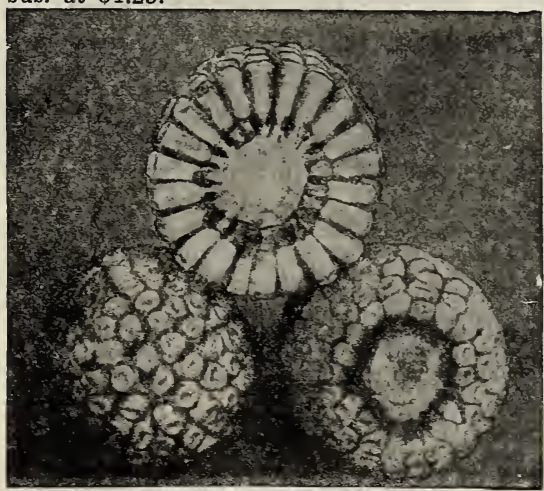

Improved Leaming.

\section{EARLY LONGFELLOW FLINT.}

The most popular of all flint varieties. It is a beautiful 8-rowed yellow flint, with slender, straight ears, 10 to 15 inches long. Ripens in 75 to 85 days.

Prices: $1 / 2$ pk., 75c; pk., $\$ 1.30 ;$ bu., $\$ 4.00 ; 2 \frac{1}{2}$ bus. at $\$ 3.90 ; 10$ bus. at $\$ 3.75$.

\section{SANFORD'S WHITE FLINT.}

A heary rielding, 8-rowed flint with large ears. The ears are 12 to 15 inches long with large, broad kernels of a flinty white color A little larger and a little later than Longfellow. Stalks are tall and leafy with usually 2 or 3 ears each.

Prices: $1 / 2$ pk., $75 \mathrm{c}$; pk., $\$ 1.30 ;$ bu., $\$ 4.00 ; 21 / 2$ bus. at $\$ 3.90 ; 10$ bus. at $\$ 3.75$.

\section{GENESEE VALLEY FLINT.}

A heary yielding flint, a little larger and a very little later than Longfellow, with a larger and a broader kernel. Reddish yellow instead of pure yellow. A very vigorous grower.

Prices: 1/2 pk., 75c; pk., $\$ 1.30 ;$ bu., $\$ 4.00 ; 21 / 2$ bus. at $\$ 3.90$; 10 bus. at $\$ 3.75$.

\section{COMPTON'S EARLY YELLOW FLINT.}

An extra early variety with large ears, averaging 10 inches in length, usually 12-rowed. Small, rich golden-yellow kernels.

Prices: $1 / 2$ pk., 75c; pk., $\$ 1.30 ;$ bu., $\$ 4.00 ; 21 / 2$ bus. at $\$ 3.90$; 10 bus. at $\$ 3.75$.

\section{IMPROVED LEAMING.}

The Leaming is the oldest distinct variety of corn, having been originated in 1826. It is a standard yellow corn, well adapted to northern and central Illinois and the most of Iowa and similar latitudes. In fact, it is grown with success in southern Wisconsin and is in great demand in the North as a silage corn. Largely planted by dairy farmers. Prices: $1 / 2$ pk., $60 \mathrm{c}$; pk., $\$ 1.10 ;$ bu., $\$ 3.25 ; 2 \frac{1}{2}$ bus. at $\$ 3.15$ 10 bus. at $\$ 3.00$.

Any variety of corn on our list-By mail: Ib., 35c; 3 lbs., 90c. By freight: Lb., 30c; 3 lbs., 75c. Samples showing tests free. Half bushels at bushel rates. Bushel sacks extra at $10 \mathrm{c}$ for quantities over one peck; grain bags holding $21 / 2$ bushels, $35 \mathrm{c}$ each.

Prices of corn are subject to change after February 1st. We recommend early orders as the supply of good seed corn is limited. 


\section{OLDS' SEED OATS}

Seed Oats are a specialty with us. Our oats are grown on contract. by careful farmers near Madison. We fur. nish the stock seed, watching and inspecting the crops as they grow. The growers are obliged to treat the seed for smut. The crops are finally delivered at our warehouse, where we thoroughly clean and grade the grain with our up-to.date cleaning machinery. Our oats this year are unusually fine, we think the heaviest and brightest we have ever had.

WISCONSIN PEDIGREE VARIETIES. We are practically confining ourselves now to the Pedigree varieties of oats developed at the Wisconsin Experiment Station. These are the best strains of oats we know anything about.

REGISTERED STOCK. Registered stock as defined by the Wisconsin Experiment Association is stock that was grown from either elite or registered seed, that has been both field inspected and bin inspected by an official inspector, has been found free from noxious weeds and also free from other varieties and other grains, has been well cleaned and graded and shows a final purity test of not less than 99.8 per cent. By elite seed is meant seed that was grown on the Station farm here at Madison and this is all hand rogued.

CERTIFIED STOCK. Certified stock calls for the same inspections as registered stock, with the same rigid cleaning and with freedom from noxious weeds, but the purity test may be as low as 99.5 per cent. One-half per cent mixture of other varieties is allowed or one-tenth per cent of other grains. As a matter of fact all our Certified Stock is from fields entered originally for Registered Stock which in the final test fell just under the required 99.8 per cent.

STANDARD STOCK. Our standard stocks are pure and bright, nearly equal in appearance to the other stocks and just as carefully cleaned but usually from crops that were not field inspected.

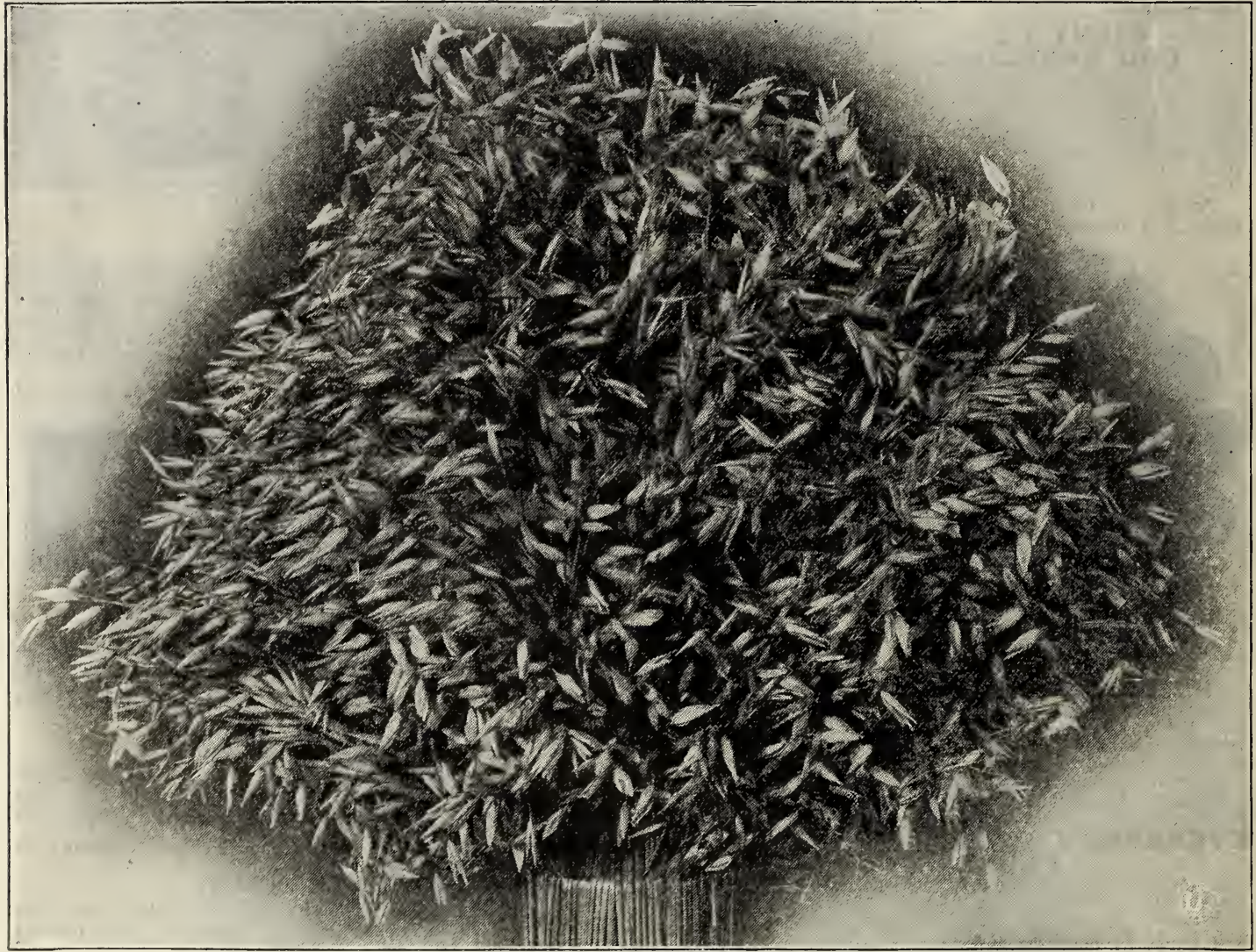

Prize Sheaf of Wisconsin Pedigree No. 7 at one of the Grain Shows of the Wisconsin Experiment Association.

\section{STATE'S PRIDE (WISCONSIN PEDIGREE NO. 7)}

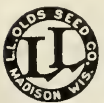

Most Popular Farly Oat and Best Yielder of all Oats at Wisconsin Fxperiment Station Farm Over a Period of 8 years. State's Pride is a new pedigreed variety of oats originated at the Wisconsin Experiment Station. We were the first to offer it, cataloging it for the first time ten years ago. It has come to be a leader with us and continues to grow in popularity each year.

History. State's Pride is a pure line selection from the Kherson variety. The original stock was obtained from the Nebraska Experiment Station and they secured their stock from the Kherson district in Russia, where the climate is dry and early and hardy varieties of oats are grown.

Description. State's Pride is a small yellow oat, bright and shing, with a very thin hull. In fact it is about all meat, very heavy and a great oat for feeding. It is very early. Indeed the earliest of all $\nabla a r i e t i e s$, some 25 or 30, grown at the Wisconsin Station. This is of great importance as it escapes the rust so apt to hit oats just before harvest. Owing to its earliness it is one of the best for a nurse crop for clover and alfalfa.

It has a short stiff straw and has stood up the best of all oats at the Wisconsin Station Farm.

Another thing about this oat is its hardiness. Prof. Ieith says it is the hardiest of anything, resists heat and withstands unfarorable conditions. It is fully recommended for rich soils where ordinary oats will not do well at all. 1n yield per acre at the Wisconsin Experiment Station, State's Pride stood first of all varieties in 1914, 1915, 1927 and the average for 8 years was 9 bush
PRICES OF STATE'S PRIDE FOR 1928.

Registered Stock-By mail: Lb., 25c. By freight: Lb., 20c; 1/2 pk., 25c; pk., 40c; bu., \$1.30. (Bushel sacks extra at $10 \mathrm{c}$.) $21 / 2$ bus. at $\$ 1.25 ; 10$ bus. at $\$ 1.20 ; 25$ bus. or over at $\$ 1.15$. (21/2 bushel sacks extra at $15 c$.)

Certifled Stock: Bu., $\$ 1.20 ; 21 / 2$ bus. at $\$ 1.15 ; 10$ bus. at $\$ 1.10 ; 25$ bus. at $\$ 1.05$.

Standard Stock: Bu., $\$ 1.10 ; 21 \%$ bus, at $\$ 1.05 ; 10$ bus at $\$ 1.00 \% 25$ bus at 950

(See what we say about "Certified Stock" and "Registered Stock" at the top of this page. All orders for less than one bushel will be filled from Registered stock.) -14- 


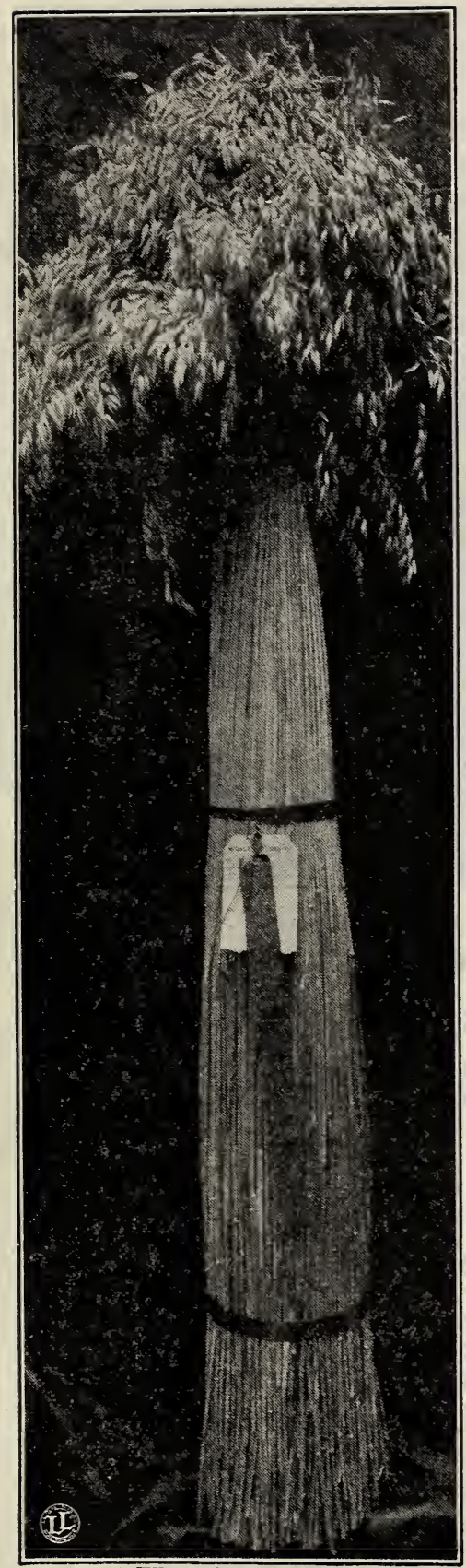

Sheaf of White Cross Oats. First Prize

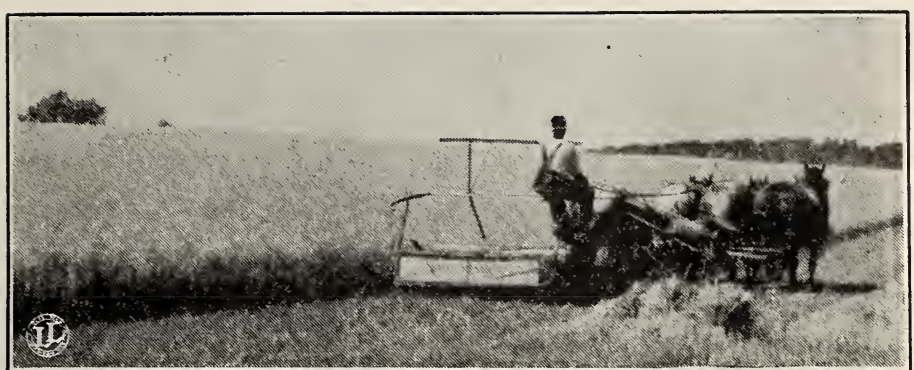

Field of White Cross on the University Farm (Courtesy Wis. Coll. of Agri.).

\section{WHITE CROSS (Wis. Pedigree No. 19)}

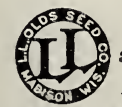

\section{"Finest Appearing Early Oat." Prof. B. D. Leith.}

This is the newest of the Pedigree varieties of oats developed at the Wisconsin Experiment Station and in many respects the best. The small size of the grain and the yellow color were objeceatures in the State's Pride. In the White Cross the at but still maintaining the earliness and high yield. The result of this effort has beeen wonderfully satisfactory.

History: White Cross is a pure line selection from a cross made at the Wisconsin Station in 1911 between Big Four and Sixty Day. A very careful selection was made for several vears until finally this beautiful white extra early and high yielding strain was sent out under the name "White

To sum up these are the outstanding features of White Cross:

First, it is extra early, almost as early as the famous State's Pride.

Second, it is white instead of yellow, with a good sized grain, making

it as Prof. Leith says, "the finest appearing early oat."

Third, it is a heavy yielder, second only to State's Pride at the Wisconsin Experiment Farm and some years outyielding that variety.

Fourth, it grows a taller straw than State's Pride and can always be easily harvested by the binder even on thin poor land.

Fifth, it is the best early oat for light soils, outyielding all other earlies.

This is the fourth year White Cross has appeared in our catalog. It has been gaining in popularity each year. We want to recommend it as a first-class, satisfactory, all-around oat with all the good qualities of our best heavy-yielding main-crop varieties, combined with extreme earliness. PRICES OF WHITE CROSS FOR 1928.

Registered Stock-By mail: Lb., 25c. By freight: Ib., 20c; 1/2 pk., $25 \mathrm{c}$; pk., $40 \mathrm{c}$; bu., $\$ 1.30 ; 2 \frac{1}{2}$ bus. at $\$ 1.25$; 10 bus. at $\$ 1.20 ; 25$ bus. or over at $\$ 1.15$.

Certified Stock: Bu., $\$ 1.20 ; 21 / 2$ bus. at $\$ 1.15 ; 10$ bus. at $\$ 1.10 ; 25$

bus, at $\$ 1.05$

Standard Stock: Bu., $\$ 1.10 ; 21 / 2$ bus. at $\$ 1.05 ; 10$ bus. at $\$ 1.00 ; 25$ bus. at $95 \mathrm{c}$.

(For explanation of different stocks see top of page 14.)

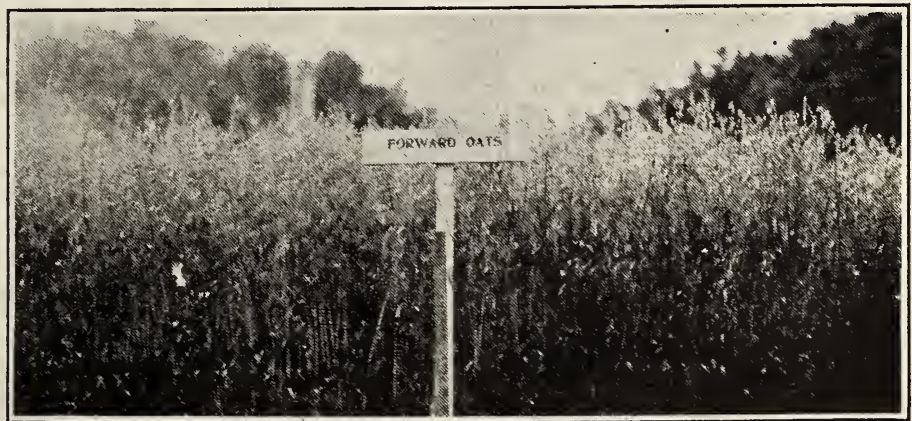

Field of Forward Oats. (Courtesy of Prof. E. J. Delwiche.)

\section{FORWARD (Wis. Pedigree No. 1241)}

\section{Best Oat for Northern Wisconsin.}

Forward is a new pedigreed variety of oats that we offered last vear for the first time. It is a handsome, e, medium early, heavy yielding, plump variety that is giving splendid satisfaction in every way.

History. Forward is a selection from Silver Mine made in 1911, not at the Madison Station but at the Demonstration Station at Superior, being bred further and improved at the Ashland Branch Station. Wisconsin Bulletin 340 describes it as follows:

"It has a white fairly. plump kernel of medium length. The variety stands out conspicuously as the best yielding oats for the northern, or Lake Superior region. It outyielded its nearest competitor by nearly 5 bushels per acre, and Pedigree 5 by 9.6 bushels. Forward is recommended as the best oat for the northern section of the state."

We are glad to have this new oat to offer our customers as an improved strain of Silver Mine. Silver Mine has long been a popular oat with the farmers of the Northwest. Pure white, plump, smooth, heavy, medium early. PRICES OF FORWARD OATS FOR 1928:

Registered Stock-By mail: Ib., 25c. By freight: Ib., 20c; $1 / 2$ pk., 25c; pk., 40c; bu., $\$ 1.30 ; 21 / 2$ bus. at $\$ 1.25 ; 10$ bus. at $\$ 1.20 ; 25$ bus. at $\$ 1.15$.

Standard Stock: Bu., $\$ 1.10 ; 21 / 2$ bus. at $\$ 1.05 ; 10$ bus. at $\$ 1.00 ; 25$ bus. at 95 c. 


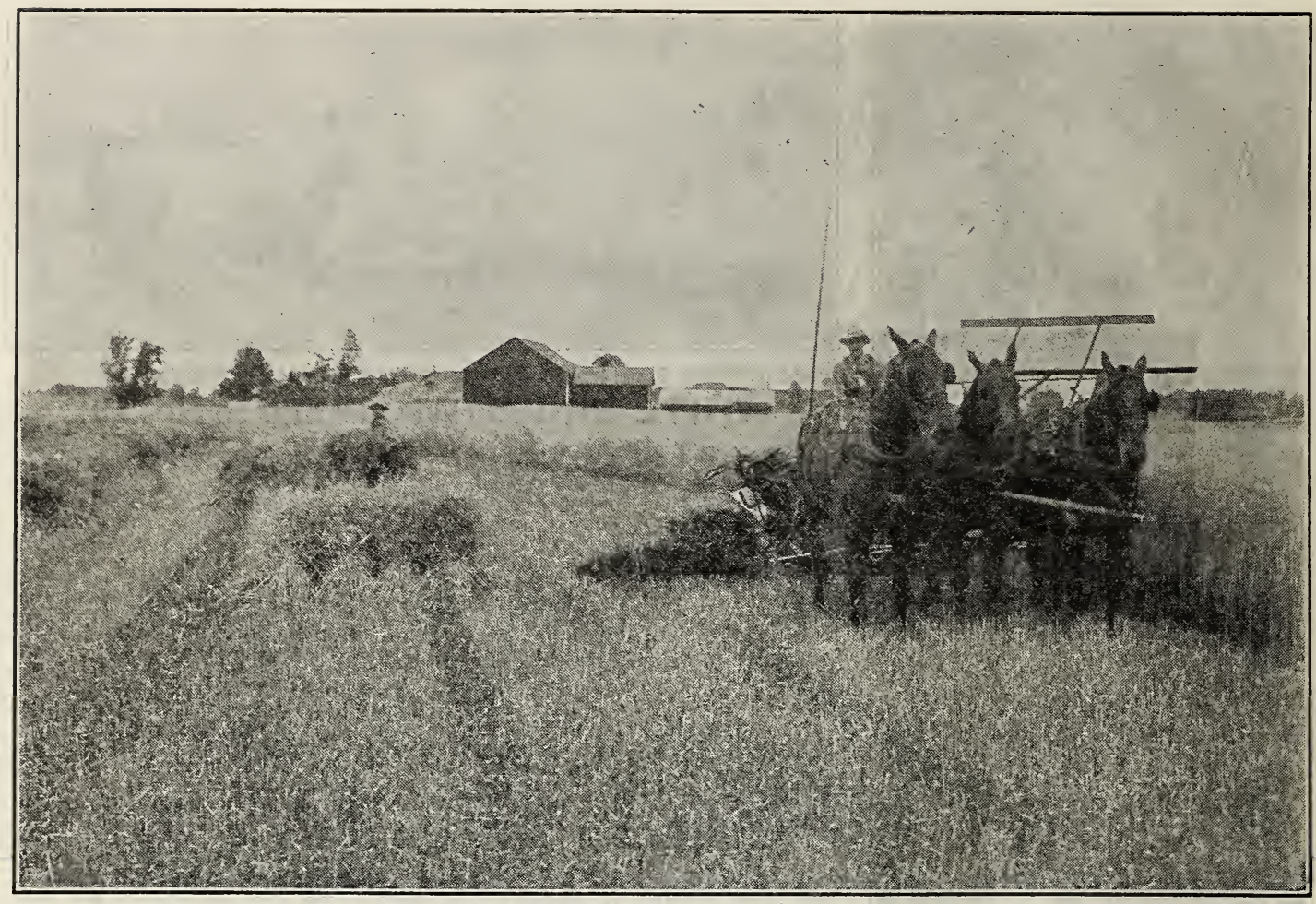

Wisconsin Pedigree No. 1 on Farm of Edward F. Sohn, Manitowoc County.

WISCONSIN PEDIGREE No. 1.

"Most Popular Medium Oat in Wisconsin."

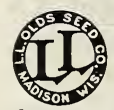
A wonderfully valnahle oat first introduced by us 15 years a Out on the University Farm they called it the "best oat in the world," and Bulletin No. 340, issued in March, 1922, says "The most popular oat in Wisconsin is the Wisconsin Wonder or Pedigree No. 1.'

History. Wisconsin Pedigree No. 1 originated at the Wisconsin Experiment Station in 1901 from a variety called Wisconsin Wonder or Improved Bonanza. About 100 other new varieties of oats were started at the same time. After 14 years of careful breeding work, five pedigree varieties, which went by numbers, were given members of the Wisconsin Ex. Assoc. for trial. Pedigree No. 1 proved the best.

Description. Wisconsin Pedigree No. 1 is a pure white oat, good sized, nice appearing, with rather long kernels. At the Wis. Ex. Station, before State's Pride came along, they made quite a point of the stiffness of the straw. They said: "It's the best oat for medium rich soils thus far bred at the station farm. It will stand up on rich river bottom land and similar locations where Swedish Select usually lodges."

We consider this one of the most valuable oats ever introduced. It is giving satisfaction everywhere. The oats are heavy, good sized, with thin hull, outyield nearly everything, will grow on rich soils and stand up.

PRICES OF WISCONSIN PEDIGREE NO. 1 FOR 1928.

Registered Stock-By mail: Ib. 25c. By freight: Ib. 20c; 1/2 pk., 25c; pk., 40c; bu., $\$ 1.30 ; 21 / 2$ bus. at $\$ 1.25$; 10 bus. at $\$ 1.20 ; 25$ bus. at $\$ 1.15$. Sacks extra.

Certified Stock: Bu., $\$ 1.20 ; 21 / 2$ bus. at $\$ 1.15 ; 10$ bus. at $\$ 1.10 ; 25$ bus. or over at $\$ 1.05$.

Standard Stock: Bu., $\$ 1.10 ; 21 / 2$ bus. at $\$ 1.05 ; 10$ bus. at $\$ 1.00 ; 25$ bus. or over at $95 \mathrm{c}$.

\section{GOLD MINE OATS}

The Oats That Yield Well in An Unfavorable Year.

Gold Mine is not a pedigreed variety but it has been grown so long and has done so well right in this section that we are certainly justified in calling it a Wisconsin variety. It is probably more popular today with the rank and file of Dane County farmers than any other variety.

Gold Mine is a sort of an ironclad. It makes a big strong growth, 4 feet high or more, with splendid, stift straw and large bushy heads. The grain is heavy, plump and of large size. Oats of a shiny golden yellow color.

The color is the only thing objectionable about Gold Mine as of course a white oat sells better in market than a yellow oat. But for feeding it makes no difference. Yellow oats withstand rust better than white oats. Gold Mine seldom rust and they always yield well and they always stand up.

Prices-By mail: Lb., 25c. By freight: Ib., 20c; 1/2 pk., $20 \mathrm{c}$; pk., 35c; bu., $\$ 1.05 ; 21 / 2$ bus. at $\$ 1.00 ; 10$ bus. at $95 \mathrm{c} ; 25$ bus. or over at $90 \mathrm{c}$.

\section{WHITE TARTAR OATS}

\section{Fancy Ohio Grown.}

White Tartar is a plump, pure white variety of oats with kernels a trifle larger than those of Swedish Select, just about as thick and fully as attractive in appearance. The variety is medium in season and grows a straw of medium height. The kernels are free from awns, clean, shiny and bright.

Our stock comes from Ohio and very fine stock it is, as the oats are exceptionally heary, weighing 44 pounds per measured bushel. This is pretty nearly a new variety for us here but it has done remarkably well in Ohio and we are glad indeed to be able to offer it to our customers.

Prices: By mail: Lb., 25c. By freight: Lb., 20c; $1 / 2$ pk., $25 \mathrm{c}$; pk., $40 \mathrm{c}$; bu., $\$ 1.20 ; 21 / 2$ bus. at $\$ 1.15 ; 10$ bus. at $\$ 1.10 ; 25$ bus. or over at $\$ 1.05$.

Remember-Oat prices do not include sacks. Heavy hemmed top jutes, same size and shape as a grain bag and holding $2 \frac{1 / 2}{2}$ to 3 bishels each, are extra at 15 cents each.

Pound and half peck prices, where not given, are the same as for State's Pride. If a large quantity of oats is wanted of any variety write for special prices. 


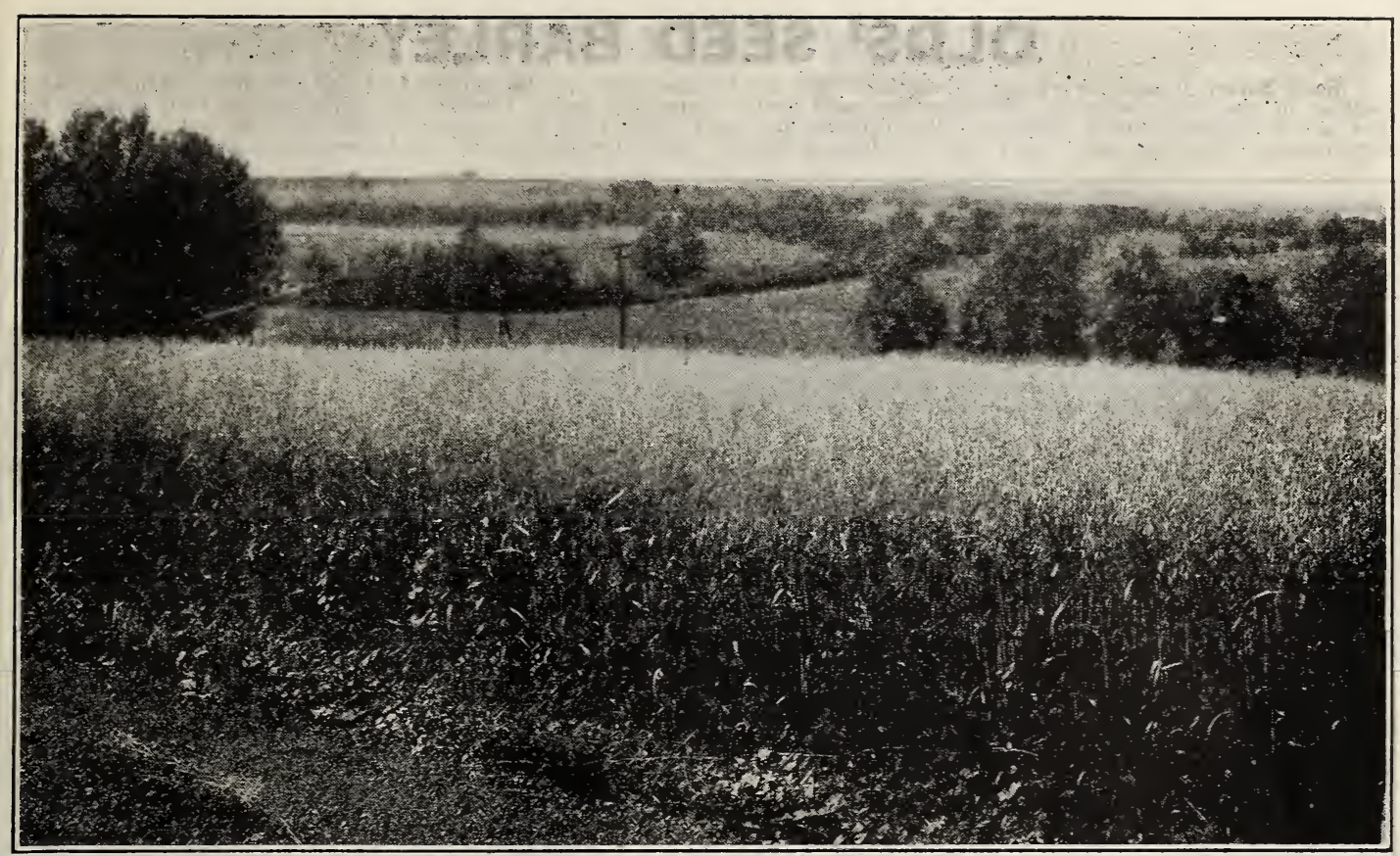

Field of Wisconsin Pedigree No. 5 Oats on the University Hill Farm at Madison.

\section{WISCONSIN PEDIGREE No. 5}

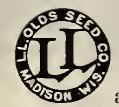

OF ALL the splendid Wisconsin varieties of oats, Wisconsin Pedigree No. 5 is the plumpest and finest appearing. The kernels are large, thick, pure white and most attractive.

History. Wisconsin Pedigree No. 5 is a pure-line selection from the Swedish Select, which was obtained from the U. S. Department of Agriculture in 1898. It was sent out by the WWisconsin Experiment Station about 1913

Description. Wisconsin Pedigree No. 5 grows medium to tall in height with large, thick, spreading heads, very pretty in appearance. The kernels are large, pure white and rery plump so that the threshed oats make a very fine appearance. In fact they are just the type of oats most desired in market and they always bring the highest price. They are emphatically "a show oat." They are heary in weight, running usually from 36 to 42 pounds per measured bushel and they are great yielders, always standing well up toward the top in yield per acre.

Perhaps the only fault they have is that they hare a tendency to lodge on rich soils. They are all right for clay soils and ordinary light soils but we do not recommend them for rich black soils. In season about medium.

Prices, Certified Stock-By mail: Lb., 25c. By freight: Ib., 20c; 1/2 pk., 25c; pk., 40c; bu., $\$ 1.20 ; 21 / 2$ bus. at $\$ 1.15 ; 10$ bus, at $\$ 1.10 ; 25$ bus, at $\$ 1.05$.

Standard Stock: Bu., $\$ 1.10 ; 2 \frac{1}{2}$ bus. at $\$ 1.05 ; 10$ bus. at $\$ 1.00 ; 25$ bus. at 95 c.

\section{EMMER (Speltz).}

Farmers ought to sow more Emmer, which is the proper name of this grain, rather than Speltz. It makes splendid feed and lots of it. Note the following points:

First. It is perfectly hardy and can be grown anywhere.

Second. It yields more per acre than either oats or barley.

Third. It is specially adapted to dry regions. Withstands drouth.

Fourth. It stands up when oats and barley lodge.

Fifth. It makes a well balanced feed for horses, eattle or hogs, as the large hull gires it the lightness of oats, while the double kernel furnishes a rich meal much like ground rye feed.

Sow the same as barley or oats about 100 pounds or $2 \frac{1}{2}$ bushels per acre. It ripens about with oats.

Prices: By mail: Ib., 25c. By freight: Ib, 20c; $1 / 2 \mathrm{pk}_{2} 25 \mathrm{c}$; pk., $40 \mathrm{c}$; bu. (40 lbs.), $\$ 1.20 ; 100$ lbs., $\$ 2.90 ; 500$ lbs. at $\$ 2.85$; 1,000 lbs. at $\$ 2.80$. Sacks extra at $15 \mathrm{c}$.

\section{JAPANESE BUCKWHEAT.}

Succeds well in the extreme north. The grain is very large, of dark brown color. Always higher in market than Silver Hull. Sow buckwheat from June 10 to July 10, one bushel per acre.

Prices: By mail: Lb., 25c. By freight: Lb., 20c; $1 / 2$ pk., $30 \mathrm{c} ;$ pk., 50c; bu. (50 lbs.), $\$ 1.60 ; 2$ bus. at $\$ 1.55 ; 10$ bus. at $\$ 1.50 ; 25$ bus. at $\$ 1.45$. Sacks extra at $15 \mathrm{c}$.

\section{SILVER HULL BUCKWHEAT.}

Silver Hull has a rather small grain, light gray in color, nearly round in shape. Earlier than Japanese according to the Wisconsin College of Agriculture. Very productive and fine for grinding. Prices: $1 / 2$ pk., $30 \mathrm{c} ; \mathrm{pk}$., $50 \mathrm{c}$; bu., $\$ 1.55 ; 2$ bus. at ductive and fine for grinding. Prices: $1 / 2$ pk., $30 \mathrm{c} ;$ pk., $50 \mathrm{c} ;$
$\$ 1.50 ; 10$ bus. at $\$ 1.45 ; 25$ bus. or over at $\$ 1.40$. Sacks extra. 


\section{OLDS’ SEED BARLEY}

Seed Barley is another of our specialties. We are located right in the midst of one of the finest barley growing sections of the whole country. We have our seed barley grown for us on contract the same as our seed oats by the best grain farmers around Madison. We furnish the stock seed, elite or registered, and have the fields entered for registration. The same rules apply for "Registered Stock," and "Certified Stock" as in seed oats. See page 14.

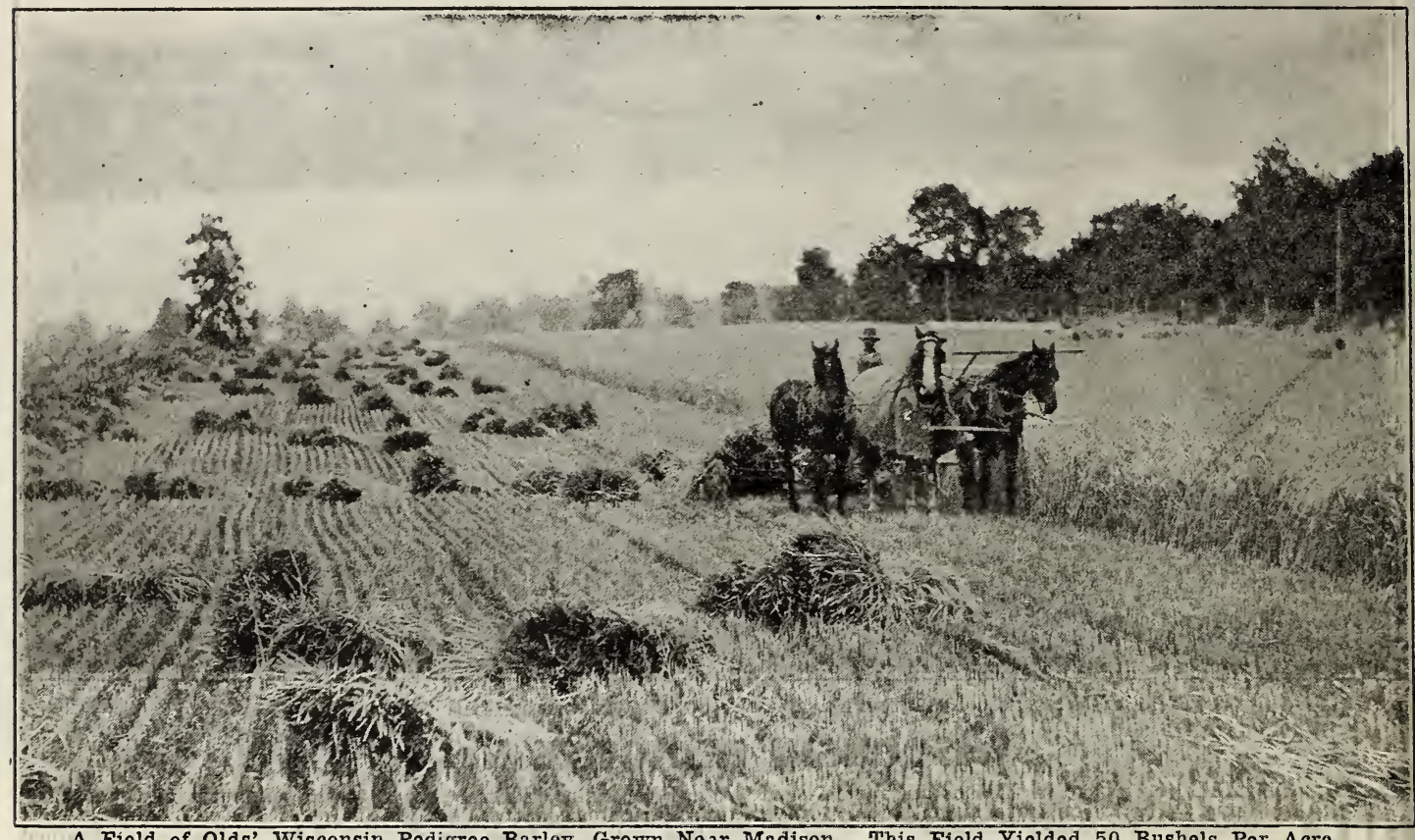

A Field of Olds' Wisconsin Pedigree Barley, Grown Near Madison. This Field Yielded 50 Bushels Per Acre. WISCONSIN PEDIGREE BARLEY.

THE WORLD'S CHAMPION BARLEY.

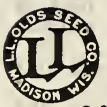

Wisconsin is a great barley state and Wisconsin barley leads the world. Away back in 1895, Manshury barley was first sent out by the Wisconsin Ex. Station. This variety nearly doubled the yield of common barley and was worth millions of dollars to the farmers of Wisconsin alone. Later came Mandschueri, an improved Manshury, and then in 1907, Oderbrucker was first offered and this was ahead of everything else up to that time. Now we have Wisconsin Pedigree, developed from the Oderbrucker and the greatest of all six-rowed barley.

There is really only one variety of six-rowed barley in the world now worth considering-Wisconsin Pedigree. It is by far the best. Forget everything else.

Wisconsin Pedigree Barley is the result of 12 years of painstaking breeding work carried on at the Wisconsin College of Agriculture. Ten varieties of barley were used as the foundation. The number was gradually reduced and finally the pedigreed stock was sent out for trial over the state through the members of the Wisconsin Experiment Association. We first introduced it in 1911 and have catalogued it ever since.

The following are reasons why "Wisconsin Pedigree"' is of such great value:

First:- It outyields all others. The average yield in Wisconsin for 5 years was 22 per cent above the yield of all other barley. Many yields of 50 bushels per acre and over have been reported and some as high as 75 bushels.

Second:- Plumpness of Grain. All notice the unusually plump kernels.

Third:- Stiffness of Straw. Stands up better than any other.

Fourth:- Vigor of growth. Taller than any other barley. We have measured stalks five feet high.

Fifth:-Perfect Development. Heads are more completely filled out than with any other variety.

Sixth:- Large Heads. Many speak of the unusually long, large heads.

Our barley the past season in this section was unusually fine, plumper than last year and brighter. If you want about the finest seed barley you have ever seen, pure, clean, bright and free from oats order our Registered or Certified Stock of Wisconsin Pedigree.

Order early. While we have a large stock we expect an unusual demand for seed and doubt if we will have enough to supply the demand. The farmers of Wisconsin and Illinois are turning more and more from oats to barley as they are finding that barley makes a wonderfully profitable feed crop. It yields ordinarily more pounds per acre than oats if good seed is used.

PRICES OF WISCONSIN PEDIGREE BARIEY FOR 1928.

Registered Stock-By mail: Lb., 25c. By freight: Lb., 20c; 1/2 pk., 30c; pk. $55 \mathrm{c}$; bu., (48 lbs.) $\$ 1.70 ; 2$ bus. at $\$ 1.65 ; 10$ bus. at $\$ 1.60 ; 25$ bus. or over at $\$ 1.55$. Heavy jute sacks, holding two bushels each extra at $15 \mathrm{c}$

Certified Stock: Bu., $\$ 1.60 ; 2$ bus. at $\$ 1.55 ; 10$ bus. at $\$ 1.50 ; 25$ bus. or over at $\$ 1.45$.

Standard Stock: Bu., $\$ 1.50 ; 2$ bus. at $\$ 1.45 ; 10$ bus. at $\$ 1.40 ; 25$ bus. at \$1.35. Sacks extra.

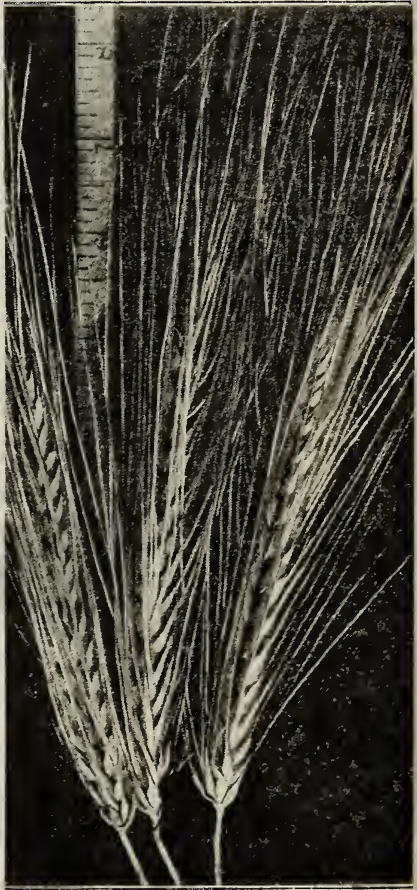

Heads of Pedigree Barley. 


\section{OLDS' SEED WHEAT}

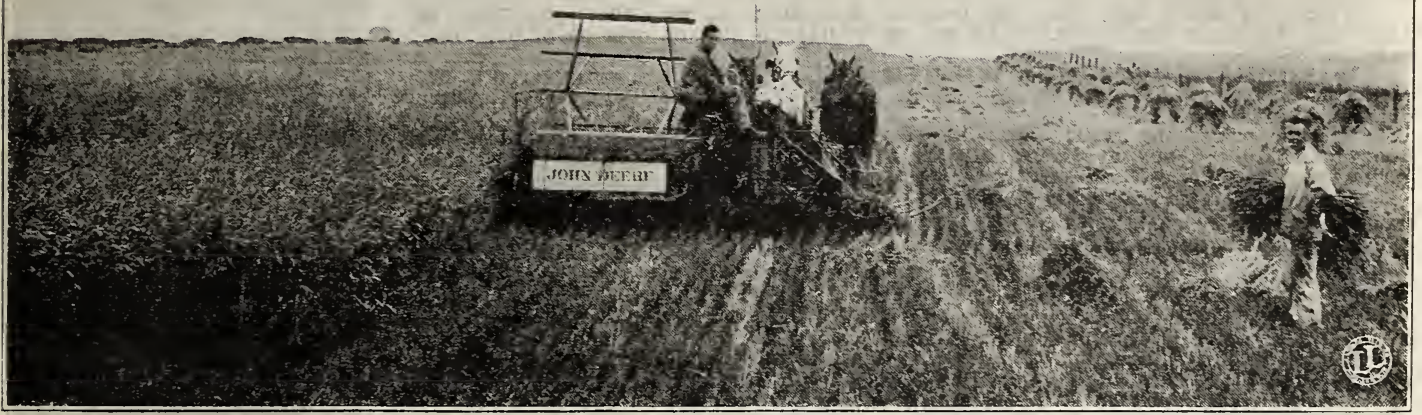

\section{MARQUIS (Best of all Varieties)}

Most Popular Variety of Spring Wheat and Best for Milling.

Marquis Wheat is probably more largely grown throughout the northwest than any other rariety of spring wheat. It seems to do well where spring wheat is not usually grown. In fact it produces great yields of splendid wheat on old farms everywhere, where it was not supposed that wheat would succeed at all.

Description. Marquis is a hard red spring wheat, grading No. 1 Northern, which brings the top price, but is quite different in appearance from Fife and other hard spring varieties. The grains are short and thick and very plump making it rery attractire in appearance. It is a strictly beardless wheat with long heads and it has a very stiff strong straw of good length. It ripens early, a little ahead of other spring varieties.

Our main stock of Marquis this year is fancy Montana grown. It is wonderfully fine wheat-large grain, plump, bright, clean and full of vitality. We have also a. limited stock of Wisconsin grown Marquis, most of it grown from elite seed, but not as plump as the Montana. We offer this at the same price. Mention Wisconsin if preferred.

Prices-By mail: Lb., 25c. By freight: Lb., 20c; 1/2 pk., 45c; pk., 80c; bu., $\$ 2.50 ; 2$ bus. at $\$ 2.45 ; 10$ bus. at $\$ 2.40 ; 25$ bus. 0 or over at $\$ 2.35$. Grain WHEAT (Wisconsin. Pedigree No. 1611)

\section{The Wheat That Does Not Rust.}

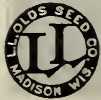

Progress is a new variety of pedigreed sprin wheat that is making a splendid showing for itself wherever it has been tried. The outstanding feature about it is that it does not rust. This is what they say about it at the Wisconsin Experiment Station:

"Progress is a selection from the Early Java variety made at the Marshfield Station in 1915. The specific object in view was to get a wheat that would have a strong resistance to rust, and this strain is out standing in this respect. "It is a bearded, white glumed, hard red spring wheat, and is one of the highest yielder.s." Mr. Edw. F. Sohn of Manitowoc County secured a yield of 45 bushels per acre.

We are glad to be able to offer this new wheat to our customers as a heavy yielding, hard, red, spring wheat that is rust resistant. Most of our stock was grown in Kewaunee County, Northeastern Wisconsin, but we have one lot grown right here near Madison that is "Registered Stock," from University Farm elite seed.

\section{PRICES OF PROGRESS WHEAT}

Registered Stock-By mail: Lb., $30 \mathrm{c}$. By freight: Lb., $25 \mathrm{c}$; $1 / 2$ pk., $50 \mathrm{c}$; pk., $95 \mathrm{c}$; bu., $\$ 2.80 ; 2$ bus. at $\$ 2.75 ; 10$ bus. at $\$ 2.70 ; 25$ bus. at $\$ 2.65$. Bags extra at 35 c

Standard Stock: Pk., 90c; bu., $\$ 2.60 ; 2$ bus. at $\$ 2.55 ; 10$ bus. at $\$ 2.50 ; 25$ bus. or over at $\$ 2.45$.

\section{DURUM WHEAT (Macaroni).}

Durum usually outyields other spring wheat: is very hardy, resisting extremes of weather which no other wheat will endure and is earlier than other wheat. Requires special machinery for grinding. Very desirable for poultry feed.

Prices: Pk., $80 \mathrm{c}$; bu., $\$ 2.50 ; 2$ bus. at $\$ 2.45$; 10 bus. at $\$ 2.40$. Smaller quantities same prices as Marquis.

WISCONSIN PEDIGREE NO. 2 WINTER. Hardiest and best winter wheat for Wisconsin and the Northwest. Developed at the Wisconsin Experiment Station.

Prices: Registered Stock: $1 / 2$ pk., $40 \mathrm{c}$; pk., $75 \mathrm{c}$; bu., $\$ 2.35 ; 2$ bus. at $\$ 2.30 ; 10$ bus. at $\$ 2.25$; 25 bus. or over at $\$ 2.20$. Write for prices next fall when ready to sow.

Standard Stock: Pk., 70c; bu., \$2.15; 10 bus. at $\$ 2.05 ; 25$ bus. at $\$ 2.00$.

GLADDEN WINTER WHEAT, A hard, red, bearded wheat, much like Wisconsin Pedigree in appearance, but with thicker, plumper kernels.

Prices: Same as for Standard Wisconsin Pedigree.

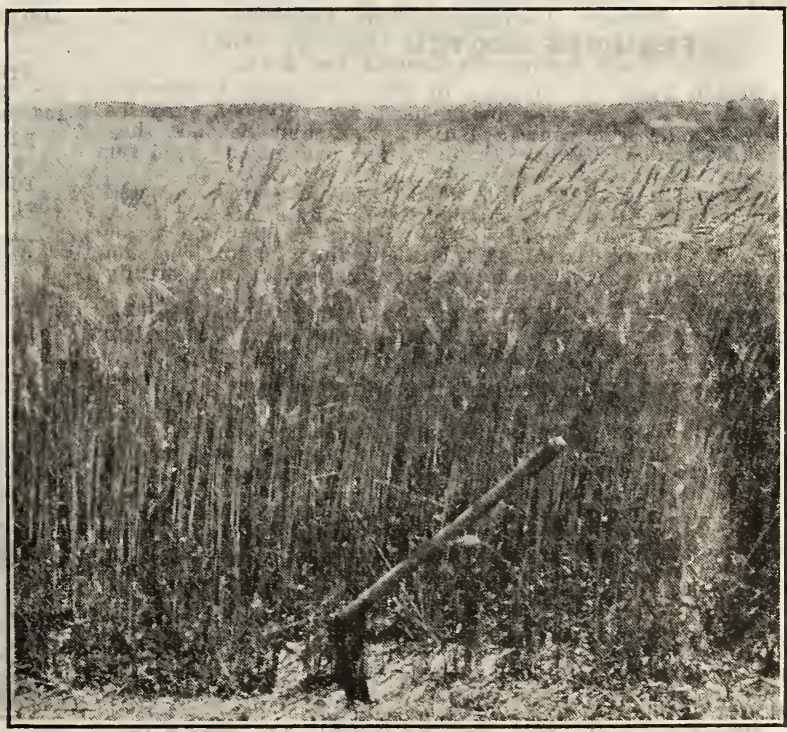

One Corner of a Field of Progress. (Courtesy of Prof. Delwiche.) 


\section{OLDS' SEED RYE}

Wisconsin is a great rye state. We are in position to furnish pure seed of the best varieties at reasonable prices. Write for prices when ready to buy.

\section{SPRING RYE.}

Spring Rye is entirely distinct from Winter Rye. It can be sown in the spring a little later even than most other spring grain and a crop harvested the same season. There is more and more demand for the seed each year as farmers are finding out the value of this crop. Grows a tall strong straw and produces ordinarily 30 to

40 bushels per acre. Lb., 25c. By freight: Lb., 20c; $1 / 2$ pk., 40c; pk., 70c; bu. (56 lbs.), $\$ 2.15 ; 2$ bus. at $\$ 2.10 ; 10$ bus. at $\$ 2.05 ; 25$ bus. or over at $\$ 2.00$. Bags

WISGONSIN PEDIGREE WINTER RYE. Wisconsin's great variety. The result of 12 years' breeding at the Wisconsin Experiment Station. Heavy, plump, uniform kernels.

Present prices, by mail: Lb. 25c. By freight: Lb., 20c; $1 / 2$ pk., $35 \mathrm{c}$; pk., $60 \mathrm{c}$; bu., $\$ 1.90 ; 2$ bus. at $\$ 1.85 ; 10$ bus. at $\$ 1.80 ; 25$ bus. at $\$ 1.75$. Bags extra. Write for "Fall Price List', next September.

ROSEN WINTER RYE. A new variety from Michigan that is now becoming famous everywhere. Greatly out yields ordinary rye. Very attractive in appearance.

Prices, same as for Wisconsin Pedigree Rye.

\section{WILT-RESISTANT FLAX.}

Recently dereloped at the Minnesota Experiment Station. Wilt-resistant and rust-resistant and a better yielder than the ordinary flax.

Prices, by mail: Lb., 30c. By freight: Ib., 25c; $1 / 2$ pk., 60c; pk., \$1.15; bu., (56 lbs.) $\$ 3.50 ; 2$ bus. at $\$ 3.45 ; 10$ bus. at $\$ 3.40$. Bags extra at $35 \mathrm{c}$.

COMMON FLAX.

Prices: Pk., $\$ 1.10$; bu., $\$ 3.25 ; 2$ bus. at $\$ 3.20 ; 10$ bus. at $\$ 3.15$. Bags extra.

\section{OLDS' FIELD PEAS.}

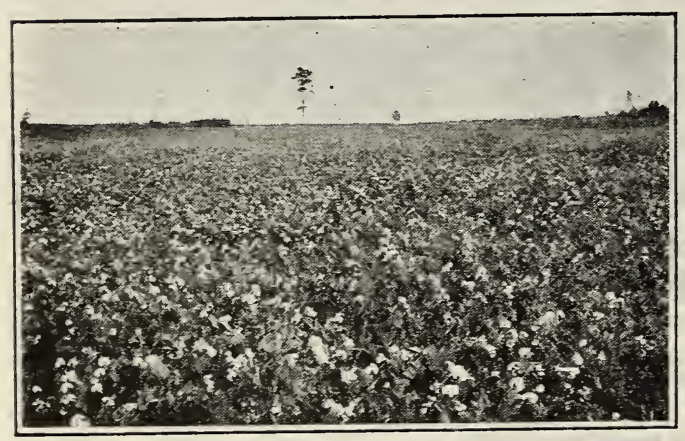

A Field of Pedigree Scotch Peas at the Ashland Branch Station. Courtesy of Prof. Delwiche.

PEDIGREE SCOTGH (Wis. No. 9152)

Yield Record, 50 Bushels Per Acre.

Scotch Peas are superior to White Canadas in two respects. First, because being used for culinary purposes they usually command a better price, and Second, they usually produce better. Further, they are just as good for

hay as the white.
Wisconsin Pedigree No. 9152 is a pure line, selected and developed at the Ashland Station, by Professor E. J, Delwiche. Yield record at the station is 50 bushels per acre as compared with 31.4 bushels the vield of common Scotch. Our stock, grown in Door County, is wonderfully fine pure stock.

Prices, by mail: Lb., 30c. By freight: Lb., 25c; $1 / 2$ lbs. or over at $\$ 5.75$. Bags free.

\section{DWARF ESSEX RAPE.}

Dwarf Essex Rape makes quick pasture and is rery raluable feed. It is ideal for sheep pasture, and is also now largely sown for hogs and cattle. It may be sown in the following ways:

First. In early spring, 5 to 10 pounds per acre.

Second. With spring grain or just as it begins to come up. 2 pounds per acre to provide pasture after harrest. Third. Alone in June or July, on newly plowed land.

Fourth. With corn just before the last cultivation.

Fifth. With rve, in August or September.

A word about the seed. We buy in car lots and han. dle only the best and purest Number One Holland Grown Dwarf Essex; seed that is entirely free from bird rape, mustard and everything of that sort. This is much more desirable than Japanese or German rape.

Prices, by mail: Lb., 30c. By freight: Lb., 25c; 5 lbs. $75 \mathrm{c} ; 10$ lbs., $\$ 1.25$; 25 lbs., $\$ 2.25$; 100 lbs., $\$ 8.00 ; 500$ lbs. at $\$ 7.75$. Bags free.
Prices subject to change after Febru"'W 1st. Ask for after that date.

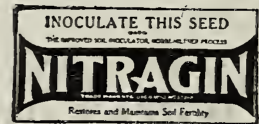

WHITE CANADA. Sometimes called Yellow variety. Should be sown more largely. Makes splendid hay. Sow $11 \%$ bus. per acre broadcast with the same amount

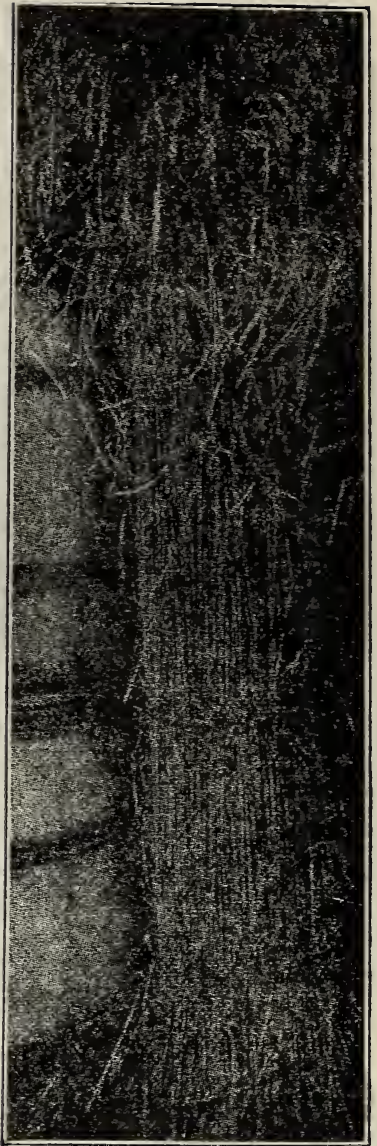

Spring Rye. oats. Our stock is Wisconsin grown and very fine seed.

Prices, by mail: Lb., 30c. By freight: Lb., $25 \mathrm{c} ; 1 / 2 \mathrm{pk}$., $65 \mathrm{c}$; pk., \$1.25; bu. (60 lbs.), \$3.75; 100 lbs., \$6.00; $500 \mathrm{lbs}$. at $\$ 5.75$. Bags free.

\section{WHITE NAVY BEANS.}

Prices, by mail: Lb.. 30c. BY freight: Lb., 25c; $1 /$ pk., $80 \mathrm{c} ;$ pk., $\$ 1.50$; bu., $\$ 4.60 ; 100 \mathrm{lbs}$., $\$ 7.50 ; 500$ bs. at $\$ 7.25$. Bags free.

RED KIDNEY BEANS. Prices by freight: Lb., 35c; $1 / 2$ pk., $\$ 1.00$; pk., $\$ 1.85 ; 60$ lbs., $\$ 5.50 ; 100$ lbs., $\$ 9.00$. BROWN SWEDISH BEANS, Prices, by freight: Lb. $30 \mathrm{c}$; $1 / 2$ pk., $90 \mathrm{c}$; pk., $\$ 1.65$; bu., $\$ 4.90$; $100 \mathrm{lbs}$., $\$ 8.00$.

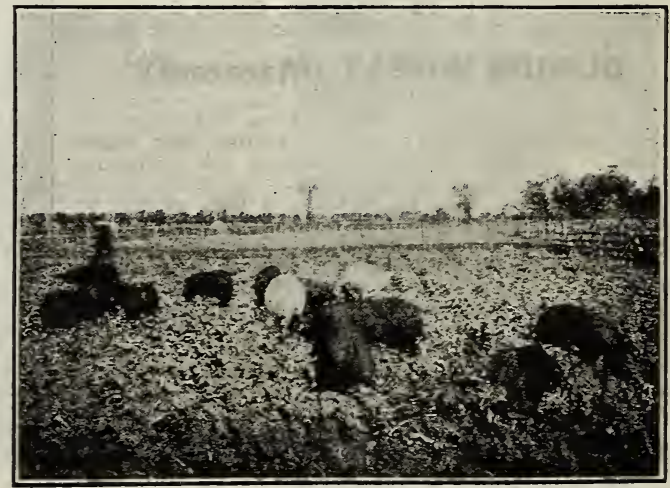

"A Field of Rape is of Inestimable Value in Maturing Profitable Porkers.' 'Breeders' Gazette. 
START WITH SOY BEANS THIS YEAR. This is the year to put in Soy Beans. The seed is wonderfully fineclean, bright, fully matured and high in germination and moreover the price is the lowest in years. The expense of the seed need not leep any farmer from planting Soy Beans this year.

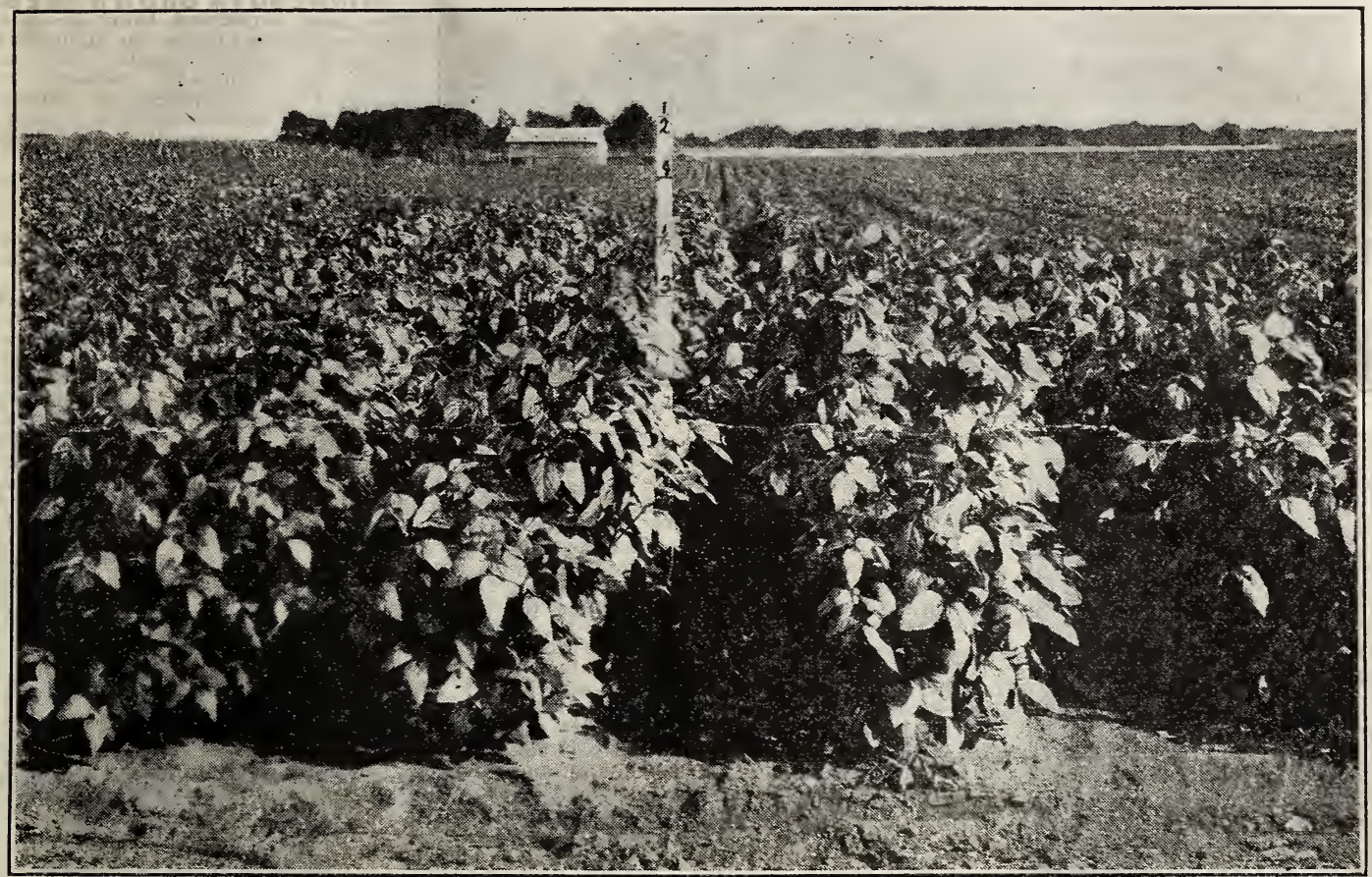

Soy Beans on the Experiment Station Farm, Madison. (Courtesy Wisconsin College of Agriculture.) SOY BEANS

"The Annual Alfalfa." Prof. Geo. M. Briggs, Wisconsin College of Agriculture WHY GROW SOY BEANS?

First. They yield large amounts of high protein forage, rich in feeding value. They not only make splendid hay, but are wonderful for silage, grown with corn.

Second. The mature beans ground into meal make wonderful dairy feed.

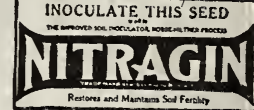

Third. They are very valuable for "'hogging off"' and "sheeping off."

Fourth. They are adapted to nearly all soils and are especially valuable on soils too poor for other legumes.

Fifth. Soy Beans are more resistant to frost than corn and they also stand hot weather.

Sixth. The yield of other crops following Soy Beans is larger due to the fertility left in the soil.

Seventh. They make a wonderful emergency crop when clover fails or when other crops are washed out or fail for any reason, as they can be put in late. No special machinery is required for handling.

CULTURE. If planted with corn 3 beans in each hill of corn is about right and this requires 3 to 5 pounds per acre. If planted alone, for hay or seed, in rows with corn plinter or drill, a half bushel or a bushel of seed per acre may be profitably used, distributing the beans about one inch apart in the row. Rowing and cultivating, however, is not necessary. Thousands of farmers now are planting in solid drill, using a harrow or weeder and caring for large fields at small expense. Do not plant too early. Never before corn planting time. The seed should be inoculated before planting. See pages 4 and 5 . Ask for Wisconsin Bulletin No. 375, 'Soy Beans a Good Legume Crop.'

\section{VARIETIES OF SOY BEANS}

\section{MANCHU}

By far the most popular soy bean in all the states of the middle west and the most valuable. It has jumped into prominence ahead of everything else and is fast displacing other varieties. Early enough to fully mature under ordinary conditions and large enough to be of real value. It is a medium early variety nearly as early as Ito San and quite a little larger. Matures dry beans in about 100 days. Originally from northern Manchuria. Seeds yellow with a peculiar black seed scar. The favorite at the Wisconsin Experiment Station for hay and for silage and also for dry beans and very highly recommended by them. We really do not see why anyone should want any other variety as we consider Manchu the best of all Soy Beans for any purpose. We have very fine seed.

Prices: By mail: Lb., 30c; 3 lbs., 70 c. By freight: Lb., 25c; $1 / 2$ pk., 60c; pk., 90c; bu., \$2.75; 100 lbs., $\$ 4.50 ; 500$ lbs. at $\$ 4.25$.

\section{BLACK EYEBROW}

A trifle earlier perhaps than Manchu and nearly if not quite as valuable. The beans are yellow in color with a peculiar black blotch. Hence the name.

Prices: 1/2 pk., 50c; pk., 90c; bu., \$2.75; $100 \mathrm{lbs}$.,

\section{WISCONSIN BLACK}

A pedigreed strain of Early Black developed at the Wisconsin Experiment Station. Earliest of all. Best variety for Northern Wisconsin. Our stock is Wisconsin grown

Prices: $1 / 2$ pk., $70 \mathrm{c}$; pk., $\$ 1.30$; bu. (60 lbs.) $\$ 4.00$; 100 lbs., $\$ 6.50 ; 500$ lbs. at $\$ 6.25$.

\section{MIDWEST}

The new name given to Medium Yellow, Mongol, Roosevelt and Hollybrook. Requires 120 days to mature.

Prices: $1 / 2$ pk., 50c; pk., 90c; bu., $\$ 2.75$; 100 lbs., $\$ 4.50 ; 500$ lbs. at $\$ 4.25$.

\section{A. $\mathrm{K}$.}

Similar to Midwest but 10 days earlier

Prices: $1 / 2$ pk., 50c; pk., 90c; bu., $\$ 2.75 ; 100$ lbs., $\$ 4.50 ; 500$ lbs. at $\$ 4.25$.

\section{ITO SAN}

Popular early variety. Produces small yellow beans. Prices: $1 / 2$ pk $55 \mathrm{c}$; pk. \$1.00; bu., \$3.10; $100 \mathrm{lbs.}$ $\$ 5.00 ; 500 \mathrm{lbs}$. or over at $\$ 4.75$.

NOTE:--Prices are subject to change after Feb. 1st. Consult "Weekly Price List." All prices include sacks. 2 oz. pkt. any variety soy beans 5c, postpaid. Pound -21 pr 


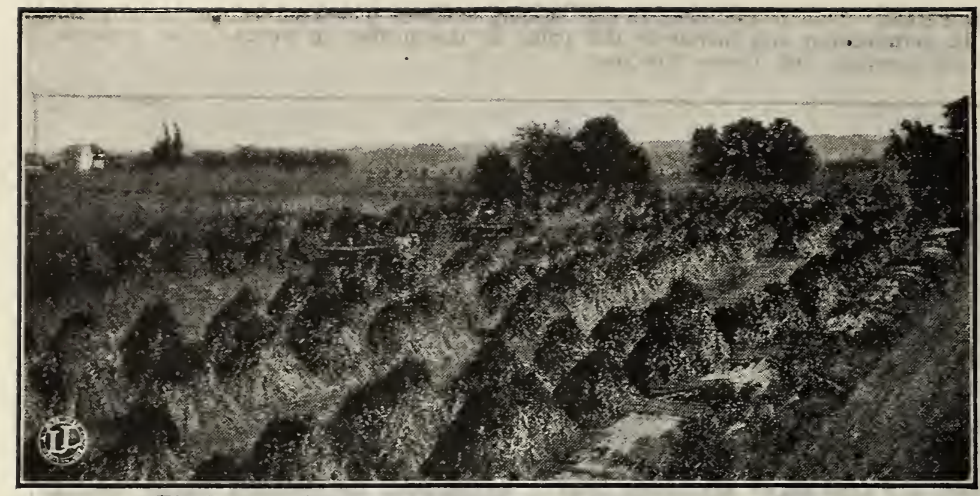

Field of our Improved Early Amber, Grown in Minnesota.

\section{EARLY AMBER CANE}

MINNESOTA GROWN SEED.

The most important thing in rais. ing sorghum is to have the right kind of seed. We are again able to
offer an improred strain of Early Amber, grown in Minnesota. This strain has been developed by selective breeding for hardi. ness and early maturity.

In fact this seed comes from the largest sorghum growers in the United States, where they make a business of scientifically producing cane with the highest possible sugar content.

This strain is absolutely pure Early Amber. There is nothing else in it. And the germination test is high. With this seed it is not necessary to plant as early and the most.of the work, so far as handling weeds is concerned, can be done be-

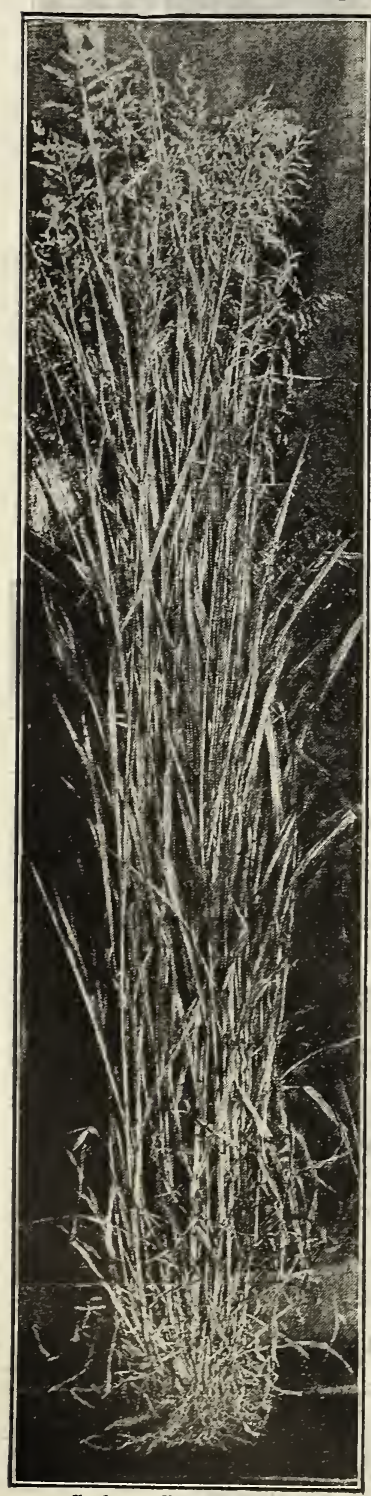

Sudan Grass. fore planting time by thorough discing and harrowing. Culture. Plant about the middle or last of May, after the ground becomes warm, preferably on fall plowed land, in rows 3 to 4 feet wide, hills 2 to 3 feet apart, putting 10 to 15 seeds in a hill and later thinning to 6 or 8 stalks. This is for syrup making purposes and requires about 4 to 6 pounds of seed per acre. For fodder purposes drill thicker in the row, 15 to 18 pounds per acre. An ordinary corn planter will handle the seed in either case but do not plant more than an inch in depth. Some farmers of late years are planting corn and cane together for silage. The cane makes sweeter and finer quality feed than the corn. We recommend the Minnesota seed for fodder as well as sorghum as it will yield more tonnage per acre than the Southern seed.

Prices, by mail: Lb., $30 \mathrm{c} ; 3$ lbs., 65c. By freight: Lb., 25c; 5 lbs., 75c; 10 lbs., \$1.25; 100 lbs., $\$ 7.00 ; 500$ lbs., at $\$ 6.75$.

SOUTHERN EARLY AMBER CANE.

Use this seed for fodder only. Not equal to our Minnesota grown seed but good stuff and cheaper.

Prices, by freight: 5 lbs., $40 \mathrm{c} ; 10 \mathrm{lbs}$., $70 \mathrm{c}$; 100 lbs., $\$ 4.50 ; 500$ lbs., at $\$ 4.25$. Sacks free.

\section{WHITE KAF FIR CORN.}

Makes the best kind of fodder for cattle or horses. Easily grown. The seed is splendid for poultry.

Sow in rows $2 \frac{1}{2}$ to $3 \frac{1}{2}$ feet apart and cultivate the same as corn. Five to ten lbs. will seed an acre in rows, or one-half bushel broadcast. freight: Lb., 20c; 5 lbs., $40 \mathrm{c} ; 10 \mathrm{lbs}$;, 60c; 100 lbs., $\$ 4.00 ; 500$ lbs., at $\$ 3.75$. Sacks free.

\section{FETERITA.}

The Great Drought Resister.

Feterita is rather a recent introduction but it has already made a great name for itself. It is earlier than Kaffir Corn, outyields it and is little affected by drought. Culture same as for Kaffir Corn.

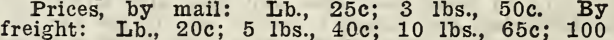
Ibs., $\$ 4.25 ; 500 \mathrm{lbs}$., at $\$ 4.00$ Sacks free.

\section{MILO MAIZE}

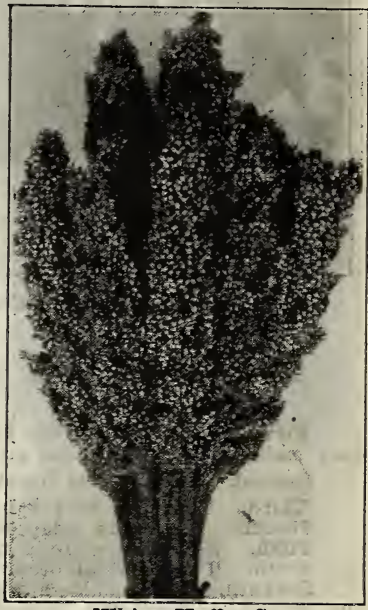

A variety of sorghum, fine for dry weather. Grows very large, 8 to 10 feet high, with seed heads of great size, often weighing $3 / 4$ of a pound each. Plant same as Kaffir. Prices, by mail: Lb., 25c; 3 lbs., 50c. By freight: Lb., 20c; 5 lbs., 40c; 10 lbs., 60c; 100 lbs., $\$ 4.00 ; 500 \mathrm{lbs}$. at $\$ 3.75$. Sacks free.

\section{SUDAN GRASS.}

Great for both Hay and Pasture.

Prof. Mortimer, of the Wisconsin College of Agriculture, places Sudan Grass second in value on the rist of "Emergency Hay Crops," next to soy beans and better than millet or field peas. The following are some of the reasons why it is valuable:

First. It makes a heavy yield of hay, outranking all the millets in yield per acre. Yields of 2 to 4 tons of cured hay per acre from one cutting, are common in Wis. consin. Two cuttings a season can often be made.

Second. It can be pastured. After the hay crop is taken off it makes a fine late pasture as it grows up again quickly. Or, it can be pastured all the season instead of being cut for hay.

Third. It makes a better quality hay than millet and is easily cured, making a bright, leafy, palatable hay. Is relished by both horses and cattle.

Fourth. It can be sown late, after you are through with your corn, or when corn fails. Sow any time from Miay 15 th to July 1 st, 20 to 25 pounds per acre. Do not sow too early. It is strictly a warm weather crop and if put in too early the seed will rot. Fifth. It is very valuable as a smother crop, especially for quack grass.

We recommend Sudan Grass very highly. It grows quickly, produces enormously and is an easy crop to handle. It is strictly an annual and dies down at the end of

the season. The seed is very low in price this year. Sow it liberally
Prices, by-mail: Pkt., 5c; 1b., 30c; 3 lbs., 60c. By freight: Ib., 25c; 5 lbs., $50 \mathrm{c}$; $10 \mathrm{lbs}$., $75 \mathrm{c}$; $100 \mathrm{lbs}$., $\$ 5.00 ; 500$; $1 \mathrm{bs}$. at $\$ 4.75$. Sacks included.

Ask us for Wisconsin Bulletin No. 359, "Emergency Hays and Pastures," mailed free

Note-Bags free for everything on this page. Write for special prices in largo quantities and for new price list after February 1st. Samples showing tests free. 


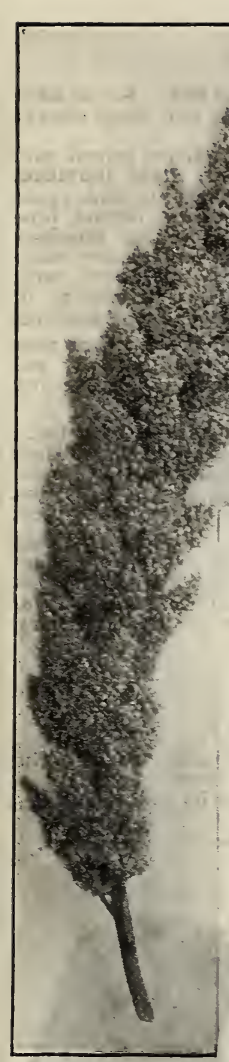

WHITE
WONDER

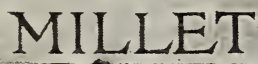

THE BEST MILLET.

We unhesitatingly pronounce White Wonder the best of all the millets.

First. It produces more tons of hay

per acre than any other millet.

Second. In spite of the very large growth the foliage is thick, with numerous broad leaves so that it furishes a high grade of millet har.

Third, Earliness. Thite Wonder is earlier than either German or Common Millet and is well adapted to sowing in the north.

Fourth. It outyields an other mil. let as a seed crop. C. L. Newhouse of Rock County, Wisconsin, secured an average yield of between 50 and 60 bushels of seed per acre.

Fifth. It has much longer and larg. er heads than any other millet. That is the reason for the big yield. George C. Snyder of Richland County, Wis consin, sent us a dozen heads, the shortest one $81 / 2$ inches long, the long est 11 inches, one head measuring $4 \frac{1 / 4}{4}$ inches in circumference.

We recommend White Wonder most highly. Prices are low this year and our seed is very fine. Sow liberally.

PRICES OF WHITE WONDER FOR 1928:

By freight: Lb., 20c; 5 lbs., $40 \mathrm{c} ; 10$ lbs., $70 \mathrm{c} ; 100$ lbs., $\$ 4.25 ; 500$ lbs. at $\$ 4.00$. Bags extra at $35 \mathrm{c}$

JAPANESE MILLET. (Billion Dollar Grass.) Crop failure. Prices so high we are not handling.

A great food for poultry and hogs. Also grown quite largely now for silage. Also for sheep pasture. It makes a larger amount of feed than ensilage corn and is superior in feeding value to corn. Our stock is American grown. lbs., 90c; 10 lbs., $\$ 1.50 ; 100$ lbs., $\$ 10.00 ; 500$ lbs. at $\$ 9.50$. Bags free.

\section{SAND VETCH OR WINTER VETCH. \\ (VICIA VIILOSA)}

A very valuable leguminous plant, especially for lighter soils. Can be sown in either spring or fall. Sow 15 to 20 pounds of retch and $1 / 2$ bushel grain per acre, oats or barley in the spring, rye in the fall. Makes very fine fall and winter pasture and it can also be pastured in early spring. It not only makes the finest kind of feed, but it brings fertility to the soil.

Prices, by mail: Lb., 35c; 3 lbs., 90c. By freight: Lb., 30c; 5 lbs., \$1.25; 10 lbs., \$2.25; 100 lbs., $\$ 16.00 ; 500$ lbs. at $\$ 15.75$. Bags free.

\section{STOCK VEGETABLES.}

As we specialize in farm seeds and so do a large business direct with the farmers we receive many large orders for Stock Vegetable Seed. We are able to make the following low prices on these items in quantity:

MANGELS and SUGAR BEETS. See page 33.

Mammoth Long Red, Giant Eckendorf, and Golden Tankard: Ib., 55c; 5 lbs. at $50 \mathrm{c} ; 10 \mathrm{lbs}$. or over at $45 \mathrm{c}$.

Giant Half Sugar: Lb., 60c; 5 lbs. at 55c; $10 \mathrm{lbs}$. or over at $50 \mathrm{c}$.

Klein Wanzleben: Lb., $55 \mathrm{c} ; 5$ lbs. at $45 \mathrm{c} ; 10$ lbs. or over at $40 \mathrm{c}$.

Danish Sludstrup: Ib., 70c; $5 \mathrm{lbs}$. at $60 \mathrm{c} ; 10 \mathrm{lbs}$. or over at $50 \mathrm{c}$.

CARROTS. See page 36.

Mastodon and Long Orange Belgian: Ib., 80c; 5 lbs. at $60 \mathrm{c} ; 10 \mathrm{lbs}$. at $50 \mathrm{c}$. Oxheart and Improved Long Orange: Ib., 90c; 5 Ibs. at $75 \mathrm{c} ; 10$ Ibs. at $65 \mathrm{c}$. Danvers Half Long: Lb., $\$ 1.20 ; 5 \mathrm{lbs}$. at $\$ 1.00 ; 10 \mathrm{lbs}$. or over at $85 \mathrm{c}$. PUMPKIN. See page 53.

Large Conn. Yellow Field: Lb., 60c; 5 lbs. at 45c; 10 lbs. or over at 35c. King of Mammoths: Lb., $\$ 1.45 ; 5$ lbs. at $\$ 1.15 ; 10$ lbs. or over at $\$ 1.00$. TURNIPS AND RUTABAGAS. See page 60

Purple Top Strap Leaf and Purple Top White Globe Turnip: Ib., 70c; 5 lbs. at $55 \mathrm{c} ; 10 \mathrm{lbs}$. at $35 \mathrm{c} ; 100 \mathrm{lbs}$. or over at $25 \mathrm{c}$

Cow Horn: Lb., 65c; 5 lbs. at 50c; 10 lbs. at $35 \mathrm{c} ; 100 \mathrm{lbs}$. or over at $25 \mathrm{c}$. Improved Purple Top and Golden Heart Rutabagas: Lb., 70c; 10 lbs. at $35 \mathrm{c}$. (Note:-The above prices are for shipment by freight or express.)

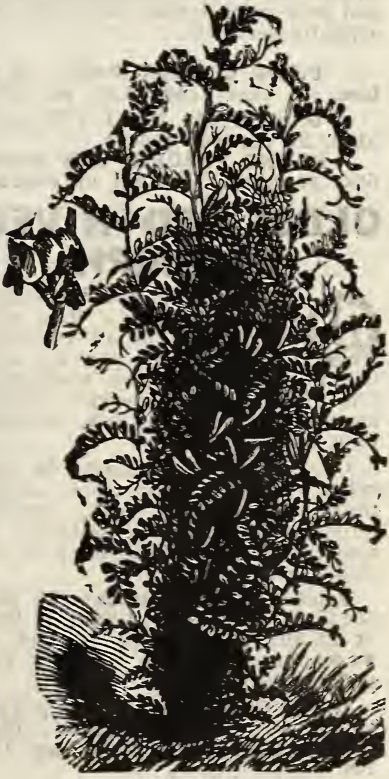

Sand Vetch, 


\section{OLDS' SEED POTATOES}

FORTY YEARS' EXPERIENCE. We began with Seed Potatoes exclusively way back in 1888 . So we have been handling them for 40 years. We have filled orders from nearly every state in the Union and have always ourselves in having the purest, healthiest stock possible to secure.

CERTIFIED STOCK. Most of our potatoes are certified. The early varieties are Red River grown and are Minnesota State Certified, while the late varieties are Northern Wisconsin grown and Wisconsin State Certified, This means in both cases that they were inspected while growing in the field by an official state inspector and again in the bin after being dug and both times passed the necessary requirements. The Minnesota stock bears official blue tags, the Wisconsin stock red tags. The stock is free from mixture, free from late blight rot, black leg, powdery scab and from serious infection with any other disease and conforms reasonably to the correct vine and tuber characteristics of the variety. The stock must be graded to a minimum size of $17 / 8$ inches in diameter for round stock, with not over 5 per cent under size allowed. The Wisconsin Certified stock must also comply with the requirements of "Badger State Brand," under the regulations of the Wisconsin Department of Markets, car inspection being required.

U. S. GOVERNMENT GRADE NO. 1. We offer at lower prices, stock of most varieties that is uncertified, but that conforms to the requirements of U. S. Grade No." 1. That is, stock that is practically free from scab, blight, dry rot and damage caused by disease and graded to a minimum size of $17 / 8$ inches. The stock is all northern grown, coming from the same sections as the certified stock and practically pure. We offer it as very desirable seed stock.

LARGE BARRELS. Our barrels hold exactly 172 pounds each, net weight, the Wisconsin barrel. The old barrel was only 165 pounds, or about 12 pecks by measure. Our prices include barrels. Remember that. Peck and bushel orders are shipped in sacks or in boxes. No charge for containers of any kind for potatoes. We begin shipping, going south, early in March, securing refrigerator service and lining barrels up to April 1st. After that we ship mostly in sacks. The sack is the unit now rather than the barrel, 2 bushel sacks for Red River, $2 \frac{1 / 2}{2}$ bushel sacks for Wisconsin stock.

POTATO PRICES. The prices given in this catalog are good until February 1st only. The chances are that prices will be higher later in the season. The 1927 potato crop was a fairly good one, 400 million bushels as compared with 356 million in 1926, and there will doubtless be potatoes "enough for eating stock, but good seed stock is not so plentiful. This is specially true of certified potatoes. The supply of those is really quite limited. We urge, therefore, early orders. Get them in before stocks are exhausted. Prices right now are certainly low enough and very reasonable, indeed, as compared with last year.

\section{OLDS' RED RIVER IRISH COBBLER.}

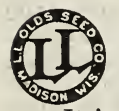

Next to Early Ohio the Most Popular Early Potato.

Irish Cobbler has been for some years the most famous early potato in the East. In the potato sections of $\mathrm{Mrain}$ it has been more largely grown than all other earlies and has been shipped from there in large quantities to supply the truckers of New Jersey and Virginia and other Atlantic coast states. From there its popularity has extended throughout the whole of the United States.

It is a pure white potato, nearly round in shape with eyes rather more pronounced than in the Ohio type varieties.

On our trial grounds Irish Cobbler yielded a third more than Early Ohio, although not quite as early. The potatoes are very attractive looking and of most excellent quality, rather ahead of all other earlies in that respect, always cooking up dry and mealy. This variety will please anyone who wants a few earlies for home use as well as the large grower and the market gardener.

Our Irish Cobblers this year are all Red River grown and we hare Certified Stock as well as uncertified. The uncertified are all U. S. Grade No. 1 and practically pure and free from disease although not officially certified.

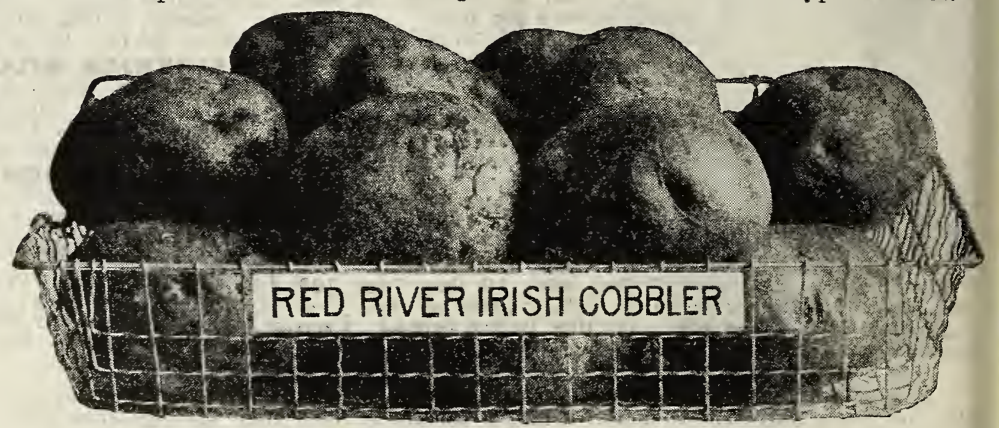

Prices, Certified Stock: $1 / 2$ pk., 45c; pk., 80c; bu., (60 lbs.) $\$ 2.60 ; 2$ bus. at $\$ 2.50 ;$ bbl. (172 lbs.), $\$ 7.35 ; 10$ bus. (in sacks) at $\$ 4.00$ per $100 \mathrm{lbs}$. Barrels and sacks free.

U. S. Grade No. 1 (Uncertified): Pk., 70c; bu., $\$ 2.25 ; 2$ bus. at $\$ 2.15$; bbl., $\$ 6.00$; 10 bus. or over (in sacks) at $\$ 3.25$ per $100 \mathrm{lbs}$.

POUND PRICES. Any variety of potatoes on our list. By mail: One pound (about 3 good tubers), 25c; 3 lbs., 50c, postpaid. Freight or express: Lb., 20c. Not less than one pound of a variety sold.

\section{OLDS' RED RIVER TRIUMPH}

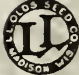

Bliss' Triumph is a standard extra early. The earl. iest in fact of all varieties. ket in the south and southwest. The tubers are nearly round, smooth, medium in size, reddish pink in color.

Our Triumphs cannot be excelled. The illustration shows them just as they look, smooth, uniform, round, very desirable in shape and size. The stock is all Red River grown.

Prices, Certified Stock: $1 / 2 \mathrm{pk}$., $50 \mathrm{c}$; pk., 90c; bu., $\$ 2.90$; 2 bus. at $\$ 2.80$; bbl., $\$ 8.35 ; 10$ bus. at $\$ 4.50$ per 100 lbs. Barrels and sacks free.

U. S. Grade No. 1: pk., 75c; bu., $\$ 2.40 ; 2$ bus. at $\$ 2.30$; bbl., $\$ 6.50 ; 10$ bus. at $\$ 3.50$ per 100 ibs.

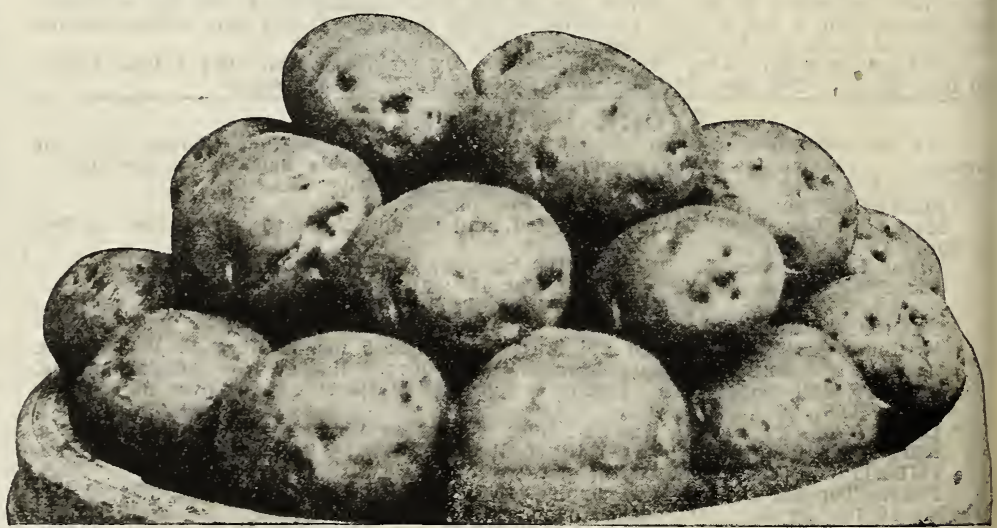

Olds' Red River Triumphs. 


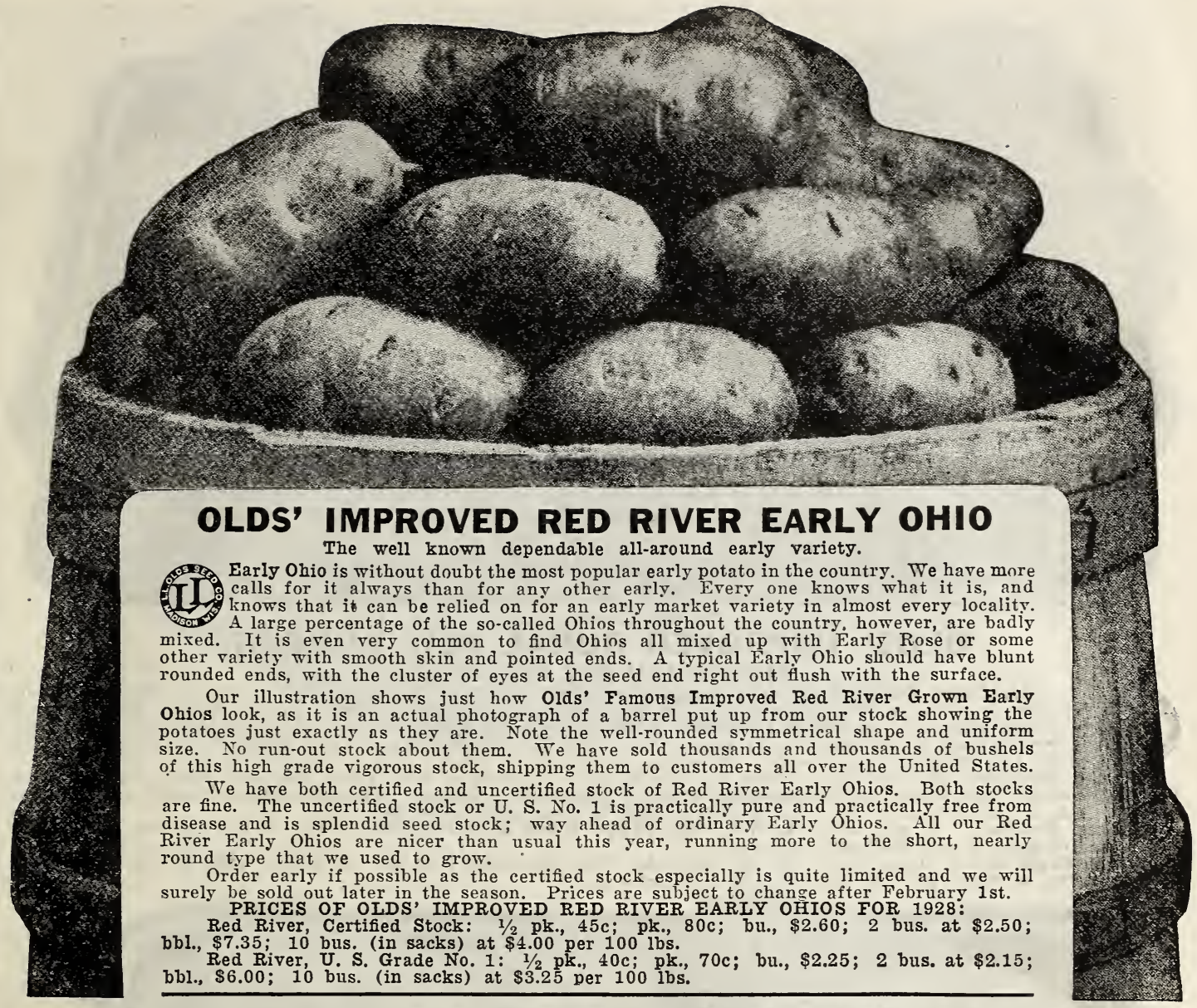

\section{TREAT YOUR SEED POTATOES WITH SEMESAN BEL}

Semesan Bel, the wonderful new Seed Disinfectant, de- pense is very slight as one pound is sufficient for 16 to stroys the diseases which sap the vitality of seed potatoes, gives the seed a chance to germinate quickly and produces sprouts of healthy vigor.

Semesan Bel may be applied by the instantaneous dip method more easily than any other disinfectant. The ex-

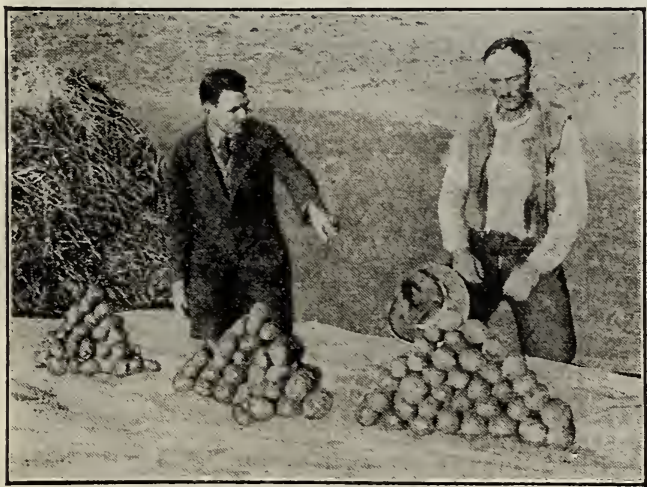

Comparative Yields Prove Semesan's Value.

The left-liand pile represents the rield from three average hills of untreated seed potatoes; the center pile from three hills treated with formaldhyde; and the right from three hills of Semesan disinfected seed. This test was conducted at Ellensburg, Washington. pense is very slight as
20 bushels of potatoes.

Semesan Bel controls scab and rhizoctonia, hastens sprouting, makes a more even stand, improves the quality of the crop and increases the yield. Large potato growers hare reported as high as 43 per cent increase in yield from the use of Semesan Bel.

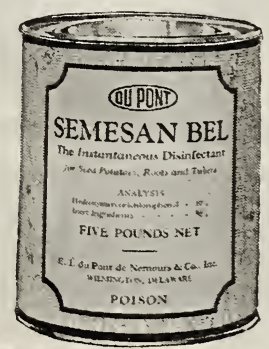

Prices of Semesan Bel:

$1 \mathrm{lb} . \ldots \ldots \ldots \$ 1.75$

5 lbs. ...... 8.00

25 lbs. ...... 37.50

50 lbs. ..... 72.50

100 lbs. .......1 110.00

(Not mailable)

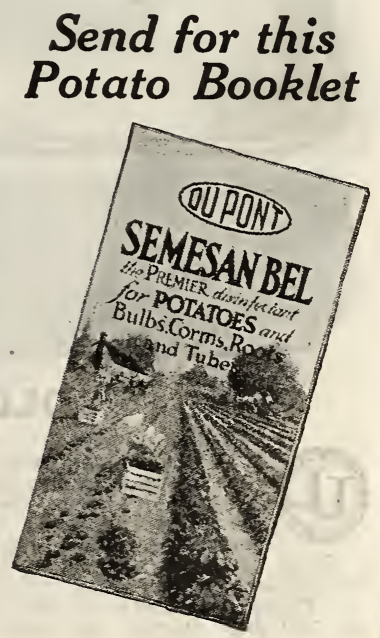




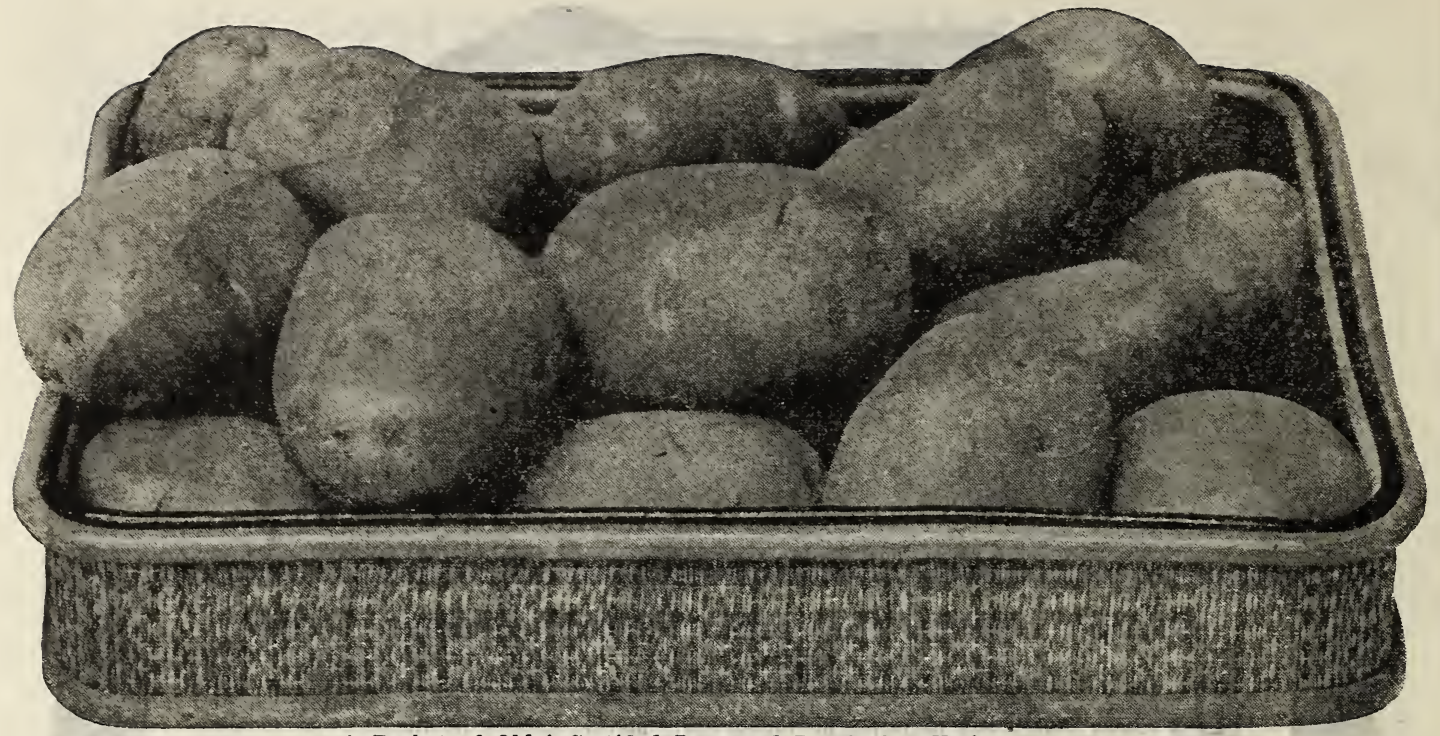

\section{OLDS' IMPROVED RURAL NEW YORKER. \\ THE POTATO FOR EVERYBODY}

Rural New Yorker is the most popular main crop variety in cultivation today. It does the best of any

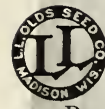
variety as a rule on clay soils and black soils and in fact it is the universal potato for all soils It will probably stand more neglect and do better under unfarorable conditions than any other variety. It is easily grown, a good keeper and always vields well, while its desirable shape, pure white skin annd shallow eyes

make it a good looker and seller. As a rule the quality is all right too.
Rurals throughout the country are badly mixed with other varieties. Such stock does not bring the top price.

We have not only pure Rurals but an improved strain of Rurals, all Northern Wisconsin grown, mostly from Sawyer county. Ask for special prices in large quantities and for new prices after Feb. 1st.

Prices, Certified: $1 / 2$ pk., $40 \mathrm{c} ;$ pk., $75 \mathrm{c} ;$ bu., $\$ 2.50 ; 2$ bus. at $\$ 2.40 ;$ bbl., $\$ 7.00 ; 10$ bus. or over, in sacks, at $\$ 3.75$ per $100 \mathrm{lbs}$. Barrels and sacks included.

U. S. Grade No. 1, Uncertified: $1 / 2$ pk., $40 \mathrm{c} ; \mathrm{pk}$., $70 \mathrm{c}$; bu., $\$ 2.15 ; 2$ bus. at $\$ 2.05 ;$ bbl., $\$ 5.65 ; 10$ bus. or over, in sacks, at $\$ 3.00$ per $100 \mathrm{lbs}$. Barrels and sacks free.
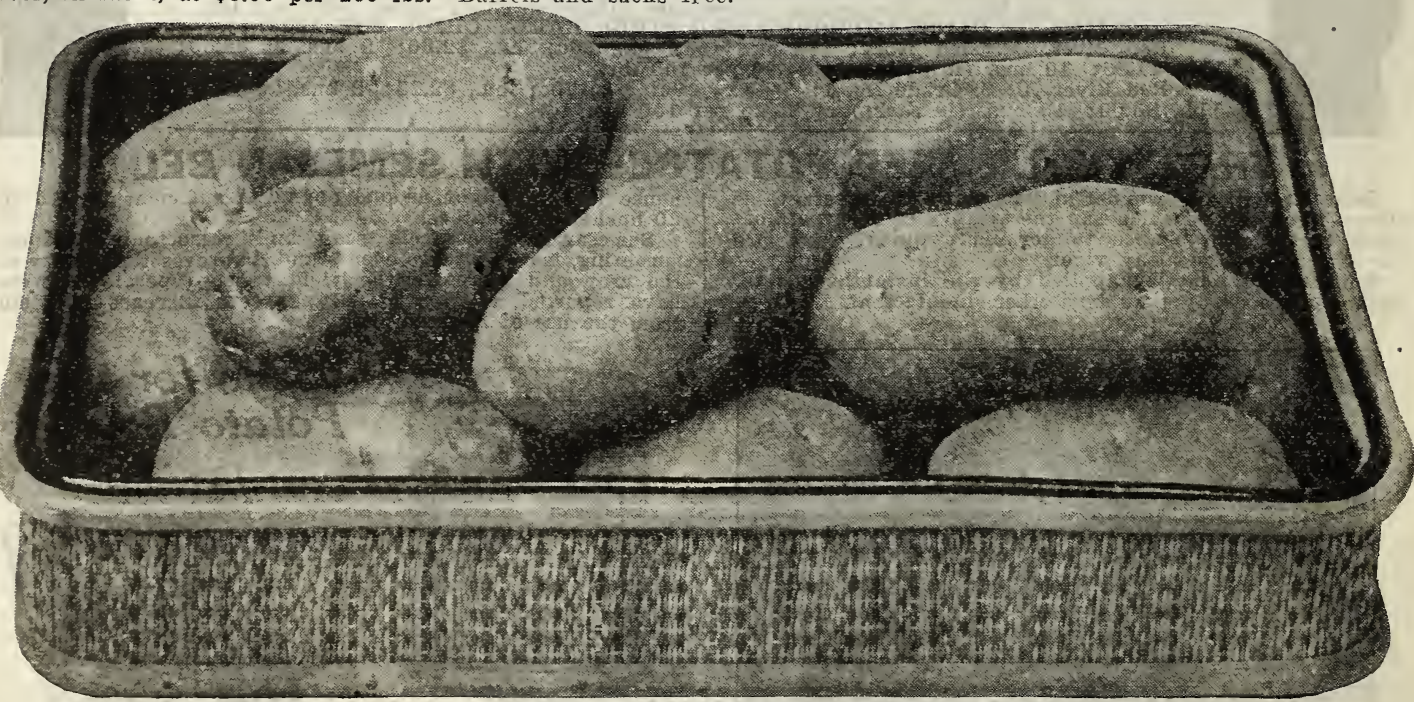

\section{OLDS' IMPROVED GREEN MOUNTAIN}

The Variety for Sandy Soils.

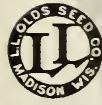

Green Mountain is perhaps the most popular rariets in the

is medium in season. Does specially well on sandy soils. On clay soils is liable to grow rough.
mes

Green Mountain is a vigorous grower with an abundance of bushy vines with light green leaves and pure white blossoms. The tubers are slightly oblong and broad, with a thick netted skin, cream color rather than white. A Green Mountain is hard to beat for an eating potato, as it always cooks up dry and mealy. Our stock is all certified stock and all grown in Northern. Wisconsin. The stock is unusually nice this year.

Prices, Certified: $1 / 2$ pk., $40 \mathrm{c} ;$ pk. $75 \mathrm{c}$; bu., $\$ 2.50 ; 2$ bus. at $\$ 2.40 ;$ bbl., $\$ 7.00 ; 10$ bus, in sacks, at $\$ 3.75$ per 100 lbs, Barrels and sacks free. Ask for special prices in large quantity. 


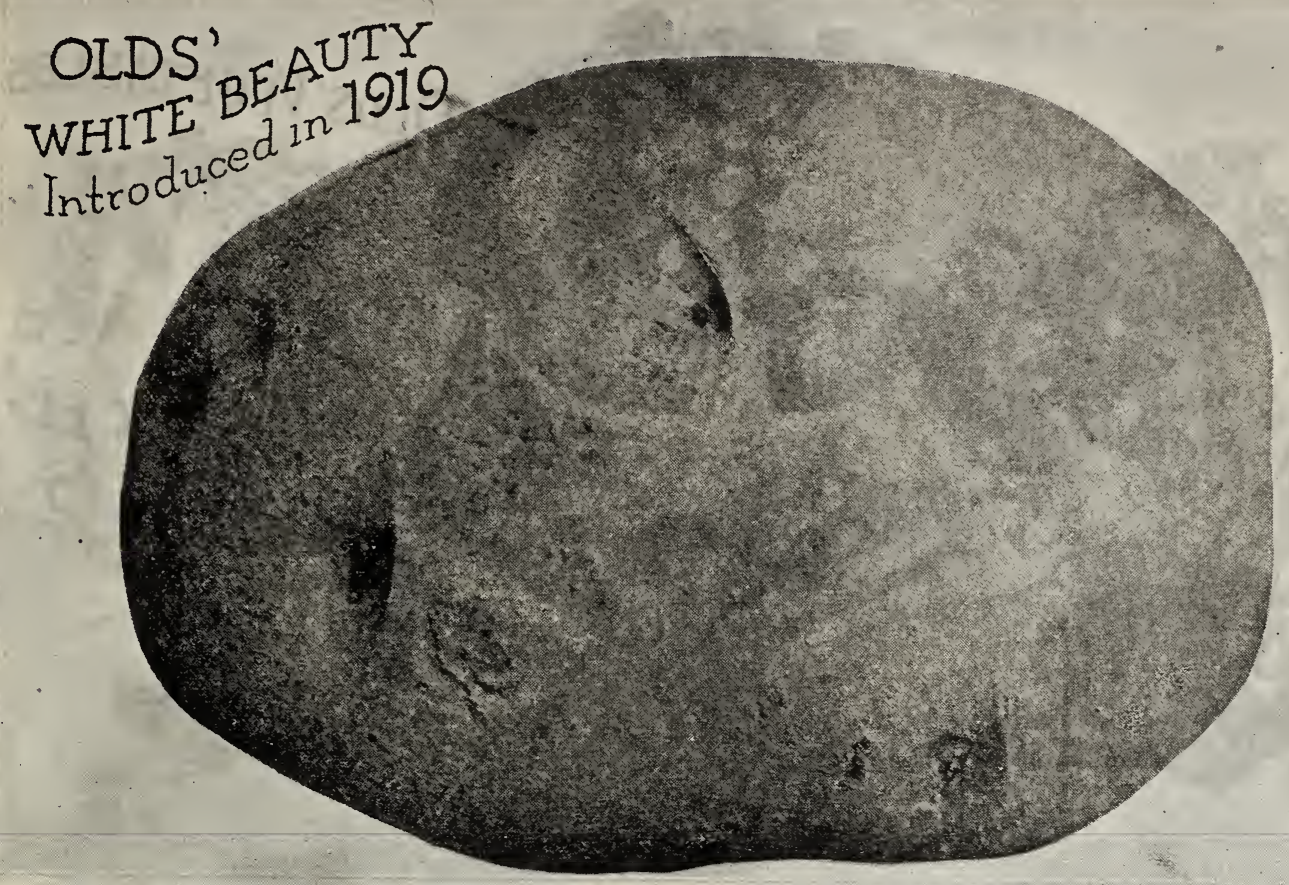

We introduced this potato nine years ago as a strictly new variety that promised to take a place right at the front in the list of valuable potatoes. It is certainly making good. It is a heavy yielding, high quality, main-crop variety. It has a distinct origin starting from a single seed ball in 1911 .

Description. Olds' White Beauty is just the type that is wanted for an all-round, main crop, white-skinned potato. It is the right shape, nearly round to oval oblong; symmetrical and regular in form; eyes very shallow, so shallow that as one of our customers says: "You hardly know they have an eye" ; beautiful white skin, slightly rus. seted: strong, vigorous grower, with dark stalks and purple blossoms. Season medium, a little earlier than Rural.

Value. Olds' White Beauty is a variety of real value. In the first place it can be sold in the large potato markets for Rural New Yorker, the standard main crop variety; but while it resembles Rural it is better. 'I'he color is a creamy white instead of pure white and it is slightly russet like the old Snowflake, indicating quality. Then, for yield it surpasses everything. The North Dakota Experiment Station reported an official yield on it of 466 bushels per acre. On our trial grounds White Beauty outyielded Rural New Yorker, Green Mountain, White Mammoth and Carman No. 3 and the tubers were the finest in appearance of any.

Our White Beauties this year are all Northern Wisconsin grown from Mr. N. B. Dexter, who has furnished us such fine White Beauties in the past. They are not certified because White Beauty is not on the list of recognized varieties in Wisconsin, but they are eligible for certification so far as purity and freedom from disease are concerned.

PRICES OF OLDS' WHITE BEAUTY FOR 1928:

Half pk., $40 \mathrm{c}$; pk., 75c; bu., $\$ 2.50 ; 2$ bus. at $\$ 2.40 ;$ bbl., $\$ 7.00 ; 10$ bus. at $\$ 3.75$ per 100 lbs.

POUND PRICES. Any variety of potatoes on our list. By mail: One pound (about 3 good tubers), 25c; 3 lbs., 50c; postpa1d. By freight or express: Lb., 20c. Not less than one pound of a variety sold.

collection Barrels. We offer a barrel made up of any 2 varieties potatoes on our list, half of each, at barrel rates, plus 20 cents; 3 varieties, at- barrel rates, plus 35 cents. Barrels and sacks are free.

Prices Subject to Change. Prices are in effect untiI February first. Ask for "Weekly Price Iist" after that date.
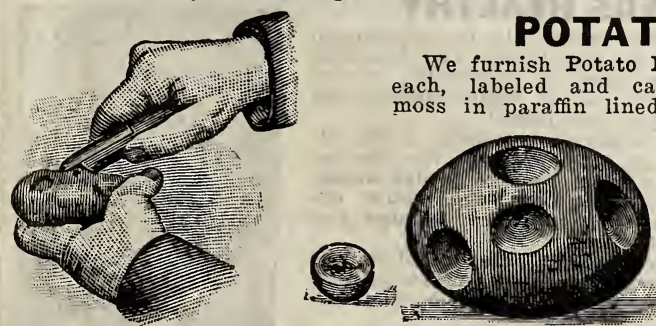

PRICES OF POTATO EYES, ALL VARIETIES.

160 Eyes, (one box) one-variety, your selection, $\$ 1.50$ by mail, postpaid.

160 Eyes, (one box) two varieties, your selection, $\$ 1.60$, postpaid.

160 Eyes, (one box) four varieties, your selection, $\$ 1.70$, postpaid.

480 Eyes, ( 3 boxes) all one variety, $\$ 3.50$ by express, not prepaid.

480 Eyes, ( 3 boxes) three varieties, $\$ 3.75$ by express, not prepaid.

(No orders accepted for less than 160 eyes.)

\section{POTATO BALL SEED.}

Hybridized potato seed from the balls.

Every seed makes a distinct variety.

Pkt., $15 \mathrm{c}$; 2 pkts., $25 \mathrm{c}$, postpaid.

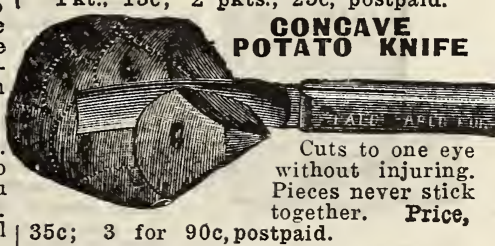

\section{OTATO FERTILIZERS}

It will pay you well to use Commercial Fertilizers for your potatoes. That is the way big yields of fine tubers are secured. We recommend either 4-8-6, "Truck Gardeners' Special" or 2-12-6, "Tobacco and Beet Grower." See page 92. Ask for bulletin, "Fertilizing Potatoes." 


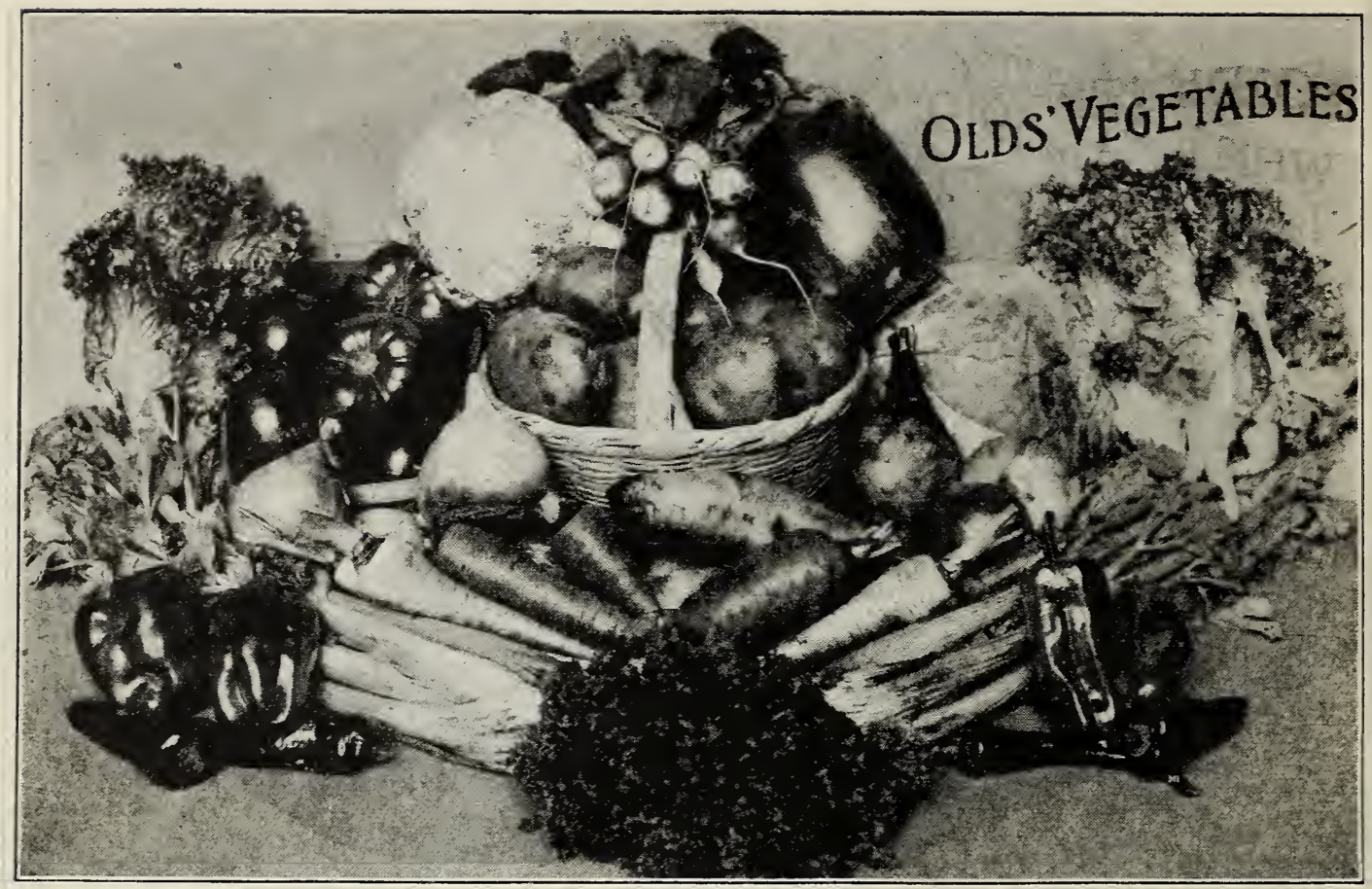

\section{OLDS’ GARDEN SEEDS}

HIGH QUALITY SEEDS. Our Garden Seeds are good seeds. There are none better. Other eatalogs may use more superlatives and show more colored pictures but their seeds come from the same sources as ours as practically all the Garden Seeds in the United States are grown by a $f_{e w}$ expert growers, different ones specializing in certain things and growing them in large quantities in the sections where they can be produced in the highest perfection.

TESTED SEEDS. We test carefully for germination every lot of seed as it comes in, discarding any lots that do not come up to the Wisconsin standard.

Most every farmer in Wisconsin, at least, knows that our state has a wonderfully effective seed law. But it is not generally known that this law includes Garden Seeds, as well as Field Seeds, so far as germination is concerned. That is, high standards of germination are established by the law for the different kinds of vegetable seeds and if any lot of seeds falls below the standard set the percentage of germination must show on the package. This insures high test. ing seed, as no seed house wants to send out seeds showing a low test on the package.

GUARANTEED SEEDS. See what we say about guaranteeing quality on page one. Our seeds must prove as represented. If they do not $w$ e refill or refund.

STARRED VARIETIES. Varieties marked with a star are those that we specially recommend for general cultiva. tion. Where our Trade Mark appears it indicates varieties that we have been instrumental in introducing.

POSTPAID PRICES. Our prices on Vegetable Seeds, Flower Seeds, Bulbs and Plants include free delivery to any Post Office in the Lnited States, unless otherwise stated. See tables of freight and parcel post rates on page one.

LARGE PACKETS. All our packets of Beans, Peas, Sweet Corn and Pop Corn contain two ounces each. Some of our competitors will give you only one ounce in a packet. Our other vegetable seed packets are unusually large, four to the ounce of most of the standard regetables.

COLLECTION OFFERS. We sell 30 regular packets of standard varieties of vegetables for One Dollar Postpaid. See back corer. Note also our wonderful Gladiolus and Dahlia Collection offers on the colored pages.

MARKFT GARDENERS' PRICE LIST; If you are a market gardener and use seeds in large quantity ask for our "Market Gardeners' Wholesale Price Iist." It will save you money.

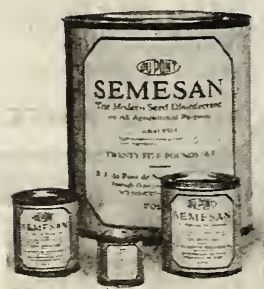

PRICES OF SEMESAN: 2 ozs., $50 \mathrm{c} ; 8$ ozs., $\$ 1.60 ; 1$ lb., $\$ 2.75 ; 5$ lbs., $\$ 13.00$; 25 lbs., $\$ 62.50$; 50

lbs., $\$ 122.50$.

(Not mailable.)

\section{SEMESAN MAKES SEEDS HEALTHY}

"Seed Disinfection" is the modern slogan. It is well known now that there are a great many seed borne fungous and bacterial diseases that cut down yields unless destroyed or controlled. Semesan, the wonderful new seed disinfectant, can be easily applied and the cost is very slight, $1 / 4$ cent to one cent per pound.

Semesan produces results with all kinds of vegetable crops, increasing vields in some cases as high as 33 per cent. Specific reports have come in from large growers of such crops as garden beans, cabbage, cauliflower, celery, cucumbers, sweet corn, egg plants, on ions, peas, peppers, melons, spinach, squash, tomatoes, turnips and in fact nearly everything in the vegetable line.

One bean grower writes: "We treated 150 acres of stringless hean seed with Semesan and had the largest crop of our experience. In many cases the treated seed yielded as high as 20 bushels per acre more." Roy I. Shaw, Twin Falls, Idaho, writes: "My neighbor planted the same rariety at the same time on just as good soil as my own. My Semesan-treated peas were away ahead of his at all stages and matured fully ten days sooner. Believe from appearance of the two patches that I had twice as large a vield."

Semesan is recommended by Government Experts, Agricultural Colleges, County Agents and large growers in erery section of the country. You should be using this effective crop protection.

Ask for book, "Semesan Produces More and Finer Vegetables."

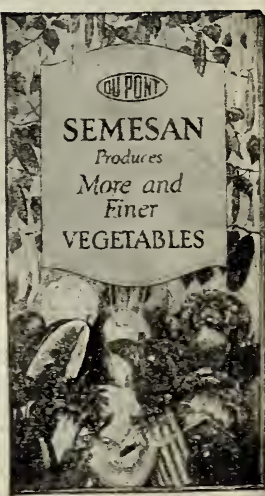




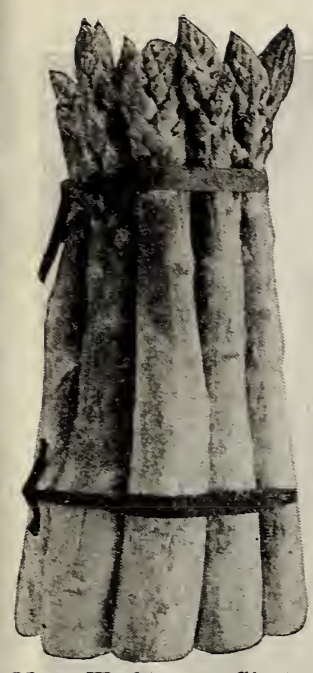

Mary Washington Giant

\section{ASPARAGUS OLDS' ASPARAGUS PLANTS}

The growing of asparagus plants is one of our specialties. On our orn farm where the rich, loose soil seems to be particularly adapted to making strong root growths, we have thousands of the very best plants that can possibly be produced. An asparagus bed is a sort of permanent affair, the arerage life of which is about fifteen to twenty years so in starting a new bed it is important to obtain the rery best.

The Mary Washington Giant Rust Proof is our main rariety. We have been growing the plants for several sears and we have them in both one and two-year-old sizes.

6. . MARY WASHINGTON GIANT RUST PROOF. The result of years of breeding and selecting by the United States Bureau of Plant Industry. The stalks are larger and more tender than those of other varieties, and apparently immune from rust. Mary Washington asparagus will meet the needs of both market gardeners and home gardeners.

Seed: Pkt., 10c; oz., 30c; 1/4 lb., 90c; 1b., \$3.00. Plants-One year old, 25 for $75 \mathrm{c}$; 50 for $\$ 1.25 ; 100$ for $\$ 2.00$. Two year old, 25 for $\$ 1.00 ; 50$ for $\$ 1.75 ; 100$ for $\$ 2.50$ postpaid. Not prepaid, one year old, 100 for $\$ 1.75 ; 1,000$ for $\$ 11.00$. Two years, not prepaid, 100 for $\$ 2.25 ; 1,000$ for 15,$00 ; 500$ at the 1,000 rate.

(T)e recommend One Year Plants in preference to Two Year. They are cheaper, they are more easily planted because of having shorter roots and after the first year they will

produce more.) thick shoots are white and remain so. Pkt., 10c; oz., 15c; 1/4 1b., 35c; lb., \$1.00, postpaid. Plants, one year old, 25 for $45 \mathrm{c} ; 100$ for $\$ 1.60$. Twa year old, 25 for $75 \mathrm{c} ; 100$ for $\$ 2.00$, prepaid. Not prepaid, one year, 1,000 for $\$ 7.50$; two year, 1,000 for $\$ 10.00 ; 500$ at the 1,000 rate.

5. PALMETTO. A very heavy grower. Shoots large, dark green, with pointed tips. Prices same as for Columbian Mammoth White.

\section{BRUSSELS SPROUTS.}

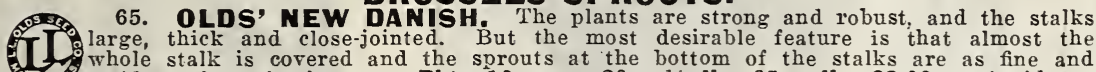
whole stalk is covered and the sprouts at the bottom of the stalks are as fine
solid as those further up. Pkt., 10c; oz., 20c; $1 / 41 \mathrm{~b}, 65 \mathrm{c} ; 1 \mathrm{~b}$., $\$ 2.00$, postpaid.

\section{BEANS - WAX POD BUSH}

Every one of our bean packets contains full two ounces and will plant 10 to 15 feet of drill. A pound of beans will plant 75 to 100 feet. An acre requires 1 to $1 \frac{1 / 2}{2}$ bush els. Use Nitragin or Old Gold Inoculation on the seed.

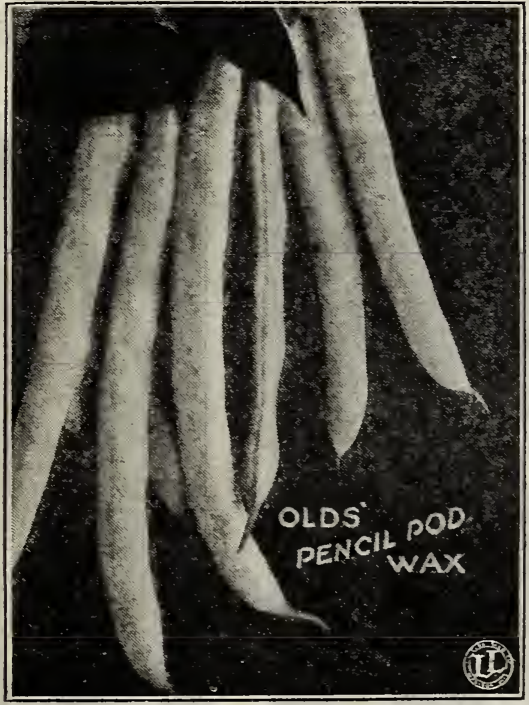

24. ŁOLDS' PENCIL POD BLACK WAX. Best of all the dwarf black-seeded wax varieties. A long, straight, round-podded, crease-back bean. Early and very productive: entirely stringless and a clear yellow in color. It is good as a canning variety on account of its solidity, and wonderfully fine for the home garden. Large 2 oz. pkt., $10 \mathrm{c}$; $1 / 2 \mathrm{lb}, 40 \mathrm{c} ; 2$ lbs., $70 \mathrm{c}$; 5 lbs., $\$ 1.40$, postpaid. Not prepaid, $10 \mathrm{lbs}$. or more at 21c.

22. DAVIS WHITE KIDNEY WAX. While belonging to the wax or yellow class the Daris is lighter in color. The pods are long, white, straight, flat and tender and are borne in clusters. It is in the first early class and a rery handsome bean. Primarily a market gardener's rariety. Pkt., $10 \mathrm{c}$; $1 / 2 \mathrm{lb} ., 25 \mathrm{c}$; lb., $40 \mathrm{c} ; 2 \mathrm{lbs}$., $70 \mathrm{c}$, post. paid. Not prepaid, $10 \mathrm{lbs}$. or more at $20 \mathrm{c}$.

26. WEBBER WAX. (Cracker Jack Wax.) A high quality, flat podded, stringless variety, very attractive in appearance. Pods bright yellow, 6 to $61 / 2$ inches long and quite broad. Hardy and very prolific. Very desirable for market gardeners. Seed vellow, kidney shaped. Pkt., $10 \mathrm{c} ; 1 / 2$ lb., 20c; lb., 35c; 2 lbs., $60 \mathrm{c}$, postpaid. Not prepaid, $10 \mathrm{lbs}$. or more at $19 \mathrm{c}$.

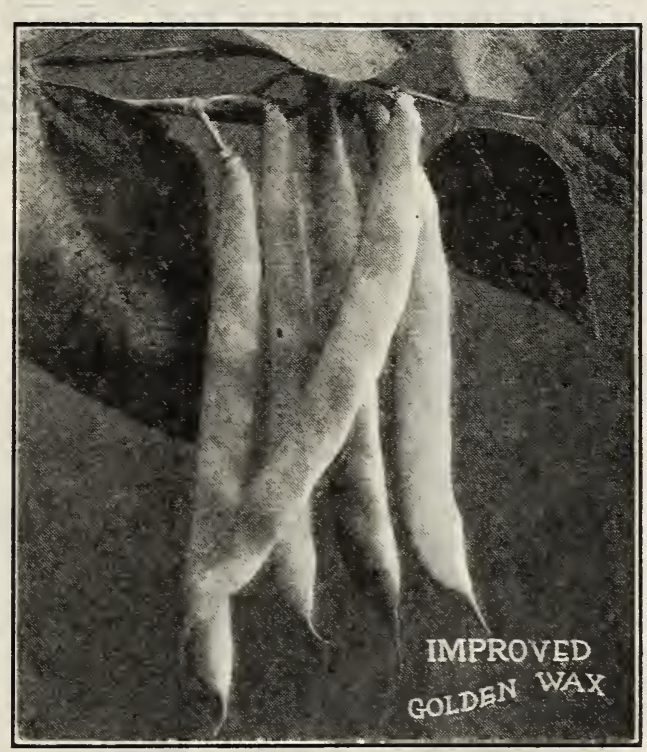

20. ^IMPROVED GOLDEN WAX. The standard flat, wax-podded rarietr. The Golden Wax has long been a popular farorite and this Improved strain surpasses the old Golden Wax in sereral ways. The plants are rery bushy and not susceptible to blight. The pods are large and handsome-they are also tender, brittle and string. less; of a rich golden-vellow color. This and our Pencil Pod Black Wax are our leaders in wax pod rarieties for the home garden. Large 2 oz. pkt., $10 \mathrm{c}$; $1 / 2$ lb., $25 \mathrm{c}$; 1b., $40 \mathrm{c}$; 2 lbs., 70c; 5 lbs., $\$ 1.40$, postpaid. Not prepaid, $10 \mathrm{lbs}$. or more at $20 \mathrm{c}$.

19 1/2. OLDS' LATE STRINGLESS WAX. Our introduction of 1921. A selection from Buryellow podded variety. Very fine for quality, absolutely stringless and rery productive. Not extra late but later than Olds' Early Stringless Wax. Crop short. Pkt., 10c; $1 / 2$ Ib., 30c; lb., $50 \mathrm{c}$; 2 lbs., 90c, postpaid.

201/2. OLDS' EARLY STRINGLESS WAX. Crop 


\section{BEANS-GREEN POD}

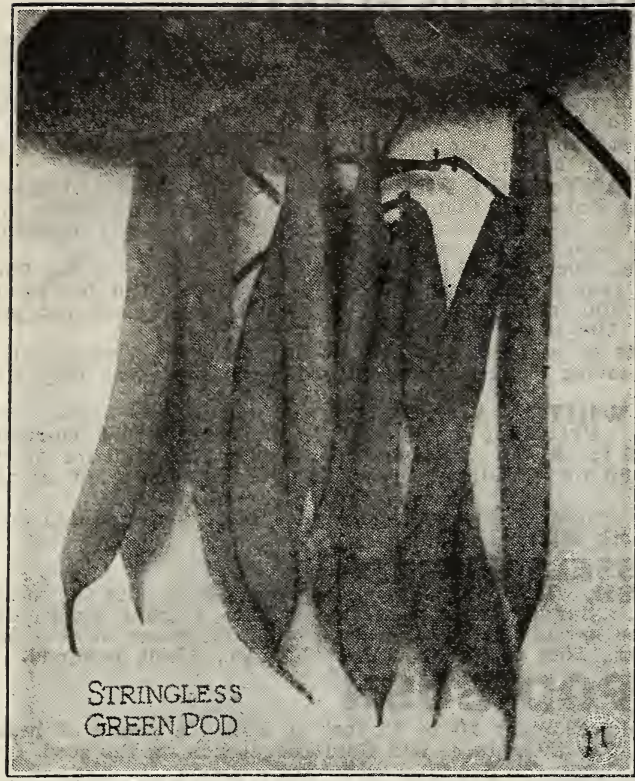

15. †STRINGLESS GREEN POD. (Burpee's.) The best green pod. A bush or dwarf variety It is early, hardy and productive, bearing handsome pods which are entirely stringless even when fully matured. The pods are five or more inches long, very round and straight. We recommend this variety above all others if a green pod is wanted. Large 2 oz. pkt., 10c; 1/2 1b., 25c; 1b., 40c; 2 lbs., $70 \mathrm{c} ; 5$ lbs., $\$ 1.40$, postpaid. Not prepaid, $10 \mathrm{lbs}$. or more at $19 c$

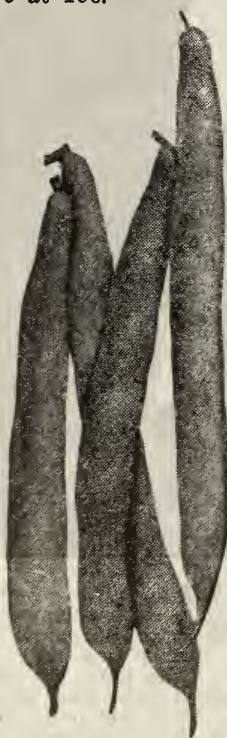

Bountiful.

13. BOUNTIFUL. The best green pod bush in our judgment next to Stringless Green Pod. The pods are flat instead of round, stringless, attractive and of good quality. Early, hardy and very productive. Pkt., $10 \mathrm{c}$ $1 / 2$ 1b. 25c; 1b., $45 c$; 2 lbs. $80 \mathrm{c}$, postpaid. Not prepaid. 10 lbs. or more at $22 \mathrm{c}$.

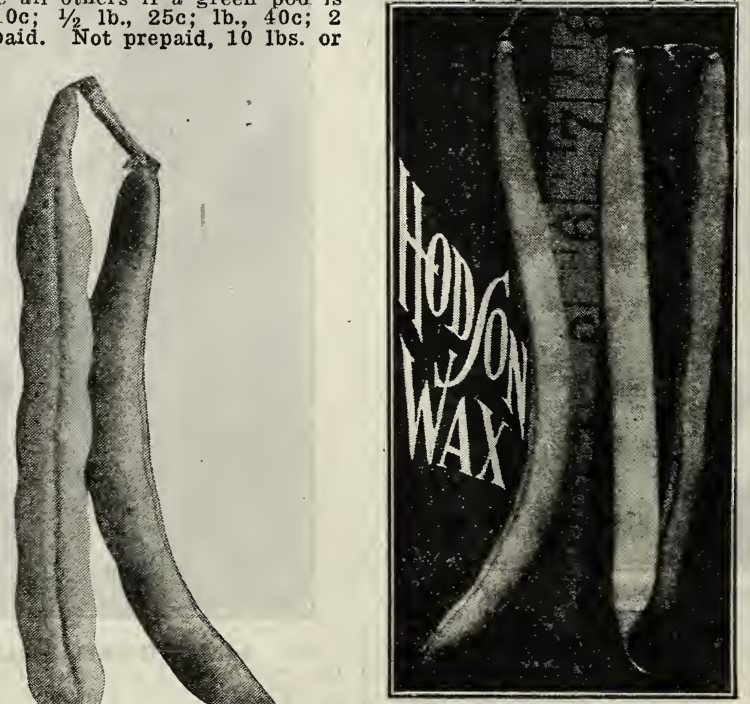
EARLY RED VALEN. TINE (Round Pod). A green pod bush variety, early hardy, productive, Pods round, crease-backed. An old favorite. Pkt., 10c; $1 / 2$ 1b., 20c; 1b, 35c; 2 Ibs., $60 c$ postpaid. Not prepaid, 10 lbs. at $17 \mathrm{c}$ (old Homestead.)

Without doubt the most popular and useful of the green most widely grown. Lender, very fleshy and of fine quality. Large oz. pkt., 10c; 1/2 lb., 20c; lb., 35c; 2 lbs., 60c; 5 lbs. $\$ 1.20$. postpaid. Not prepaid, io $\mathrm{lbs}$. or more at $18 \mathrm{c}$.
27. HODSON WAX Another bush wax pod variety. Noted for its very large, flat, attractive looking pods, usually measuring 6 to 8 inches long. Very productive but rather late. Pkt., 10c; $1 / 21 b ., 20 \mathrm{c}$; 1b. $35 \mathrm{c} ; 2$ lbs., $60 \mathrm{c}$; postpaid. Not prepaid, $10 \mathrm{lbs}$. at $19 \mathrm{c}$.

\section{MARKET}

GARDENERS

Do not fail to secure a copy of our "Market Gardeners' Wholesale Price Iist."

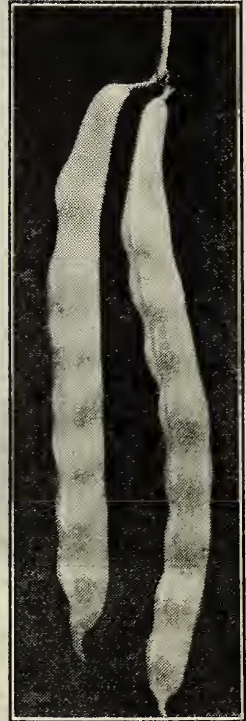

Kentucky Wonder Wax. $381 \frac{1}{2}$. K ENT U G K Y WONDER WAX.

early Pole Wax sort; pods 8 to 9 inches long thick. Pkt. 10c; $1 / 2$ lb., 25c; lb., $40 \mathrm{c}$; 2 lbs., $70 \mathrm{c}$, postpaid. Not prepaid, 10 lbs. at $20 \mathrm{c}$ 19. REFUGEE OR THOUSAND - TO-ONE. A very productive, hardy vigorous, late green pod bush variety. Pkt., 5c; $1 / 2$ $1 \mathrm{~b}, 15 \mathrm{c}$; 1b. 25c; 2 lbs. $45 \mathrm{c}$, postpaid. Not prepaid, $10 \mathrm{lbs}$. or over, at $15 \mathrm{c}$. 


\section{BEANS-LIMA}

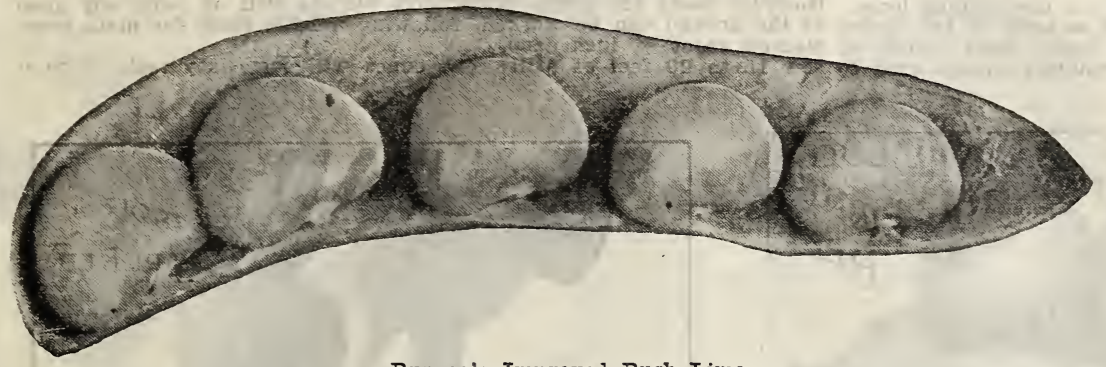

Burpee's Improved Bush Lima.

31. ^BURPEE'S IMPROVED BUSH LIMA. Early, large and productire. Both beans and pods are larger than in the old type, usually areraging one more bean to the pod. Also earlier. The bush is vigorous in growth, upright and has a heary foliage. Pods are uniform in size, with an arerage of fire beans to a pod. Beans are large, thin skinned and of fine flavor. The pods are borne in clusters and are easily gathered. There is nothing quite so delicious as green Lima beans fresh from rour garden. Large $2 \mathrm{oz}$. pkt., 10c; 1/2 lb., 25c; lb., $45 \mathrm{c} ; 2 \mathrm{lbs}$., $80 \mathrm{c} ; 5 \mathrm{lbs}$., $\$ 1.60$, postpaid. Not prepaid, $10 \mathrm{lbs}$. or more at $22 \mathrm{c}$.

31. HENDERSON'S BUSH LIMA. A small bean. The bush is not as large, but it is earlier than any other Bush Lima. Pods are small, containing. 3 or 4 small, flat, white beans of good quality. A popular variety with canners. It is like the Golden Bantam Corn in that it is small, early and very good. Pkt., $10 \mathrm{c} ; 1 / 2 \mathrm{lb} ., 20 \mathrm{c} ; 1 \mathrm{~b} ., 35 \mathrm{c} ; 2 \mathrm{lbs}$., $60 \mathrm{c} ; 5 \mathrm{lbs}$., $\$ 1.20$, postpaid. Not prepaid, $10 \mathrm{lbs}$. or more at $17 \mathrm{c}$.

33. FORD'S MAMMOTH PODDED. The largest podded, finest flavored and most productive Pole Lima Bean. The pods arerage eight inches in length, with from fire to seven beans in a pod, excellent for use, green or drr. The rines grow vigorousls, set the beans early, and continue to bear until frost. Pkt., $10 \mathrm{c}$; 1/2 1b., $25 \mathrm{c}$; 1b., $45 \mathrm{c} ; 2 \mathrm{lbs}$., $80 \mathrm{c}$, postpaid. Not prepaid, $10 \mathrm{lbs}$. or more at $21 \mathrm{c}$.

301\%. DREERS POLE LIMA. This rariety of lima is desirable on account of earliness and productiveness. The plants are rigorous and corered with large pods. The beans are oral in shape, thick, sweet and succulent. Pkt., 10c; 1/2 1b., 25c; 1b., 40c; 2 lbs., $70 \mathrm{c}$, postpaid. Not prepaid, $10 \mathrm{lbs}$. or more at $20 \mathrm{c}$.

39. SGARLET RUNNER. A pole bean that is really a climbing bean and very ornamental. The blossoms are purple or scarlet, the pods a beautiful green, shading to wine color when ripe. The large, showy leares are about the same color. Seed reddish brown, mottled black. Planted mostiy for ornamental purposes but the beans are good to eat, both as snap and shelled beans. Pkt., 10c; 1/2 1b., 20c; 1b., 35c; 2 lbs., 60c, postpaid. Not prepaid, $101 \mathrm{bs}$. or more at $19 \mathrm{c}$.

14. NAVY BEAN or BOSTON BAKED BEAN, as it is sometimes called. Popular since the time of the Ciril War. Don't gire it rich soil. Cultivate well, but nerer cultirate or disturb any crop of beans while wet with either dew or rain, as it is alwars sure to produce rust or blight. Pkt., $5 \mathrm{c}$; $1 / 2 \mathrm{lb}$., $15 \mathrm{c}$; 1b., $25 \mathrm{c}$; 2 lbs., $50 \mathrm{c} ; 5 \mathrm{lbs}$., $\$ 1.00$, postpaid. Not prepaid, $10 \mathrm{lbs}$. at $10 \mathrm{c}$.

We hare a good recipe for BOSTON BAKED BEANS free for the asking.

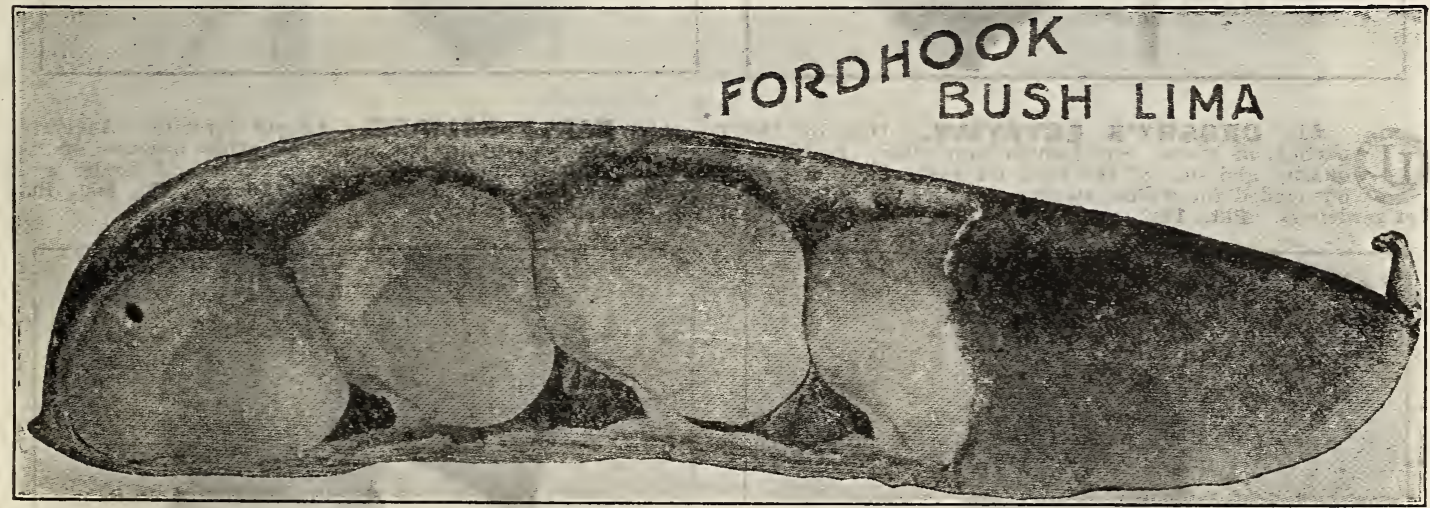

341/2. FORDHOOK BUSH LIMA. The highest in quality and the most prolific of all the Bush Iima Beans. An improved variety with plants growing erect and bearing well above the ground. Pods are medium green in color; from four to five inches long, and produced in large clusters; they contain from 3 to 5 large beans each and are of fine quality. The beans are white, with greenish tinge, thick and meaty. Large 2 oz. pkt., 10c; 1/2 lb., 30c; 1b., $50 \mathrm{c} ; 2 \mathrm{lbs}$., $90 \mathrm{c} ; 5 \mathrm{lbs}$., $\$ 1.80$, postpaid. Not prepaid, $10 \mathrm{lbs}$. or more at $27 \mathrm{c}$. and make this legume enrich the soil in which it is used. Once tried on garden beans you will always use it. It pays for itself ten times orer. It is not an expense but an inrestment. Price, Garden Size, suffient for 8 pounds, 22 , postpaid. Not prepaid, 20c. (The same culture mas be used for Peas also.) 


\section{BEETS}

The best soil for beets is a deep, sandy loam. However beets are easily grown and will do well on most any good soil. For early beets, plant as early in the spring as the ground can be worked, following a little later for main crop. For winter beets, plant in June. Seed should be planted about $3 / 4$ inch deep.

Each of our packets contains enough seed to sow 15 to 20 feet of drill; one ounce will sow sixty feet; 5 to 6 pounds an acre in drills.
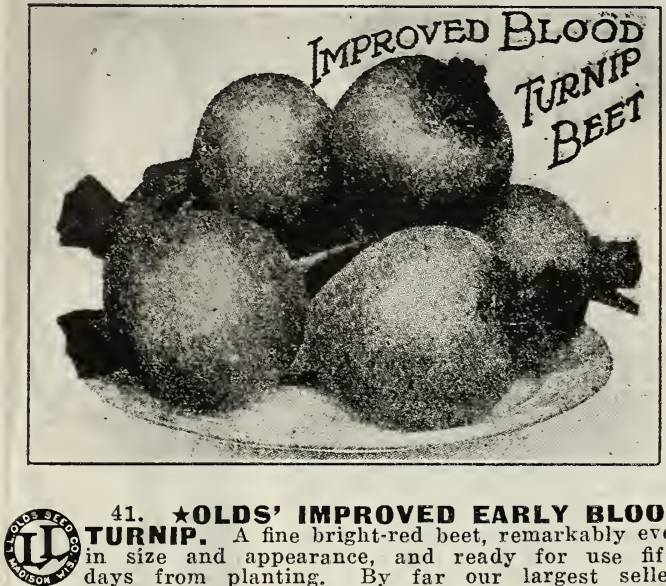

41. †OLDS' IMPROVED EARLY BLOOD TURNIP. A fine bright-red beet, remarkably even in size and appearance, and ready for use fifty Pkt., 10c; 0z., 15c; 1/4 lb., 35c; 1b., \$1.10, postpaid.

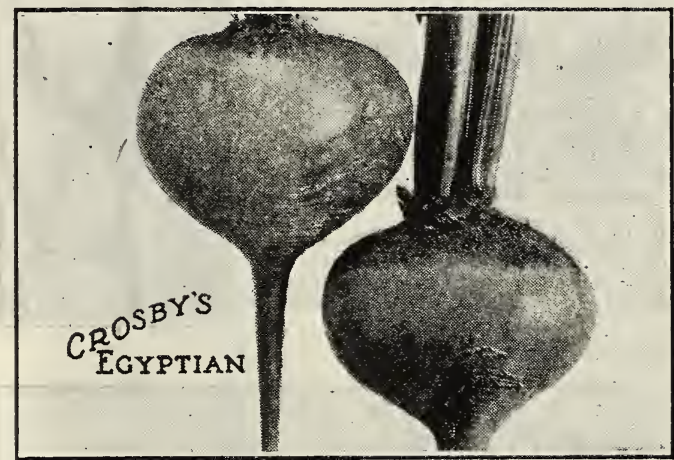

51. GROSBY'S EGYPTIAN. One of the

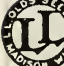
earliest of beets. Good shape and color Excellent quality and one of the best for early but not recommended for winter storing. A favorite with mar ket gardeners. Pkt., 10c; oz., 15c; 1/4 Ib., 35c; 1b., $\$ 1.10$.
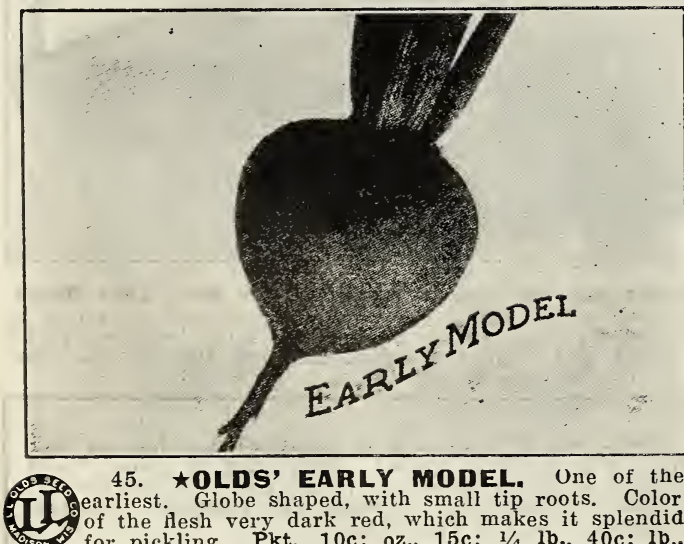

45. TOLDS' EARLY MODEL One of the earliest. Globe shaped, with small tip roots. Color of the Hesh very dark red, which makes it splendid for pickling. Pkt., 10c; oz., 15c; 1/4 lb., 40c; 1b., $\$ 1.25$, postpaid.

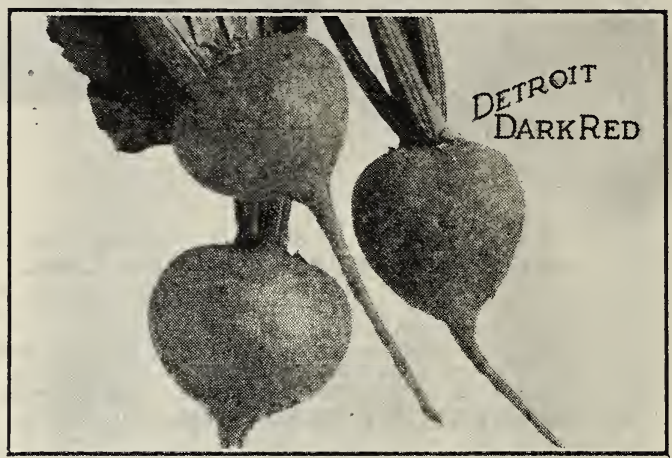

48. ADETROIT DARK RED. A leader for both home and market garden. Globe shaped, smooth and symmetrical. Dark crimson in color. Quality the best. Probably the most widely grown beet for commercial canning. Pkt., 10c; oz., 15c; 1/4 1b., 35c; lb., \$1.15, postpaid.

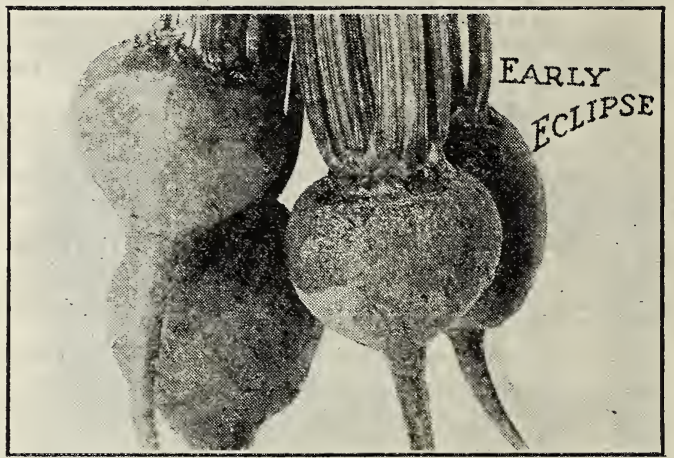

44. EARLY ECLIPSE. An old favorite. As early as Crosby's Egyptian but more desirable because of its perfect globe shape. Very smooth, sweet and tender and bright red in color. Pkt., 5c; 0z., 10c; 1/4 1b., 30c; lb., $90 \mathrm{c}$, postpaid.

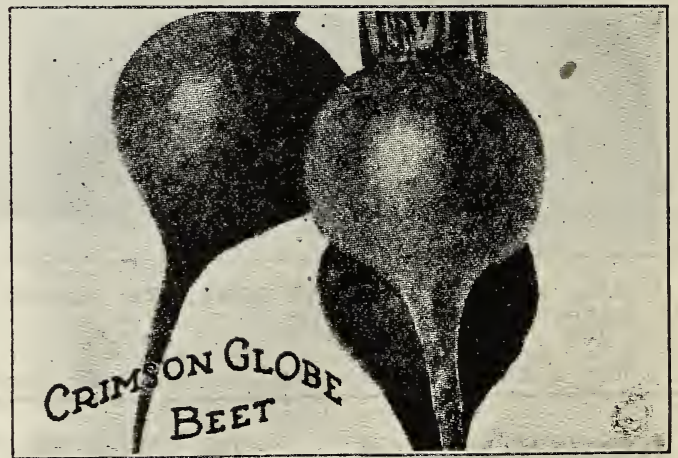

52. †CRHASON GLOBE.. A very fine late or main crop table and market variety. Medium in size, handsome, with small dark foliage. Unequalled for table use. Pkt., 5c; oz., 10c; 1/4 lb., 30c; lb., 85c, postpaid. 


\section{BEETS}

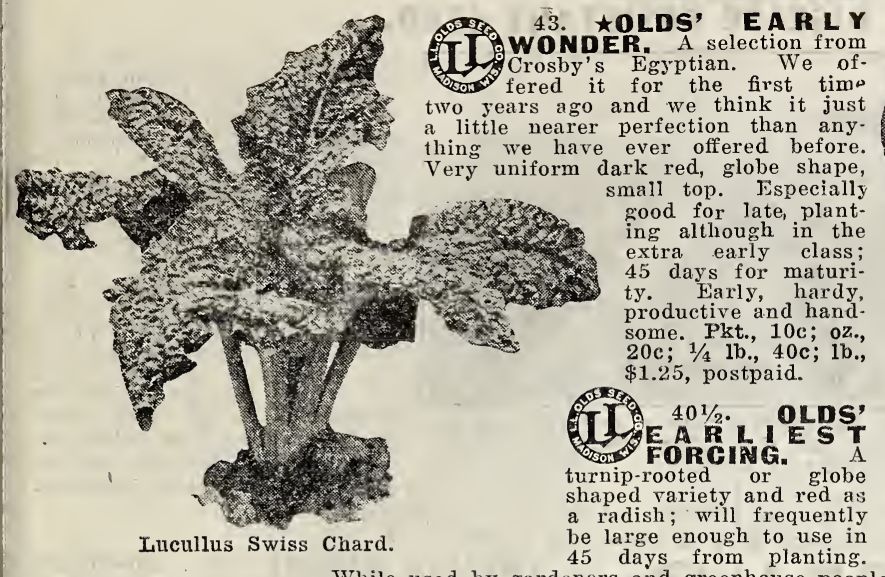

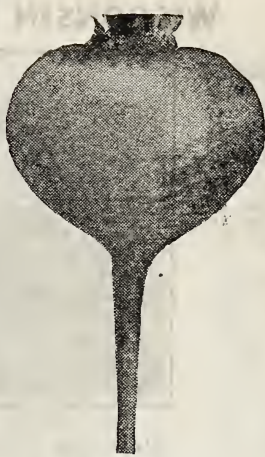

Early Wonder.

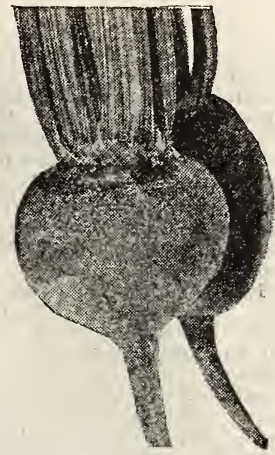

Earliest Forcing.

While used by gardeners and greenhouse people for a forcing variety, it is just as good out of doors for early use. This is probably the earliest beet of all. Pkt., 10c; oz., 20c; 1/4 1b., 40c; lb., \$1.25, postpaid.

40. EXTRA EARLY EGYPTIAN, One of the very earliest, with small top. Roots flat. Very dark red. Flesh dark, purplish red. Pkt., 5c; oz., 10c; 1/4 lb., 30c; lb., 85c, postpaid.

$52 \frac{1}{2}$. LUOULLUS SWISS CHARD. The best variety of Swiss Chard. The crisp, tender, crumpled leaves. are cooked like spinach and are finer flavored. The stalks are prepared like asparagus. Very prolific and good all summer. Pkt., 10c; 0z., 15c; 1/4 1b., 40c; 1b., $\$ 1.25$, postpaid.

\section{MANGELS AND SUGAR BEETS.}

Highly nutritious and easily stored for winter. Greatly relished by all kinds of live stock. One ounce sows 75 to 100 feet of drill. Five pounds sows an acre. Yields of 15 to 20 tons of roots per acre are not unusual. A cheap feed.

59. GIANT EGKENDORF. A wonderfully fine mangel containing a large amount of nutritive matter. A tremendously heavy yielder. The immense roots often weigh from is to 20 pounds each. Oz., 10c; 1/4 lb., 20c; 1b., 60c; 5 lbs., $\$ 2.65$, postpaid. Not prepaid, 10 lbs. or more at $45 \mathrm{c}$.

55. „MAMMOTH LONG RED. The heaviest cropping and largest of all mangels, and the most widely grown. The roots frequently grow two feet or more long, with $1 / 2$ to $2 / 3$ of their length above ground Skin bright red; flesh white with rings of pink. Oz., $10 \mathrm{c}$; $1 / 4$ lb., $20 \mathrm{c}$; lb., $60 \mathrm{c} ; 5$ lbs., $\$ 2.65$, postpaid. Not prepaid, $10 \mathrm{lbs}$. or more at $45 \mathrm{c}$.

$59 \frac{1}{2}$. $\quad$ \DANISH SLUDSTRUP. This new mangel has attaned the higli: est honor in agricultural circles in Denmark wlere mancels are as important as corn is here. Sludstrup has a long reddish-yellow root, growing more than half above ground; is easily harvested. It excels any other variety in weight feed. ing value, and yield. Oz., 10c; $1 / 4 \mathrm{lb}$., $25 \mathrm{c}$; lb., 75c; 5 lbs., $\$ 3.00$, postpaid. Not prepaid, $10 \mathrm{lbs}$. or more at $50 \mathrm{c}$.

56. GOLDEN TANKARD. The best yellow-fleshed mangel. Contains a larger percentage of sugar than the red mangels. Can be grown closely in rows and yields enormously. Oz., 10c; 1/4 lb., 20c; lb., 60c; 5 lbs., $\$ 2.65$, postpaid. Not prepaid, $10 \mathrm{lbs}$. or more at $45 \mathrm{c}$.

63. GIANT HALF.SUGAR BEET Combines the large size of the mangel with the great feeding value of the sugar beet. Oz., 10c; $1 / 4$ 1b., $20 \mathrm{c}$; 1b., $65 \mathrm{c} ; 5$ lbs., $\$ 2.90$, postpaid. 'Not prepaid, 10 lbs. or more at $50 \mathrm{c}$

61. KLEIN WANZLEBEN SUGAR BEET, Largely grown for sugar. The root is straight and even. A heavy yielder and very rich in sugar. Oz., 10c; $1 / 4$ lb., $20 \mathrm{c}$; lb., 60c; 5 lbs., $\$ 2.50$, postpaid. Not prepaid, $10 \mathrm{lbs}$. or more at $40 \mathrm{c}$.

"Your products hav'e won for you a very enviable repu. tation. We are very glad to do business with such a firm."

Mammoth Long Red. Paul N. Smith, County Agr. Agent. 


\section{CABBAGE \\ WISCONSIN DISEASE RESISTANT SEED.}

The accompanying photograph of a field at Racine, Wisconsin, shows a test row of cabbage from good commercial seed in the center of a field of disease resistant cabbage.

No clearer demonstration of the value of resistant seed in districts affected by "Yellows" could be giren.

Racine and Kenosha Counties are in the heart of the oldest cabbage section in $\mathrm{W}$ is consin; but a few years back, cabbage growing had been practically abandoned there because the soil had become so badly infected with this destructive fungus, known as 'Yellows.'

Then,

after vears of experiment and study, Dr.

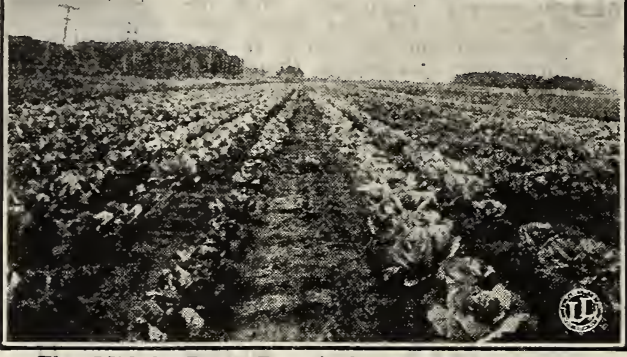

The Middle Row, Practically a Failure, is from Ordinary Seed. All the Other Rows, Each Side, from Disease Resistant Seed.

University of Wisconsin. select. ed three strong heads of the Danish Ballhead or Hollander rariety, which were apparently immune to "Yellows." 'The seed from these were planted and extensive field tests proved the plants from this seed to be as resistant as were the first three.

The disease resistant fea tures have been very carefully maintained and tested out in succeeding crops and the seed we offer can be fully relied upon as genuine "Yellows Resistant", seed. Two other varieties have been added to Hollander so that now we are able to offer Disease Resistant

All our Yellows Resistant Seed is Wisconsin Grown.

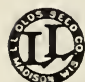

$801 \frac{2}{2} \star$ WISGONSIN HOLLANDER NO. 8 or Wisconsin Danish Ballhead. The same as No. 5 described on the following page, except that it oz., 85c; $1 / 4$ Ib., $\$ 2.75$; Ib., $\$ 9.00$, postpaid.

76. $\star$ WISCONSIN ALL SEASONS. The

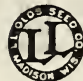
ame as No 80 described below except that it is "Disease Resistant." The supply of authenticated oz., $85 \mathrm{c} ; 1 / 4$ lb., $\$ 2.75 ; 1 \mathrm{~b} ., \$ 9.00$, postpaid.

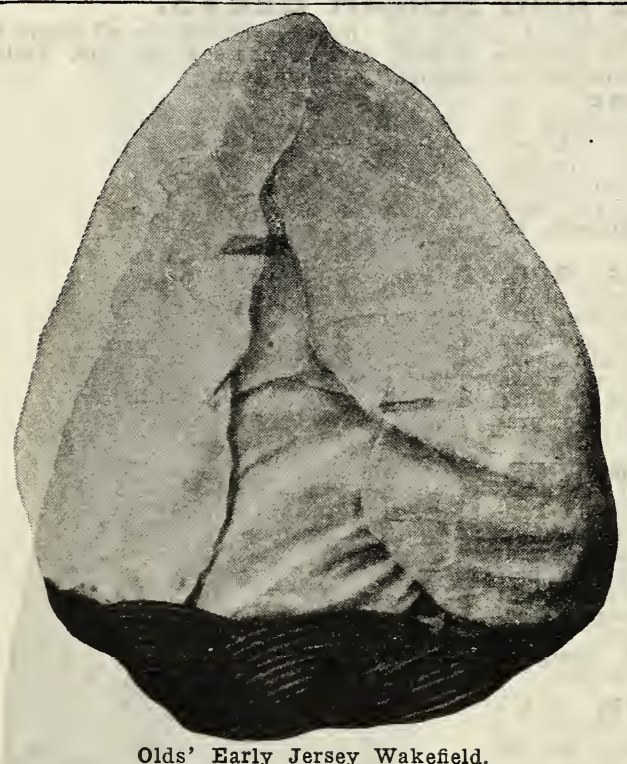

Olds' Early Jersey Wakefield.

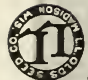
70.

ERSEY WAKE. Wakefield is the best known and most popular extra early cabbage in cultivation. in fact more seed of this rariety is planted in the United States than all others of the same type combined. The head is very solid, comparatively small and running to rather a smail point at the top. Quality is excellent. Pkt., 10c; $1 / 2$ oz., $20 \mathrm{c}$; 0z., 30c; 1/4 lb., 90c; lb., $\$ 3.00$, postpaid.

72. \#CHARLESTON WAKEFIELD. About one week later than Early Jersey Wakefield. The conical heads are broader and larger. Pkt., 5c; $1 / 2$ oz., $15 \mathrm{c}$; oz. $25 \mathrm{c} ; 1 / 4 \mathrm{lb} ., 75 \mathrm{c} ; 1 \mathrm{~b} ., \$ 2.25$, postpaid.

80. . ALL SEASONS. Can be used for either early or late. Heads large, round and deep. A good keeper. The safest for the amateurs, a favorite with -the market gardeners and the most used of any by the kraut manufacturers. Pkt., 10c; $1 / 2$ oz., 20c; oz., $30 \mathrm{c} ; 1 / 4$ lb., $85 \mathrm{c}$; Ib., $\$ 2.75$, postpaid.
(19)

87. MARION MARKET (Wis, Copenhagen Market). This seed comes from the same source as the other two Wisconsin varieties and is a disease resistant strain of Copenhagen Market, which has been named Marion Market. Copenhagen Market needs no introduction. It is already a standard variety and we are sure that our customers will welcome this "Yellows Resistant", seed. Marion Market is good either early or late, has big, round heads, and is a good shipping variety too. Pkt., 20c; $1 / 2$ oz., 70c; $0 \mathrm{z} ., \$ 1.25 ; 1 / 4 \mathrm{lb}$., $\$ 3.75$; lb., $\$ 12.00$.

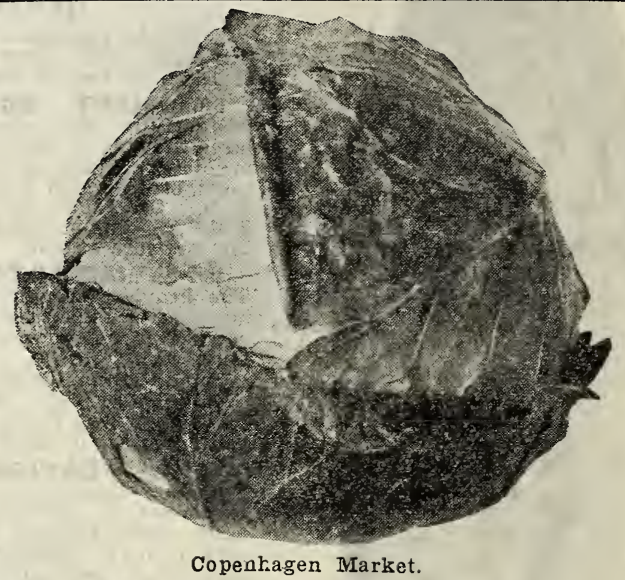

84 $\frac{1}{2}$. \COPENHAGEN MARKET. Undoubtedly the most valuable cabbage of recent introduction, maturing but a few days later than Jersey Wakefield; valuable for both home and market garden. Our seed is the best Danish grown. Pkt., $10 \mathrm{c}$; $1 / 2$ oz., $20 \mathrm{c}$; 0z., $35 \mathrm{c} ; 1 / 4 \mathrm{lb}$., $\$ 1.00 ; 1 \mathrm{~b} ., \$ 3.50$, postpaid.

75. . ALLHEAD EARLY, Earlier than any other large cabbage, larger than any other early cabbage. Heads deep, flat, and solid. If but one variety of cabbage is planted, probably Allhead Early is the best for all purposes. Makes a fine winter cabbage. Pkt., 5c; 1/2 oz., $15 \mathrm{c}$; oz., $25 \mathrm{c}$; 1/4 1b., 75c; 1b., $\$ 2.50$, postpaid.

82 $\frac{1}{2}$. EARLY WINNIGSTADT. Very e a r ly. Heads pointed like the Wakefields. Heads regular, solid and conical; keeps well both summer and winter. Pkt., $5 \mathrm{c} ; 1 / 2$ oz., $15 \mathrm{c}$; Oz., $25 \mathrm{c}$; $1 / 4 \mathrm{lb} ., 75 \mathrm{c} ; 1 \mathrm{~b}$., $\$ 2.25$, postpaid.

831/2. GHINESE OR GELERY GABBAGE. ( $\mathrm{Pe}$ Tsai.) This plant does not form a solid head like cabbage, but grows a long, loose head somewhat like Cos Lettuce. It may be served like lettuce, as cold slaw or like spinach. It is very mild and a real delicacy. One of the best green feeds for chickens. Plant in rows during July and commence feeding when plants are four inches high by pulling out the alternate plants. Continue thinning until plants are about a foot apart when they will make good heads. Pkt., 10c; $1 / 2$ oz., 20c; 0z., 30c; $1 / 4$ lb., $90 \mathrm{c}$; 1b., $\$ 3.00$, postpaid. 


\section{CABBAGE}

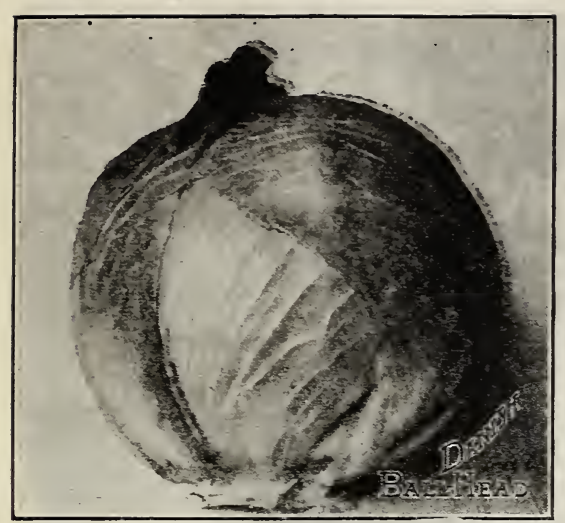

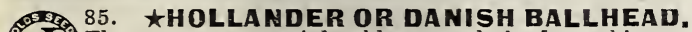
Di: The great commercial cabbage, and the best shipper. qualities. It is the most largely grown variety in America for the winter markets. The heads weigh more for their size than any other variety. They are round as a ball, solid, fine-grained with few outside leares. Thi variety has been bred and perfected for fifty years in Denmark and our seed is produced by one of the best of the Danish growers. Pkt., 10c; 1/2 oz., 20c; oz., 30c; $1 / 4$ lb., $85 \mathrm{c}$; lb., $\$ 2.75$, postpaid.

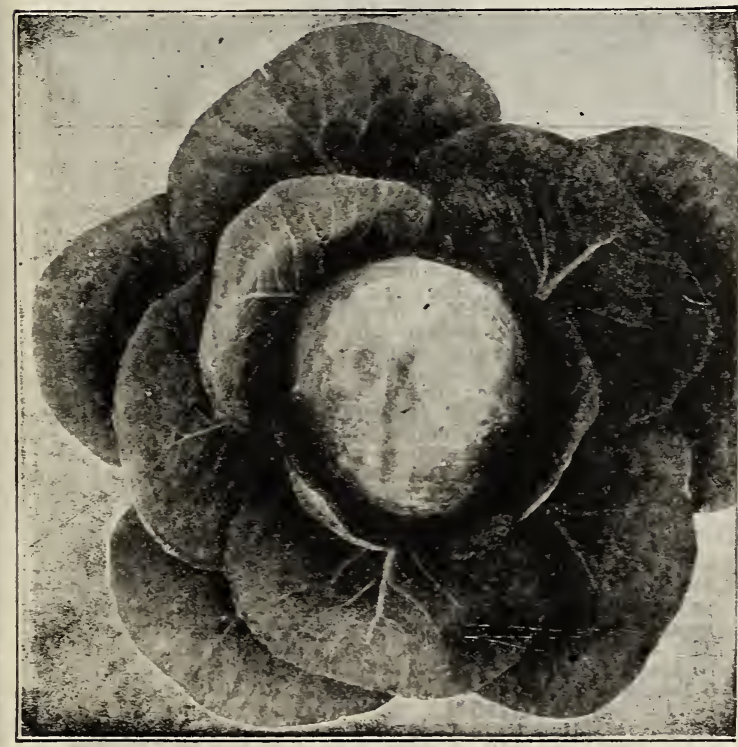

Goidden Acre.

73. + NEW GOLDEN AGRE. Earliest of all round headed rarieties, ITe offered it last rear for the first time. It is an extra early selection of the Copenhagen type, maturing with Jersey Wakefield. Tests covering sereral years indicate that heads nine inches in diameter are produced in 80 days from the time seed is planted. The heads are firm and solid, fully equal to any of the late sorts in that respect. It will stand without bursting in the field for a month or more after maturity. Pkt., $15 \mathrm{c}$; $1 / 2$ oz., 35c; oz., 60c; 1/4 lb., \$1.75; lb., \$5.00, postpaid.

\section{HOME GROWN GABBAGE PLANTS.}

TVe rrow these plants ourselres. Can supply Early Jersey Wakefield, Golden Acre, All Seasons, Marion Market and Wisconsin Hollander No 8. The last three named are from "Disease Resistant" seed. Prices of all: Doz., 25c; 50 for $65 \mathrm{c} ; 100$ for $\$ 1.50$; 500 for $\$ 6.00$, postpaid.
881 2 . \GLORY OF ENKHUIZEN. A very valua. ble introduction from Holland, and an important addition to the list. It is ralued for its earliness, size, keeping qual. ities and flaror. Heads medium, round, handsome with few outer leares. Pkt., 10c; $1 / 2$ oz., 20c; oz., $30 \mathrm{c}$; $1 / 4$ lb., 90c; lb.. \$3.00, postpaid.

83. DRUMHEAD SAVOY. Drumhead Saroy is the best of all the Savoy cabbages. The plant is of strong growth with outer leares growing closely about the firm head. The head grows large and round as a ball, is extremely solid, sweet and tender. Pkt. 10c; 1/2 0z., 20c;

89. MAMMOTH ROCK RED. The best, largest and surest-heading red cabbage; used largely for pickling. Heads are round, solid and of a very attractive deep red color, averaging from ten to twelve pounds in weight. Pkt., 10c; 1/2 0z., 20c; 0z., 30c; 1/4 1b., 90c; 1b., \$3.00, postpaid.

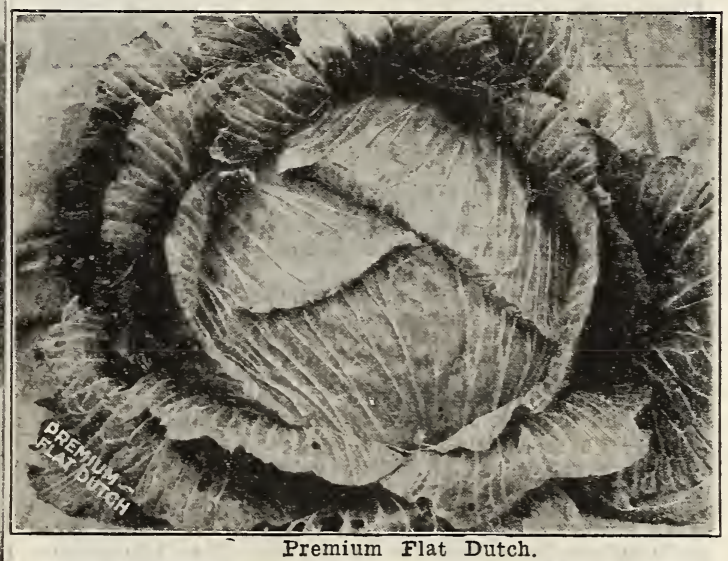

82. ^PREMIUM LATE FLAT DUTCH. The most popular garden rariety and one of our best sellers. 'This old farorite is low growing with large bluish-green heads, round and solid, and broad and flat on top. It is an ex cellent fall and winter rariety, and a good keeper. Plt. $10 \mathrm{c}$; $1 / 2$ 0z., $20 \mathrm{c}$; oz., 30c; $1 / 4$ 1b., $85 \mathrm{c}$; 1b., $\$ 2.75$, postpaid.

\section{FROST PROOF CABBAGE PLANTS}

Grown off the coast of South Carolina where the difficult growing conditions gire the plants great resistance to cold and bad weather. They are guaranteed to stand a temper ature of 20 degrees abore zero. FOU GAIN THREE WEEKS. and make twice as much per acre by haring these early plants. Shipment to you direct from the growing station.

Can supply Early Jersey Wakefield, Charleston Wakefield, Copenhagen Market. Succession and Early Flat Dutch.

Prices: 100 to 400 plants at $50 \mathrm{c}$ per $100 ; 500$ plants, $\$ 1.60 ; 1,000$ or more plants at $\$ 3.00$ per 1,000 , postpaid. By express: 1,000 to 4,000 plants at $\$ 2.00$ per 1,$000 ; 5$, 000 or more plants at $\$ 1.50$ per 1,000

(No orders filled for less than 100 plants of a kind.) 
Our Carrot seed is grown from carefully selected roots. A packet will sow 25 to 30 feet. Three pounds an acre.

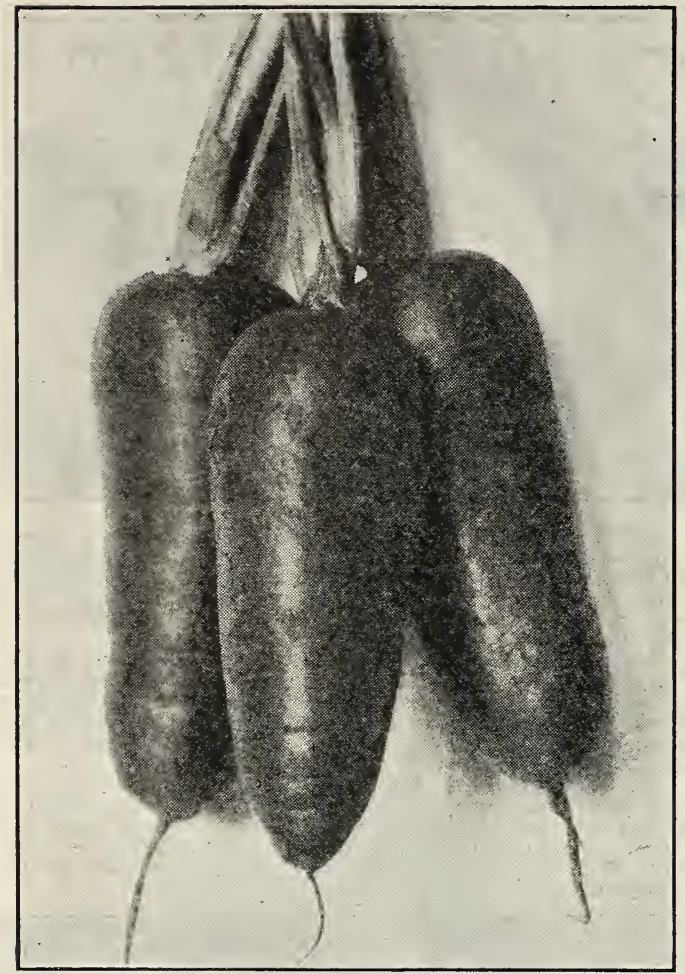

Eurly Chantcray Carrot.

106. „EARLY GHANTENAY. SELECT STRAIN. We pronounce Early Chantenay the best all around carrot in cultivation today. This is the opinion in fact of many market gardeners all over the country. In Texas they are slifting from Oxheart to Chantenay. Our "Select Strain" of this variety comes from C. C. Morse \& Co. and is a decided improvement over the ordinary Chantenay. They describe it as follows:

"One of the most popular varieties used in America, for both table and stock purposes. The true type is ha!f long, thick and very stump rooted, and in dimensions $5 \frac{1}{2}$ inches long, 2 to $2 \frac{1}{2}$ inches thick at the crown and tapering to 1 to $1 \frac{1 / 2}{2}$ inches at the bottom where it is very stump rooted with a decided rat tail. The color is bright orange scarlet and the core is rather large. and definite.

Early Chantenay is not only most desirable for a table and stock carrot but is equally valuable for canning purposes. A Canning Company to whom we furnished our Select Strain of Early Chantenay pronounced it the best of all strains tested for canning type and color and asked us to supply them with the same seed, 50 to 100 pounds, for next year.

We recommend unlhesitatingly our Morse Select Strain of Early Chantenay for anyone who wants a reliable, smooth, uniform, handsome type of carrot that will always give satisfaction for most any purpose. Pkt., 10c; oz., $20 \mathrm{c} ; 1 / 4$ lb., 50c; lb., $\$ 1.50$; 5 lbs., $\$ 6.00$, postpaid.

104. EARLY GHANTENAY. Standard strain of this famous and popular variety. Pkt., 5c; 0z., 15c; 1/4 lb., $40 \mathrm{c}$; 1b., $\$ 1.25$.

105. EARLIEST FRENGH FORGING. The earliest variety; best for forcing; roots almost round, about
$21 / 2$ inches through. Pkt., 10c; oz., $15 \mathrm{c}$; $1 / 4$ lb., $45 \mathrm{c}$; lb., $\$ 1.25$, postpaid.

\section{OLDS' HALF LONG STUMP ROOT.}

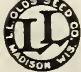

ED. For smoothess lets and small tap root, this carrot is unsurpassed. It is early and one of the best for summer use. Roots 6 to 8 inches long. nearly cylindrical and blunt. Red flesh, sweet and mild. Pkt., 10c; 0z., 15c; 1/4 1b., 45c; lb., $\$ 1.25$; postpaid.

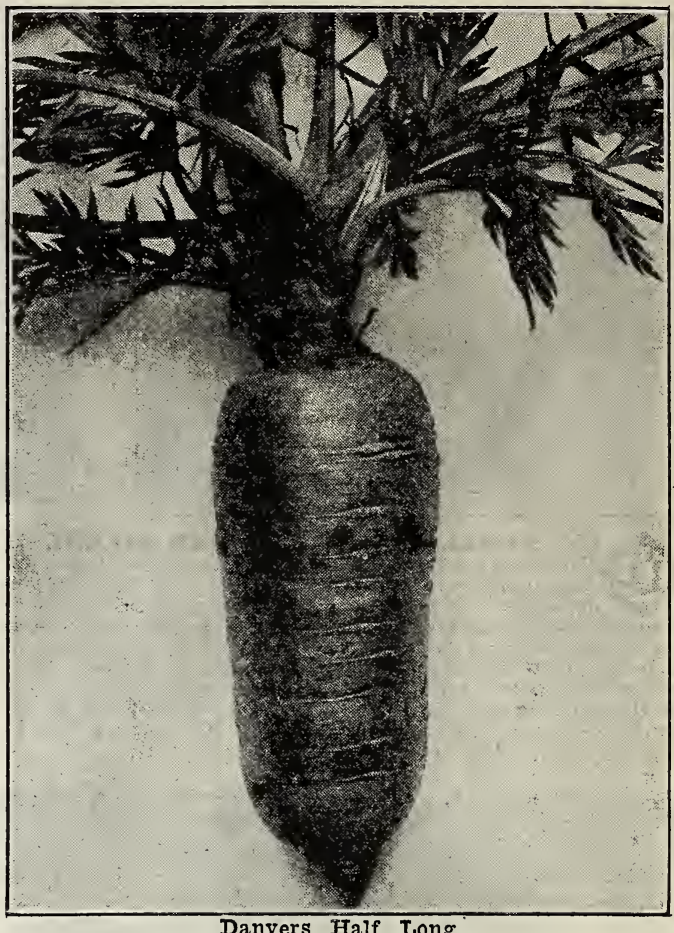

Danvers Half Iong.

100. †DANVERS HALF LONG. A splendid carrot, grown for its productiveness and table quality. One of the best and most desirable for home or market garden. Roots 6 to 8 inches long, tapering uniformly to a blunt point. Flesh deep orange, tender and of excellent quality. A little larger than Chantenay. Immensely popular and deservedly so. Pkt., 10c; oz., 15c; $1 / 4$ lb., 40c; lb., $\$ 1.25$.

103. $\star$ OX $\mathbf{X E A R T . ~ V e r y ~ p o p u l a r ~ a n d ~ p r o n o u n c e d ~ i v ~}$ many "the best all around carrot." Very thick, 5 inches long, nearly as broad, and very blunt at the lower extremities. Equally good for table use or stock. Pkt., 10c; oz., 15c; 1/4 1b., 35c; 1b., $\$ 1.00$, postpaid.

.S. 102. OLD', IMPROVED LONG ORANGE.

- DA well known standard variety; roots long, thick 2. at the crown and tapering regularly to a point: color deep orange; suitable for.both table and field
crop. Pkt., 5c; oz., 10c; 1/4 lb., 30c; lb., 90c, postpaid.

111. LONG ORANGE BELGIAN. While most of our other varieties of carrots also can be profitably grown for stock, Long Orange Belgian on account of its great productiveness and long-keeping qualities will be found a most desirable variety for the farmer to grow for feed. The roots are mammoth in size, yielding often as high as 10 tons per acre. Pkt., $5 \mathrm{c}$; oz., $10 \mathrm{c}$; $1 / 41 \mathrm{~b}$., $25 \mathrm{c}$; $1 \mathrm{lb}$., $85 \mathrm{c}$; 5 lbs., $\$ 3.25$, postpaid. Not prepaid, $10 \mathrm{lbs}$. at $50 \mathrm{c}$.

112. MASTODON. The heaviest cropper of all varieties, yielding more tons to the acre than any other carrot. The roots will average 3 to 4 inches in diameter at the shoulder and a foot or more in length. They are easily pulled in harvesting and do not have to be dug out like most. long-rooted kinds. Creamy white in color, of excellent quality and a wonderfully profitable cheap feed. We earnestly urge farmers to grow more carrots for feed. Cattle like them and they are ideal for horses and sheep. Pkt., 5c; oz., 10c; 1/4 lb., 25c; 1b., 85c; 5 lbs., $\$ 3.25$, postpaid. Not prepaid, $10 \mathrm{lbs}$. or more at $50 \mathrm{c}$.

\section{CHICORY}

1301/. WITLOOF (French Endive.) A delicions winter salad. Grown for its delicate shoots. The roots can be planted in the house during the winter and forced. The leaves can be eaten either raw or cooked. Pkt., 10c; oz., 20c; 1/4 Ib., 60c; lb., $\$ 1.80$, postpaid.

\section{GRESS}

134." EXTRA CURLED. (Pepper Grass.) The best variety. Every one should sow a little for early spring use. Pkt., 10c; oz., 15c; 1/4 1b., 40c; lb., \$1.25. 


\section{CELERY}

CULTURE. Since celery seed is slow to germinate, ample time must be given. Sow thinly in hot-bed or cold-frame; cover lightly. As soon as the plants are about three inches high, clip the tops or transplant to make stocky plants. When about 8 inches high set about 6 inches apart in rows about 3 or 4 feet apart. Never hoe or work about celery when covered with dew or when the weather is moist, or rust will result. For winter use bank the plants where they stand, in the fall, without litting.

Each packet contains enough seed to produce 1,000 plants; one ounce will produce 7,500 plants; one fourth pound enough for an acre.

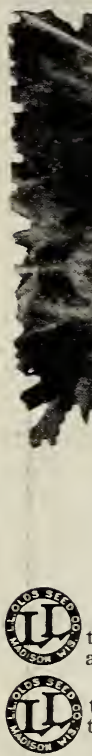

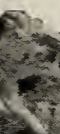

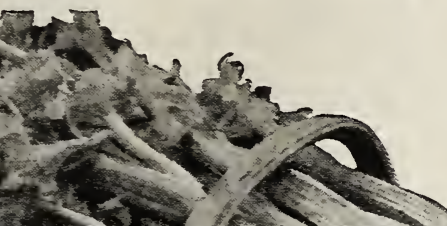

Ses

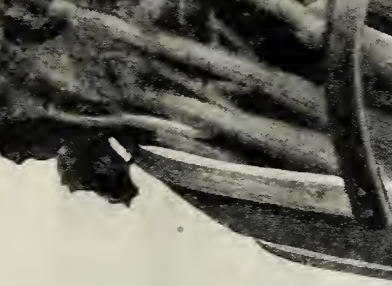

117. „GOLDEN SELF-BLANGHING. (American He mportance to celerr growers. Plants, stocky and robust and of compact habit; stalks, hears and solid, with large, stringless, close-set ribs; heart a fine golden yellow and remarkably crisp and tender.

Golden Self-Blanching is the earliest to mature, not liable to blight and a good keeper and shipper. The best known, most grown, most wanted celery on the market today, and by far our biggest seller. Pkt., 10c; oz., 50c; lb., $\$ 1.75$; Ib., $\$ 6.00$, postpaid. 118. GIANT PASGAL. standard fall and winter rariets, but not a good shipper on account of its tender stalks. This fact, howerer, recommends it as a homegarden or home-market rariety. Pkt. 10c; 0z., 30c; $1 / 4$ lb., $85 \mathrm{c}$; lb., $\$ 2.75$, postpaid.

\section{HOME GROWN CELERY} PLANTS.

Te can furnish Golden Self Blanching (early) and Winter Queen (late). Ready about June 15th. Doz., 25c; 100 for $\$ 1.50$; 500 for $\$ 5.50$, postpaid.

121. WINTER QUEEN. One of the best and most dependable winter rarieties; of medium height; broad, light green stalks, very solid and crisp. Pkt., 5c; 0z., 25c; 1/4 1 b., 75c; lb., \$2.25, postpaid.

125. CELERIAC, NEW GIANT PRAGUE, An casily grown regetable that deserres a place in your garden. It forms a turnip-shaped root about 2 inches in diameter, with the flavor of fine celery. Splendid for soup, stews, salads, etc. Pkt., $10 \mathrm{c}$; oz., $30 \mathrm{c} ; 1 / 4 \mathrm{lb} ., 90 \mathrm{c}$; lb., \$2.75, postpaid.

\section{CAULIFLOWER}

90. \IMPROVED EARLY SNOWBALL. Un doubtedly the earliest and most popular variety either for the home or market garden. The medium sized, snow. white heads ( $s i x$ to ten inches in diameter) are firm, compact and solid, with few short, upright leares. Our seed comes from one of the best Danish growers and is equal to any strain of Snowball on the market. Pkt., 20c; $1 / \pm$ oz. $75 \mathrm{c} ;$ oz., $\$ 2.25 ; 1 / 1$ 1b., $\$ 7.50$, postpaid.

93. †DRY WEATHER. The best all-purpose cauliflower for every kind of soil. It produces large, solid, pure white heads. Matures about a week later than Im. proved Early Snowball. Adapted to dry locations.

20c; $1 / 4$ 0z., 75c; Oz', EARLIEST OF ALL. The earliD. 1 est and quickest growing cauliflower we know of. $20 \mathrm{c} ; 1 / 4$ oz., $75 \mathrm{c} ;$ oz., $\$ 2.25 ; 1 / 4$ lb., $\$ 7.50$, postpaid. 94. AUTUMN GIANT. One of the finest late rarieties. Heads large and compact. A rigorous grower. Pkt., 10c; $1 / 4$ oz., $20 \mathrm{c}$; 0z., $50 \mathrm{c}$; $1 / 4$ lb., $\$ 1.50$, postpaid.

HOME GROWN CAULIFLOWER PLANTS.

TWe can furnish Improved Early Snowball (ear Dry Weather (late). Ready early in Mar. Doz., 40c; 50 for $\$ 1.25 ; 100$ for $\$ 2.25$, postpaid.

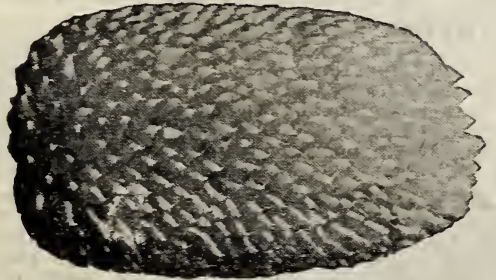

Tom Thumb or Japanese Hulless. $\$ 1.25$, postpaid.

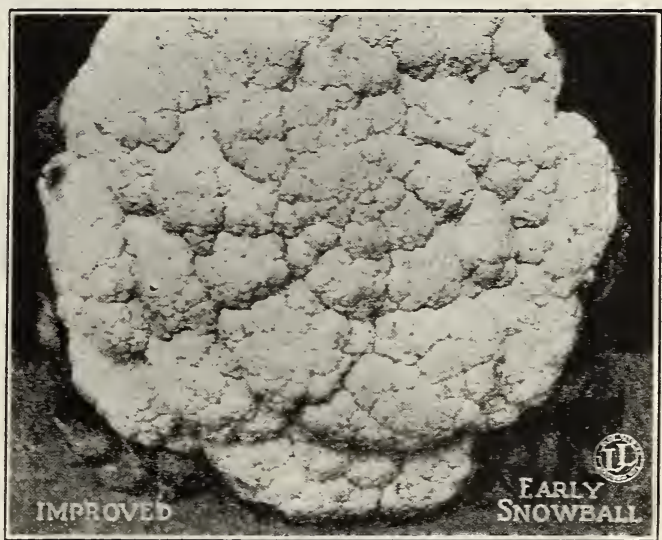

POP CORN

150. WHITE RICE. The familiar shoepegged rariety, sereral good sized ears to each stalk. Pkt., 5c; Ib., 30c; 2 lbs., $50 c$; 5 lbs., \$1.10, postpaid. Not prepaid, 10 lbs. or over, at $12 \mathrm{c}$.

151. OLDS' BLUE BEAUTY. Medium sized ear, almost blue, rerF productive and a good popper. Pkt., 10c; Ib., 35c; 2 1bs., 60c; 5 lbs.,

$151 \frac{12}{2}$. TOM THUMB OR JAPANESE HULLESS. A dwarf $\mathrm{va}$. riety with short stubby ears and long pointed sharp kernels, almost hulless. Pops without the hard center. The most popular and best known ra. riets. Pkt., 10c; 1b., 40c; 2 Ibs., $70 \mathrm{c} ; 5$ lbs., $\$ 1.35$, postpaid.

151. QUEEN'S GOLDEN. Long jellow ears with flat round kernels. Ears produced in abundance and easy to husk. Pkt., 5c; lb., 30c; 2 lbs. $50 \mathrm{c} ; 5$ lbs., $\$ 1.00$, postpaid. 
Our Sweet Corn is all first class, high testing seed. Our packets each contain two ounces, larger than the usual packet and enough for 30 to 40 hills. One peck (11 lbs.) will plant an acre. We recommend using Semesan Jr., with Sweet Corn as well as Field Corn. See page 9.

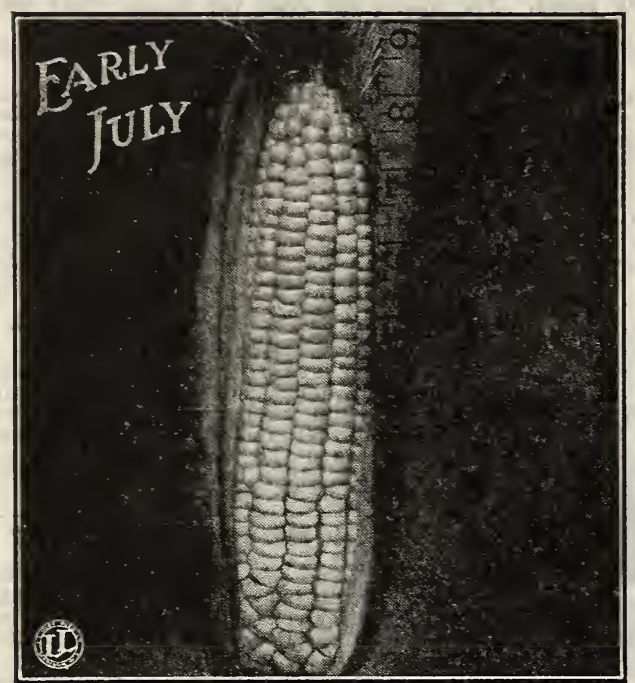

(3) 1351/2. †EARLY JULY. Way ahead of everyD thing else in earliness. For seven years we have been growing this variety and we like it now bet-
ter than ever. To say that it is earlier than Golden Bantam is perhaps recommendation enough. It has produced corn ready for table use in 60 days every year for seren consecutive years.

The ears are creamy white, about seven inches long and on account of the very admirable habit of producing two, three and even four good ears to the stalk it is really very productive. It has a short stalk with few leaves, so you can plant six or eight kernels to the hill. Large pkt. (2 ozs.), 10c: 1/2 1b., 25c; 1b., $40 \mathrm{c} ; 2$ lbs., $70 \mathrm{c}$; 5 lbs., $\$ 1.40$, postpaid. ${ }^{2}$ Not prepaid, $10 \mathrm{lbs}$. or more at $22 \mathrm{c}$.

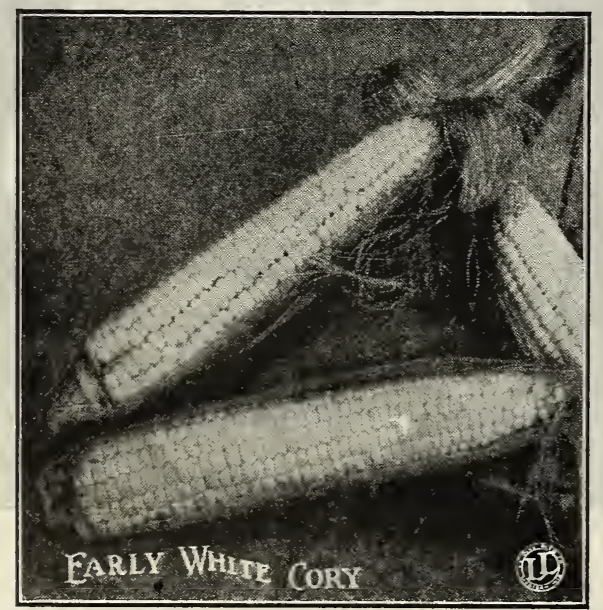

136. MAMMOTH WHITE CORY. Larger than the original White Cory and still one of the very earliest varieties of sweet corn. The ears are longer than most varieties of its class, and with from two to four more rows of kernels to the cob. It was named Mammoth White Cory because the ears are so large for an extra early variety. Large pkt. (2 ozs.), $5 \mathrm{c}$; $1 / 2$ 1b., $15 \mathrm{c}$; 1b., $25 \mathrm{c} ; 2$ lbs., $45 \mathrm{c}$, postpaid. Not prepaid, $10 \mathrm{lbs}$. or more at $16 \mathrm{c}$.

1401/2. BLACK MEXICAN. Everyone who has eaten this delicious variety remembers it as one of the richest and sweetest of all varieties of sweet corn. Large pkt. (2 ozs.), 5c; $1 / 2$ 1b., $15 \mathrm{c}$; 1b., $25 \mathrm{c} ; 2$ lbs., $45 \mathrm{c}$, postpaid. Not prepaid, 10 lbs. or more at $16 \mathrm{c}$.
142. $\star$ GOLDEN BANTAM. Most popular variety in the United States. Everyone likes Golden Bantam. Indeed, many people will not take any other when it is obtainable. The flavor is deliciously distinct. superior to that of any other corn. The small 8-rowed ears, usually less than 6 inches in length and several on a stalk, are perhaps higher in sugar content than any other corn. It is only 10 to 12 days later than Early July, making a good succession when both varieties are planted at the same time.

The kernels are tender, very wide and of good depth, while the cob is small, and the flavor delicious. To have corn at its best, raise it in your own garden. Large pkt. (2 oz.), 10c; 1/2 lb., 20c; 1b., 35c; 2 lbs., $60 \mathrm{c} ; 5 \mathrm{lbs}$., $\$ 1.20$, postpaid. Not prepaid, $10 \mathrm{lbs}$. or more at $17 \mathrm{c}$.

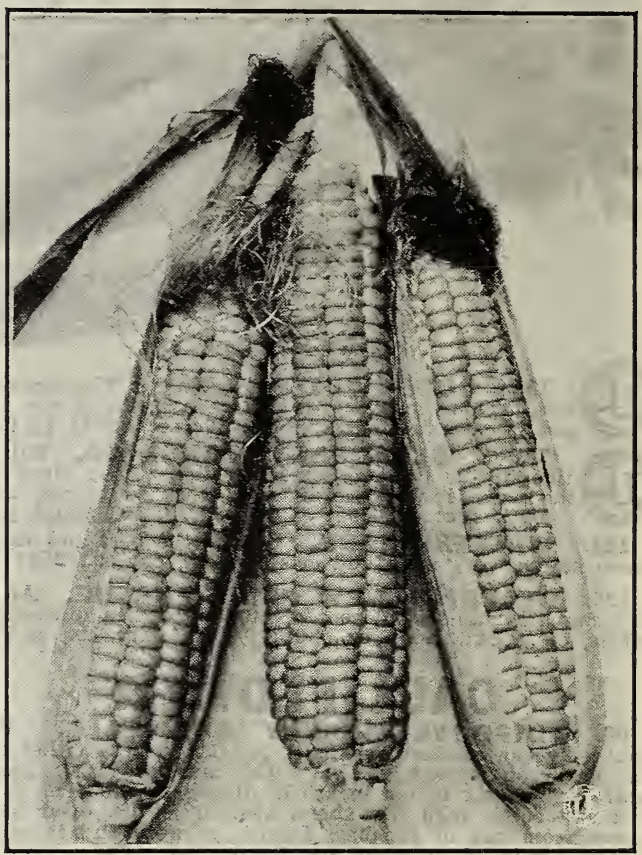

Golden Bantam.

1421/2. BANTAM EVERGREEN. Many attempts have been made to combine the sweetness, earliness, color and flavor of Golden Bantam, with the tender skin and large ear of the Evergreen. The Bantam Erergreen is the only really successful cross. It has retained many of the excellent qualities of both parents, being more productire than Golden Bantam and much earlier than Evergreen. Large pkt. (2 ozs.), 10c; 1/2 lb., 20c; 1b., 35c; 2 lbs., $60 \mathrm{c}$, postpaid. Not prepaid, $10 \mathrm{lbs}$, or more at $20 \mathrm{c}$.

GSe 144. WONDER BANTAM. One of the sweetest I first earlies. It is a new extra early variety with 2. rather large ears, six to eight inches in length. The tinged with red when ripe, but pure white in the eating stage. The yield is heavy and at the same time it matures early. Large pkt. (2 ozs.), 10c; $1 / 2$ lb. 25c; 1b., $40 \mathrm{c} ; 2$ lbs., $70 \mathrm{c}$, postpaid. Not prepaid, $10 \mathrm{lbs}$. or more at $22 \mathrm{c}$. 5. 145 . ‘OLDS' EARLY, EVERGREEN. An TD extra fine strain of Stowell's Evergreen with large ears, yet ready for the table 7 to 8 days earlier than Stowell's. It retains the fine sugary flavor and tenderness of kernel that have made the Evergreens popular. Large pkt. (2 ozs.), 10c; $1 / 2$ lb., $20 \mathrm{c}$; 1b., $35 \mathrm{c}$; $2 \mathrm{lbs}$., $60 \mathrm{c} ; 5 \mathrm{lbs}$., $\$ 1.25$, postpaid. Not prepaid, $10 \mathrm{lbs}$. or more at $20 \mathrm{c}$.

1411/2. GOLDEN GREAM. A late yellow. A cross of Golden Bantam and Country Gentleman. The result is a yellow Country Gentleman with all the excellent table qualities of the two best varieties for eating. Large plat. ( 2 ozs.), 10c; 1/2 lb., 20c; Ib., 30c; 2 lbs., 55c, postpaid. Not prepaid, $10 \mathrm{lbs}$. or more at $18 \mathrm{c}$. 


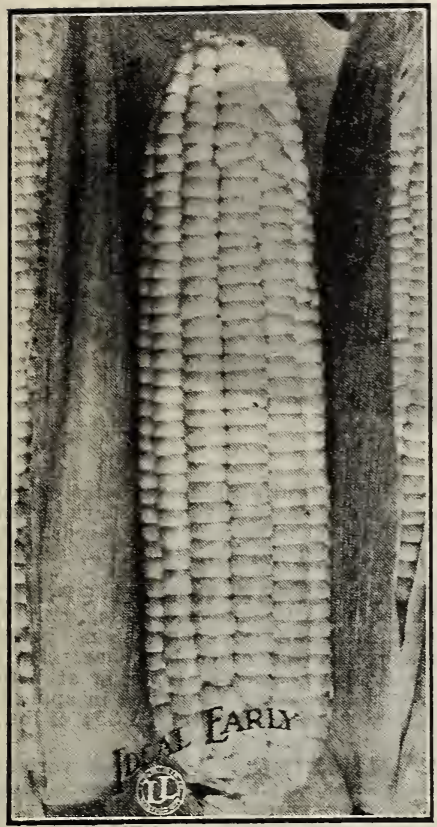

Olds' Ideal Early.
Use Semesan Jr. on your seed Sweet Corn before planting. See page 9. Ask for special booklet.

139. *EA R L Y champion. We offer this as the best main crop, second-early sweet corn. Stalks large and
leafy; and dependable. The ears are large and there are usually two on a stalk. Kernels are large and white and full of milk; 10 to 12 rows to the ear, tender an d sweet.

An all-round good sweet corn for either home or market garden. Popular because of its g re a t productireness. Our largest selling second early. Large pist. (2 ozs.), 10c; $1 / 2$ lb., $20 \mathrm{c} ; 1 \mathrm{~b}, 35 \mathrm{c} ; 2$ 1bs., $60 \mathrm{c} ; 5 \mathrm{lbs}$., $\$ 1.20$, postpaid. Not prepaid, 10 Ib.

Use 2-12-2 Fertilizer for Sweet Corn. Vigoro is also fine. See page 92. It pays big to use fertilizer.

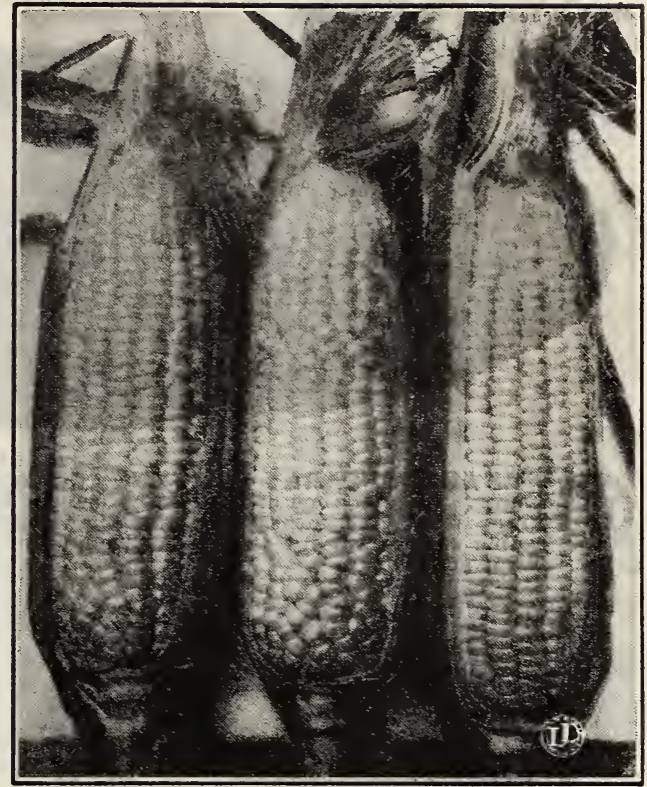

Early Champion.

137. OLDS' IDEAL EARLY. A highly bred second early. We are offering here one of the finest and D. largest-eared of the early varieties of sweet corn on the market today. The Ideal Early withstands drought remarkably well, adapts itself to any kind of soil, producing ears almost as large as those of Stowell's Ever-
green. It is exceptionally prolific. Large pkt. (2 ozs.), 10c; 1/2 1b., 25c; lb., 40c; 2 1bs., 70c; 5 lbs., $\$ 1.40$, postpaid. Not prepaid, $10 \mathrm{lbs}$. or more at $20 \mathrm{c}$ per $\mathrm{lb}$.

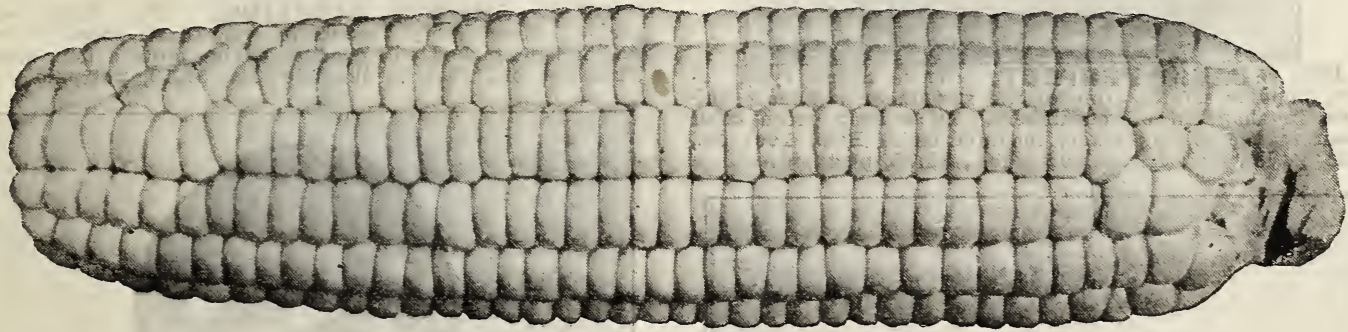

147. \STOWELL'S EVERGREEN. The best ell's Evergreen has proven its worth over and over again, during a period of many years. It makes the largest ear and the most fodder of any sweet corn we list, and the corn is tender, sweet, and of excellent flavor. Its popularity is also due to the fact that it remains long in the milk before ripening up, thereby lengthening its season for table use; hence the name, Evergreen. Iarge pkt. (2 ozs.), 10c; 1/2 lb., 20c; 1b., 35c; 2 lbs., 60c; 5 lbs., \$1.25, postpaid. Not prepaid, $10 \mathrm{lbs}$. or more at $18 \mathrm{c}$ per $\mathrm{lb}$. EVERGREEN SWEET FODDER. See page 13.

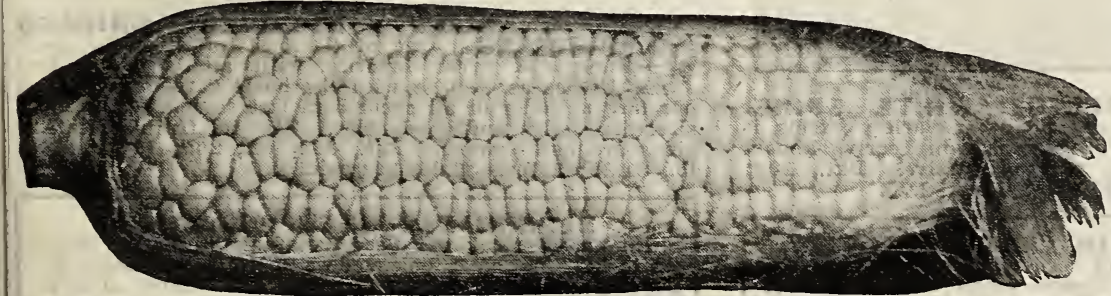

Howling Mob.
$1391 / 2$. „COUNTRY GENTLEMAN. Often called "Shoe-peg" corn beeause of the long, narrow, pointed kernels, with their crowded and irregular arrangement on the cob. It is a distinct late variety, with 2 to 5 big ears on a large stalk. A favorite main crop sweet corn, packed from tip to butt with long pearly-white kernels set closely on a remarkably small cob. It is sweeter and finer fla best of the late varieties for table use. Large pht. (2 ozs.), $10 \mathrm{c} ; 1 / 2 \mathrm{lb} ., 20 \mathrm{c} ; 1 \mathrm{~b}$., $35 \mathrm{c} ; 2$ lbs., $60 \mathrm{c} ; 5 \mathrm{lbs}$., $\$ 1.30$, postpaid. Not prepaid, $10 \mathrm{lbs}$, or more at $20 \mathrm{c}$ per $1 \mathrm{~b}$.

$138 \frac{1}{2}$. \HOWLING MOB. This variety is so valuable that it heads the list with many eastern growers. When it was first offered the demand for it became so loud and clamorous that it was given its queer but appropriate name. It is one of the best flarored and most tender of all second-early or main crop rarieties. Large pkt. (2 ozs.), $10 \mathrm{c} ; 1 / 2 \mathrm{lb} ., 20 \mathrm{c}$; 1b., $35 \mathrm{c} ; 2$ lbs., $60 \mathrm{c}$, postpaid. Not prepaid, 10 Ibs. at $20 \mathrm{c}$. 


\section{CUCUMBER}

A packet will plant from 12 to 15 hills. Two pounds will plant an acre. Try the new "Evergreen" for cu. cumber beetles. See page 93.

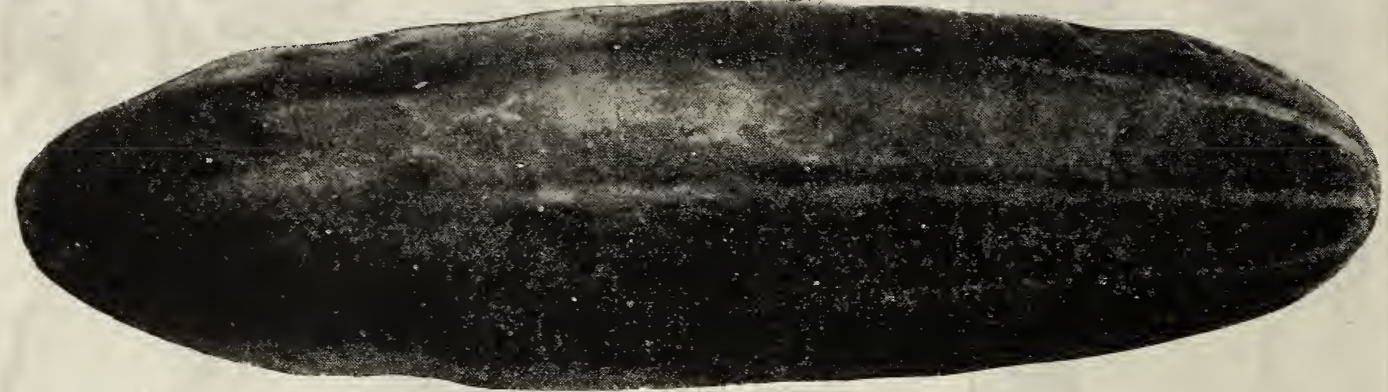

Olds' Early Fortune.

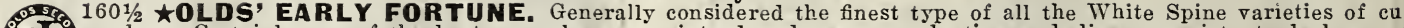

T. cumber Certainly one of the best cucumbers ever introduced; very productive and disease resistant, dark green skin; fruits nine inches long, slightly tapering; flesh white, very firm and crisp, with rery few seeds. A leading market variety and also splendid for the home garden. Pkt., 10c; oz., 20c; 1/4 lb., 40c; lb., \$1.25; 2 lbs., $\$ 2.25$, postpaid.

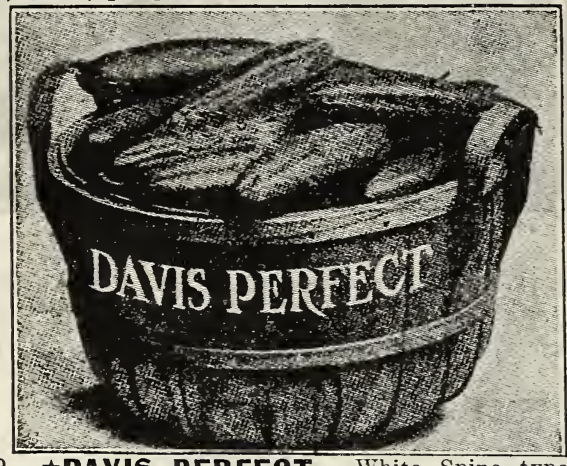

169. very popular strain, One of the smoothest and most uniform in shape of all cucumbers. Of a deep green color when in the slicing stage, medium late. Pkt., 10c; oz., $25 \mathrm{c}$; $1 / 4$ lb., $50 \mathrm{c}$; 1b., $\$ 1.50 ; 2$ lbs., $\$ 2.75$, postpaid.

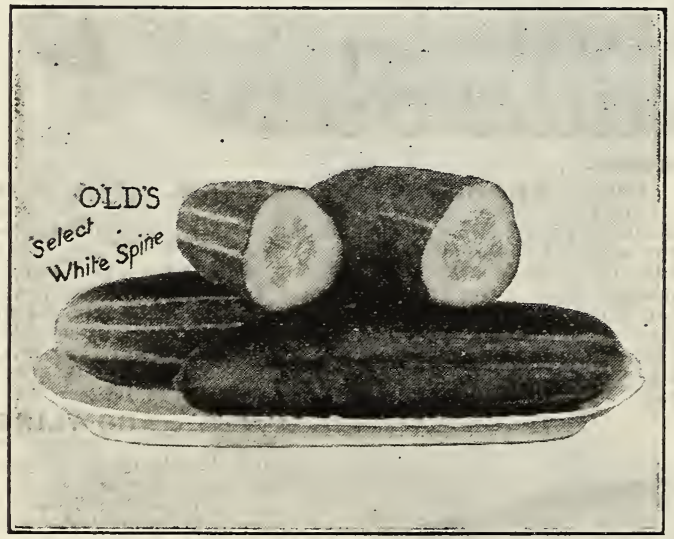

164. OLDS' SELECT WHITE SPINE. - Our best White Spine; no other variety excels it 2. in quality. A very select strain, early, almost cylindrical in shape, very productive. Plkt., 10c; oz., $20 \mathrm{c} ; 1 / 4 \mathrm{lb}$., $50 \mathrm{c}$; 1b., $\$ 1.50 ; 2$ lbs., \$2.75.

\section{SPEGIAL PRIGES IN LARGE QUANTITY}

If needing quite a lot of seeds send us your list for special prices. We are always ready to try to meet quotations made by any other reliable house.
01591/2, OLDS' EARLIEST WHITE SPINE T Our earliest White Spine Cucumber. It is, in fact, probably the earliest of all large cucumbers, being ten days ahead of the other big ones. It is uniform in size and shape, smooth, tapering at both ends and of a deep green color. Verv handsome in appearance. Pkt., 10c; oz., 25c; 1/4 1b., 45c; lb., \$1.35; 2 lbs., $\$ 2.50$, postpaid.

170. JAPANESE GLIMBING. A distinct variety used to cover trellises, fences, etc. When in the slicing stage color is a splendid deep green. A rery hardy, vigorous-growing cucumber of good quality. Length 9 inches. Pkt., 10c; 0z., 20c; 1/4 lb., 45c; lb., \$1.35, postpaid.

156. EARLY GREEN GLUSTER. A small variety, about 6 inches in length, produced in clusters. Very early, prolific and uniform. Skin smooth, the ends tapering slightly. Very popular as an early pickling cucumber. Pkt., 5c; 0z., 15c; $1 / 4$ lb., 35c; lb., \$1.00, postpaid.

1571/2. SNOW'S PICKLING The ideal bottle pickle. Enormously productive, very dark green in color and if kept picked will produce during quite a long season. Pkt., 5c; oz., 15c; $1 / 4$ lb., 35c; 1b., $\$ 1.10$, postpaid.

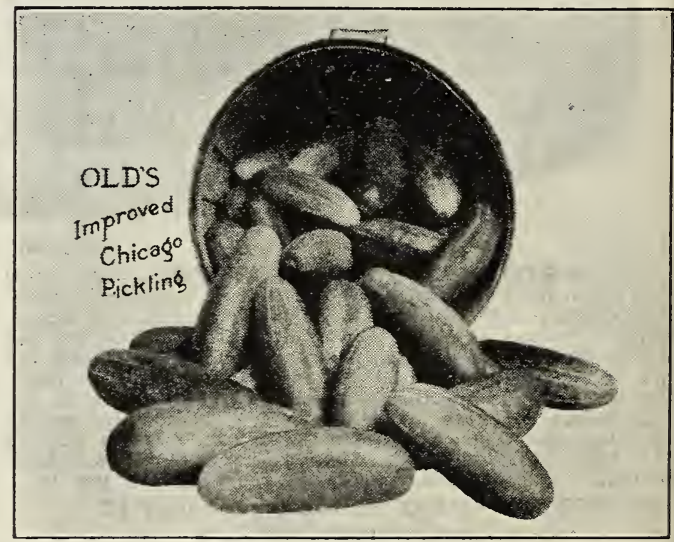

\section{8. †OLDS' IMPROVED GHIGAGO}

PICKLING. One of the best varieties for pick. U. ling. A great favorite with all large pickling houses as well as with the home gardener. It was our largest seller of all cucumbers last season. Of uniform size, productive and good color. Sets its fruits when the vines are quite young. Pkt., 10c; 0z., 20c; $1 / 41 \mathrm{lb} ., 40 \mathrm{c}$; lb., $\$ 1.25 ; 2$ lbs., $\$ 2.25$, postpaid.

\section{DEPENDABLE SEED POTATOES}

Do not overlook our Seed Potatoes offered on pages 24 to 27 . We have long made a specialty of choice dependable stock of the leading varieties. Most of it is "Certified Stock." 


\section{CUCUMBER}

\section{8. \EARLY}

Rumber in cultiration. This ra riety can be picked early for bottle cucumbers or allowed to grow just a few days longer for first early slicers. It is very even, smooth, tender, crisp and is

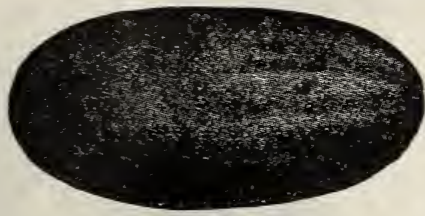

Early Russian. hardy and free from disease. Pkt., 10c; 0z., 20c; 1/4 1b., $45 \mathrm{c}$; lb., $\$ 1.35$, postpaid.

$162 \frac{1}{2}$. KLONDIKE. Another White Spine rariety, excellent for shipping. Medium early, dark green, about 7 inches long. The fruits are thick at the stem end, rery attractive in appearance, retaining color and crispness a long time. A wonderful keeper. Pkt., $5 \mathrm{c}$; oz., $15 \mathrm{c} ; 1 / 41 \mathrm{~b}$., $35 \mathrm{c}$; 1b., $\$ 1.00 ; 2$ lbs., $\$ 1.80$, postpaid.

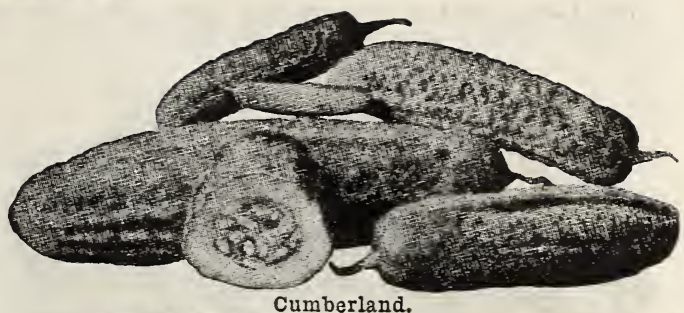

163. $\star$ CUMBERLAND. One of the best all purpose cucumbers with only a seeds and a small seed cavity. A rapid grower. The fruit is straight and of good form, firm and crisp. An excellent early slicer. Pkt., 10c; oz. 20c; $1 / \frac{1}{4} 1 \mathrm{~b} ., 40 \mathrm{c} ; 1 \mathrm{~b} ., \$ 1.25 ; 2$ 1bs., $\$ 2.25$, postpaid.

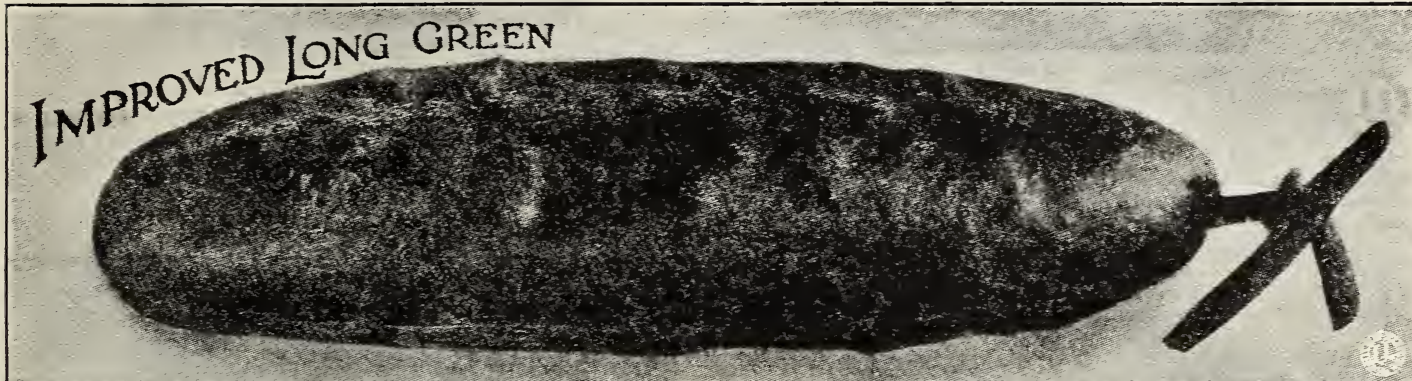

acellent pickles, and when ripe is the best for sweet pickles. Vines rigorous and productive. Fruits long, firm
and crisp. Color deep green, flesh white and firm. Ver $y$ good for slicing. The seed we offer is an improved strain. Pkt., 10c; 0z., 25c; 1/4 1b., 50c; 1b., $\$ 1.50 ; 2$ lbs., $\$ 2.75$, postpaid.

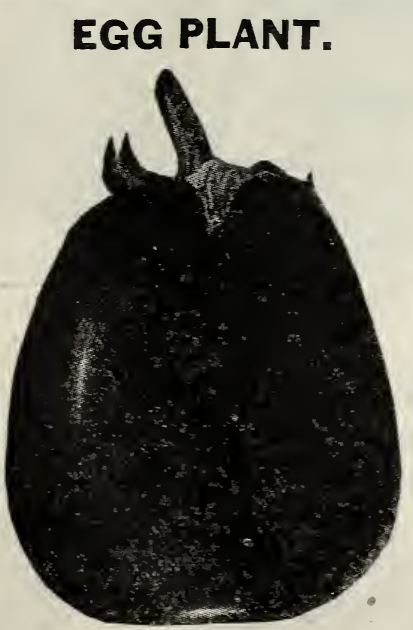

Black Beauty.

181. †BLACK BEAUTY. The best early market $\nabla a$. riety. Also the best for home use. It is fully ten days earlier than the New York Improred Purple and nearly as large. Spineless. Pkt., 10c; 0z., 50c; 1/4 lb., $\$ 1.50$; lb., $\$ 5.00$, postpaid.

180. NEW YORK IMPROVED PURPLE. The farorite market rariety. Plant is spineless, large and spreading, with light green foliage and producing 4 to 6 large oral fruits. Dark purple in color. Pkt., 10c; oz., $40 \mathrm{c} ; 1 / 4$ lb., $\$ 1.40$; lb., $\$ 4.50$, postpaid.

\section{OKRA.}

278. WHITE VELVET. Tery productire and superior in flaror to any other variety. Pkt., 10c; 0z., 15c; $1 / 4$ lb., $25 \mathrm{c}$ : 1b.. $75 \mathrm{c}$, postpaid.

HORSE RADISH ROOTS. 12 for 25c; 100 for $\$ 1.25$, postpaid.

\section{ENDIVE.}

185. GREEN CURLED. Dark green leaves; blanches white. WHITE CURLED. Leaves finely cut and almost white.

187. BROAD-IEAVED BATAVIAN. Leares very broad. All varieties. Pkt., 10c; 0z., 15c; $1 / 4$ 1b., 40c; $1 \mathrm{~b} ., \$ 1.25$.

\section{GOURDS.}

199. MIXED GOURDS. This mixture contains a very wide range of colors, shapes, and sizes, Pkt., 10c; oz., $20 \mathrm{c} ; 1 / 4$ lb., 50c; lb., $\$ 1.75$, postpaid.

193. HERCULES CLUB. Edible, ornamental, and useful. Pkt., 10c; 0z., 20c; $1 / 1 / 1 \mathrm{~b} . .60 \mathrm{c} ; 1 \mathrm{~b} ., \$ 2.00$, postpaid.

\section{HERBS}

480. ANISE. For flaroring. Pkt., 10c; oz., 20c, postpaid.

483. CARAWAY. Seed used in rye bread, cookies and cakes. Pkt., 10c; oz., 15c, postpaid.

485. DIIL. Leaves and seed used in dill pickles, soups and sauces. Pkt., 10c; 0z., 15c; 1/4 1b., 40c, postpaià.

489. MARJORAM. Sweet. Tops green or dried, used for flaroring soups. Pkt., 10c; oz., $35 \mathrm{c}$, postpaid.

492. SAGE. (Perennial.) Dried leares much used for seasoning in dressings: the most popular of all herbs. Pkt., 10c; oz., 50c, postpaid.

196. THYME. Used for tea. Pkt., 10c; 0z., 50c, postpaid. MIXED HERBS. A mixture of all varieties. Pkt., 10c; oz., 20c, postpaid.

\section{KALE.}

201. DWARF CURLED SCÖTCH. Dwarf špreading variety. Attractive bright green color. Vers hardy. Pkt., 10c; 0z., 15c; 1/4 1b., 35c; 1b., \$1.00, postpaid.

\section{KOHL RABI.}

205. EARIY WHITE VIENNA. Probably the best early variety. Extremely early with small tops. Medium size bulbs. Pkt., 10c; 0z., 25c; 1/4 1b., 70c; 1b., \$2.25, postpaid.

206. PURPLE VIENNA. A popular rariety for table use. Pkt., 10c; 0z., 20c; $1 / 41 \mathrm{~b} ., 65 \mathrm{c} ; 1 \mathrm{~b} ., \$ 2.00$, postpaid.

\section{LEEK.}

210. AMERICAN FLAG. Large, thick stems. Pkt. $10 \mathrm{c} ; 0 \mathrm{z} ., 25 \mathrm{c} ; 1 / 4$ 1b., $75 \mathrm{c}$; 1b., $\$ 2.25$, postpaid.

\section{MUSTARD.}

257. SOUTHERN GIANT CURLED. Best and most popular variety. Pkt., 10c; oz., 15c; 1/4 1b., 25c; 1b., 75c, postpaid. 


\section{LETTUCE}

Our Lettuce seed is grown by the most careful seed growers in California. Each packet will sow 25 to 30 feet of drill. Three pounds will seed an acre.

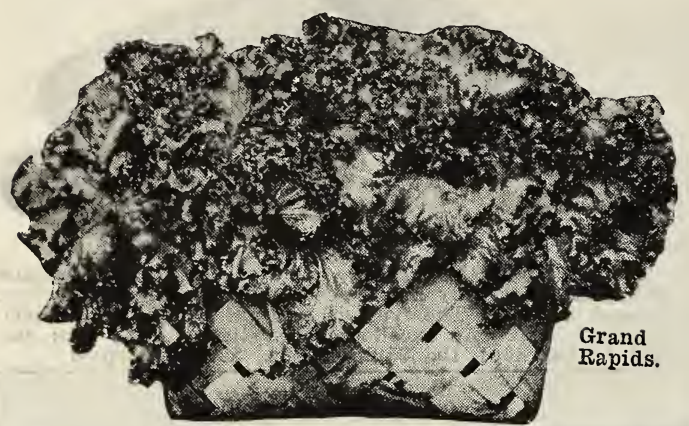

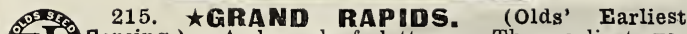
(1) Eorcing.) A loose-leaf lettuce. The earliest valight green leaves much crumpled curled and frilled. It is of good quality, very brittle and a handsome lettuce for garnishing. Well known and a favorite everywhere. Pkt., 10c; 0z., 20c; 1/4 lb., 50c; lb., \$1.50, postpaid.

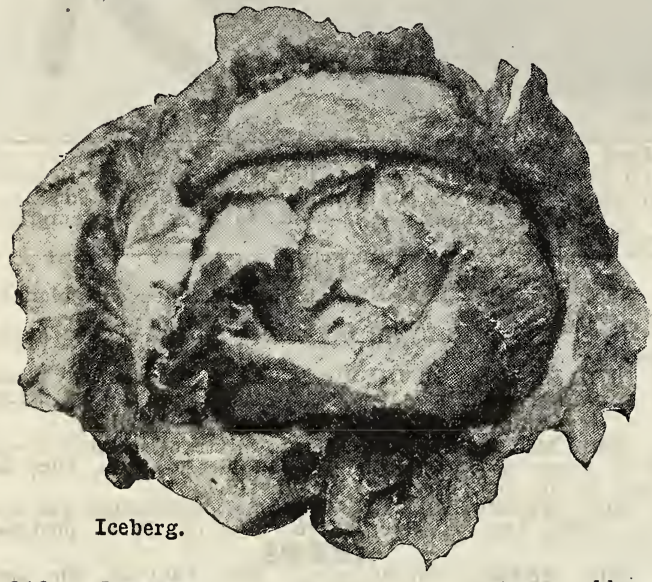

216. IGEBERG A large, medium late, cabbageheading lettuce. Curled and crisp; leaves wavy with fringed edges. It retains its brittleness even in hot weather. Pkt., 10c; 0z., 20c; 1/4 lb., 60c; lb., \$1.75, postpaid.

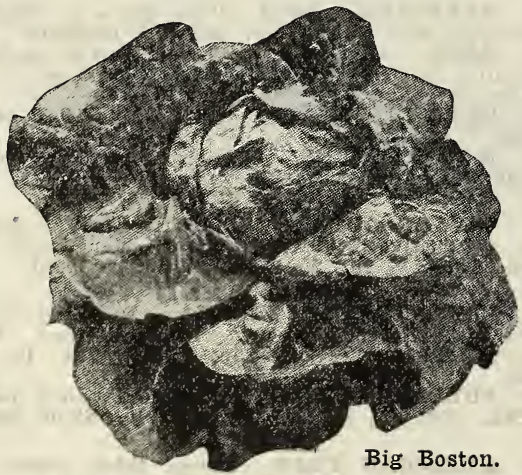

222. $\star$ BIG BOSTON. A head lettuce. One of the most largely grown varieties in cultivation; early, hardy, with brittle head tending to a golden yellow. Pkt., 5c; oz., $15 \mathrm{c}$; $1 / 4$ lb., $45 \mathrm{c}$; lb., $\$ 1.25$, postpaid.

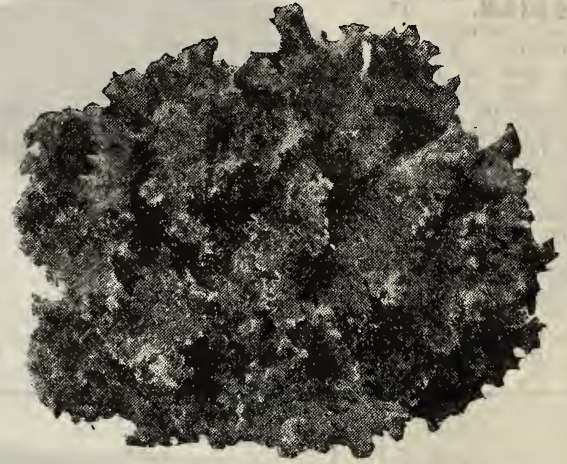

Black-Seeded Simpson

219. OLDS' BLACK-SEEDED SIMPSON. F Probably the most widely planted loose-leaf variety. The leaves, pale green in color, are much curled and twisted, very brittle, crisp and sweet. An early variety and leaves may be cut when quite small. Our favorite lettuce of all the varieties. Pkt., 10c; oz., 20c; $1 / 4$ lb., 50c: 1b., $\$ 1.40$, postpaid.

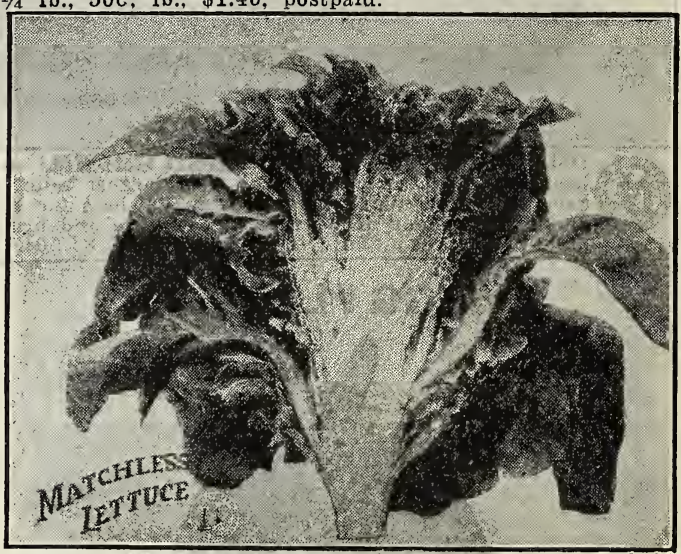

2171/2. MATGHLESS. Oakleaf. A new hybrid, neither a head lettuce nor a loose leaf, but between the two. The leaves are thick and pointed, a sort of Cos lettuce, with the middle of the head inclined to bunch, and the heart very white and crisp. It has a flavor of its own. Pkt., 10c; 0z., 20c; 1/4 lb., 50c; lb., $\$ 1.50$.

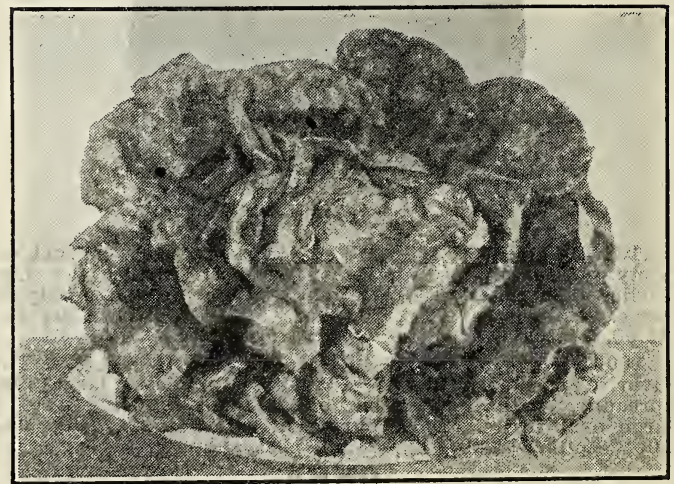

227. TAY May King. head, medium small, light green, tinged slightly at the edges with brown; one of the best early-heading varieties. Pkt., 5c; oz., 15c; 1/4 lb., 45c; lb., \$1.35. postpaid, 


\section{LETTUCE}

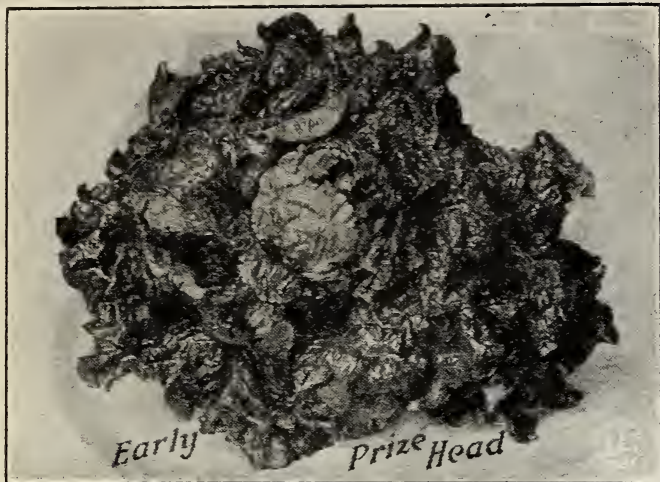

220. \EARLY PRIZEHEAD. One of the best known and most popular varieties in America. It is a curled, crisp, loose leaf lettuce of medium size; color, green over laid with reddish-brown. It is one of the best home varieties as it grows quickly and makes an abundance of crisp leaves of the best flavor. Pkt, 10c; 0z., 20c; $1 / 1$ Ib., 50c; lb., $\$ 1.75$, postpaid.

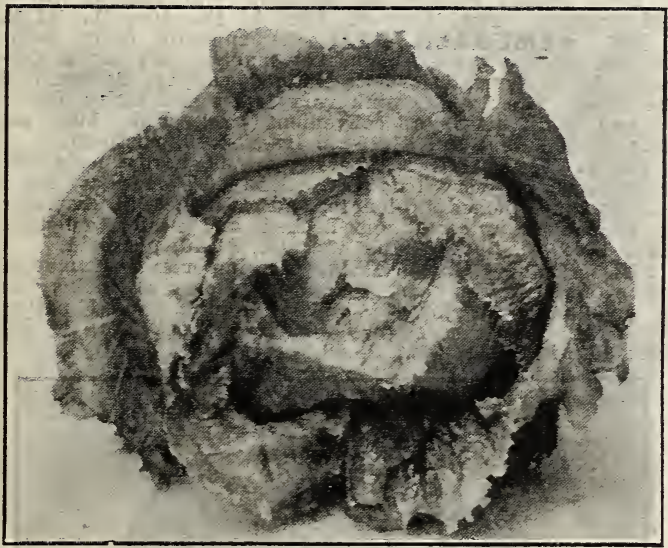

- New York or Wonderful.

218. \NEW YORK OR WONDERFUL, The larg. est head lettuce of all. A new variety that has become immensely popular in the last two rears, especially with the large commercial lettuce growers. It frequently weighs two to three pounds. The heart is very solid and of a pleas ing dark green color. Leaves are large and crumpled. Pronounced the finest in cultivation for exhibition purposes and for an outdoor, all-season variety it stands unrivaled. Ready for market in 60 to 65 days from planting time. The New York or Wonderful is the most popular ship ping variety known. This is the kind you buy in the stores in the winter although they do not always call it by that name. Pkt., 10c; 02., 25c; 1/4 1b., 75c; 1b., $\$ 2.50$.

217. HANSON. One of the best known of the old standard rarieties. Introduced many years ago. It is of the type known as curled-heading; medium size, light green. The leaves are curled and the edges fringed. The best of its class and of excellent quality. Pkt., 5c; oz., $15 \mathrm{c} ; 1 / 4 \mathrm{lb} ., 45 ; 1 \mathrm{~b} ., \$ 1.25$, postpaid.

234. OLDS' LETTUCE MIXTURE. Consists of a splendid assortment and contains early, second early and late lettuce; looseleaf, semi-heading and head lettuce: smooth leaf, curly leaf and notched leaf lettuce: leaves of light green, medium green, dark green and reddish-brown; white seed, gray seed and black seed varieties; in fact, all kinds of lettuce. Will provide a constant succession and large variety at very small cost. Pkt., 5c; oz., 15c; $1 / 4$ lb., $40 \mathrm{c} ; 1 \mathrm{~b}$., $\$ 1.15$, postpaid.

If you are a market gardener, ask for our Market Gardeners' Wholesale Price List.

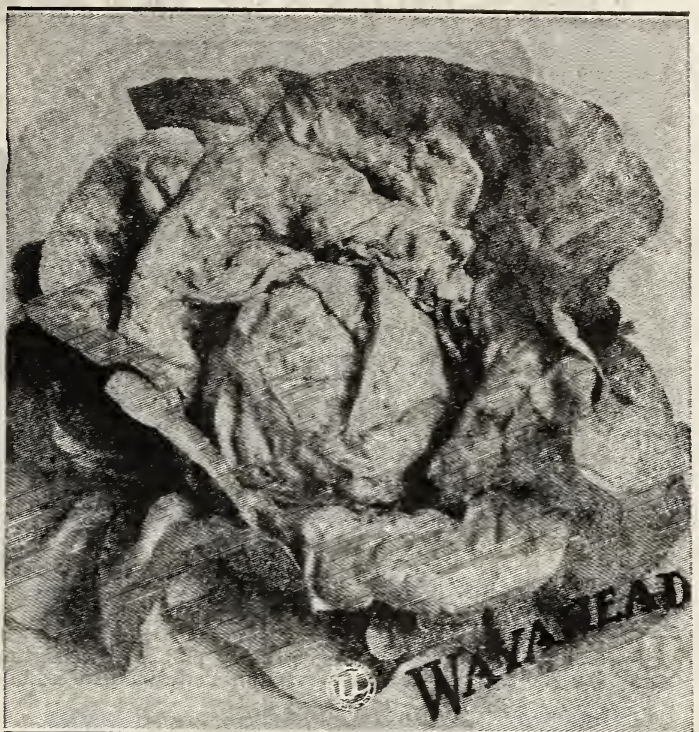

Olds' Wayahead.

Fs? 232. †OLDS' WAYAHEAD. In our trials Way. IDahead has proved to be the vers earliest head let-

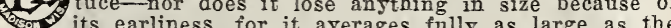
later varieties. The light green leaves are tightly folded, making firm, compact, solid heads that blanch to a rich buttery crispness. The golden yellow hearts are exceedingly tender, brittle and sweet. Does well early or late, in greenhouse, cold frame, or open ground. Pkt., 10c; oz., $20 \mathrm{c} ; 1 / 41 \mathrm{~b}$., $60 \mathrm{c}$; Ib., $\$ 2.00$, postpaid.

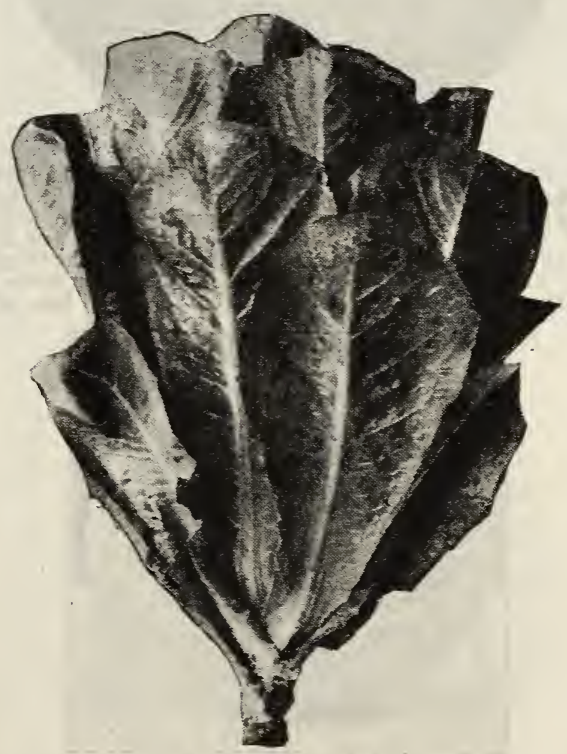

231. PARIS WHITE COS. The aristocrat of the lettuce family. Distinguished by its long, narrow, spoonshaped leaves, folding into loose, long heads. It is the lettuce of the great hotels and restaurants. Just as easily grown as other varieties. Pkt., 10c; 0z., 20c; $1 / 4$ 1b., 50c; ib., $\$ 1.75$, postpacid. 


\section{MUSKMELON}

A packet will plant 10 to 15 hills. Two to three pounds an acre. Do not plant too early. Use fertilizer. Use Slug Shot or the new "Evergreen" for the striped beetle. See page 93 .

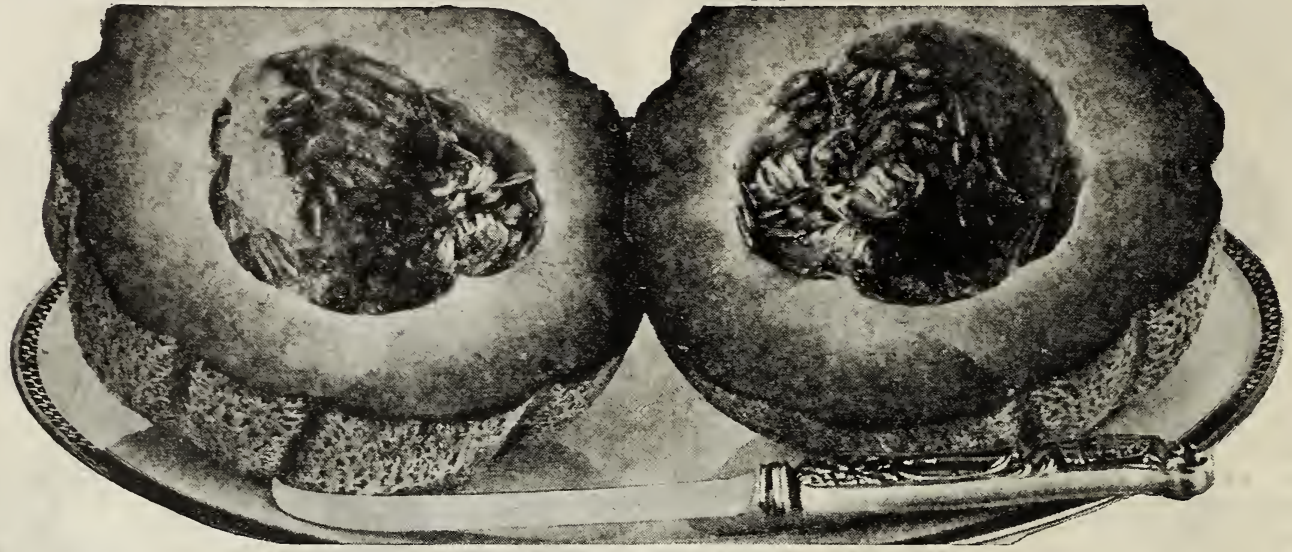

Olds' Rocky Ford.

Fiso 244. OLDS' ROGKY FORD. Rocky Ford is now the most popular and best known of all varieties of muskf Just the right size to serve in halves. It is medium early, with vigorous and productive vines. The melons are almost round, slightly ribbed, densely netted; flesh, green; quality the highest. Our seed is grown for us by the most expert and reliable professional seed growers. Pkt., 1.0c; $0 \mathrm{z}$. $15 \mathrm{c} ; 1 / 4 \mathrm{~b} ., 40 \mathrm{c} ; 1 \mathrm{~b} ., \$ 1.25$.

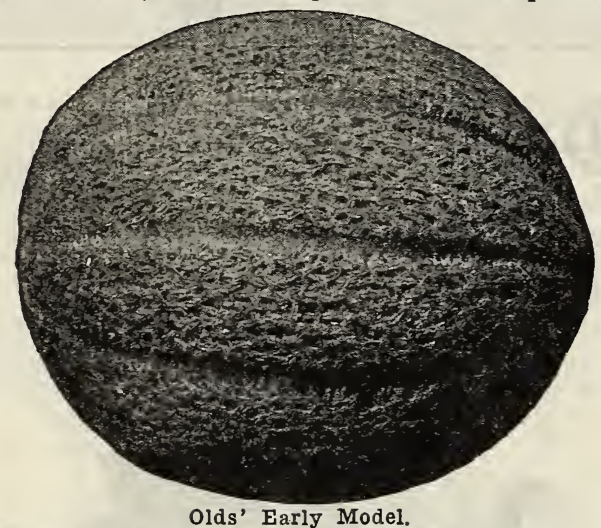

5ase 245. †OLDS' EARLY MODEL. The perfect 100 muskman sweet and delicious in flavor. Very productive. The flesh is green, seed cavity small with few seeds. On account of its size and shape, will bring fancy prices in any market and is also most satisfactory for home use. Pkt., 10c; 0z., 25c; 1/4 lb., 60c; 1b., \$1.75; 5 lbs., $\$ 7.50$.

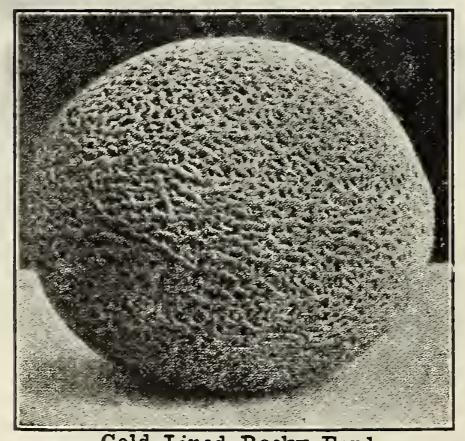

2471/2. GOLD Lold Lined Rocky Ford. type of the green fleshed Rocky Ford, with gold lining next to the seed cavity, making it unusually attractive when cut. Very thick-fleshed, spicy and sweet. Nearly round and completely covered with netting. Pkt., 10c; oz., 15c; 1/4 lb., $40 \mathrm{c}$; 1b., $\$ 1.15 ; 5$ lbs., $\$ 4.50$, postpaid.
238. \EMERALD GEM. A splendid early melon for the kitchen garden or nearby market, but not a shipper. It is a small, smooth-skinned variety, flattened at the ends. The flesh is pink very sweet and highly flavored and the fruit is of convenient size. Pkt., $10 \mathrm{c} ; 0 \mathrm{z}$. $15 \mathrm{c} ; 1 / 4 \mathrm{lb} ., 40 \mathrm{c}$; lb., $\$ 1.25 ; 5$ lbs., $\$ 5.00$, postpaid.

$2481 \frac{1}{2}$. BANANA, A very vigorous, hardy, main-crop melon, growing very long fruits, shaped somewhat like a banana 14 inches in length and 4 inches in diameter. It is banana colored, pink-fleshed and really delicious. Pkt., 10c; 0z., 20c; 1/4 lb., 45c; lb., \$1.40, postpaid.

242. BURRELL'S GEM. An important commercial melon of the Netted Gem type. Second only to Rocky Ford in popularity for long distance shipping. Well netted. Flesh rery sweet and spicy. Pkt., 5c; 0z., 10c; 1/4 lb. $30 \mathrm{c}$; 1b., $\$ 1.00 ; 5$ lbs., $\$ 4.50$, postpaid.

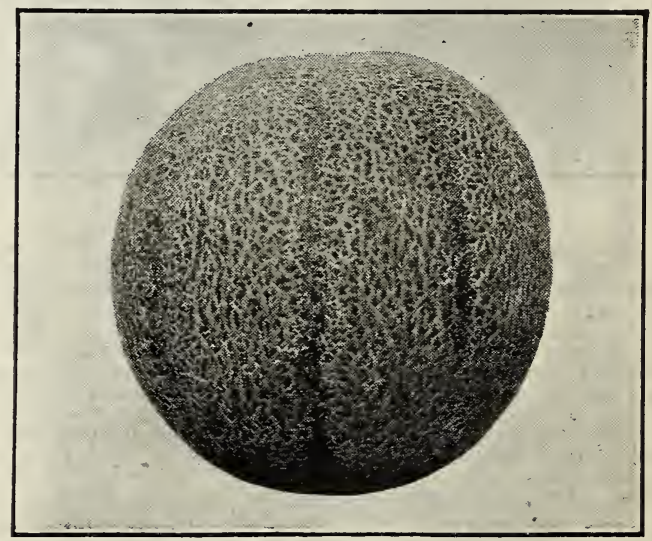

Pollock No. $10-25$

246. POLLOGK NO. 10-25. A new type of Rocky Ford grown largely now not only in the Rocky Ford district as a commercial melon but by home gardeners and market gardeners where a small, salmon-tinted melon is desired. It is a very early melon and of a solid, netted type 'with very small seed cavity, with thick luscious tlesh of genuine salmon tint shading to green near the rind. A splendid keeper and a good shipper. Ripens usually in 75 to 80 days. Pkt., 10c; 0z., 20c; 1/4 lb., 50c; lb., $\$ 1.50$; 5 lbs., $\$ 6.25$, postpaid.

236. EXTRA EARLY HAGKENSACK. An early selection from the old Hackensack and one of the most popular of the extra early green-fleshed varieties. The shape of the melon is flat and the size small, with distinct ribs and netting. Very prolific and hardy and enjoys wide use. The flesh is very sweet and spicy. Pkt., 5c; oz., $15 \mathrm{c} ; 1 / 4$ lb., 35c; lb., $\$ 1.10 ; 5$ lbs., $\$ 4.25$, postpaid. 


\section{MUSKMELON}

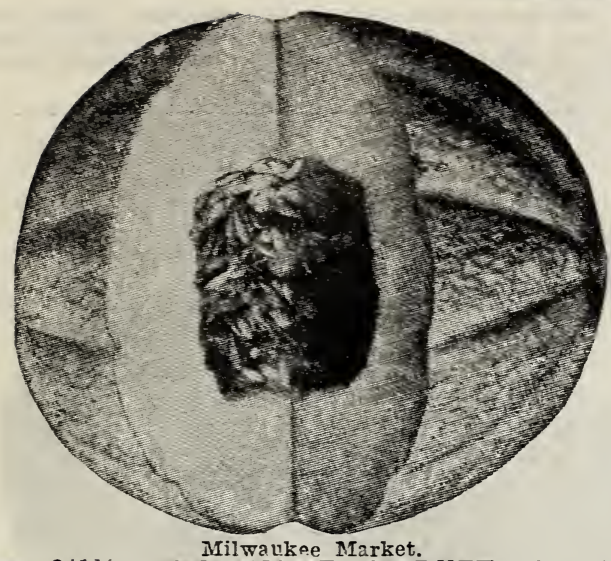

211 $1 / 2$. \MILWAUKEE MARKET. One of the FD : best melons for both market and the home garden. Prolific, rigorous in growth, and unsurpassed in Milwaukee a few years ago and has jumped into prominence. It originated as a cross between the Surprise ant Gem. The skin is light green, fruits nearly round. Flesh a deep salmon color, thick, firm and solid, possessing a rich aromatic flaror; very uniform in size and every melon 5 lbs., $\$ 6.00$, postpaid.

253. HONEY DEW. A distinct melon of the Casaba type. Smooth-skinned, of a light cream color. Late. Tery tender and melting with an extreme sweetness found in no other mel. postpaid.

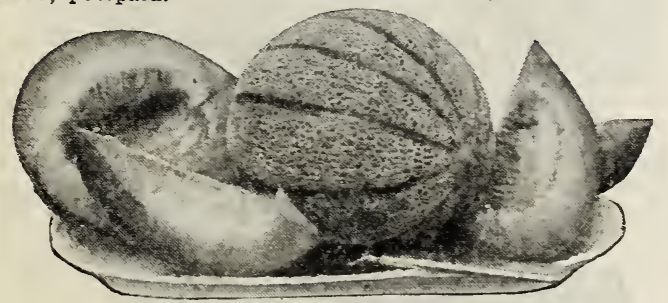

Early Knight.

237. EARLY KNIGHT. (Sweet Air.) Very popular in the East. It is a happy combination of earliness, productireness and quality. The melons are nearly oral in shape; densely netted; of good size, with thick, bright green flesh that is rery luscious. Pkt., 10c; oz., 20c; $1 / 4$ lb., 50c; lb., $\$ 1.50$; 5 lbs., $\$ 6.50$, postpaid.

243. BENDER'S SURPRISE. A delicious, large, salmon fleshed melon with superior shipping and keepin qualities. Fruits oblong, light greenish vellow skin with light netting. Flesh rery sweet. Pkt., 5c; oz., 10c; $1 / 4$ lb., 30c; 1b., \$1.00; 5 lbs., $\$ 1.50$.

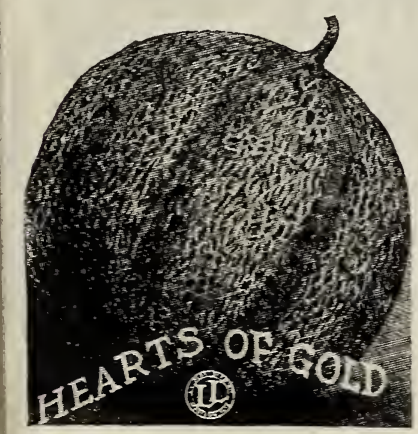

247. HEARTS OF GOLD. (Improven Hoodoo.) One of the finest types of the early, small salmon cellent shipping melon but equally good for home gardens. The melons are round, weighing about 1 , pounds each; lightiy ribbed and corered with a fine grer net ting; flesh rery thick, deep salmon color seed carity remarkably small and flesh sweet and spicy. Pkt., $50 \mathrm{c} ;$ ib $20 \mathrm{c} ; 1 / 4 \mathrm{l}$. Ibs., $\$ 6.00$, postpaid.

2401/2. EXTRA EARLY OSAGE. A week forlier than Osage, the standard high quality melon oz., 20c; 1/4 lb., 50c; lb., $\$ 1.50$, postpaid.

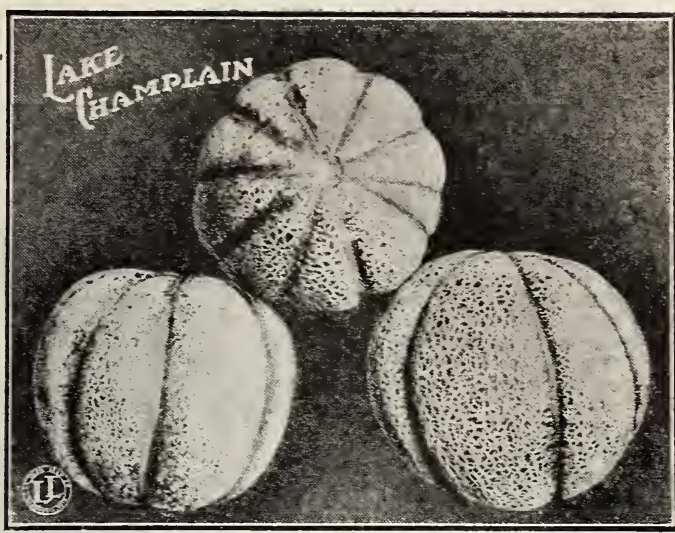

255. HLAKE CHAFPLAIN. The new extra D. early. On our trial grounds, the earliest in fact of on, well netted and with thick orange-hued flesh, honer-street, melting and delicious. It is an extraordinarily heavy rielder and the fruits are of cood size much larger than the Rocky Ford type. Pkt., 10c; 0z., 25c; 1/s lb., $75 \mathrm{c} ; \mathrm{Ib}, \$ 2.00 ; 5$ lbs.. $\$ 8.75$. postpaid.

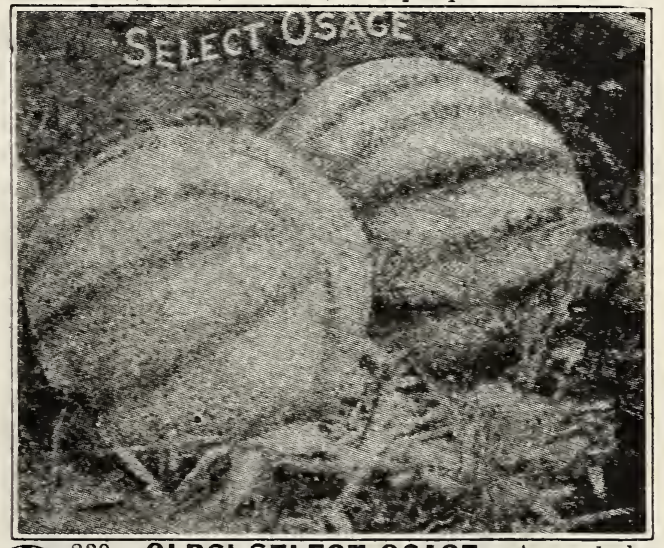

239. OLDS' SELECT OSAGE, An oral shap. Do dod, salmon fleshed melon, unusually thick-meated, ahead of all other rarieties. Pkt., 10c; oz., 20c; $1 / 4$ lb., 50c; lb., \$1.50; 5 lbs., $\$ 6.25$, postpaid.

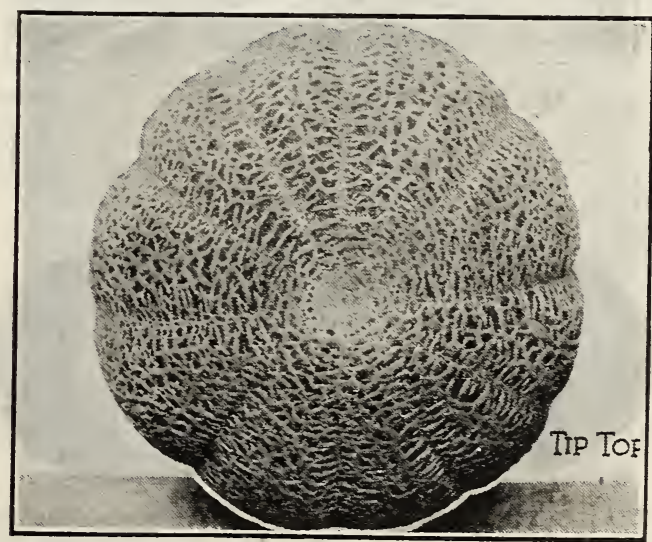

254. TIP TOP. Tip Top in quality, appearance and productireness. Every melon is a good on-sweet juicy, fine flarored and eatable to the rind. Pkt., 10c; 0z., 20c; $-45-$ 


\section{WATERMELON}

Our Watermelon seed is from melons grown exclusively for seed and by seed growers of experience. Each packet contains seed enough for 8 to 12 hills. Four to five pounds will plant an acre. Do not plant too early and plant in sandy soil if possible. It pays well to use fertilizer for melons. There is nothing better than our Truck Gardeners Special. See page 92. Pulverized sheep manure is also splendid for meluns.

263. FORDHOOK EARLY. An extremely early variety and the earliest in fact of all large melons. Perhaps no other variety is so well adapted to the home garden, for it may be planted in hills as close as 6 feet each way. Its value to the home gardener in the north is largely in its earliness. The melons are of good size and nearly round; the skin is dark green with occasional stripes of lighter green. The rind is thin; flesh, bright red, crisp, and remarkably sweet. Pkt., $5 \mathrm{c}$; 0z., 10c; 1/4 1b., 30c; lb., $90 \mathrm{c} ; 5$ lbs., $\$ 1.00$, postpaid. MELON. (Chilean). One of the most desirable of all melons for use in the north. It is early, very attractive in appearance, grows quite large, nearly round, with dark green rind; the flesh is light red, solid, sweet and melting. One of the most worthy of the more recent introductions. Pkt., 5c; oz., 10c; $1 / 4$ lb., 30c; lb., $90 \mathrm{c} ; 5$ lbs., $\$ 4.00$, postpaid.

\section{QUALITY IN SEEDS}

When you buy seeds you want the best. You want not only seeds that will grow but seeds that will produce. We have that kind. Try us and see. Thousands of customers have done just that and they stay with us.

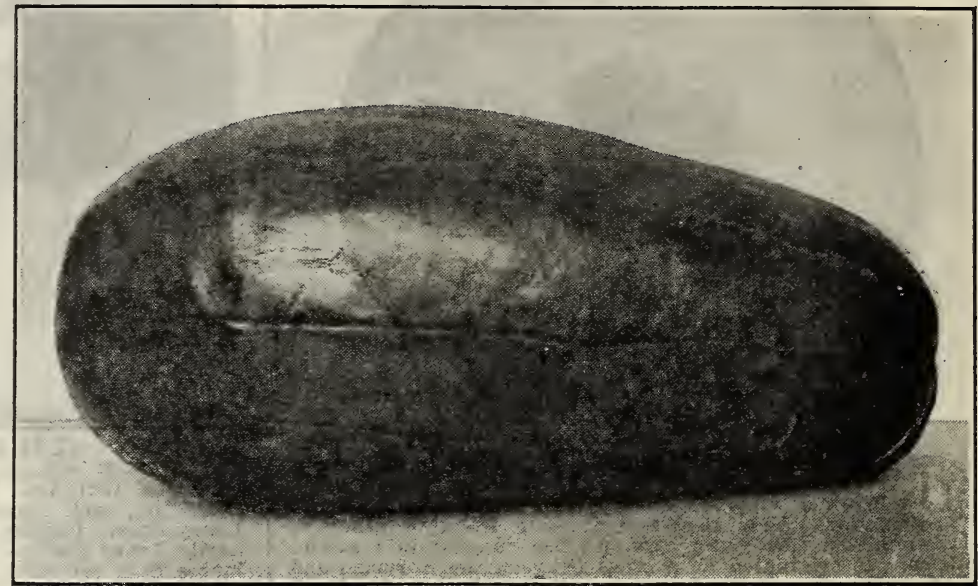

Kleckley's Sweet.

270. ^KLEGKLEY'S SWEET. Monte Cristo. Our best seller of the whole list of watermelons. A fine, well known, medium early variety. It is a medium sized, dark green melon, often growing 20 inches long, with bright red flesh, ripening nearly to the rind. It is solid, crisp and melting; rind thin; flavor, very sweet and pleasing. A wonderfully satisfactory variety for home gardens and nearbr markets but not a good shipper because too brittle. Plant some Kleckley's Sweet in your garden if rou want somthing extra fine, Pkt., 10c; oz., 15c; 1/4 Ib., 35c; lb., $\$ 1.10 ; 5$ Ibs., $\$ 5.00$, postpaid.

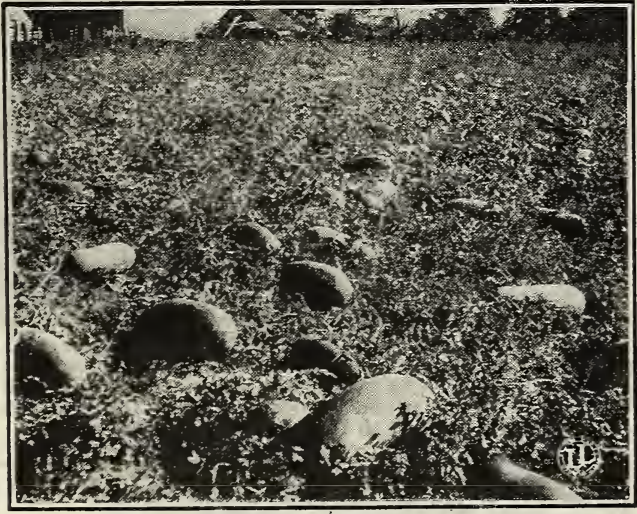

271. Field of Alabama Sweet Watermelons. ing variety with long melons of deep green color, irregularly striped with a darker shade. It is an excellent shipping melon with a very tough elastic rind. The flesh is bright red, fine grained and sweet. Pkt., 10c; 0z., 15c; 1/4 lb., $30 \mathrm{c}$; lb., $95 \mathrm{c} ; 5 \mathrm{Ibs} ., \$ 4.25$, postpaid.

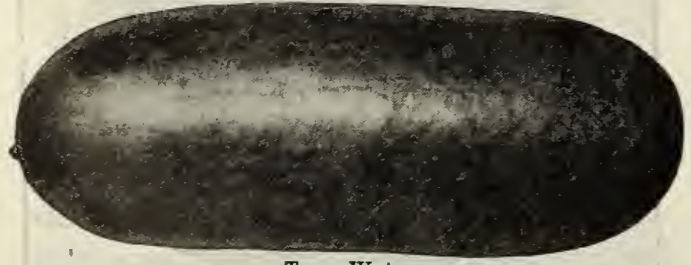

Tom Watson

2711/2. TOM WATSON. The most popular shipping melon, with tough, elastic, dark green rind. It is long and cylindrical, averaging 20 inches in length and 10 inches in diameter. Pkt., 10c; 0z., 15c; 1/4 lb., 30c; lb., 90c; 5 lbs., $\$ 1.25$, postpaid.
267. †ICE CREAM or PEERLESS. A well-known old favorite and a standard home melon. Extra early, of medium size, sliort oblong in form; rind thin, light green in color, mottled and reined with a darker shade; bright scarlet flesh, wonderfully sweet and delicious; seeds white. Ice Cream is an old variety but as good as ever and very hard to beat. It is certainly very highly regarded by thousands of nome gardeners all over the North. It is one of our very best sellers. Pkt., 10c; oz., 15c; $1 / 4 \mathrm{lb}$., $35 \mathrm{c}$; Ib., $\$ 1.00 ; 5$ lbs., $\$ 4.50$, postpaid.

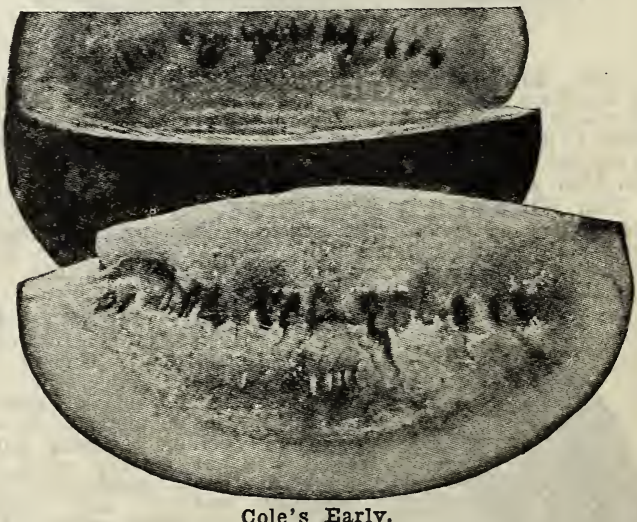

262. $\rightarrow$ GOL'S EARLY. Another home melon that is wonderfully popular all over the North. Our second largest seller. One of the earliest of all melons and one of the best. It is medium in size, nearly round in shape, dark green in color, striped a lighter shade. The flesh is deep pink, rather a darker shade than some others, of excellent quality, firm and delicious. Seeds black. Nothing surer than this variety for hard situations in Northern latitudes. Pkt., 10c; oz., 15c; 1/4 lb., 35c; 1b., \$1.10; 5 lbs. $\$ 5.00$, postpaid.

DON'T FORGET THE ORNAMENTALS

Include some Flower Seeds, some Bulbs and some Plants with your order. Make your home attractive. 


\section{WATERMELON}

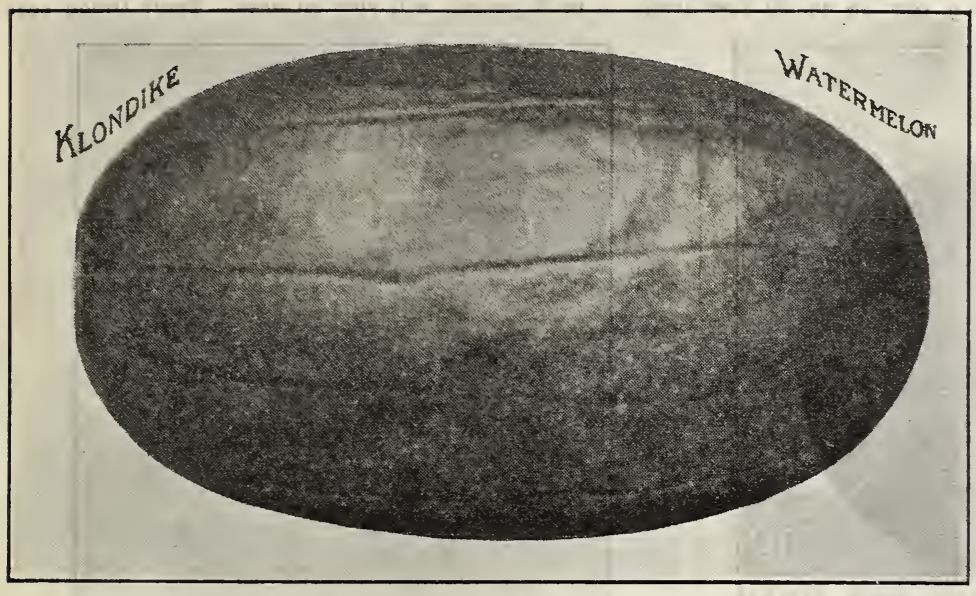

272 $\frac{1}{2}$. GOLDEN HONEY. 'The flesh is a beautiful glistening ambervellow, very tender with a most delicious flavor. It is medium early, of uniform large size, oblong shape and of handsome appearance. The skin is green with irregular stripes of darker green. No hard core or stringy sections. Pkt., $10 \mathrm{c}$; oz., $20 \mathrm{c} ; 1 / 4 \mathrm{lb} ., 40 \mathrm{c}$; 1b., $\$ 1.25$; 5 lbs., $\$ 5.50$, postpaid.

275. CITRON. Colorado Preserving. Perfectly round, striped alternately dark and light green, not edible raw, but excellent for preserves. The flesh is white and hard and the vines very productire. Pkt. 5c; 0z., 15.c; 1/4 1b., 35c; 1b., $\$ 1.00 ; 5$ Ibs., $\$ 4.50$, postpaid.

\section{GARDEN TOOLS}

Look orer our list of Tools, page 88,89 and 90 . We keep in stock the best makes of garden drills, wheel hoes, hand cultivators, fertilizer distributors, garden hoes, rakes, planters, trowels, etc. Pick out what you need and have them shipped with your seeds. 2701/2. \KLONDIKE, One of the best early melons and perhaps the rers sweetest of all melons. The and tender, ripens rerr earlr and so is adapted to northern states. It is also a heavy yielder. Pkt., 10c; oz., $15 \mathrm{c} ; 1 / 4 \mathrm{lb}$., 35c; lb., $\$ 1.10 ; 5$ lbs., $\$ 5.00$, postpaid.

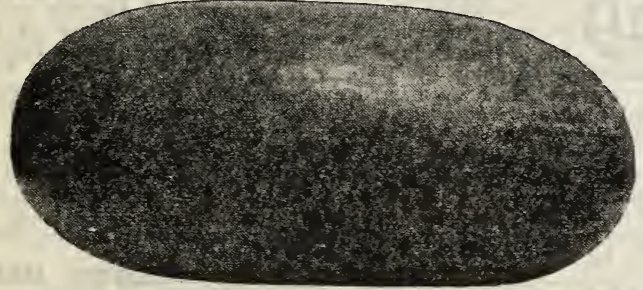

Irish Grey.

268. IRISH GREY. A long, rather large melon, ligh green in color and of fine table quality. The flesh is deep red, crisp and sweet and without a hard center. Besides being a fine garden melon, it is equal to Tom Watson as a shipper. Pkt., 10c; 0z.. 20c; 1/4 lb., $40 \mathrm{c} ; 1 \mathrm{~b} ., \$ 1.25 ; 5$ lbs., $\$ 5.50$, postpaid.

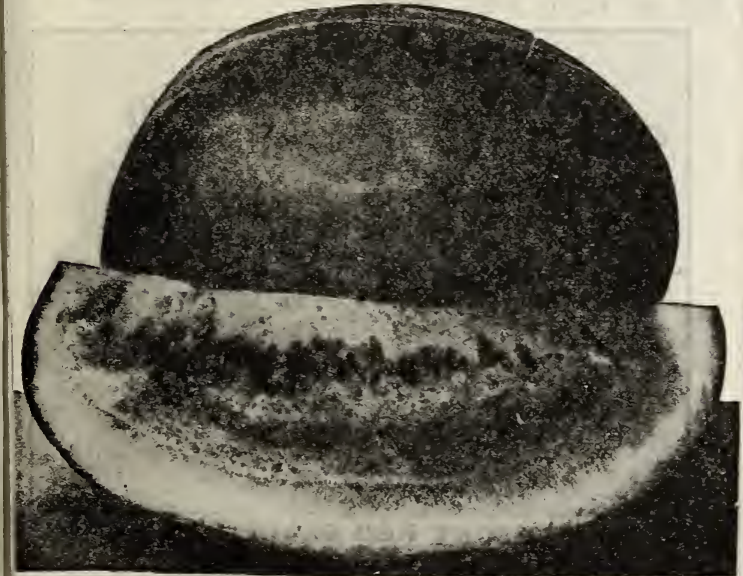

Sweetheart.

261. SWEETHEART. A large oval melon, medium early in season. Remains in condition for use longer than any other except the Winter Melon. The flesh is bright red, solid and sweet. Rind thin but tough and elastic, making it a good shipper. A very popular variety. Pkt., $10 \mathrm{c} ;$ oz., 20c; 1/4 lb., $40 \mathrm{c}$; 1b., $\$ 1.25 ; 5$ lbs., $\$ 5.50$, postpaid.

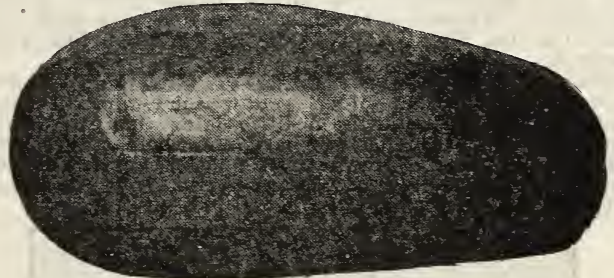

Halbert Honey.

273. tHALBERT HONEY, Another good, medium early melon for hom use. In flavor, color and texture, similar to Kleckley's Sweet. Medium to large in size, oblong in shape; color, dark green, lightly laced with fine veins flesh, sweet and brittle; too thin a rind for shipping but desirable for the garden. Pkt., $10 \mathrm{c} ; 0 \mathrm{z} ., 15 \mathrm{c} ; 1 / 4 \mathrm{Ib}, 35 \mathrm{c}$. lb., $\$ 1.00 ; 5$ lbs., $\$ 4.50$, postpaid.

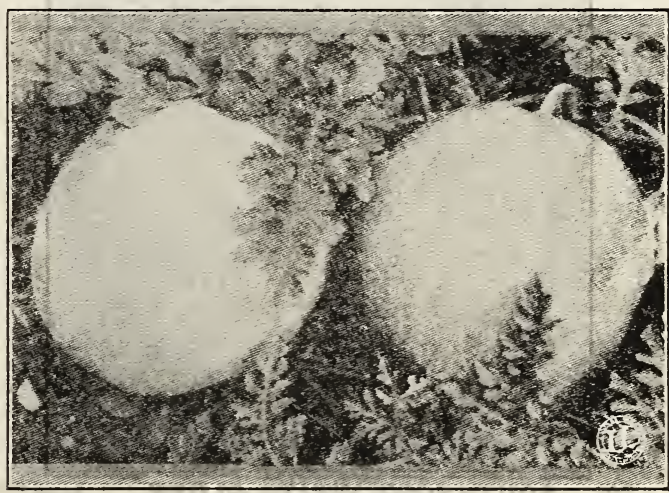

Olds' Winter Melon.

DST 2761/2. OLDS' WINTER. This melon is early, T Trery prolific, almost round and in color, light green. 1. The flesh is red, sweet and almost as hard as a citron. If properly stored will keep for months. Pkt., 10c; oz., 20c; 1/1 1b., 35c; 1b., \$1.10; 5 lbs., $\$ 5.00$.

\section{INSEGTICIDES AND FUNGIGIDES.}

You will find a complete list of Insecticides and Fungicides on page 93 of this catalog. Order what you need to come with your seeds. 
Our Onion seed is all tested seed and shows high germination. Prices are very reasonable this year. Each packet contains seed enough to sow a row 25 to 30 feet long. 4 to 5 pounds will sow an acre. Treat Onion seed with Semesan. See page 28.

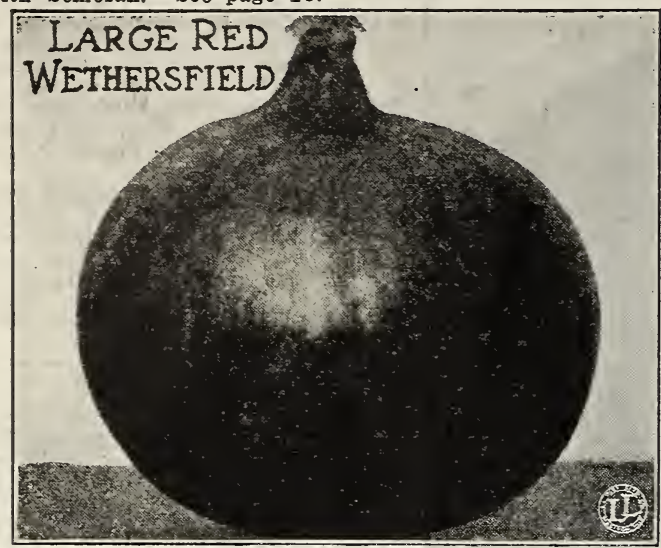

6PIPT 287. OLDS' EXTRA LARGE RED WETH. TT: ERSFIELD. Red Wethersfield is a fine old American variety, originated long before the Civil Wa onions are a flattened globe in shape with long slender tops and dark crimson skin. They grow to a large size and rield big crops even under unsatisfactory growing conditions. We have a strain selected for extra large type. Pkt., 10c; 0z., 25c; 1/4 lb., 70c; 1b., \$2.00; 5 lbs., $\$ 9.25$, postpaid.

290. SOUTHPORT YELLOW GLOBE. A globe shaped onion of fine golden yellow color, growing some what larger and maturing a little later than the Yellow Globe Danvers. The flesh is hard and compact yet brittle and crisp. Largely grown as a market onion and most profitable. Pkt., 10c; oz., 25c; $1 / 4$ lb., 75c; lb., $\$ 2.25$; 5 lbs., $\$ 10.50$, pestpaid.

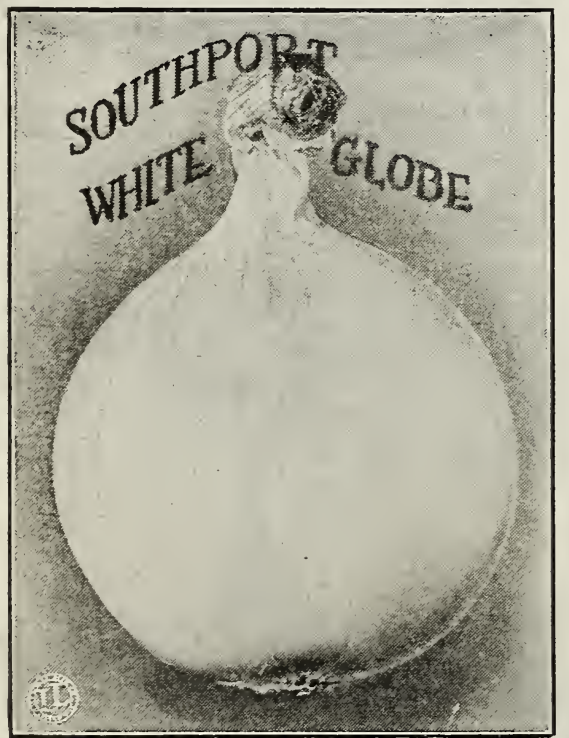

292. SOUTHPORT WHITE GLOBE, A hand some onion with a pure delicate paper white skin. Flesh crisp, fine-grained, snowy white and mild; globe shaped and a good keeper for a white kind. Most retail customers prefer a white onion and we consider this as unquestionably the best white market variety. Pkt., 10c; oz., 35c; $1 / 4$ lb., $\$ 1.15$; lb., $\$ 3.50 ; 5$ lbs., $\$ 16.50$, postpaid.

283. CRYSTAL WAX. One of the most attractire varieties It is large, pure white, very early, mild in flavor; in fact can be eaten like an apple. Can be grown under nortlern conditions and is very fine for slicing. PEt., 15c; 0z., 55c; 1/4 lb., \$1.65; lb., \$5.00, postpaid.
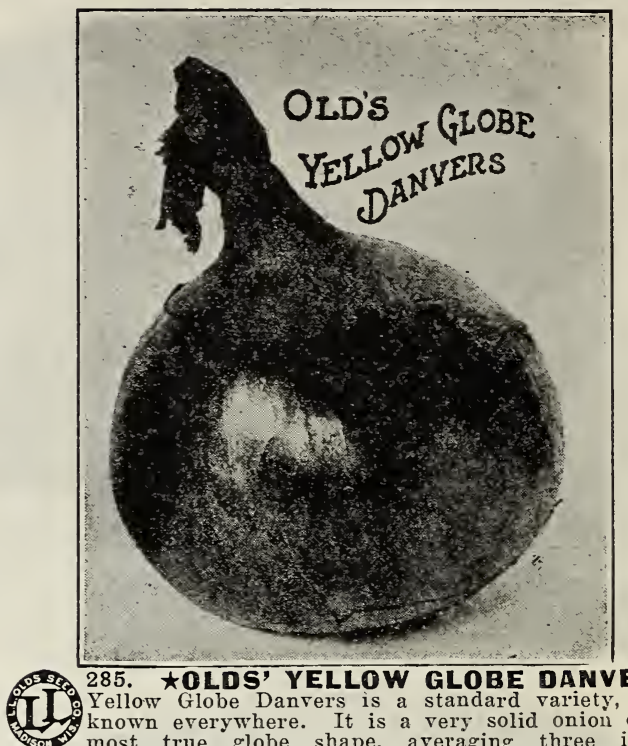
285. ‡OLDS' YELLOW GLOBE DANVERS. Yellow Globe Danvers is a standard variety, wellknown everywhere. It is a very solid onion of almost true globe shape, averaging three inches through. In color the bulbs are a rich satiny yellow. The snow-white flesh cuts hard and crisp yet it is always sweet and tender. Not quite as mild as the Spanish onions when sliced raw but for cooking or flavoring, one of the best.

It is the earliest good market variety, slender necked, and ripening up all at one time. A sure cropper and a good keeper, the onions coming out dry and hard in the spring with practically no loss in weight. We have a specially choice strain. Pkt., 10c; oz., 25c; 1/4 lb., 75c; lb., $\$ 2.25 ; 5$ lbs., $\$ 10.50$, postpaid.

285 $\frac{1}{2}$. MILE HIGH YELLOW GLOBE DAN. VERS A very handsome type of Yellow Globe Danvers grown in the Colorado high altitude. Mile High Yellow Globe Danvers is probably the best for shipping and the best keeper of all varieties of onions. It is also more productive than most sorts. It is claimed that the territory from which our seed comes has never been affected by mildew or any of the diseases or insects that are common in most onion growing sections. Pkt., 10c; oz., 30c; $1 / 4 \mathrm{lb}$., $90 \mathrm{c}$; 1b., $\$ 2.75 ; 5$ lbs., $\$ 12.50$.

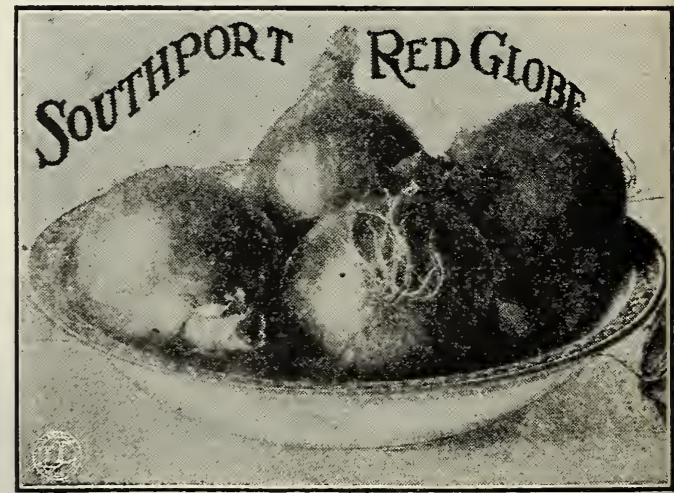

291. SOUTHPORT RED GLOBE. Southport Red Globe is a large, handsome, dark red onion with small neck, small top and of mild flavor. The finest type of red onion and the most popular one with market gardeners. Pkt. $10 \mathrm{c}$; oz., 25c; 1/4 lb., 75c; lb., \$2.25; 5 lbs., $\$ 10.50$.

299. AUSTRALIAN BROWN. Noted for its fine keeping qualities and also for its peculiar brown color. Without any exeeption the most solid and longest keeping onion grown. A nieasured bushel will weigh several pounds more than the standard legal weight. Pkt., 5c; oz., 20c; $1 / 4$ lb., 60c; 1b., $\$ 1.75 ; 5$ lbs., $\$ 8.00$, postpaid. 


\section{ONION}

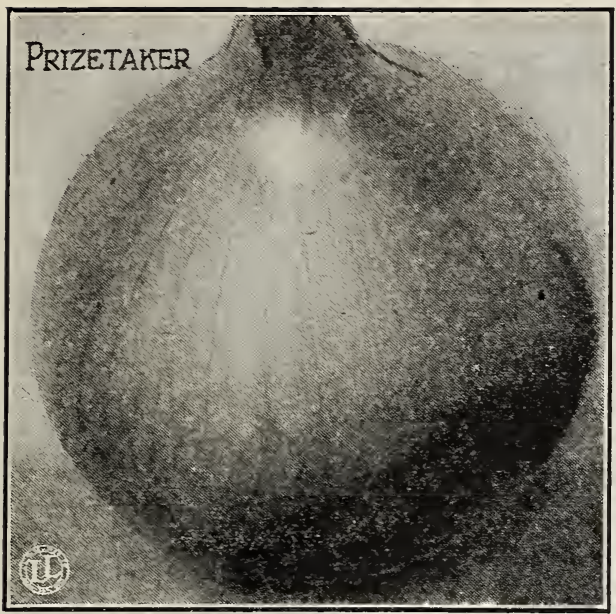

297. OLDS' PRIZE-TAKER. One of the O largest and mildest of onions. Yery popular. 1t might almost be called an American onion for it the original seed coming from Spain. Bright straw vellow in color and a good globe shape. Grows three times as large as Danrers, individual onions sometimes weigh ing four pounds and orer. Pkt., 10c; 0z., 25c; $1 / 4$ lb.,

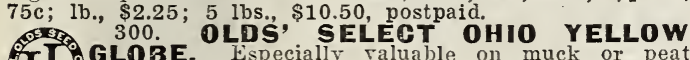
TIOLOBE, shape than the Danvers. Pkt., 5c; oz., 20c; 1/4 lb., 70c; lb., $\$ 2.15$; 5 lbs., $\$ 10.00$, postpaid.

2971/2. GIGANTIC GIBRALTER. The largest mildest and sweetest of all onions. Creamy straw colored bulbs, excellent for slicing, nerer strong, but brittle, juicy and with a rery pleasant flavor. Pkt., $10 \mathrm{c}$; 0z., 30c; $1 / 4$ lb., $\$ 1.00$; lb.. $\$ 3.00$, postpaid.

293. WHITE PORTUGAL. (Silver Skin.) A handsome early onion with silvery white skin. Grows about as large in diameter as the Southport Globes but flat. The fillest small white sets are grown from this variety. Pkt., 10c; oz., 30c; $1 / 4$ lb., 95c; lb., $\$ 3.00 ; 5$ lbs., $\$ 14.25$, postpaid.

303. OLDS' WHITE QUEEN. A rery hardy per ennial variety of onion, used for bunching and pickling. It is perfectly hardy and requires no mulching. Sow in early fall for early spring onions. Pkt., 10c; oz., 30c; 1/s lb., $90 \mathrm{c}$; 1b., $\$ 3.00$, postpaid.

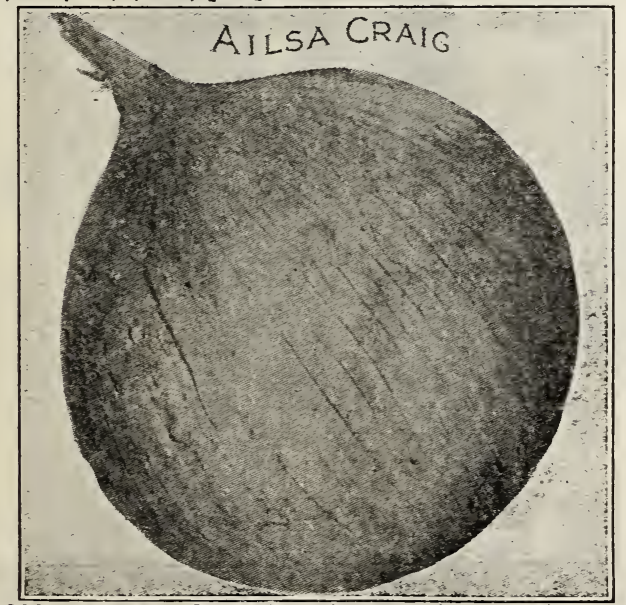

288. AILSA CRAIG An exhibition variety An English strain of Spanish onion, much like the Prize-Taker but a considerably better keeper. A fine salad kind, mild. ly pungent, sweet and juicy. Yellow skin. Pkt., 10c; oz., $25 \mathrm{c} ; 1 / 4$ Ib., $80 \mathrm{c}$; 1b., $\$ 2.50 ; 5$ Ibs., $\$ 11.75$, postpaid.

\section{OLDS' ONION SETS}

We offer choice, dry, select Onion Sets, the best to be had. Bottom sets should be planted very early in the spring, the earlier the better. A pound will plant a row 20 feet long, two to three inches apart in the row. Egyptian or Winter Sets should be planted in the fall.

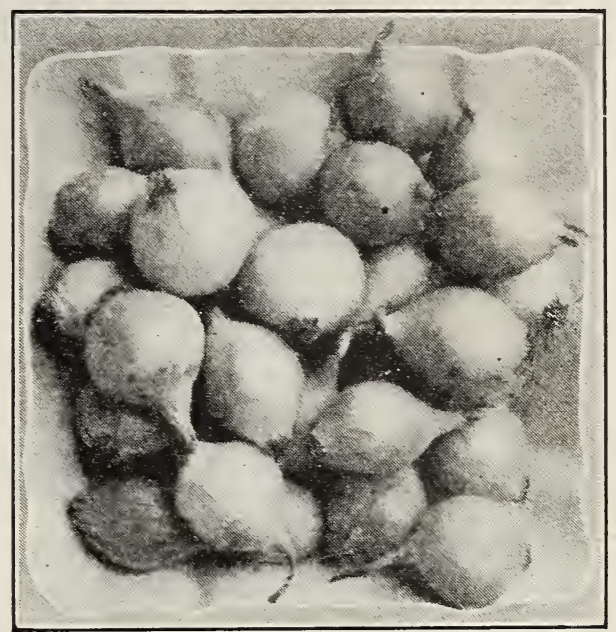

Yellow Bcttom Onion Sets.

YELIOW BOTTOM SETS: Ib, 30c; 4 lbs, 90c, postpaid. By express: 10 lbs., \$1.25; bu. (32 lbs.), \$3.50. RED BOTTOM SETS: 'Lb., 30c; 4 lbs., 90c, postpaid. By express: $10 \mathrm{lbs}$., $\$ 1.25$; bu. (32 lbs.), $\$ 3.50$

WHITE BOTTOM SETS: Lb., 35c; 4 lbs., $\$ 1.10$, postpaid. By express: $10 \mathrm{lbs} ., \$ 1.40$; bu. (32 lbs.), $\$ 4.00$.

EGYPTIAN or WINTER SETS, for fall delivery only: Lb., 30c; 2 lbs., 55c; 4 lbs., $\$ 1.00$, postpaid. By express: 10 lbs., $\$ 1.40$; bu. (28 lbs.), $\$ 1.00$.

Bushel Prices of Onion Sets are subject to change after Feb. 1st. IVrite for prices.

\section{FROST PROOF ONION PLANTS}

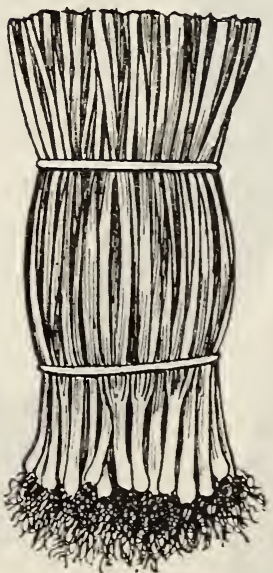

Southern Grown Frost Proof Onion Plants have been giring satisfactory result for some rears and are well out of the experimental class. They are grown by experts and properly packed so that they will reach the customers in good condition. The seed is planted in the fall, they grow out of doors during the winter so they are hardy and are ready to be planted early.

One thing sure, you will hare to hand weed rour onion patch at least once during the season if you plant seed. If you use plants, either of your own growing or our southern grown, you can cultivate and keep ahead of the weeds. The rarieties we offer are, Crystal White Wax and Yellow Bermuda.

Prices: $100,35 \mathrm{c} ; 200$ $65 \mathrm{c} ; 500, \$ 1.50 ; 1,000$ $\$ 2.75 ; 2,000, \$ 5.00$, postpaid Frost Proof Onion Plants. Not prepaid, crate of 6,000 $\$ 7.50$.

\section{CHIVES.}

279. Chires belong in the perennial class. Plant the eed the same as onions, but transplant later, leaving about six to eight inches between plants. Milder than onions with smaller tops. Seed: Pkt., 10c; oz., 25c. Strong Plants: 3 for $50 \mathrm{c} ; 12$ for $\$ 1.50$

\section{GARLIC.}

Garlic comes in bulbs only, which should be separated and planted the same as onion sets and cultivated in the same way. Bulbs, $1 / 4$ lb., $25 \mathrm{c}$; lb., $60 \mathrm{c}$, postpaid. 


\section{PEAS}

Our large two ounce packets will plant 10 to 15 feet each; one pound will plant 75 to 100 feet; an acre requires 90 to 120 pounds. Those marked thus $\left(^{*}\right)$ are wrin kled varieties and are sweeter than the smooth varieties.

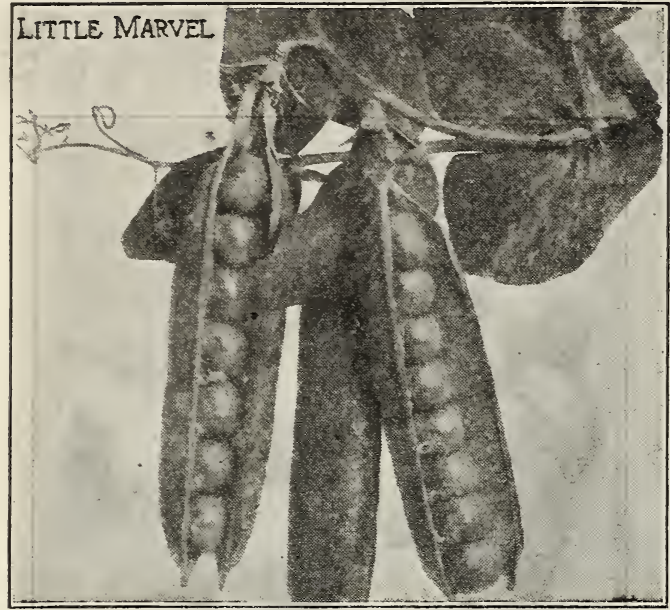

Little Marvel.

339. ‡LITTLE MARVEL. * A dwarf early pea of unusual value. The vines average 15 inches in height and the pods 3 inches or more in length. Pods contain 6 to 7 large, dark green peas, sweet and delicious. They produce a larger pod and a heavier crop than other extra earlies. Large pkt. (2 ozs.), 10c; $1 / 2$ lb., 25c; lb., $45 \mathrm{c} ; 2$ lbs., $80 \mathrm{c}$; 5 lbs., $\$ 1.50$, postpaid. Not prepaid, $10 \mathrm{lbs}$. or more at $21 \mathrm{c}$.

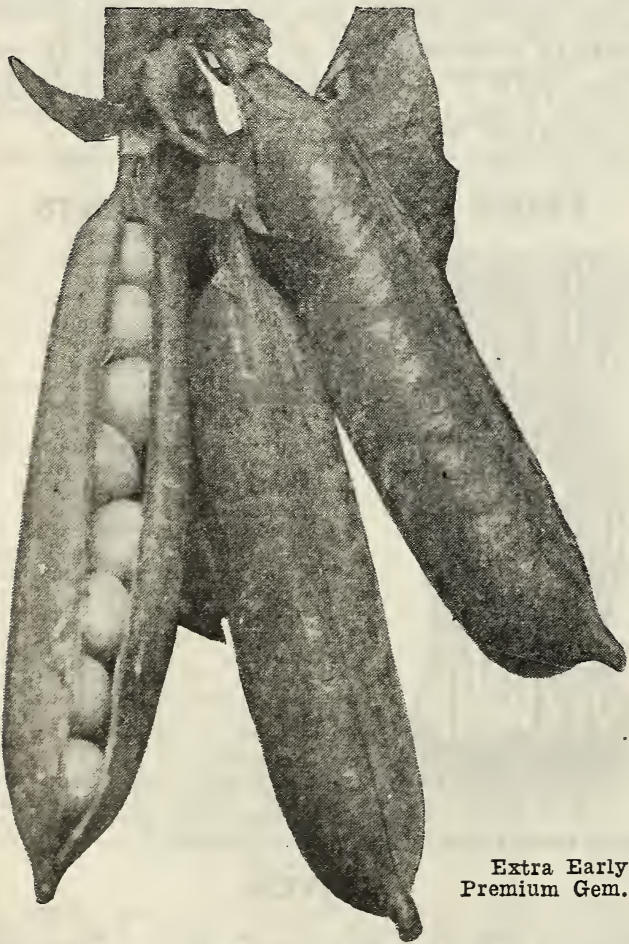

320. EXTRA EARLY PREMIUM OR LITTLE GEM.* Probably the most popular of all peas for the home garden. The vines grow to about 15 inches in height. The variety is very productive and the peas of fine flavor. Considered by many the sweetest of all early peas. Large

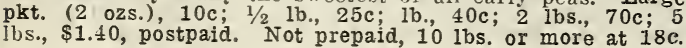

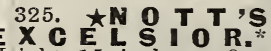
Height 15 inches. One of the most popular peas in cultivation. It is as early as American Wonder, as sweet as Little Gem and outvields both of them. The vines are vigorous in growth, the pods large and square at the ends, and the flavor delicious. Large pkt. (2 ozs.), 10c; $1 / 2$ lb., $25 \mathrm{c} ; 1$ lb., $40 \mathrm{c}$; 2 lbs., 70c; 5 lbs., prepaid, $10 \mathrm{lbs}$. or more at $20 \mathrm{c}$.

320. SURPRISE OR EGLIPSE: : One of the earliest wrinkled peas. Pods of good size and well filled with tender, sweet peas. Iarge pkt. (2 0zS.), 10c; $1 / 2$ lb., $25 \mathrm{c}$; 1b., 40c; $21 \mathrm{bs}$., $70 \mathrm{c}$, postpaid. Not prepaid, $10 \mathrm{lbs}$. or more at $18 \mathrm{c}$.

323. A L A S K A. Earliest of all. The vines grow to 30 inches in height. Matures practically the entire crop at one time. The most popular early pea for canning. Large plst. (2 ozs.), 5c; $1 / 2$ 1b., $15 \mathrm{c}$; 1b., 25c; 2 lbs., $45 \mathrm{c}$, postpaid. Not prepaid, 10 Ibs. or more at $15 \mathrm{c}$.
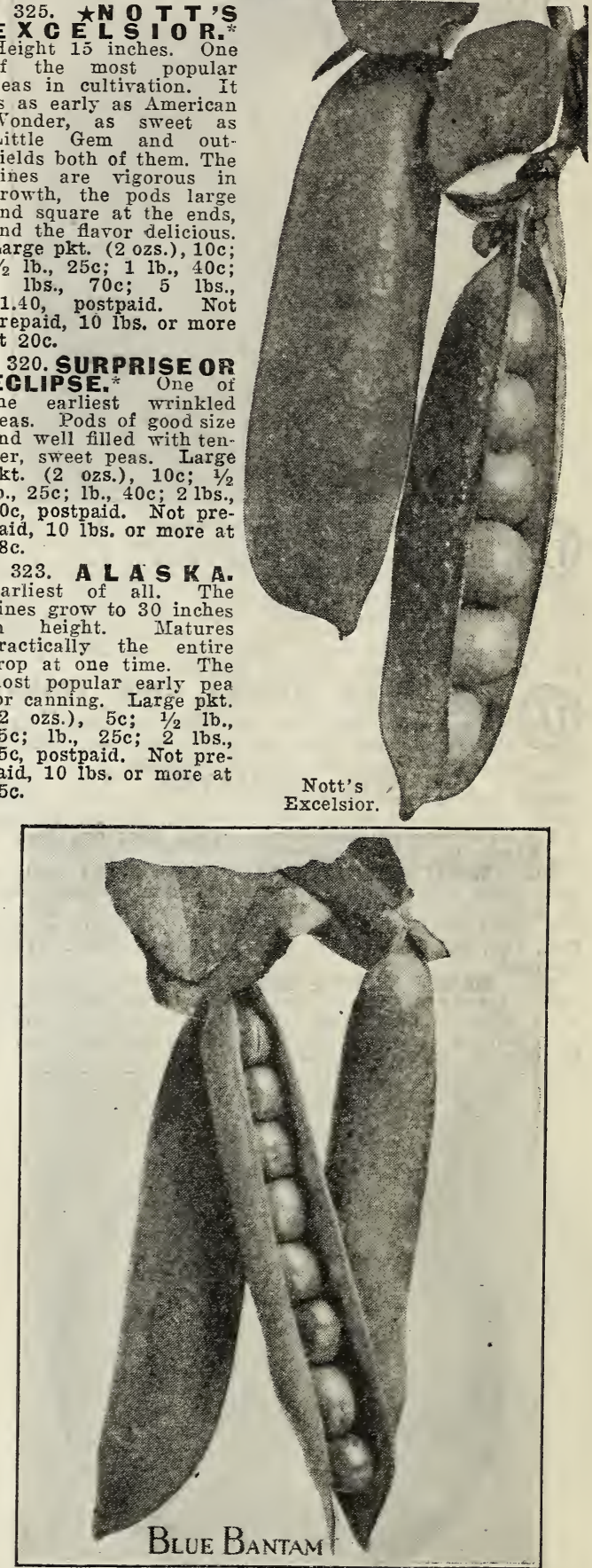

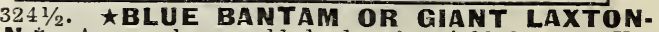
IAN.* A new large-podded, dwarf wrinkled pea. Unequaled for its combination of extreme earliness, snperb quality, and unusual productiveness. The dwarf vigorous vines average 15 inches in height and carry really enormous crops of large pods. Pkt., $10 \mathrm{c} ; 1 / 2 \mathrm{lb} ., 25 \mathrm{c}$; 1b., $45 \mathrm{c}$; 2 lbs., 80c, postpaid. Not prepaid, $10 \mathrm{lbs}$. at $23 \mathrm{c}$. 


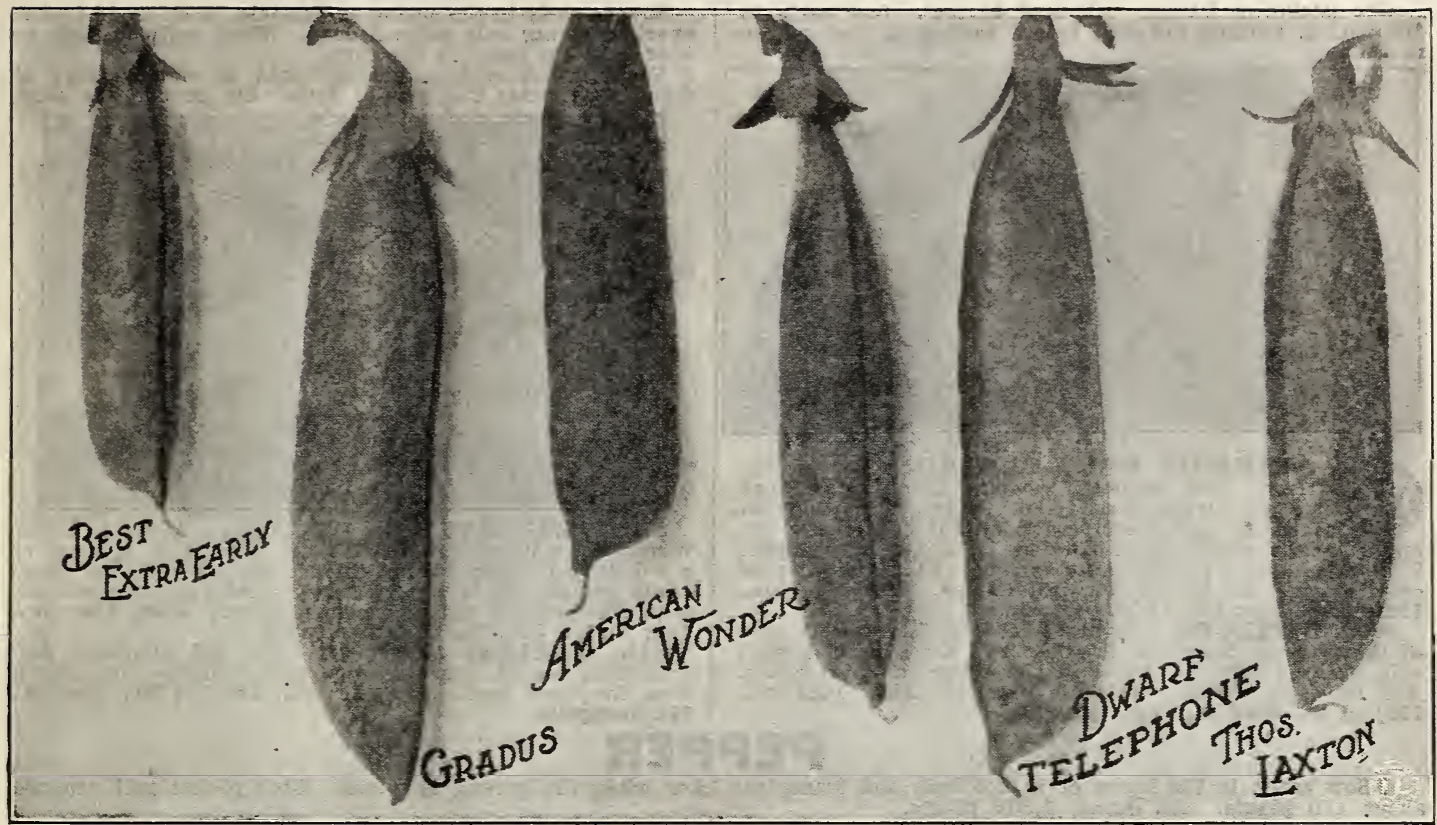

(1)

3201/2. ‡OLDS' BEST EXTRA EARLY. Ai extra early round-seeded variety, largely grown er peas. $75 \%$ to $80 \%$ Ripens more erenly than oth. at the first picking. Large plat. (2 ozS.), 10c; $1 / 2$ lb., 20c; lb., 35c; 2 lbs., 60c; 5 lbs., $\$ 1.25$, postpaid. Not prepaid, $10 \mathrm{lbs}$. or more at $15 \mathrm{c}$.

324. †GRADUS. * Prosperity. This pea is nearly as early as the small, smooth, extra early varieties and the pods are much larger. The rine grows to a height of abo: 30 inches. Pods measure 4 inches or more in length containing 8 or 10 sweet and fine flarored peas. Large pkt. (2 ozs ), 10c; 1/2 lb., 25c; 1b., 45c; 2 lbs., $80 \mathrm{c} ; 5$ lbs. $\$ 1.50$, postpaid. Not prepaid, $10 \mathrm{lbs}$. or more at $20 \mathrm{c}$.

330. AMERICAN WONDER * The dwarfest of all peas, vines growing only about 10 inches high. It is also one of the very earliest, the peas often being ready for use within seren weeks from planting. Add to these attractive features, its fine flavor and its great vield for so small a rine, and its great popularity is explained. A cross between Champion of England and Little Gem. Large pkt. (2 ozs.), 10c; $1 / 2$ lb., $25 \mathrm{c}$; 1b., $40 \mathrm{c} ; 2$ lbs., $70 \mathrm{c} ; 5$ lbs., $\$ 1.40$, postpaid. Not prepaid, $10 \mathrm{lbs}$. at $20 \mathrm{c}$.

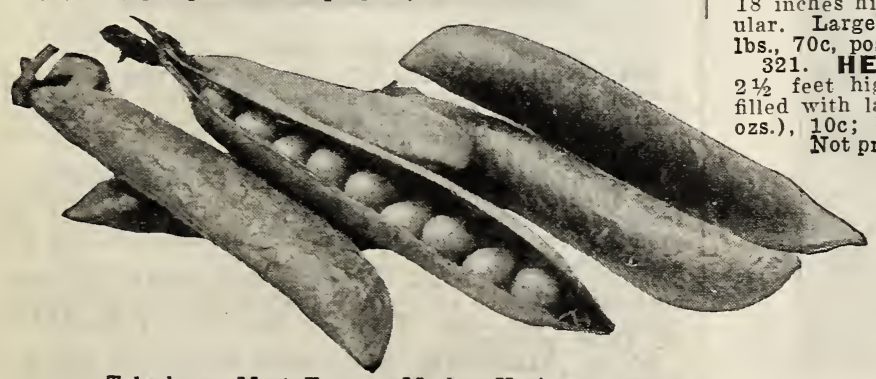

Telephone, Most Famous Market Variety.

322. †IMPROVED TELEPHONE. * Vines, 4 feet high; pods, dark green, $3 \frac{1 / 2}{2}$ to 4 inches long; containing from 5 to 10 peas each. The leading variety among market gardeners. Comes into bearing in about 65 days. Yields abundantls, sweet and luscious peas. Iarge pist. (2 ozs.) 10c: 1/2 1b., 25c; 1b., 40c; 2 lbs., 75c; 5 lbs. $\$ 1.35$, postpaid. Not prepaid, $10 \mathrm{lbs}$. or more at $18 \mathrm{c}$.
335. †OLDS” DWARF TELEPHONE.* (Carter's Daisy.) A cross of Stratagem and Telephone, growing about 18 inches high. but the rines being strong and thrift require no support in spite of the load of large pods. The pods are nearly double the size of such peas as American Wonder and Little Gem, and the quality is 2 lbs. $70 \mathrm{c}$. postpaid. Not prepaid, $10 \mathrm{lbs}$. at $20 \mathrm{c}$.

334 . THOMAS LAXTON.* In earliness only two or three dars behind Alaska, and in yield and quality far superior. The pods contain sweet, large peas of fine flaror. $70 \mathrm{cos}$. Not prepaid, $10 \mathrm{lbs}$. or more at $18 \mathrm{c}$.

$333 \frac{1}{2}$. ALDERMAN.* Many consider this the best of the early main crop peas of the Telephone type. The pods are of the largest size, $4 \frac{1 / 2}{2}$ to 5 inches in length and Tines grow $31 / 6$ to 4 feet in height. Large pkt. ( 2 ozs.), 10c; 1/2 1b., 25c; 1b., $40 \mathrm{c}$; 2 lbs., $70 \mathrm{c}$, postpaid. Not prepaid, $10 \mathrm{lbs}$. or more at $18 \mathrm{c}$

333. `OLDS' ENGLISH WONDER, * This new, dwarf second-early rariety is the sweetest pea we know of The pods are produced in abundance and are $w^{3}$ fili writh large, dark-green peas. The rines grow about 18 inches high and require no support. Proving very poplar. Large pkt. (2 ozs.), 10c; $1 / 2$ 1b., $25 \mathrm{c}$; 1b., $40 \mathrm{c}$; costpaid. Not prepaid, $10 \mathrm{lbs}$. or more at $19 \mathrm{c}$

HEROINE* A good second early. The rines. $21 / 2$ feet high, bear profusely large handsome pods, well filled with large, sweet peas of fine flaror. Large pkt.
ozs.), $10 \mathrm{c} ; 1 / 2 \mathrm{lb}$., $20 \mathrm{c} ; 1 \mathrm{~b} ., 35 \mathrm{c} ; 2 \mathrm{lbs}$., $60 \mathrm{c}$, postpaid. Not prepaid, $10 \mathrm{lbs}$. or more at $18 \mathrm{c}$.

\section{IMPROVED STRATAGEM.} The best of all the large podded, late peas. The foliage is large, and the rines about 20 inches tall, ordinarils requiring no support Very prolific. Large pkt. (2 ozs.), $10 \mathrm{c} ; 1 / 2$
lb., $25 \mathrm{c} ;$ lb., $40 \mathrm{c} ; 2$ lbs., $70 \mathrm{c}$, postpaid. Not prepaid, $10 \mathrm{lbs}$. or more at $20 \mathrm{c}$

327. CHAMPION OF ENGLAND.* rery sweet pea. Has been ralued for man vears as a standard main crop rariets. Th of 4 to 5 feet. Large pkt. ( 2 ozs. $), 5 \mathrm{c} ; 1 / 2 \mathrm{lb}$., $15 \mathrm{c}$; $1 \mathrm{~b}$. $25 \mathrm{c} ; 2$ lbs., $45 \mathrm{c}$, postpaid. Not prepaid, $10 \mathrm{lbs}$. at $16 \mathrm{c}$.

341. MAMMOTH LUSCIOUS SUGAR. These peas are not shelled but pod and all eaten like Strin Beans. The pods are stringless, brittle and fine flavored. Large pkt. (2 ozs.), 10c; 1/2 lb., $25 \mathrm{c} ; 1 \mathrm{~b} ., 15 \mathrm{c} ; 2$ lbs., $80 \mathrm{c}$ postpaid. Not prepaid, $10 \mathrm{lbs}$, or more at $20 \mathrm{c}$ 


\section{PARSLEY}

One packet of Parsley will seed 40 feet. Sow early in the spring, soaking the seed before sowing as germination is slow.

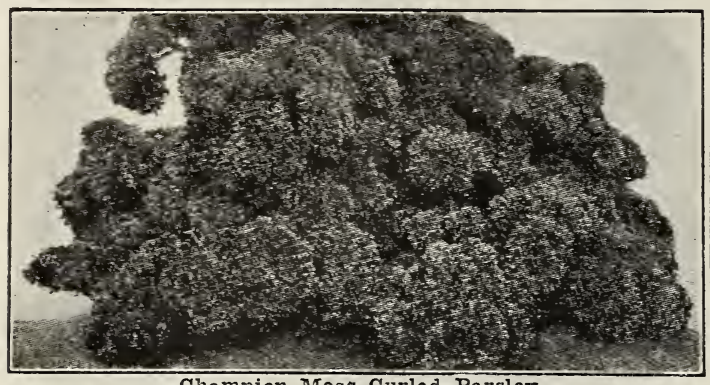

Champion Moss Curled Parsley.

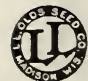

CHAMPION MOSS CURLED. A rery fine variety. The rigorous, compact plants grow rery fast, producing fresh and tender, bright green ppearance of curled moss. Besides its use as a vegetable, it is a handsome border plant and may be grown in pots or window boxes for its beautiful foliage. Pkt., 10c; oz., $15 \mathrm{c} ; 1 / 4$ lb., 35c; 1b., $\$ 1.00$, postpaid.

309. HAMBURG (Turnip Rooted). The edible ront of this variety resembles in color and shape a small parsnip. These mas be stored in the cellar for winter use. The leares are similar to plain parsley. Pkt., 10c; oz., $15 \mathrm{c}$; $1 / 4$ lb., 35c; lb., $\$ 1.00$, postpaid.

\section{PEPPER}

Sow early, in the house or in hot beds and transplant later when the ground is warm. Each packet will produce about 150 plants. An ounce, 1,500 plants.

356. †HARRIS' EARLIEST. Earliest of all. This fine new pepper is especially recommended for its earliness and also for its productiveness. It is without doubt tne earliest variety thus far introduced. Plants grow 18 inches high, bearing a load of fruit clustered all orer the plant. These are of good size and rery mild and sweet.
We highly recommend this new pepper. Pkt., 15c; oz., $85 \mathrm{c} ; 1 / 4$ lb., $\$ 2.50$; lb., $\$ 7.50$, postpaid.

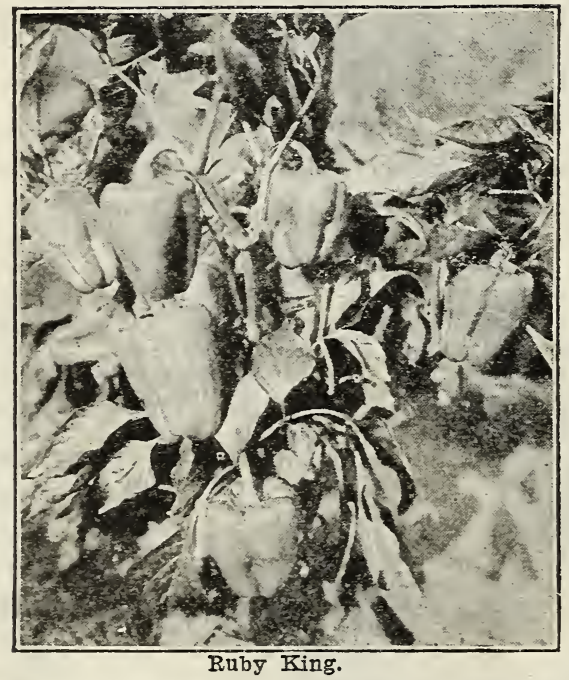

350. $\star R U B Y$ KING. One of the most popular varieties and satisfactory for both home and market garden. It grows $4 \frac{1 / 2}{2}$ to 6 inches long, and $3 \frac{1}{2}$ to 4 inches thick. The peppers are green to bright red, flesh thick, sweet and mild. Among the best for pickles. Pkt., 10c; oz., 40c; $1 / 4$ 1b., $\$ 1.30$; lb., $\$ 1.00$, postpaid.

351. BELL or BULL NOSE. A standard early-variety. Has a vigorous plant growing two feet high. The peppers are large with thick, mild, sweet flesh of excellent quality for salads or mangoes. Pkt., $10 \mathrm{c} ; 0 \mathrm{z} ., 35 \mathrm{c} ; 1 / 4 \mathrm{lb}$., $\$ 1.20$; lb., \$3.75, postpaid.

\section{PARSNIP}

Sow as early in the spring as possible, in drills 15 inches apart, covering half an inch deep. When well up, thin to 5 or 6 inches a part in the row.

Each packet contains enough seed to sow 25 feet of

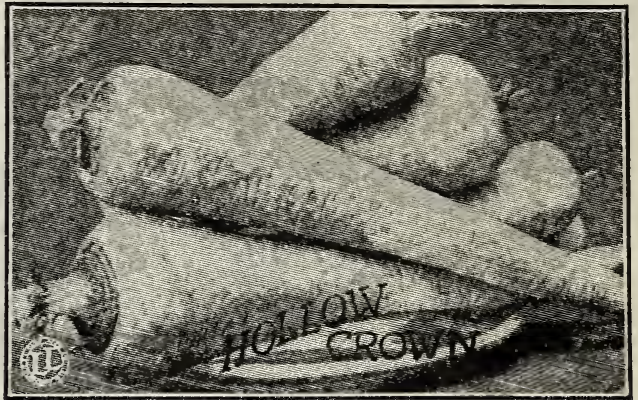

310. \#IMPROVED GUERNSEY, A much better variety than its parent, the Hollow Crown; it is more of a half-long in shape, being thicker and shorter, and more easily pulled. It is a rery heavy yielder; roots, smooth flesh, fine-grained and of excellent flavor. Pkt., 10c; oz. $15 \mathrm{c} ; 1 / 4$ lb., 30c; lb., $\$ 1.00$, postpaid.

311. HOLLOW GROWN. The old standard parsnip, long rooted, sweet flarored and desirable. Excellent, also, for stock feed. Pkt., 5c; oz., $15 \mathrm{c} ; 1 / 4$ ib., $30 \mathrm{c} ; 1 \mathrm{~b}$.,
$90 \mathrm{c}$, postpaid. drill. One ounce 200 feet of drill. Six pounds one acre. 


\section{PUMPKIN}

Our seed is from pumpkins grown for seed purposes. Each packet contains $1 / 4 \mathrm{oz}$. of seed, sufficient for 8 or 10 hills. Three to four pounds will plant an acre alone; one pound an acre with corn. Farmers should grow more pumpkins for a cheap feed.

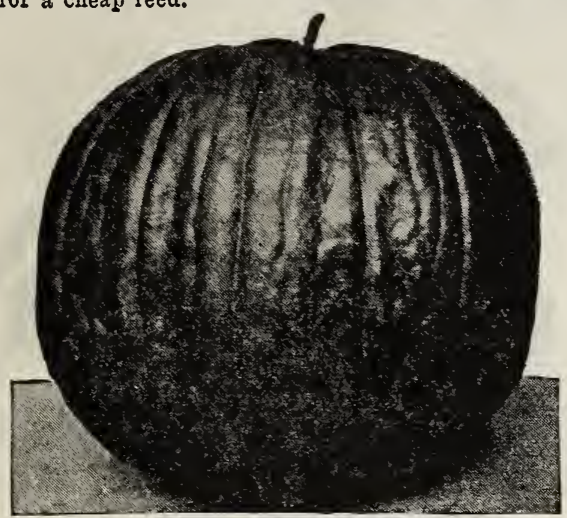

Connecticut Field Pumpkin.

362 † ARGE GONNEGTICUT YELLOW FIELD. The standard tield pumpkin. oval pumpkin. Skin reddish-orange, with rich orange-colored flesh. Extensively grown for stock feeding, and usually planted with corn. Produces enormous crops in about 65 days. Pkt., 5c; 0z., 10c; 1/4 lb., 25c; 1b., 65c; 5 lbs., $\$ 2.50$ postpaid. Not prepaid: $10 \mathrm{lbs}$. or more at $35 \mathrm{c}$.

363. SMALL SUGAR. The famous New England Pie Pumpkin. A rather small round but flattened variety, fine grained and high in sugar content. It is a good yielder, and a good keeper. Color, deep orange-yellow. Pkt., 5c; oz. $15 \mathrm{c} ; 1 / 4$ lb. 35c; lb., $\$ 1.00 ; 5$ lbs., $\$ 4.50$, postpaid.

360 . \KING OF MAMMOTHS. This variety surpasses all others in size; specimens often weighing 200 pounds; yellow flesh. It is an immense yielder, a splendid keeper and a valuable stock variety Pkt, 10c; oz., $20 \mathrm{c} ; 1 / 4 \mathrm{lb}$., $50 \mathrm{c} ; 1 \mathrm{~b}$., $\$ 1.50 ; 5 \mathrm{lbs}$., $\$ 6.00$, postpaid.

365. WHITE CUSHAW. No variety is more productive and although grown for table use mostly it is also splendid for stock feeding. It is good for any purpose for which pumpkins are used and also the long solid neck may be sliced and fried the same as beefsteak. Pkt., 10c; oz., $20 \mathrm{c} ; 1 / 4$ lb., $45 \mathrm{c}$; lb., $\$ 1.35 ; 5$ lbs., $\$ 5.75$, postpaid.

364. WINTER LUXURY, A splendid pie pumpkin, small, round, about 10 inches in diameter; skin finely netted, and a beautiful dark red color. Pkt., 5c; 0z., 15c; $1 / 4$ lb., 35c; lb., $\$ 1.00$, postpaid.

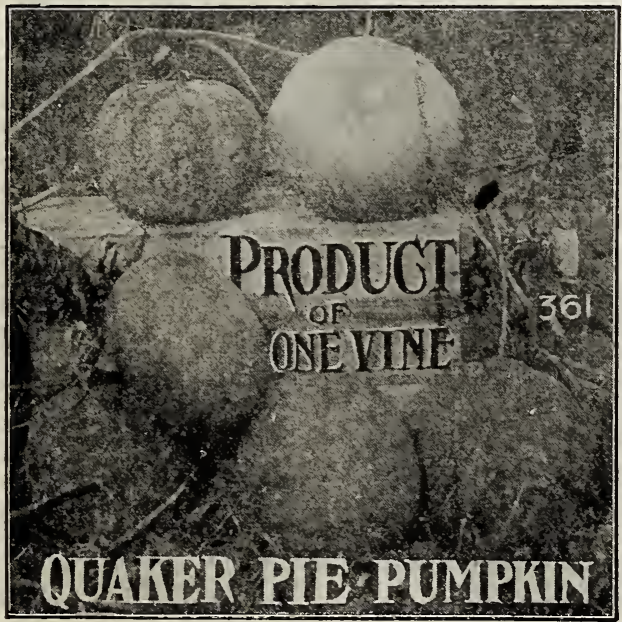

361. \QUAKER PIE. A distinct and very prolific variety, nearly round, sounewhat inclining to pear shape, and of a creamy white both inside and out: the flesh is fine grained and rich in flavor; a good keeper and among the best for pies. Pkt., 10c; 0z., 15c; $1 / 4$ lb., 40c; 1b., $\$ 1.25 ; 5$ lbs., $\$ 5.25$, postpaid.
PEANUTS

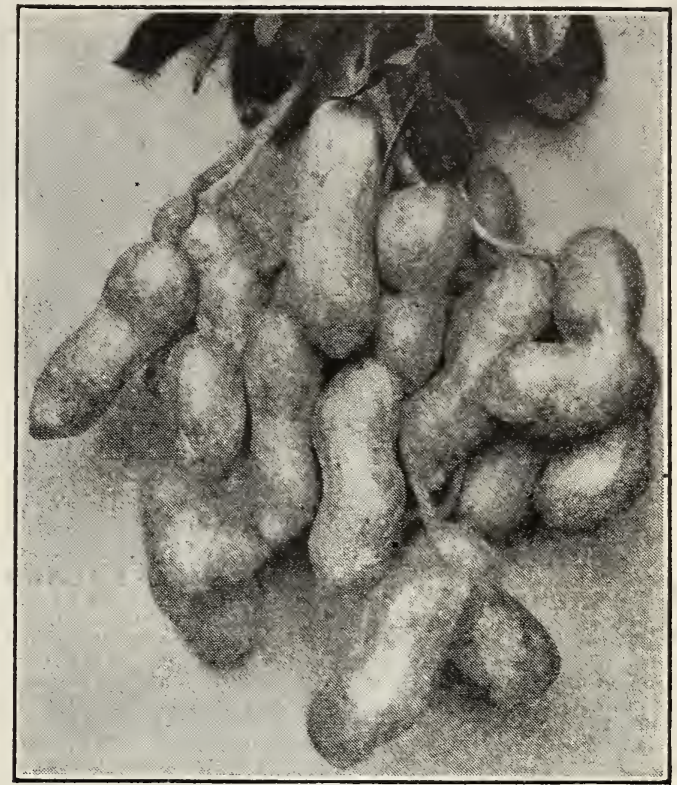

Mammoth Virginia Peanuts.

315. MAMMOTH VIRGINIA. The largest, sweetest and heaviest vielding variety. The stems are erect and so more easily cultivated than the common spreading varieties. With ordinary weather, this variety will produce a crop of good peanuts in the latitude of Wisconsin. Plant on a south slope, in sandy soil if possible. Any boy or girl can grow peanuts in the north. Large pkt., 10c; $1 / 4$ lb., $15 \mathrm{c}$; 1b., $40 \mathrm{c} ; 5$ lbs., $\$ 1.50$, postpaid.

\section{RHUBARB}

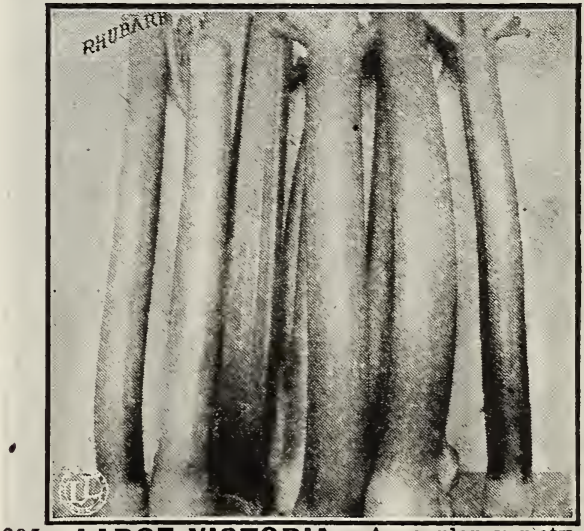

395. LARGE VIGTORIA. A popular variety. Rhubarb can be raised from seed very easily, but the stalks should not be used until the plants r.ne had a full season's growth. Pkt., 10c; oz., 15c;1,
postpaid.

\section{RHUBARB ROOTS-LAR}

After the long winter months wi fruit, early spring Rhubarb is a m sauce or pie it seems to have a mor any other fruit of the year. Rhuba We use whole roots for filling orde dug. These will give big, tender, planting. If grown on rich gror freely the first season, they shoul stalks to a plant, 15 to 20 inches Rhubarb roots as well as Aspara specialty of it. You will like 3 for $40 \mathrm{c} ; 12$ for $\$ 1.25$, postpe $\$ 1.75 ; 100$ for $\$ 6.00$. 


\section{RADISH}

Each packet contains enough seed to sow from 25 to 30 feet of drill; 10 to 12 pounds will sow one acre in drills. We especially recommend those marked with a star.
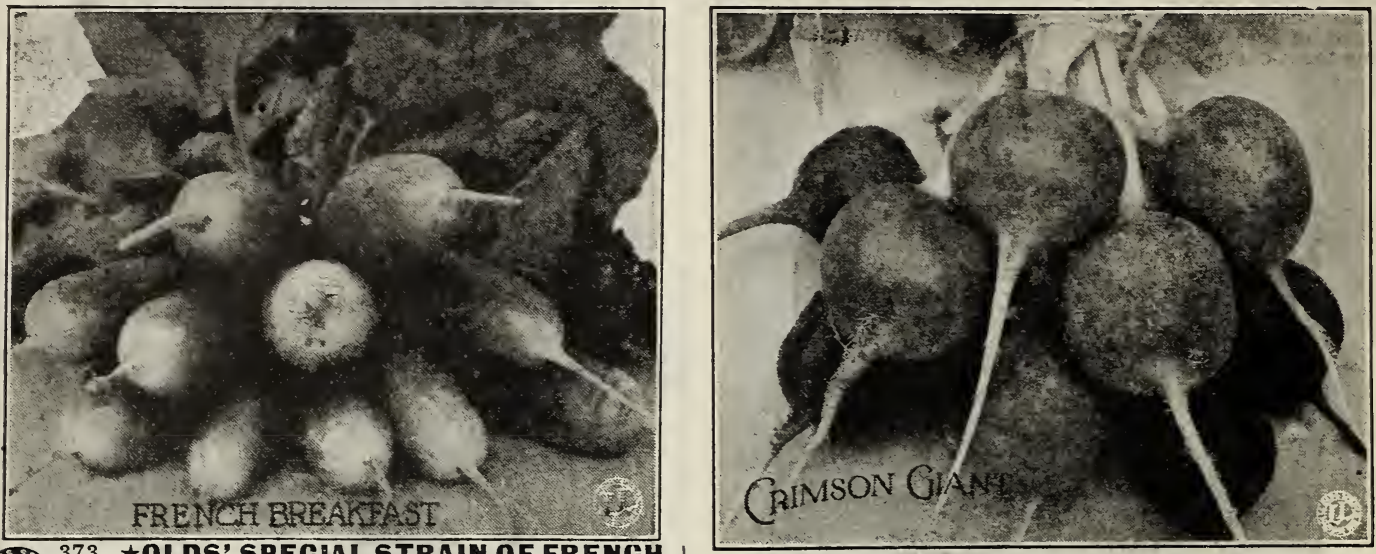

SSP. 373. *OLDS' SPEGIAL STRAIN OF FRENGH Di DREAKFAST. Our largest seller. French Break2. radish, deep scarlet in color, with a clearly defined through and about twice that in length, with very small top and tap root. It is usually ready for the table in about 25 days from sowing. Flesh, pure white and very crisp, tender, and mild. An excellent radish. Pkt., 10c; 0z., 15c; 1/4 lb., 40c; lb., \$1.25; 5 lbs., \$5.50, postpaid.

378. †OLDS' SNOWBALL. (White Box.) A medium sized, round variety, largely grown for summer use. It has a small top, skin pure white. Mild and sweet. Pkt:; $5 \mathrm{c} ;$ 0z., 15c; $1 / 4$ lb., $35 \mathrm{c}$; Ib., $\$ 1.00 ; 5 \mathrm{lbs}$., $\$ 4.50$, postpaid.

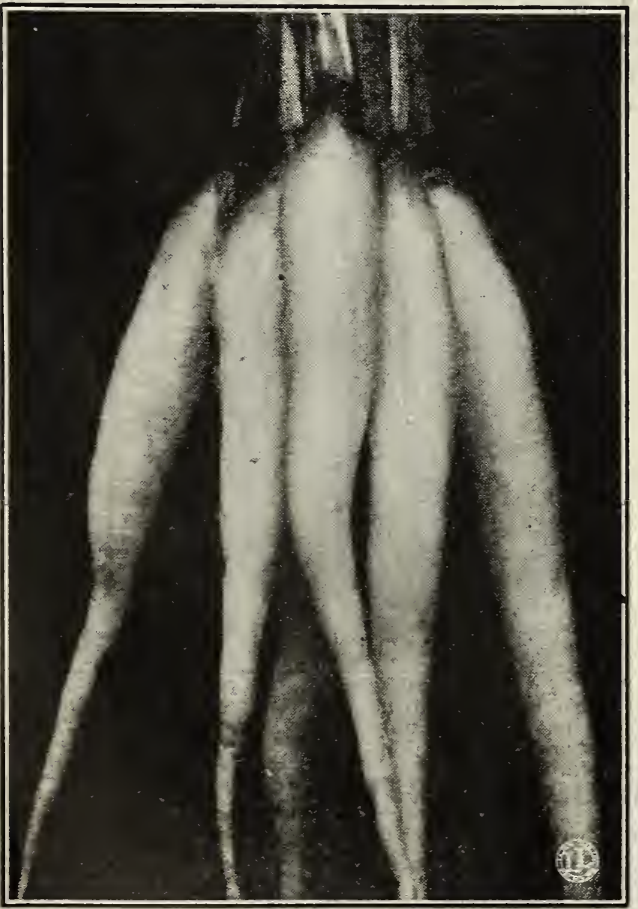

White Icicle.

.385. \WHITE IGICLE. An old American variety, and by many considered the finest of all for table use. The roots attain a length of about $51 / 2$ inches, tapering Ilgon roly from near the shoulder to the tip. It keeps in cenditifric a long time, and is crisp, mild and sweet. Color

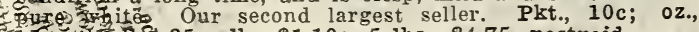
1.5.

376. †CRIMSON GIANT. This is a new extra large radish, often growing to double the size of the other early turnip-shaped varienes, while retaining its firmness and crispness longer than other earlies. It is quick growing, suitable for both forcing and out-door growing, developing roots of a handsome deep crimson, which vary in shape from round to oval. Flesh, pure white; flavor, mild. We highly recommend this radish. Pkt., 10c; 0z., 15c; $1 / 4$ lb., 40c; lb., $\$ 1.15 ; 5$ lbs., $\$ 5.00$, postpaid.

371. †OLDS' EARLY SGARLET TURNIP. Scarlet Turnip is a splendid, early round, bright-red turnipshaped radish; flesh white, crisp and tender. A great farorite both with market gardeners and home gardeners. It grows quickly and is one of the most popular of all radishes. One of our largest sellers. Pkt., 5c; 0z., 15c; $1 / 4$ lb., 35c; lb., 90c; 5 lbs., $\$ 4.00$, postpaid.

3781/2. OLDS' EARLIEST WHITE FORGING. A selected strain, especially adapted to forcing in the greenhouse or hot bed but may be nsed out of doors with excellent results. The flesh is white, crisp and tender. Pure white, olive shaped. Pkt., 5c; oz., 10c; 1/4 lb., 30c; lb., 90c; 5 Ibs., $\$ 4.00$, postpaid.

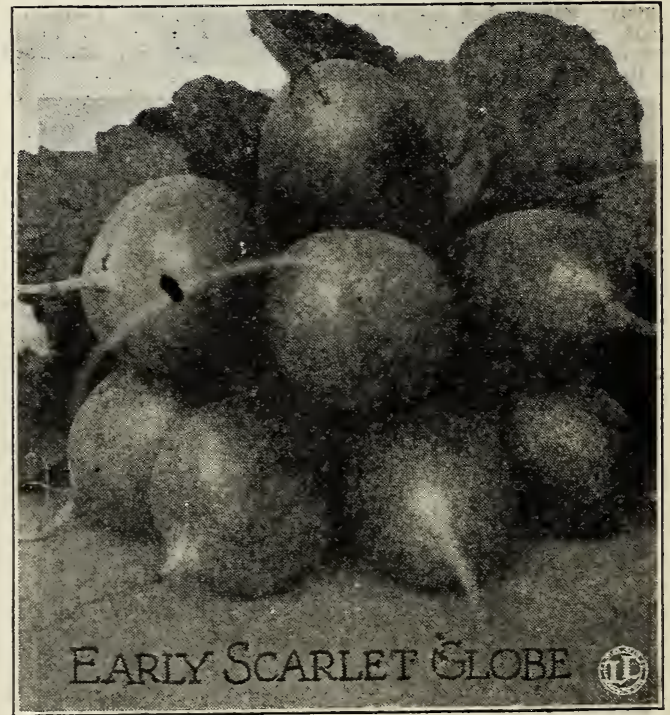

377. EARLY SGARLET GLOBE. (Vick's.) One of the best all around radishes for early outdoor sowing. The skin is a bright scarlet; flesh, pure white, crisp, tender and of delicious quality. A very fine variety. Pkt., 10c; oz., 15c; $1 / 4$ lb., $35 \mathrm{c}$; lb., $\$ 1.10 ; 5$ lbs., $\$ 4.75$, postpaid. 


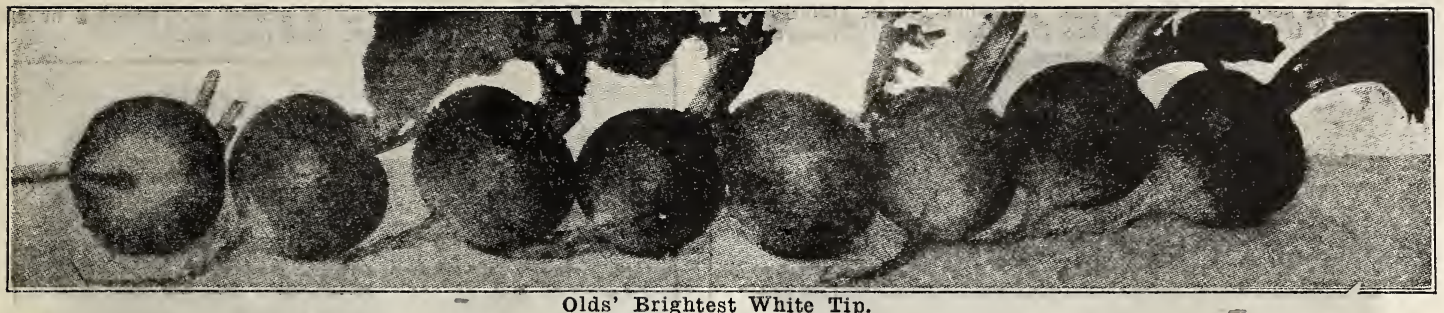

OID, BRITHST WHITE TIP (Sparkler.

A splendid selection of the Early Scarlet fI Turnip White Tipped Radish, but showing more white, practically the whole lower half being pure white, and sweetness, make it equaliy pleasing to the taste. Pkt., 10c; oz., 15c; $1 / 41 \mathrm{~b}$., $40 \mathrm{c} ; 1 \mathrm{~b}$., $\$ 1.15 ; 51 \mathrm{bs}$., $\$ 5.00$, postpaid.

381. WHITE STRASBURG. A good second early, large radish and also suitable for late planting. Skin and flesh both pure white. After reaching its full size, which is about $51 / 2$ inches long and $11 / 2$ inches in diameter, it will stay in condition nearly two weeks before becoming pithy. Pkt., 5c; oz., 10c; 1/4 lb., 30c; lb., 90c; 5 lbs., $\$ 4.00$, postpaid.

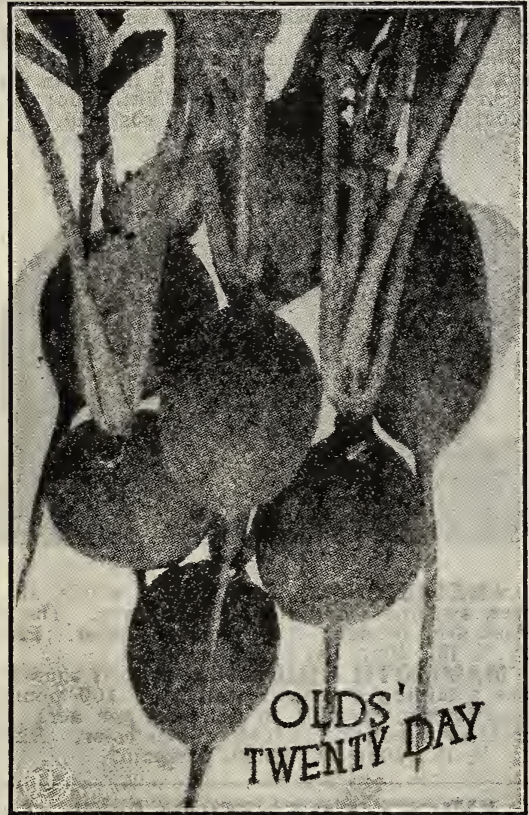

384. GINCINNATI MARKET. An improved strain of Long Scarlet. The tops are very small, so that they may be grown close together. It is a long red radish, growin straight and smooth, with crisp, mild flesh and pleasant flavor. One of the very best market varieties. Pkt., 5c; oz., 10c; $1 / 4$ lb., $30 \mathrm{c}$; $1 \mathrm{~b} ., 90 \mathrm{c} ; 5$ lbs., $\$ 4.00$, postpaid.
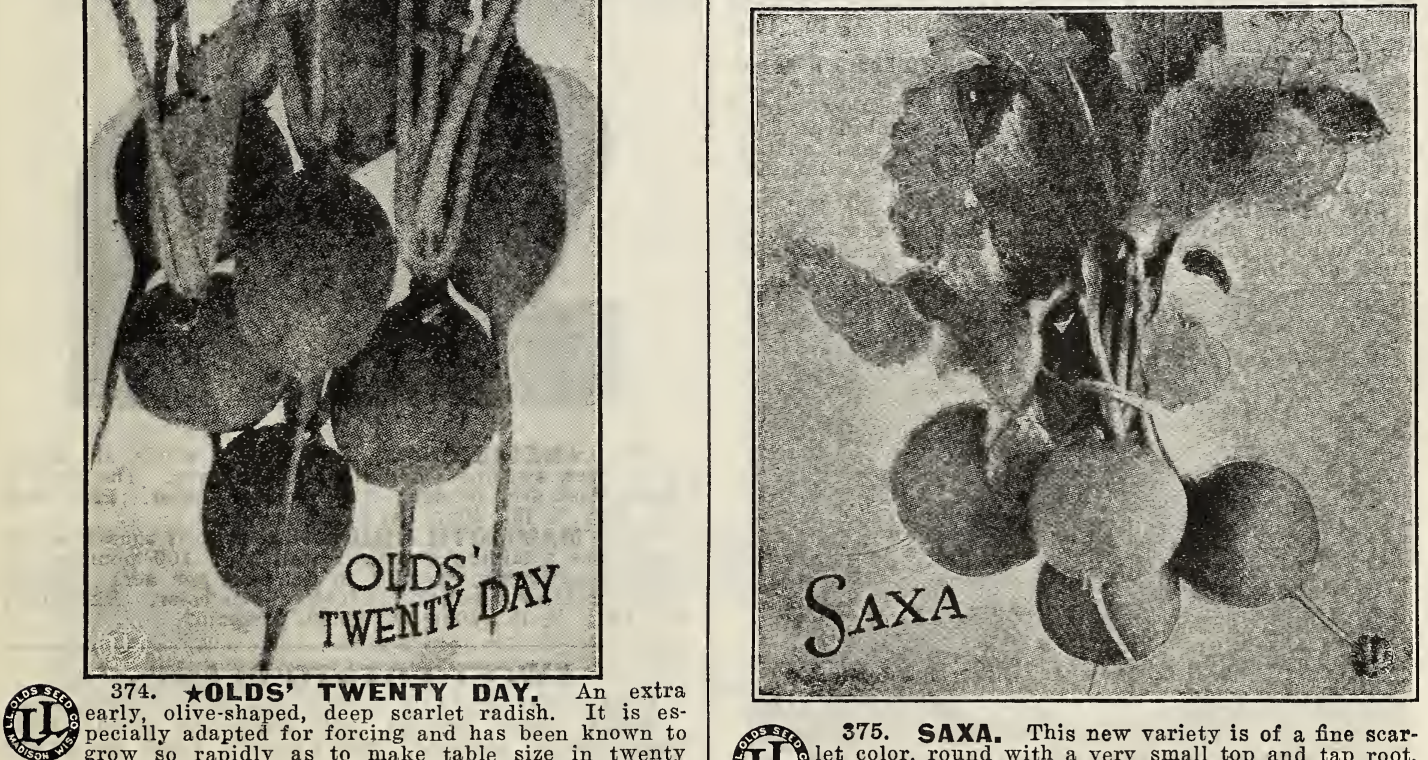

374. †OLDS' TWENTY DAY, An extra grow so rapidly as to make table size in twenty days from planting. It is also an excellent garden variety, flesh crisp and mild, attractive in appearance, and, we believe, the earliest of all radishes. Pkt., 10c; oz., 15c; $1 / 4$ lb., $40 \mathrm{c}$; lb., $\$ 1.25$; 5 lbs., $\$ 5.50$, postpaid.

\section{WINTER RADISHES.}

390. NEW WHITE GHINESE. (New Celestial). A large, half-long radish, which will keep in fine condition a long time. White and brittle. Excellent for market gardeners' use, on account of large size and handsome appearance. Can be sown any time from July 1 st to August 15th. Pkt., 10c; 0z., 15c; $1 / 4$ 1b., 35c; 1b., $\$ 1.00$; 5 lbs. $\$ 4.50$, postpaid.

391. CHINA ROSE WINTER. Handsome, long, rose-colored, mild, sweet flavored, and of crisp, brittle texture. It is smooth and cylindrical in shape, and keeps well through fall and winter. Pkt, 5c; 0z., 10c; $1 / 4$ lb, $30 \mathrm{c}$; lb., 90c; 5 lbs., $\$ 4.00$, postpaid.

392. LONG BLAGK SPANISH. One of the oldest but one of the best. The skin is black, and the flesh white and firm. Grows 8 or 9 inches long and 2 to 3 inches in diameter and thus is a great yielder. Pkt., 5c; oz., 10c; 1/4 lb., 30c; lb., 90c; 5 lbs., $\$ 4.00$, postpaid.

MARKET GARDENERS' PRIGE LIST

If you are a Market Gardener ask for our "Wholesale Market Gardeners' Price List."

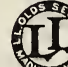

375. SAXA. This new variety is of a fine scarlet color, round with a very small top and tap root. It is very early, and has been placed on the dining table in three weeks from the time the seed was sown. Very crisp, juicy and mild. It may be sown as early in the spring as the garden can be worked, and is adapted to greenhouse culture. Some say it is the earliest of all forcing varieties. Pkt., 10c; 0z., $15 \mathrm{c}$; $1 / 4 \mathrm{lb}$., $40 \mathrm{c}$; lb., $\$ 1.25$; 5 lbs., $\$ 5.50$, postpaid.

394. OLDS" MIXED RADISH. An assortment of radishes may be easily grown together with pleasing results, affording the diner his choice of an interesting $v a$ riety at the table. $\mathrm{He}$ may choose long, olive or turnipshaped, in white, red or rose. This mixture will furnish good radishes for a long season with only one plantint. Pkt., 5c; 0z., 10c; $1 / 4$ 1b., 25c; 1b., 75c; 5 1bs., $\$ 3.50$, postpaid.

\section{REGARDING WINTER RADISHES}

There is an evident misunderstanding in regard to winter radishes which we would like to correct. Many people insist on planting winter radishes in the spring the same as other radishes. This will not do. They should not be planted until July or if the weather is very dry better wait until August. Winter radishes are good to eat as soon as they are large enough. The flavor is as good or better than spring radishes and they are much larger in size. For winter use, dig them and pack them in earth the same as parsnips, salsify, or celery. 


\section{SQUASH}

The seed we offer is from squashes grown strictly for seed and is all high grade seed. A packet will plant 8 or 10 hills; 3 to 4 pounds an acre in hills. Use "Evergreen"

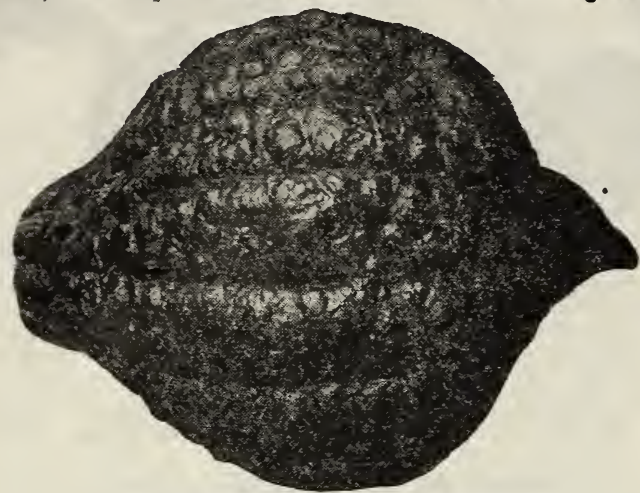

A Typical Specimen of a True Hubbard.

411. \TRUE HUBBARD. Considered the best of the winter squashes and more largely grown for market and general use than any other variety. A large oliveshaped squash with dark green skin; thick, fine grained flesh of good flavor and of orange-yellow color A good keeper. Yields heavily. Pkt., 10c; oz., 15c; 1/4 1b., 40c; 1b., $\$ 1.25$; 5 lbs., $\$ 5.50$, postpaid.

413. GOLDEN HỦBBRD. (Red Hubbard.) Identical in form and fruitfulness with True Hubbard, but somewhat smaller and earlier. The moderately wartes skin is a beautiful salmon-red color. Like the True Hubbard the flesh is thick, fine grained and of good quality. It also is a good keeper. Pkt., $10 \mathrm{c}$; oz., $15 \mathrm{c} ; 1 / 4$ 1b., $40 \mathrm{c}$; lb., $\$ 1.25 ; 5$ lbs., $\$ 5.50$, postpaid.

418. BLUE HUBBARD. A new type of Hubbard similar to the original except that it is blue grey in color. Said to be superior to all other Hubbards in quality. Pkt., $10 \mathrm{c}$; Oz., $15 \mathrm{c}$; $1 / 4$ 1b., $45 \mathrm{c}$; 1b., $\$ 1.35$, postpaid.

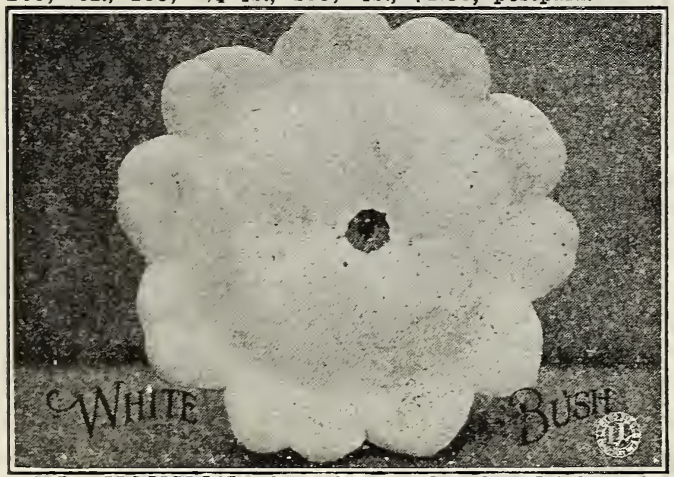

405. MAMmOTH WHITE BUSH SGALLOP. Patty Pan. An early maturing summer variety which will hear throughout the season if kept gathered. Squashes white and good sized. flesh thick of fine quality. Pkt. $5 \mathrm{c} ;$ oz., 15c; $1 / 4$ lb., 35c; 1b., $\$ 1.00 ; 5$ lbs., $\$ 4.50$, postpaid.

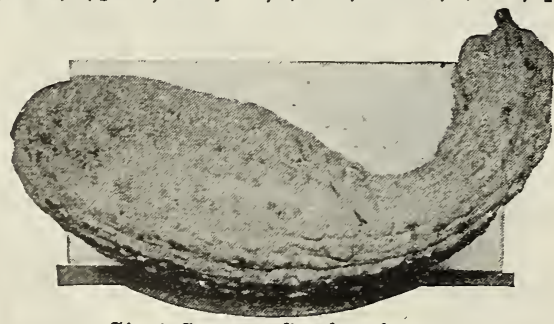

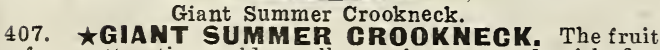
is of an attractive golden-yellow color, covered with fine warts. Grows 15 to 20 inches long. The few seeds are all in the blossom end. Very prolific of good quality, and the most popular of the summer varieties. Pkt., 10c; oz., $15 \mathrm{c}$; $1 / 4$ lb., $40 \mathrm{c}$; 1b., $\$ 1.25 ; 5$ lbs., $\$ 5.50$, postpaid. or "Sure Noxem" for the bugs. See page 93 .

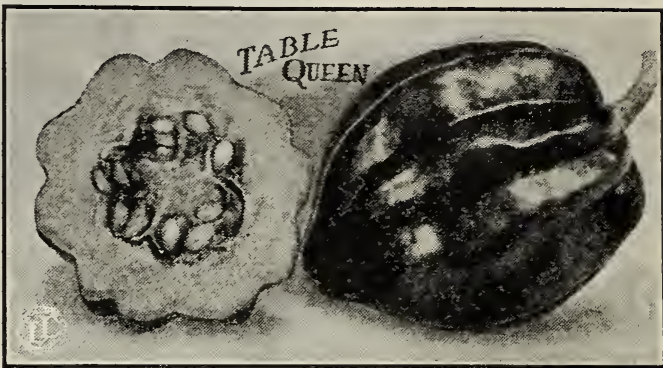

409. tOLDS' TABLE QUEEN. This unique winter squash has already won favor second only to Hubbard and in some particulars is preferred to that excellent variety. Equal to the Hubbard in flavor, dryness and keeping quai ities and just the right size to cut in half, (when it will bake in 20 minutes) and serre indiridually in the half shell. The shell is hard, smooth and ridged; of a uniform dark green color, averaging 6 to 8 inches in diameter Vines vigorous and very productive. Pkt., 10c; oz., 20c; $1 / 4$ lb., 60c; 1b., $\$ 1.65$; 5 lbs., $\$ 7.50$, postpaid.

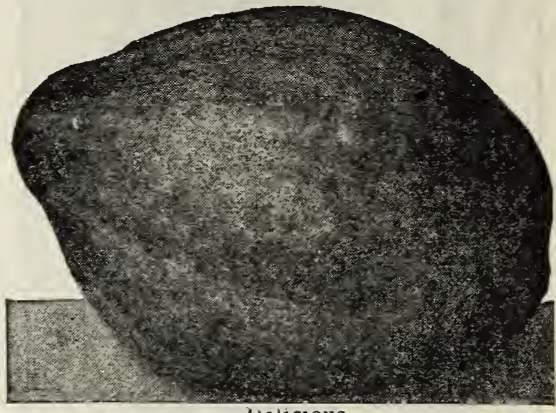

Velicious.

410. \DELIGIOUS. This variety rirals all others in dryness, sweetness and richness of flavor. The shell is green, flesh deep orange. An excellent keeper. Pkt., 10c 0z., 15c; 1/4 1b., 40c; 1b., $\$ 1.25$, postpaid.

420. MAMMOTH GHILI. The largest squash of all sometimes attaining a weight well over 100 pounds. It yields enormously, from 8 to 15 tons per acre: widely used for stock feeding. Bright orange color. Pkt., 10c; 0z., 15c; 1/4 1b., 40c; lb., \$1.25, postpaid:

\section{SWEET POTATO PLANTS.}

Ready about May 15th or later according to the weather.

Prices, either variety: 100 plants for $\$ 1.50 ; 1.000$ plants, $\$ 8.50$, postpaid. Not prepaid: 1,000 for $\$ 7.00$ 5,000 for $\$ 30.00$.

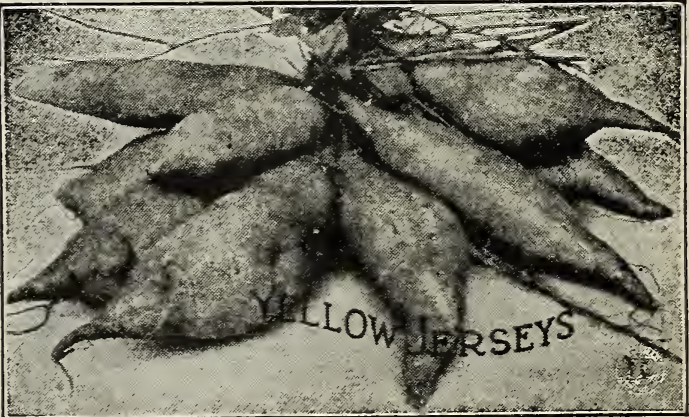

YELLOW JERSEY. A standard well known variety. . The yield will please you.

NAÑCY HALL. Nancy Hall is really a small Southern yam. It is now a very important commercial variety. 
Spinach is a very important market crop, and large quantities of seed are used every year. Our seed is new crop and as low in price as first quality seed can be sold for. Our packets each contain seed sufficient for 12 to 15 feet of drill; 10 to 12 pounds will sow an acre in drills.

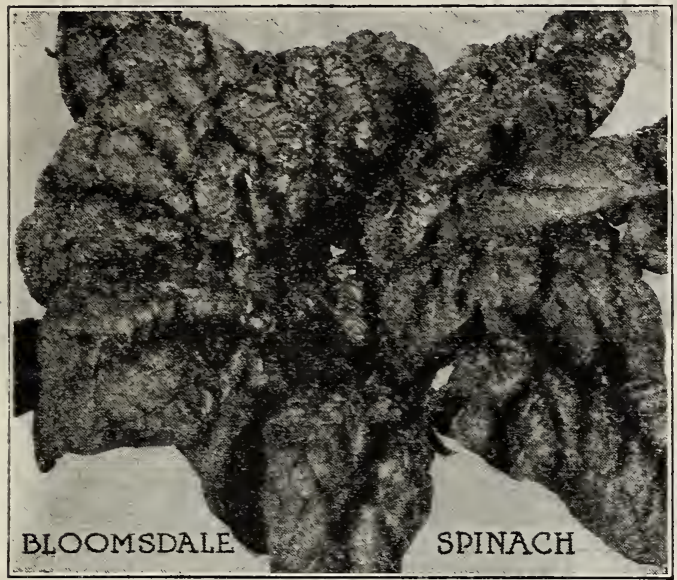

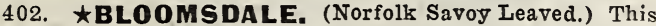
is a very early variety and one of the best to plant in the autumn for early spring use. One of the best for market and canning. The plant is of upright growth, with thick, glossy, dark green leaves of medium size, pointed but broad, and crumpled like those of Saroy cabbage. Stems three inches long. It is very hardy, but seeds quickly in warm weather. Suitable for home gardens but grown more largely by market gardeners. A widely used variety. Pkt., 10c; 0z., 15c; 1/4 lb., 25c; 1b., 50c; 5 lbs., $\$ 2.00$, postpaid.

400. VICTORIA. This is one of the best known varieties. The foliage is heavy, the broad, dark green leaves being slightly crumpled, rather pointed, and of the finest quality. It is grown extensively both by home gardeners and market growers for spring, early summer and fall use.. Stands hot weather well and is exceedingly slow to shoot to seed. Pkt., 5c; 0z., 10c; 1/4 1b., 20c; 1b. $45 \mathrm{c} ; 5$ lbs., $\$ 1.75$, postpaid.

\section{SALSIFY OR VEGETABLE OYSTER}

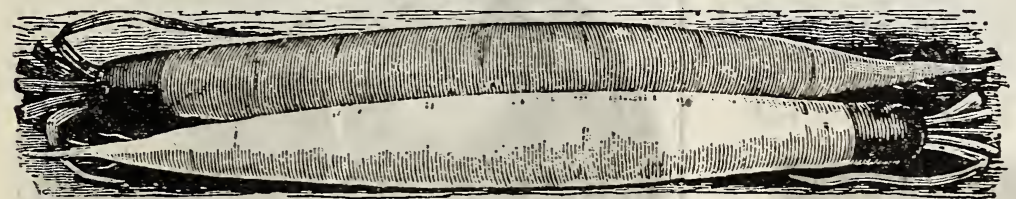

Mammoth Sandwich Island Salsify.

Culture. Drill the seed in rows, 20 inches apart or whatever distance apart fits your method of cultivation. Plant as early in the spring as the ground will do to work and cover with about an inch of soil: sandy loam, rich in humus is best. A packet of seed will plant about 12 to 15 feet of row. Thin the plants to about 4 or 5 inches apart. Salsify may be left in the ground all winter, the same as parsnips, but is better when packed in earth and stored in a cool basement; or you can pack the roots in a barrel without soil, sink the barrel in the ground, cover to exclude the air and let it freeze. You can get the roots any time you want them during the winter by employing this method, but they must be covered when frozen so that they will remain frozen.

Recipe for use: Scrape the roots clean, cut in slices and boil in water. When cooked soft, (do not drain) add milk and flavoring, the same as for oysters. Salsify has a decided oyster flavor and is something really good; easy to grow and easy to prepare.

397. MAMMOTH SANDWICH ISLAND. This is the best variety of Salsify, in fact the only one worth considering. The roots are usually long, smooth and straight Pkt., 10c; oz., 25c; $1 / 4$ lb., $75 \mathrm{c}$; 1b., $\$ 2.25$, postpaid.

If you are a Market Gardener, ask for our 'Market Gardeners' Wholesale Price List.',

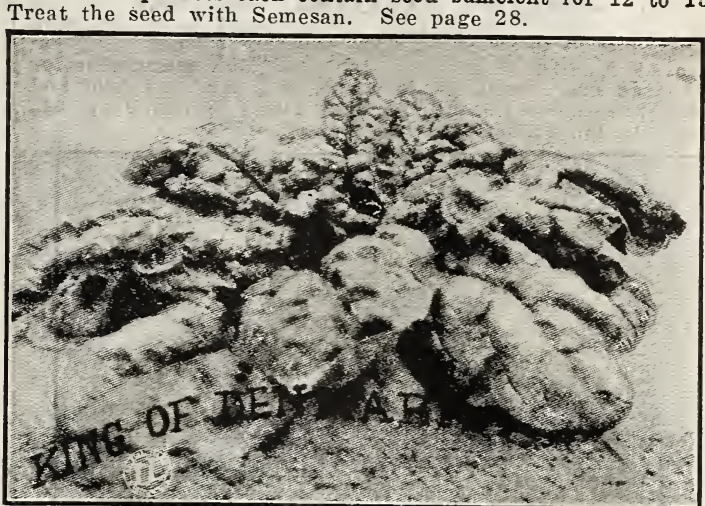

$401 \frac{1}{2}$. \KING OF DENMARK. A new spinach and $\mathbf{a}$ very valuable introduction. The plants are ready for use as soon as the early kinds and remain in good condition two weeks after other varieties hare gone to son in type but leaves are more crumpled and are darker green in color, thick, of good quality. Stands well after cutting. We believe this variety will, in a few rears, become the leader. Equally valuable for both the home and market gardener. Pkt., 10c; oz., 15c; $1 / 4$ lb., 30c; 1b., 75c; 5 lbs., $\$ 2.75$, postpaid.

403. *OLDS' LONG SEASON. (Triumph.)
About the best long season spinach. The plant
makes a flat rosette of very dark green, broad,
crumpled, tender leaves. Remains in good condi. tion through hot summer weather and stands an exceptionally long time without running to seed; one of the oz., 15c; 1/4 1b., 30c; 1b., 75c; 5 lbs., \$3.00, postpaid.

4031/2. NEW ZEALAND. Entirely distinct from true spinach in type. Thrives in hot weather and in any soil, rich or poor. The stems and leaves are soft, thick fleshy and crystalline in appearance; plant, tall and spreading, with numerous side shoots; leaves rather
small and pointed. Pkt., 10c; oz., 20c; 1/4 1b., 35c; lb.,

$\$ 1.00 ; 5 \cdot 1 \mathrm{bs} ., \$ 4.50$, postpaid.

\section{TOBACCO}

500 tC 0 M S T O K SPANISH. The oldest and best knon tobaceo in Wisconsin. T. Pomeroy, well known grower, dealer and authority on Wisconsin leaf tobacco. We be lieve that this in itself assures the purity of our strain. its vigor of growth; its broad heary leaves with rounded tips, its large yield and its agreeable blending of flavor with the filler. Our seed was cleaned and tested at the Wisconsin Experiment Station. This tobaceo has been endorsed by 65 leading tobacco packers, by the officials of the Wisconsin Tobaceo Pool, and by the Wisconsin Ex $25 \mathrm{c}$ : $0 \mathrm{z}, 75 \mathrm{c}$; $1 /$ lb $\$ 2.75$, postpaid.

503 . * $\star$ WISCONSIN GONNEGTICUT HAVANA

\section{No. 38.}

Wisconsin College of Agriculture in selecting and experi menting with the varieties of Wisconsin tobacco, have resulted in the derelopment of wisuced by careful breed ing and selection. This variety has the endorsement of the Wisconsin Tobace Pool.

Our seed bed was disinfected before planting; growing crop was visited, inspected and $0 . \mathrm{K}^{\prime} \mathrm{d}$ by Professor Johnson; the seed was finally cleaned and tested at the Experiment Station. Every possible precaution has $25 \mathrm{c}$; 0z., $\$ 1.00$; 1/4 1b., $\$ 3.50$, postpaid.

\section{USE COMMERCIAL FERTILIZER FOR YOUR TOBACCO.}

We recommend 2-12-6, "Tobacco and Beet Grower" for tobacco. We handle Swift's Red Steer Brand. See page 92. Special prices in quantity. 


\section{TOMATO}

Our seed is from tomatoes grown for seed. One packet will produce 300 plants. Three ounces will plant an acre. 425. „SPARK'S EARLIANA. Best early. No variety of recent introduction has attracted more attention than this. Early tomatoes are usually of small size, but Spark's Earliana is not only very early, but remarkable for its large size. Handsome in shape, of a dark red color and very firm-deep red flesh. Pkt., 10c; $1 / 2$ oz., 25c; 0z., $40 \mathrm{c} ; 1 / 1$ lb., $\$ 1.25 ;$ lb., $\$ 3.75$, postpaid.
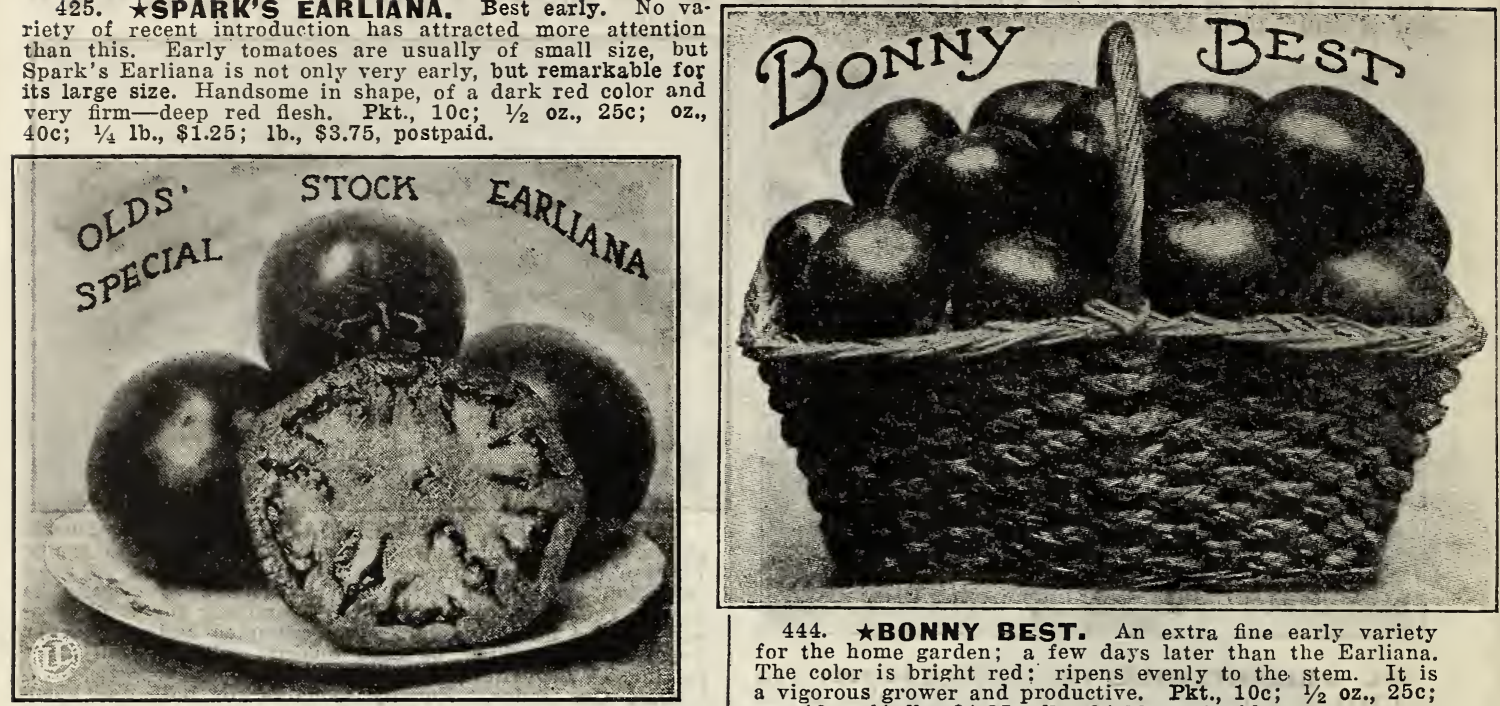

444. $\star B O N N Y$ BEST. An extra fine early variety for the home garden; a few days later than the Earliana. The color is bright red : ripens evenly to the stem. It is a vigorous grower and productive. Pkt., 10c; 1/2 0z., 25c; oz., $40 \mathrm{c}$; $1 / 4$ lb., $\$ 1.25$; lb., $\$ 4.00$, postpaid.

426. *SUGGESS. Just right for a second early; bright red, of fine flavor and handsome in appearance. Pkt., 5c; oz., 25c; 1/4 1b., 85c; lb., \$2.75, postpaid. 439. OLDS' GOLDEN BEAUTY. (Golden Q Queen). A large, smooth, pure yellow tomato. or preserving. Pkt., 10c; $1 / 2$ oz., 25c; oz., $45 \mathrm{c}$; $1 / 4$ lb., $\$ 1.50 ;$ lb., $\$ 5.00$, postpaid.

433. $\star N E W$ MARGLOBE. A new variety that is attracting a lot of attention. Resists nail-head rust and fusarium wilt. Has proven successful under the most severe tests. Pure scarlet in color, globular in shape, extra large, smooth, early, beautiful in appearance and very productive. Above all, the quality is most excellent. Pkt. $15 \mathrm{c}$; $1 / 2$ oz., $40 \mathrm{c}$; 0z., $75 \mathrm{c}$; 1/4. 1b., $\$ 2.25$; 1b., $\$ 6.50$, postpaid.

428. FORDHOOK FIRST. A perfectly smooth, solid tomato of first class appearance, maturing very early. The introducer, Burpee, says of it: "We consider it the most outstanding early pink-fruited tomato in existence: The fruits grow to a good size and are borne most prolifically all over the vines." Pkt. 5c; 1/2 0z.,. 15c; oz., 25c; 1/4 lb., 85c; lb., $\$ 3.00$, postpaid.

432. DWARF CHAMPION. A very popular dwarf variety; desirable where space is limited; fruit is smooth, solid and medium in size; color pink. Pkt., $10 \mathrm{c} ; 1 / 2$ oz., $25 \mathrm{c}$; oz., $40 \mathrm{c}$; $1 / 4$ lb., $\$ 1.25$; lb., $\$ 4.50$, postpaid.

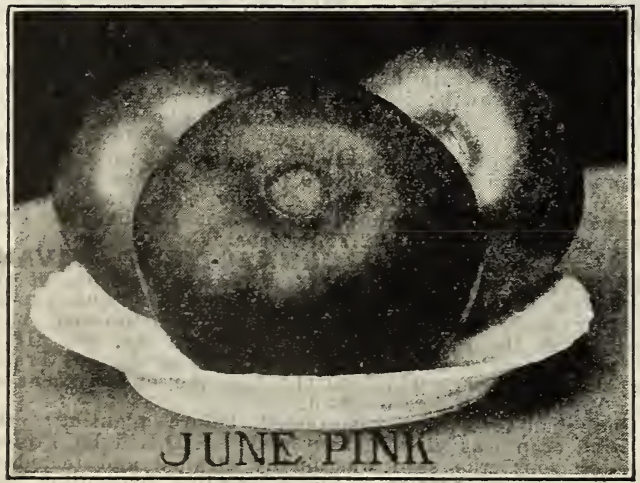

443. „JUNE PINK. The earliest of all pink tomatoes. A good yielder, of high quality, running very smooth for an early sort; similar in habit and shape to the Earliana, differing from it in color only. The June Pink while primarily an early tomato continues to bear and ripen fruit up to frost. Pkt., 10c; $1 / 2$ oz., 25c; oz., $45 \mathrm{c}$; $1 / 4$ lb., $\$ 1.35$; 1b., $\$ 4.50$, postpaid.

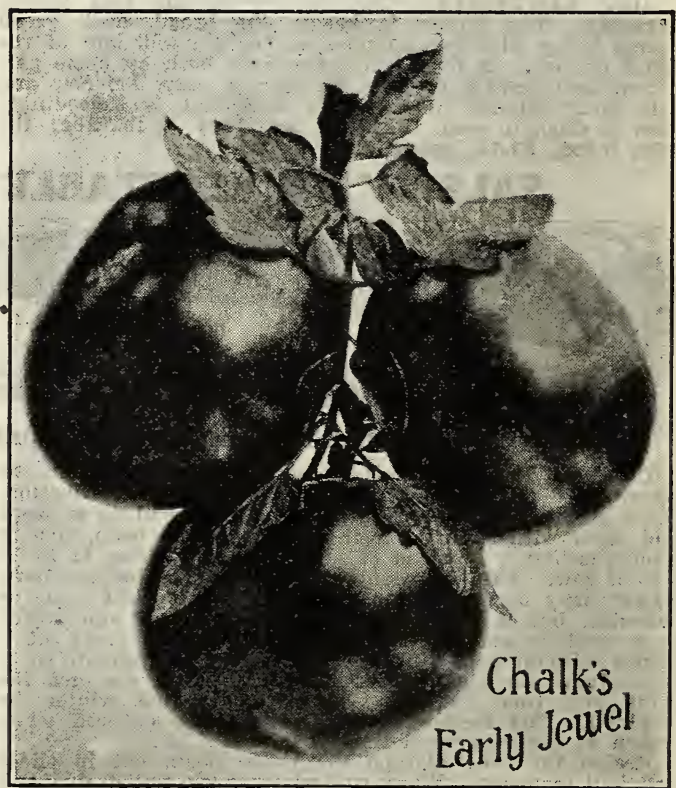

434. ऋGHALK'S EARLY JEWEL. An exception ally fine early variety, only a few days later than Earliana. Large handsome fruit, smooth, round and solid, with comparatively few seeds, and sweet flavor. Pkt., 10c; $1 / 2$ oz., $20 \mathrm{c}$; oz., $35 \mathrm{c}$; $1 / 4$ lb., $\$ 1.00$; lb., $\$ 3.50$, postpaid.

TREAT TOMATO SEED WITH SEMESAN,

Commercial field tests near Wilmington, Del., have shown a 25 per cent increase in yield from treated seed over untreated. See page 28. 


\section{TOMATO}

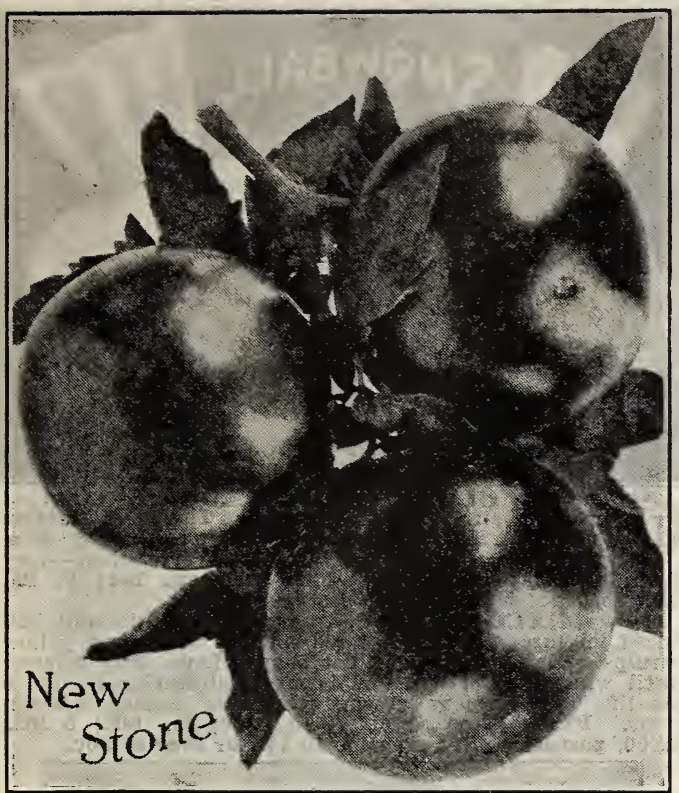

427. $\star N E W$ STONE. The standard main crop variety; always dependable, very vigorous and productive. The fruit is round, large, solid, smooth and deep red in color. Our seed is from selected stock, Pkt., 10c; $1 / 2$ oz. $20 \mathrm{c}$; 0z., 30c; $1 / 4 \mathrm{lb}$., 90c; 1b., $\$ 3.00$, postpaid.

430. 'DWARF STONE. One of the best of the dwarf varieties. Fruit large, smooth, solid and deep scarlet. A desirable home garden variety. Pkt., 10c; 1/2 0z., 25c oz. $40 \mathrm{c} ; 1 / 4$ lb., $\$ 1.25 ;$ lb., $\$ 4.50$, postpaid.

429. † MATCHLESS. A great main-crop tomato of large size and perfectly smooth. Fruit, a handsome cardinal red, firm and solid. Pkt., $5 \mathrm{c} ; 1 / 2$ oz., 15c; oz., $25 \mathrm{c}$; $1 / 4$ lb., 80c; lb., $\$ 2.85$, postpaid.

438. TENORMOUS. Also called Beefsteak and Crimson Cushion. Really a red Ponderosa and the largest of all red tomatoes. A mid-season, main crop variety, very large, very smooth, with solid meat and few seed cells and seeds. The vines are large, strong and vigorous, bearing many "Enormous" bright red fruits of good flavor. Pkt., $10 \mathrm{c}$; $1 / 2$ oz., $25 \mathrm{c}$; oz., $40 \mathrm{c}$; $1 / 4$ lb., $\$ 1.25$; 1b., $\$ 4.00$, postpaid.

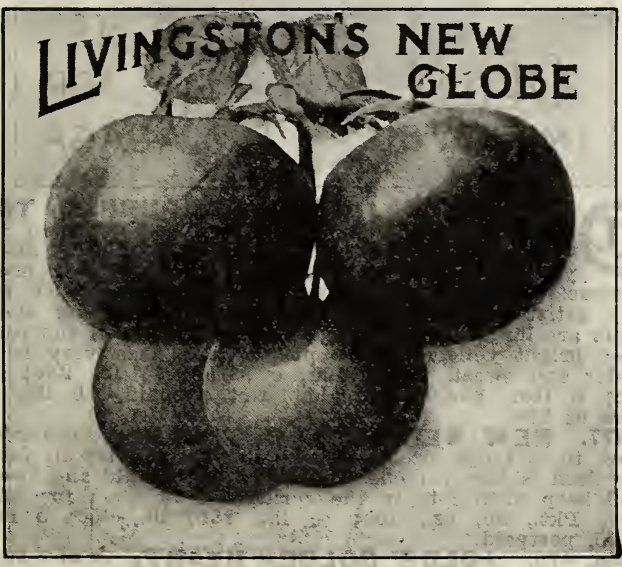

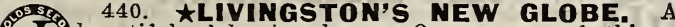
T beautiful globe in shape. On account of this greater number of slices can be taken from each tomato. It ripens with the second earlies. Pkt., paid.

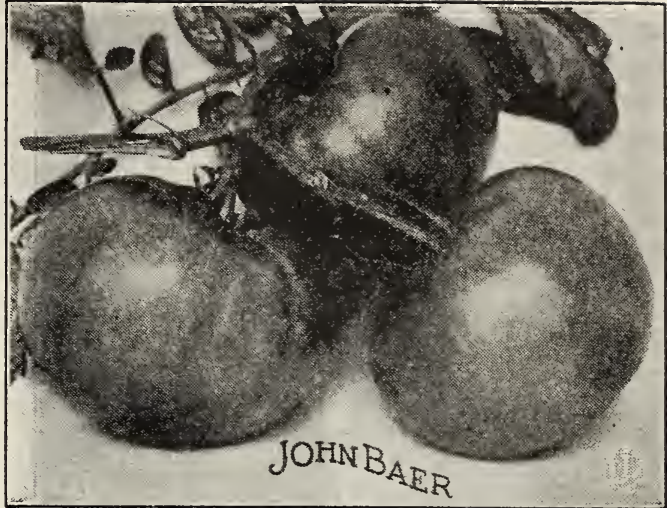

4361/2. \JOHN BAER. A new variety of merit. A few days later than Earliana, but produces a heavier crop. Tomatoes large; bright red in color. Pkt., 10c; $1 / 2$ oz., $25 \mathrm{c}$; oz., $40 \mathrm{c}$; $1 / 4$ lb., $\$ 1.25$; lb., $\$ 4.00$, postpaid.

431. TRUCKERS" FAVORITE. A good main-erop variety of the same season as Matchless and equally as productive. Fruits large, purple, regular in size and form, thick meated and solid. Pkt., 5c; $1 / 2$ oz., 20c; oz., 30c; 1/4 1b., 95c; 1b., $\$ 3.00$, postpaid.

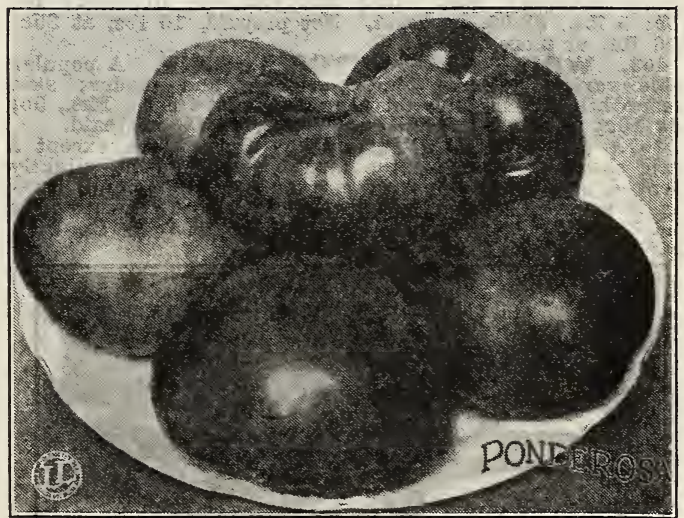

437. PONDEROSA. The Giant Tomato. The tomatoes grow in beautiful clusters, mostly oblong in shape, with solid flesh. Color deep purple. Pkt., 10c; 1/2 0z. $30 \mathrm{c}$; oz., 50c; 1/4 lb., $\$ 1.75$; lb., $\$ 6.00$, postpaid.

\section{SMALL FRUITED TOMATOES.}

Prices, all varieties: Pkt., 10c; $1 / 2$ oz., 30c; oz., 50c; $1 / 4$ 1b., $\$ 1.50 ; 1 b ., \$ 5.00$.

455. GROUND GHERRY Or HUSK TOMATO. The small yellow fruit has a flavor all of its own. The fruit is protected by the loose fitting outer husk.

446. YELLOW PEAR. Fruit a bright handsome yellow. Usually grown for preserves and "tomato figs:"

447. YELLOW PLUM. Perhaps even more popular for preserves than Yellow Pear. Grows in clusters.

449. RED CURRANT. Smaller than Yellow Cherry and red in color. Used for pickles, preserves, etc.

\section{HOME GROWN TOMATO PLANTS.}

\section{Ready about May 10th.}

These plants are hotbed grown and transplanted, and hardened, the very best plants that can be produeed. We will have the following varieties only: Earliana, Chalk's Early Jewel, Dwarf Stone and Ponderosa.

Prices postpaid: 12 for $35 c ; 50$ for $\$ 1.25 ; 100$ for $\$ 2.25$.

"GROWING AND FERTILIZING TOMATOES."

12 page booklet of valuable information and suggestions free for the asking. 


\section{TURNIPS AND RUTABAGAS}

A packet of turnip seed will sow 50 feet or more. One pound an acre in drills; 2 to 3 pounds an acre broadcast.

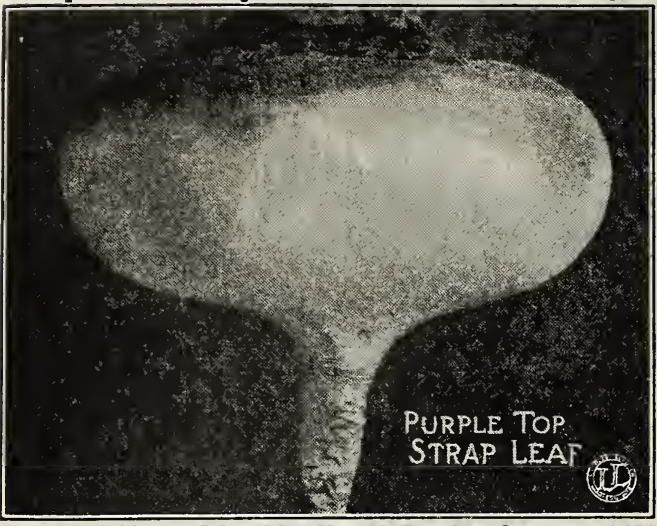

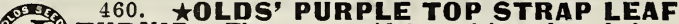
OT TRNIP The most widely cultivated and best known variety. A very early, productive sort. Largely grown for stock and also a great favorite for table use. Flat in shape, of medium size, purple abore grained. Many farmers sow this variety of turnip broadcast with their grain, one pound of seed per acre. It makes a wonderful pasture after harvest and costs practically nothing. Pkt., 10c; oz., 15c; 1/4 lb., 25c; lb., 100 lbs. or more, at $25 \mathrm{c}$.

463. WHITE FLAT DUTCH TURNIP. A popular table variety. Early, quick growing and tender; skin clear white; flesh juicy: flavor mild; shape flat. Pkt., 5c; oz., 10c; $1 / 4$ lb., 25c., lb., 65c; 5 lbs., \$2.75, postpaid.

467. COW HORN TURAIP. Pure white except a little shade of green at the top. Carrot shaped, slightly crooked and growing nearly half out of the ground, making it easy to harvest. Roots often 12 to 15 inches long and 3 inches in diameter. Pkt., 5c; oz., 10c; 1/4 lb., 25c; lb., 70c: 5 lbs., $\$ 2.85$, postpaid.

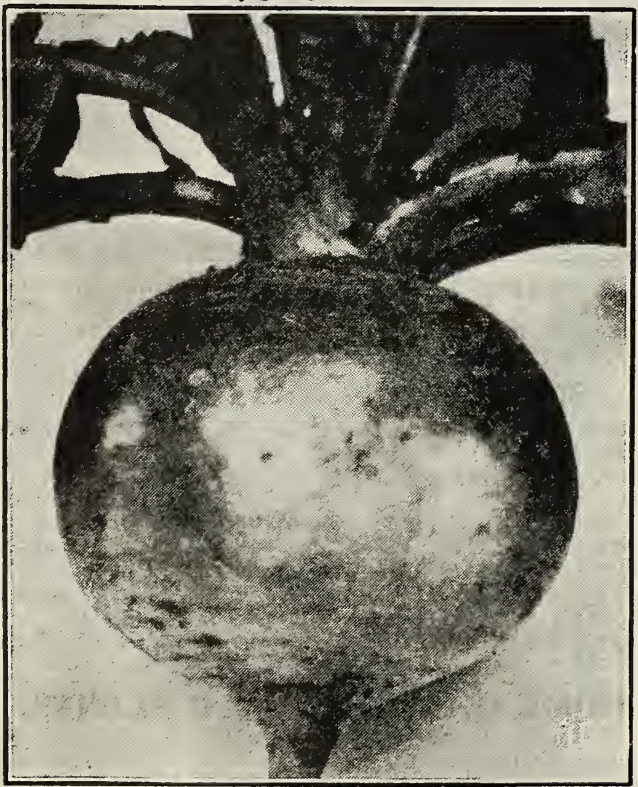

Purple Top White Globe Turnip.

ब59 465. †OLDS' PURPLE TOP WHITE GLOBE

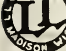
UR NIP

a perfect globe; a rapid grower, with pure white flesh; a sure cropper, and a great yielder. Much like Purple Top Strap Leaf except round instead of flat. Preferred by many on that account and largely grown for stock feed. Pkt., 10c; oz., 15c; 1/4 1b., 25c; lb. 75c; 5 lbs., $\$ 3.00$, postpaid. Not prepaid, 10 lbs. at $35 \mathrm{c}$; 100 lbs. or more at $25 \mathrm{c}$.

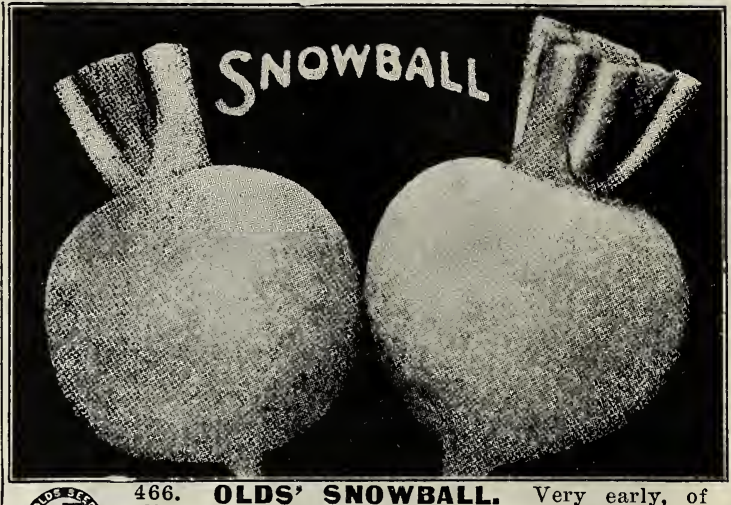

466. OLDS' SNOWBALL. Very early, of D. medium size, round as a ball. The most suitable white; flesh crisp, tender and very sweet-very desirable for sowing early. Pkt., 10c; 0z,. 15c; 1/4 lb., 25 c; lb., 75c; 5 lbs., $\$ 3.25$, postpaid

474. MIXED TURNIPS. By sowing this well bal anced mixture, you are assured purple, white and yellow turnips of long, round and flat shapes from early summer until winter. You will find it most interesting to try to identify each variety grown, from our catalog descriptions. Pkt., 5c; oz., 10c; $1 / 4$ lb., 20c; lb., 60c; 5 lbs., $\$ 2.50$, postpaid. Not prepaid, $10 \mathrm{lbs}$. or over at $30 \mathrm{c}$.
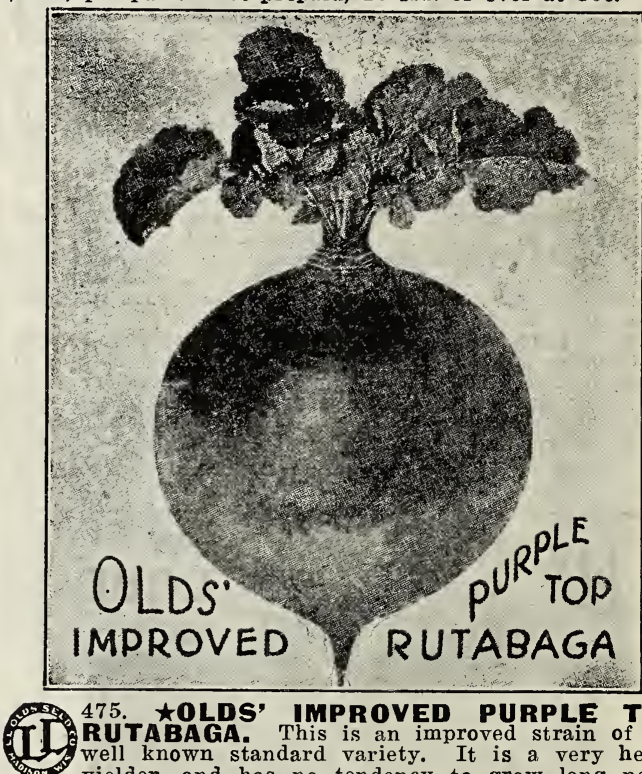

75. \OLDS' IMPROVED PURPLE TOP RUTABAGA. This is an improved strain of the well known standard variety. It is a very heavy yielder, and has no tendency to grow long necks as some varieties do. It is very hardy, a fine keeper, and very satisfactory for both table use and feeding stock. Roots are large, globe shaped, with a very small top root; color bright yellow with a purple top; flesh very solid tender and sweet. Pkt., 10c; oz., 15c; 1/4 lb., 25c; lb. $75 \mathrm{c} ; 5$ lbs., $\$ 3.00$, postpaid. Not prepaid, 10 lbs. or more at $35 \mathrm{c}$.

477. NEW NECKLESS RUTABAGA. The roots grow to a large size, and are almost globular in form. The flesh is fine-grained, of a yellow color, mild and sweet. Will keep until late in the spring. Very good for table use. Pkt., 5c; oz., 10c; $1 / 4$ lb., 25c; 1b., 65c; 5 lbs., $\$ 2.75$, postpaid.

SSP 479. †OLDS' GOLDEN HEART. A new rutaThag; flesh, fine-grained, very mild and sweet; an 2. excellent keeper, and in our opinion, the best of all varieties for the table and for feeding. It is a very heavy yielder and on account of its excellent shape is easily haryested. Pkt., $10 \mathrm{c}$; oz., $15 \mathrm{c} ; 1 / 4 \mathrm{lb}, 25 \mathrm{c}$; 1 . 75c; 5 lbs., \$3.00, postpaid. 


\section{OLDS' CHOICE FLOWER SEEDS}

\section{A Select List of Annuals and Perennials}

Our Flower Seeds are equal to the best offered anywhere. We have used great care in selecting the varieties and strains and our seed is from the very best flower seed growers of Europe and America.

Our descriptions are brief but we have tried to make them complete enough so that our customers will have $n$ difficulty in selecting just what they want. The meaning of the initial letters preceding each variety is as follows:

A. indicates Annuals; these grow, bloom and die the first year.

B. indicates Biennials; these grow the first year and bloom and die the next.

$P$. indicates Perennials; these grow the first year, bloom the second and from year to year thereafter.

H. indicates hardy plants. $\mathbf{H}$. $\mathbf{H}$. indicates half-hardy plants. $T$. indicates tender plants.

Thus H. H. A. would mean a half-hardy annual, and T. P. a tender perennial.

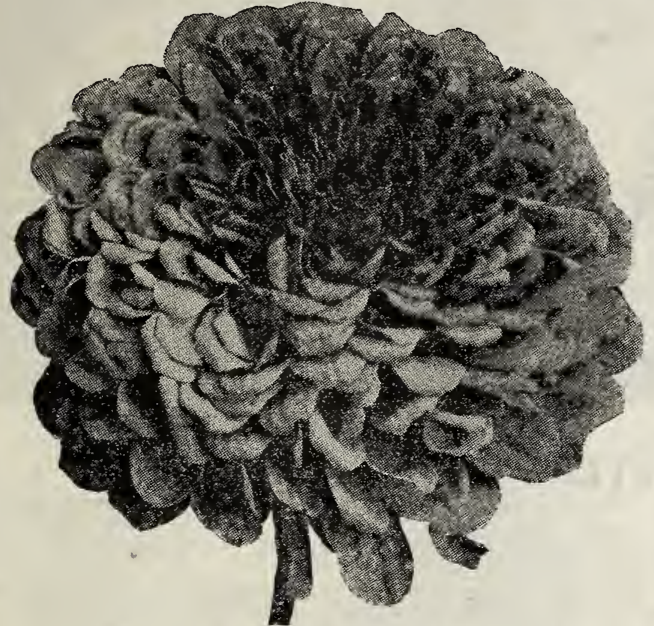

Olds' Gold Medal Dahlia Flowered Zinnia.

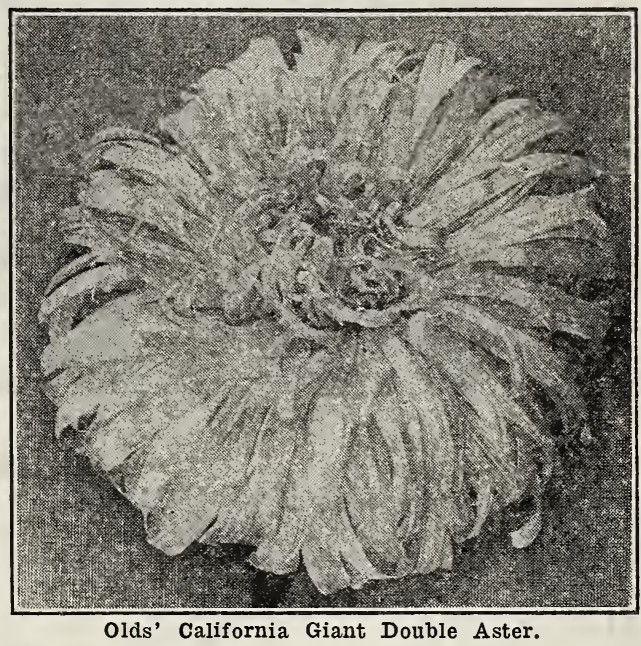

Olds' California Giant Double Aster.

\section{TWO NEW FLOWERS OF GREAT MERIT.}

\section{(1i)}

\section{6. $\star Z I N N I A$.} 1336. $\star$ ZINNIA. H. A. Olds' Gold Medal
Dahlia Flowered, Mixed. A new type of Zinnias

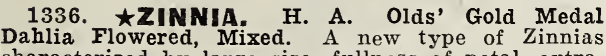
ordinaryed by large size, fullness of petal, extraResembling dahlias in range and good keeping quality. easily grown right from the seed of any flower in the entire list. It has been truthfully called "A new Flower for the People." Awarded a "Gold Medal" and "Award of Merit', by the Royal Horticultural Society of England in 1924 and two more awards of merit in 1925. Becoming very popular with florists as a good forcer.

The mixture we offer contains a wonderful assortment of color, ranging through all shades of red, pink, rose, orange, yellow, purple and white. Pkt., $15 \mathrm{c} ; 3$ pkts., $35 \mathrm{c}$.
817. ASTER. H. A. Olds' California Giant A Double, Mixed. The most popular new Aster. A combination of the sturdy habit of growth and long
stcms of the Beauty type of Asters with the wellknown Ostrich Feather type of large, graceful flowers. A true non-lateral type. Careful selection has not only perfected the type of this new Aster but has extended the color range making each color more intensive and strik. ing and of deep, rich shade. The colors are white, peach blossom, light blue, light purple, deep rose and dark purple. Our mixture combines all of these.

Every flower seed order should include at least one packet of this wonderful new Aster. We know it will give satisfaction to our customers as there is nothing equal to it today in the Aster line. Pkt., 20c; 3 pkts., 45c.

Note. Do not overlook our $10 \mathrm{New}$ Varieties of Sweet Peas on page 70 . Also the emphasis we give to other new and improved strains of different varieties of flowers throughout the Flower Seed pages. Decide that you will have plenty of flowers this year. They help wonderfully to make the home attractive and life worth living.

\section{FLOWER SEED COLLECTIONS.}

ANNUAL COLLECTION NO. 2

12 packets of seeds-value, $\$ 1.00$ for only $50 \mathrm{c}$, postpaid. Alyssum, Little Gem ...................... 0.10

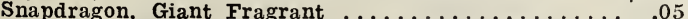
Bachelors Button, Mixed ............................... Balsam, Olds' Camellia Mixed. . . . . . . . Calendula, Double Mixed $\ldots \ldots \ldots \ldots \ldots \ldots \ldots \ldots \ldots . .05$

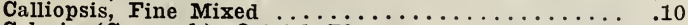

Celosia (Coxcomb), Ostrich Plume ..............

Cosmos, Extra Early Colossal Mixed $\ldots \ldots \ldots \ldots \ldots \ldots \ldots .10$

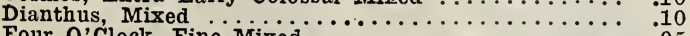

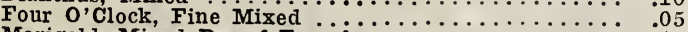

Marigold, Mixed Dwarf French $\ldots \ldots \ldots \ldots \ldots . .10$

Poppy, Olds' Finest Mixed .................

The entire 12 packets for $50 \mathrm{c}$, postpaid. $\$ 1.00$ COLLECTION NO. 4-ANNUAL VINES FROM SEEDS. One packet each of the following six vines-value $50 \mathrm{c}$, for $25 \mathrm{c}$, postpaid.

Cypress vine $\ldots \ldots \ldots \ldots \ldots \ldots \ldots \ldots \ldots \ldots \ldots \ldots \ldots \ldots \ldots \ldots \ldots \ldots \ldots$

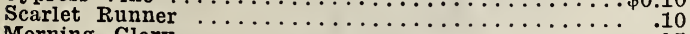

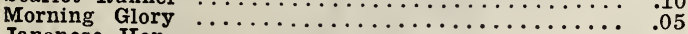

Japanese Hop $\ldots \ldots \ldots \ldots \ldots \ldots \ldots \ldots \ldots \ldots \ldots \ldots \ldots . .10$

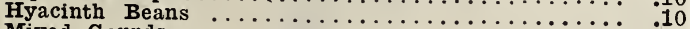

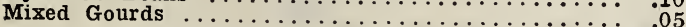

All 6 packets for 25c postpaid.

\section{SEMESAN MAKES SEEDS HEALTHY}

\section{TREAT YOUR FLOWER SEEDS WITH SEMESAN.}

Through controlling or preventing infection by the common diseases to which flowers are subject, Semesan increases germination and produces larger yields of finer blooms. Costs only $1 / 4 \mathrm{c}$ to $1 \mathrm{c}$ per pound of seed. Easily applied in either dust or liquid form. Recommended by expert and practical growers of flowers in all sections of the country. For both annuals and perennials.

Ask for free flower booklet, "Beautiful Fragrant Flowers with Semesan.'

Prices: 2 oz. size, 50c; $8 \mathrm{oz}$. size, $\$ 1.60$; 1b., \$2.75. (Not mailable.) The same article can be used for Vegetable Seeds.

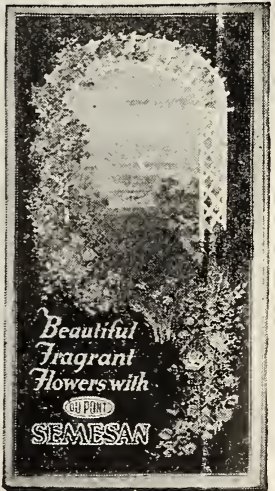




\section{OLDS' FLOWER SEEDS}

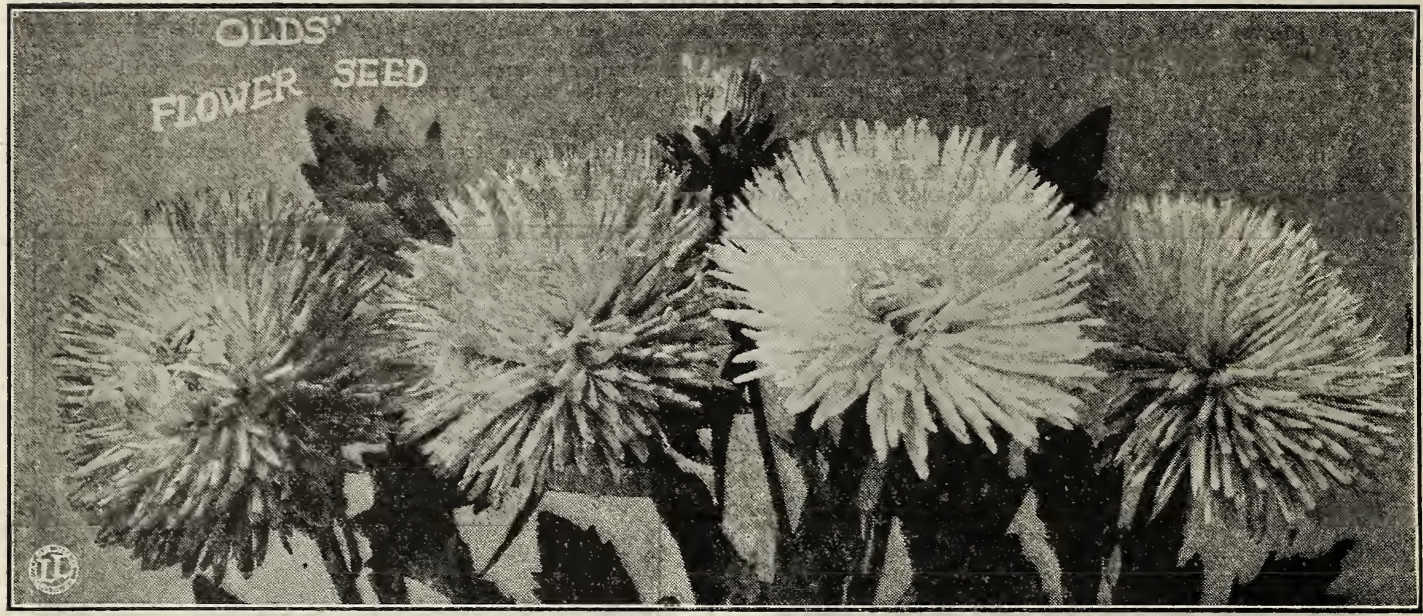

Olds' Finest Mixed Asters.

\section{OLDS' ASTERS}

Asters are the most desirable of all autumn flowers for bouquets and gardens, for during the late summer and early fall when all nature is a riot of reds and yellows, they produce the blues and purples that perfect and blend the color scheme. Asters are more popular with American flower lovers than any other fall annual, nor does any flower deserve its popularity more. Our seed is the best California grown.

800 . ${ }^{800}$. ${ }^{2} \mathrm{Old}^{\prime}$ Finest Mixed. This is a mixture of a splendid assortment. Our leader in asters. In$8001 \%$. Royal Mixed (Early Flowering). A new class of American aster. Very large double flowers with distinctly incurred shell-shaped petals. Earlier than most varieties and remaining longer in bloom. Pkt., 10c.

802. Giant Comet Mixed. Immense double flowers, resembling chrysanthemums. Pkt., 10c.

5s. 802 $\frac{1}{2}$. ' $\star$ Olds' Giant Branching (Mixed). The I finest of all asters for cutting. Large vigorous 2 plants, bearing a great profusion of bloom; im

$8031 / 2$. $\star$ Sensation. This is the Plkt., 15c. all red asters. The bricht color glistens in the sunshine like a live coal. Flowers double, recurved. Pkt., 10c.

$804 \frac{1}{2}$. đGiant White (Branching). One of the best white asters. Four inches in diameter. Pkt., 10c.

8051/2. Giant Shell Pink (Branching). The best clear light pink. Large flowers, graceful in form. Pkt., $5 \mathrm{c}$.

806. White Ostrich Plume. Without doubt one of the finest asters grown. Large, graceful flowers free from all stifiness; rery suitable for cut flowers. Pkt., $10 \mathrm{c}$.

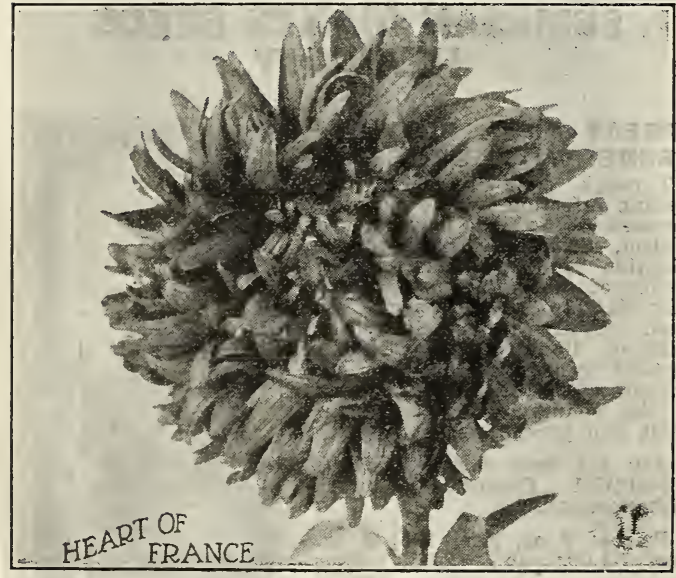

805. $\star$ Heart of France. The Test pure red aster ever introduced; flowers large and full, purest ruby. Commands instant admiration for its striking beanty. Pkt., 20c.
8071/. Giant Crimson (Branching). A new variety with conspicuously bright red flowers, very double. $\AA$ mass of them produces a splendid effect. Pkt., 10c.

808. $\star$ White Perfection. The finest midseason white aster: flowers four inches in diameter, produced on tall upright stems. Flowérs pure white and double; of perfect form, with broad, slightly folded petals. Pkt., 10c.

$8081 / 2$. Giant Blue (Branching). Almost a pure lavender shade, approaching an azure blue. Pkt., 5c.

8091/2. Giant Purple (Branching). A rich violet or purple. One of the best dark-shaded varieties. Pkt., 5c.

812. \Alice Roosevelt. Large yellow flowers changing to flesh color. Pkt., 10c.

8s 819. *Olds' Everlasting Aster. A curious new AsTI ter resembling a Helichrysum. For several years 2. it has been grown in the trial grounds of our grower and has retained its original peculiar character. istics. When cut and dried it has the color and shape of an everlasting flower. Plant early in the spring. Pkt., 25c.

Royal Mixed. Fint early flowered for bedding. olds' Giant Branching. Mixed colors, long stemmed, the finest aster for cutting. Doz., 40c; 50 for $\$ 1.25$, postpaid.

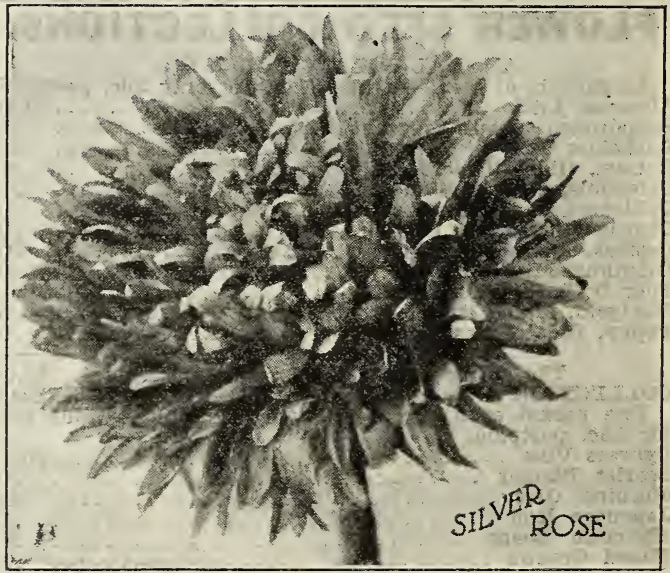

$812^{1 / 2}$. $\star$ Silver Rose. A robust, long-stemmed, largeflowering new variety. Ashes of roses exactly describes the color of this new Aster. Very beautiful. Pltt., $15 \mathrm{c}$. 


\section{OLDS' FLOWER SEEDS}

820. ABUTILON. T. P. (Flowering Maple, Chinese Bell Flower.) A quick-growing plant with large, mallow-like, pink or red blossoms. Pkt. $15 \mathrm{c} ; 4$ pkts., $50 \mathrm{c}$.

825. AGERATUM. H. H. A. (Floss Flower, Paint Brush.) One of the best bedding plants, bearing the bright blue flowers in greatest profusion from early summer until frost. They thrive throughout the hot dry months of summer, are uninjured by rain, and their colors do not fade. Easily raised from seed. Pkt., $10 \mathrm{c}$.

831. ALYSSUM, SWEET. H. A." (Carpet Flower.) Little Gem. Carpet of snow. One of the finest annuals we have for edging, and much loved for its modest blossoms, white and honey scented. A mass of bloom from spring until late autumn. Pkt., $10 \mathrm{c}$.

ANTIRRHINUM. See Snapdragon, page 69.

845. $\star A Q U I L E G I A$. H. P. (Columbine.) Poised on slender swaying stems like graceful birds, the blossoms appear to be hovering but a moment before darting away. Exquisitely dainty flowers, spurred and honey-laden. Pkt., $10 \mathrm{c}$

850. ASPARAGUS FERN. T. P. Plumosus Nanus. (Lace Fern.) The daintiest and airiest of all the ferns. Very easy to grow from seed and may be started at any time. Pkt., 15c.

BABY'S BREATH. See Gypsophila. No. 994, page 66

855. $\star B A C H E L O R ' S$ BUTTON. H. A. (Centaurea, Corn Flower, Blue Bottle, Ragged Sailor, etc.) Mixed. Although not a pretentious plant, Bachelor's Button is one of the popular, hardy, old-fashioned annuals. Re-seeds itself and is excellent for winter dried flowers. Pkt., 5c.

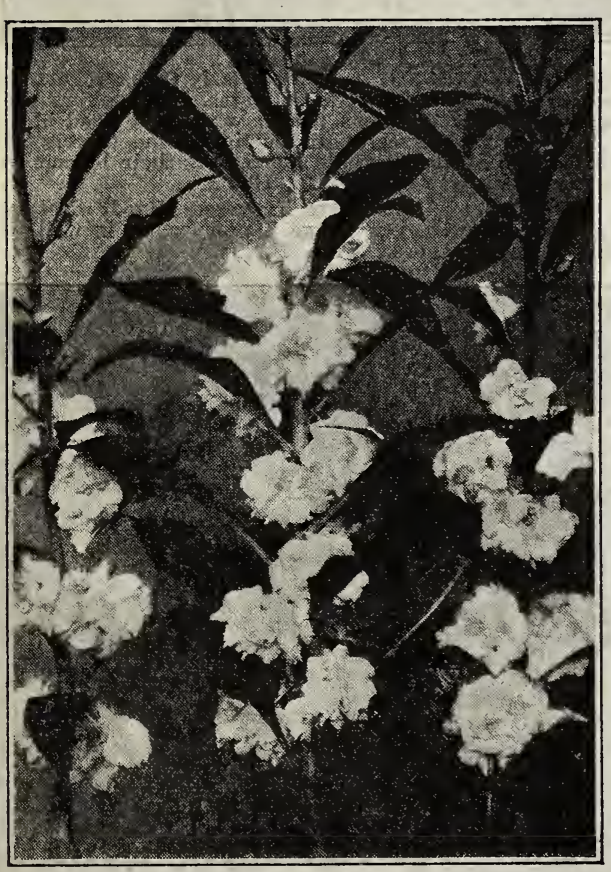

Balsam.

B I A N K E T

FLOWER. S Gaillardia, No. 985 .

FLOWER. See Schizanthus, No, 1160 .

867. †CALENDULA. H. A. The Ball. A particularly fine, new variety of Calendula or Pot Marigold. It has immense double flowers of a brilliant, glistening orange color, borne on long stems. Already becoming very popular as a cut flower. Specially fine for floral pieces. Pkt., $15 \mathrm{c}$.

865. CALENDULA. H. A. (Pot Marigold.) Double Mixed. Freely flowering plants of easiest culture, succeeding everywhere a $n$ d flowering continuous. 1y. Flowers double, showy and of large size; orange-colored. Pkt., $5 \mathrm{c}$.

866. †CALEN. DULA. H. A. Orange King. A very select, double, dark orangered calendula. Blossoms often $3 \frac{1}{2}$ inches in diameter. Pkt., $10 \mathrm{c}$.

880. C A N A R Y BIRD FLOWER. $H$. A. A dainty vine with ornamental cut leaves, and dainty, canary-yellow flowers of curious shape. So called from the color of its blossoms and also from a fancied resemblance of their shape to a bird with open wings. Pkt., 10c.

885. C A N D Y TUFT, H. A. Olds Choice Mixed. Well known, hardy plants, much used $f$ o $r$ borders and edging. Easy to grow. Season, July' till heavy frost. Height, on foot. Pkt., $10 \mathrm{c}$.

C A T H E D RAL BELIS. Pkt., 10c. See Cobaea Scandens. No. 920 .

877. $\star$ CALLIOPSIS. H. P. (Coreopsis) Lanceolata. One of the finest of the hardy perennials, bearing a constant succession of large, showy, yellow flowers. Pkt., 10c.

COREOPSIS PLANTS. See page 79

898. CARDINAI CLIMBER. H. A. A very handsome vine with finely cut ornamental foliage: a strong, rapid grower attaining a height of 25 feet, and covered with a blaze of fiery, cardinal red flowers, somewhat resembling small, Morning Glories with the bell turned back. These flowers are about one inch in diameter and are borne in clusters of five to seven. It does best in a warm, sunny location and good, rich soil. Pkt., 15c.

CASTOR BEAN'S. Pkt., 10c. See Ricinus; No. 1140.

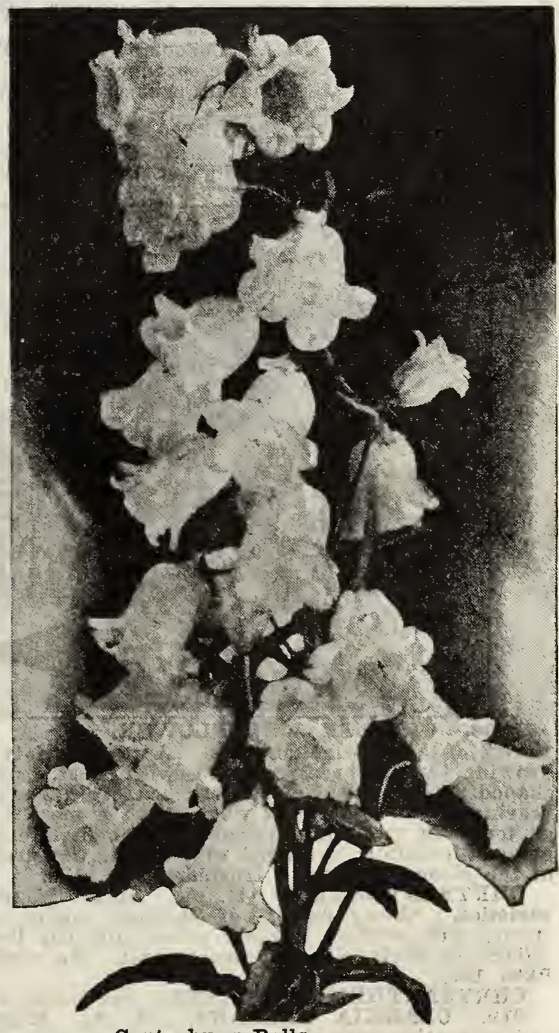

Canterbury Bells.

895. CANTERBURY BELLS. H. Mixed. The spikes of this imposing biennial are covered with large, blue and white, bell-shaped flowers. Pkt., 10c

CANTERBURY BELLS PLANTS. See page 79.

890. CANNA. H. A. Crozy's Best Mixed. Height, $2^{1 / 2}$ to 8 feet. Grent clusters of brilliant bloom, borne on tall spikes, surmounting broad leaves of green, bronze or purple, giving a tropical effect. Easily grown from seed if planted early. Plst., $10 \mathrm{c}$.

CANNA PLANTS. See page 76. 


\section{OLDS' FLOWER SEEDS}

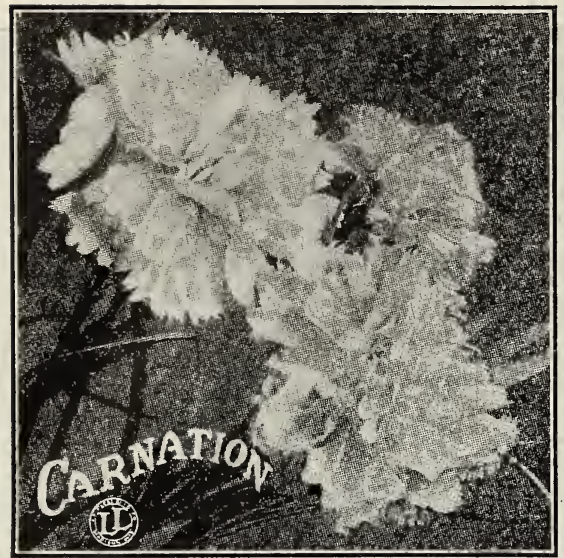

New Giant Marguerite Carnation.

900. CARNATION. H. H. P. New Giant Marguerite. Free blooming, spicy-scented, double, fragrant flowers, nearly 3 inches across. Pkt., 15c.

901. CARNATION. H. H. P. Yellow Marguerite. A unique color in carnations. Pkt., 10c.

$9001 / 2$. CARNATION. H. P.' Dwarf Vienna Mixed. Quite hardy with ordinary protection. Large, double flowers, produced in succession all summer. Excellent for beds and also valuable for cut flowers. Pkt., 10c.

905. CELOSIA. H. A. (Coxcomb) Ostrich Plume. Very hardy annuals of easy culture, producing large, ornamental, comb-like heads like ruffled crimson chenille. Marooncolored leaves. Pkt., 10c.

911. CENTAUREA IMPERIALIS. H, A. Sweet Sultan. Beautiful, sweet-scented thistle-like flowers borne on long, strong stems. When cut, will last for days in water. Very easy to grow. Pkt., $10 \mathrm{c}$.

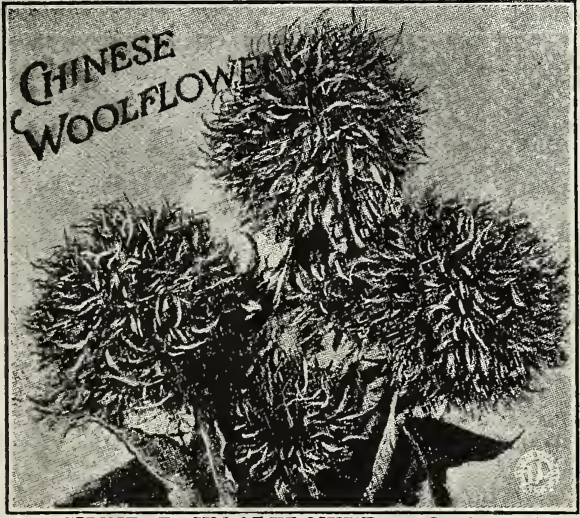

1303. CHINESE WOOLFLOWER. H, A The most showy of all garden annuals. A new variety of Celosia growing two to three feet high, with great, crimson, globeshaped heads. Scores of branches are thrown out, each bearing a ball of scarlet wool. The numerous flowers together with the bright green leaves look like an immense bouquet carefully arranged and set in the ground. None of the blooms fade until frosted. Pkt., 15c.

CHRYSANTHEMUM. H. A. Single Mixed. Annual varieties. Showy flowers of pleasing shades, growing on strong stiff stems. Largely grown for cut flowers. The foliage is finely cut and ornamental. An autumn flower. Pkt., 10c

CHRYSANTHEMUM PLANTS. See pages 79 and 80 .

919. CLARIIA ELEGANS. H. A. Mixed. Bright and attractive annuals of easy culture They orow about 2 feet high, bear profusely; pretty double flowers carried on long graceful sprays. Pikt., $10 \mathrm{c}$.

920. COBAEA SCANDENS. H. A. (Cathedral Bells.) One of our finsst and most rapid growing climbers, attaining $a$ height of 30 feet during the season; fine for covering porches, trellises, arbors, tree-trunks, etc. will cling to any rough surface. In sowing, place the seed edgewise, in-doors in March or April. The large bell-shaped flowers are first green then turn to a beautiful purple. Pkt., 10c.

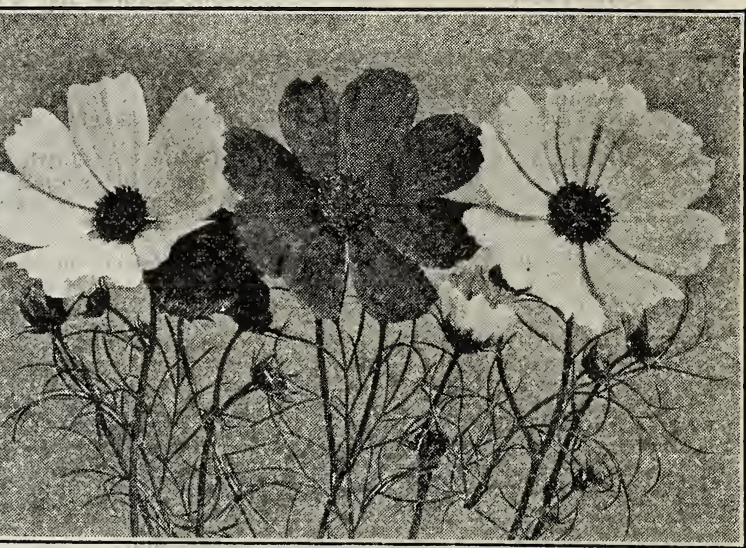

Cosmos-Extra Early Colossal.

9261/2. †COSMOS. H. A. Extra Early Colossal Mixed, The best Cosmos for the northern states, for it offers the combination of extra earliness (July) with good sized blossoms. The plant is graceful and delicate, the flowers as large as the late blooming kinds, perfecting their blooms in our most northerly sections. Pkt., 10c.

925. COSMOS. H. A. Giant Flowered Mixed. Not as early as some but with very large blossoms. It is well to start this variety indoors. Pkt., $10 \mathrm{c}$.

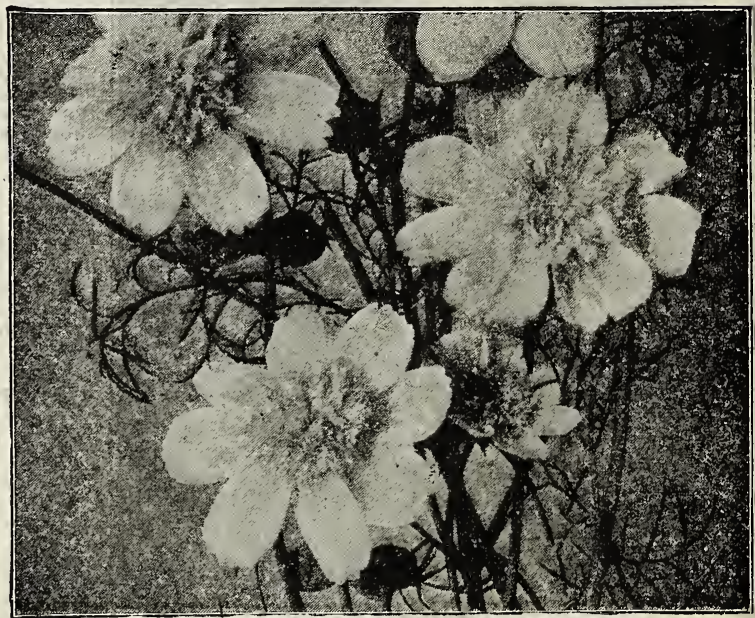

\section{Cosmos-Double Early Flowering Mixed.}

9251/2. COSMOS. H. A. Double Early Flowering Mixed. Grows about three feet high, forming a perfect bush massed with blooms The double crested center is ed ged with a row of single, flat petals, but varies considerably in the degree of doubleness. Very early. Pkt., $15 \mathrm{c}$.

933. CYCLAMEN. T. P. Giant Flowered. A charm. ing house plant with rich-colored flowers, whose beauty of form is enhanced by the reversed petals. Pkt. of 15 seeds, $15 \mathrm{c}$.

930. CYPRESS VINE. H. H. A. Mixed. Unexcelled for training up a light ornamental trellis. Bears many star-shaped, scarlet or white blossoms; finely cut leaves. Prt $10 \mathrm{c}$.

DELPHINIUM. Pkt., 10c. See Larkspur, No. 1015.

958. DIGITALIS. H. P. (Foxglove.) Gloxiniaefiora.

Handsome stately plants of imposing mien, giving a wealth of flowers during June and July. Pkt., 10c.

DIGITALIS PLANTS. See page 78 .

"'Outdoor Flowers for the Home." A 28 page bulletin by Prof J. G. Misconsin College of Agriculture. Free on request with an order of $\$ 1.00$ or over. 


\section{OLDS' FLOWER SEEDS}

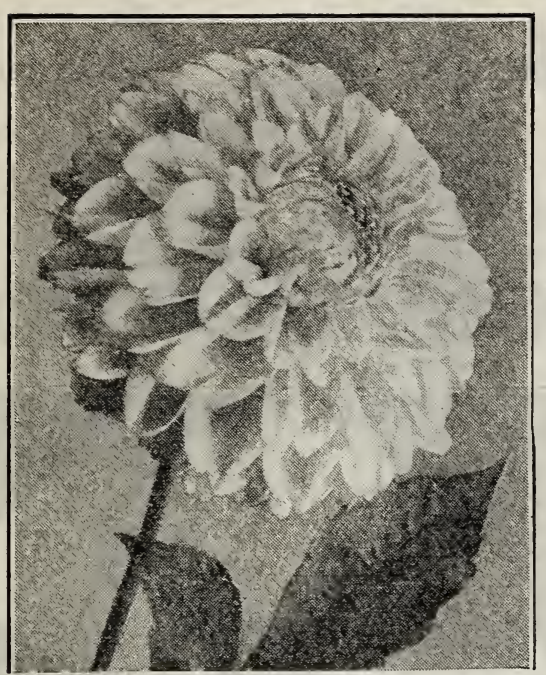

Dahlias From seed.

DAHLIAS can be easily grown from seed so as to bloom the first year. Plant in a box in the house in April, and transplant.

935. DAHLIA. H. A. Double Mixed. Large flowering. Pkt., 15c.
Note. Do not orerlook our Dahlia bulbs, pages 74 and 75 . We have a large list of splendid varieties and splendid bulbs.

940. DAISY. H. P. Fine Mixed. Few flowers are mcre universally loved than daisies, celebrated in song and rhyme from time immemorial. Pkt., $10 \mathrm{c}$.

9431/2. DAISY. H. A. Arctotis (Blue-Eyed African Daisy.) Plants quickly form bushes 2 to 3 tcet across with deep-cut silver foliage and large blossoms of silverwhite with blue eye. Underside of petals bluish. Pkt., 5c.

944. DAISY. H. P. Shasta Giant. See illustration on page 79. A splendid hardy perennial producing, on stout stems, great flowers 5 inches in diameter with pure white overlapping petals. Pkt., 10c.

DAISY PLANTS. Page 79 .

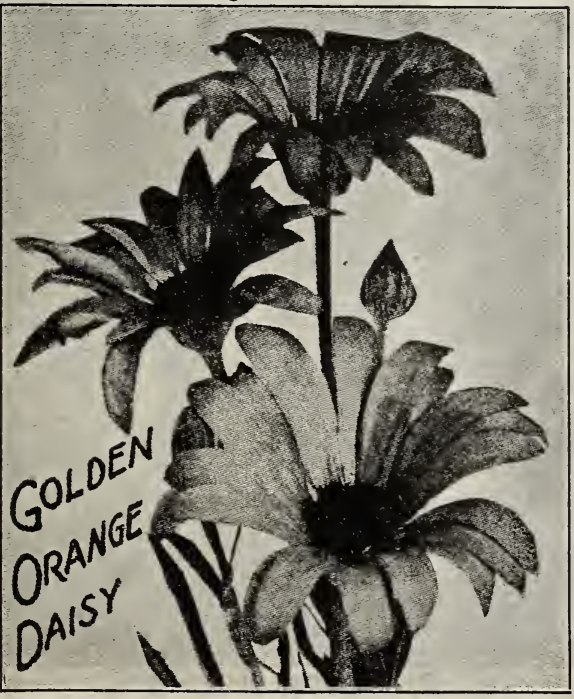

944 1/2. \DAISY. H. A. Golden Orange. A rare and showy African Daisy with large, glossy, orange-red flowers which glitter in the sun. Pkt., 10c.

960. DOLICHOS. H. A. (Hyacinth Bean.) A rapidgrowing, free-flowering annual climber; blossoms and later, ornamental pods, borne on erect racemes. Pkt., 10c.

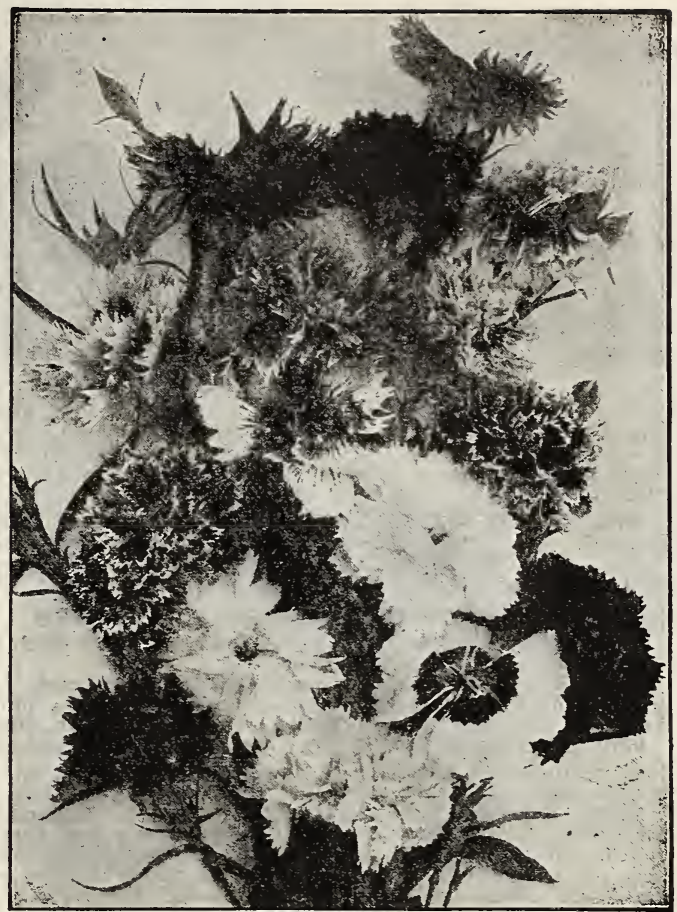

Mixed Annual Dianthus or Pinks.

950. DIANTHUS. H. A. (Pinks.) Mixed. One of the most loved of all annuals. The brilliant contrasting colors appearing in each flower form stripes, bands and markings and are very berutiful. Pkt., 10c.

957. DIANTHUS. H. P. Plumarius., (Clove Pink.) A beautiful hardy perennial single pink with fringed edged flowers in various colors. Pkt, 10c

970. FORGET-ME-NOT. H.'A. (Myosotis.) One of the best spring flowers and a great favorite. A sea of blue. The national flower of Belgium. Pkt., 10c.

975. FOUR O'CLOCK. H. A. (Marvel of Peru.) Mixed. Handsome, free-flowering many colored blossoms. A good, old-fashioned flower of hardy habit, very charming as a hedge plant. Pkt., $5 \mathrm{c}$.

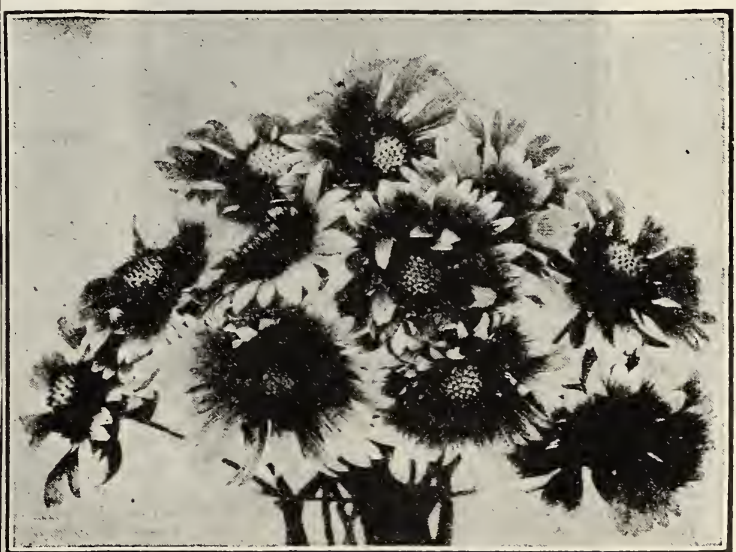

Hardy Perennial Gaillardia.

986. $\star$ GAILLARDIA. (Blanket Flower.) H. P. Hardy Perennial Mixed. Blooins continuously through summer and fall, regardless of heat or drought. Flowers with brown center, surrounded with concentric rings of crimson, orange and scarlet, on the petals. Pkt., 10c.

985. . GAILLARDIA. H. A. Double Mixed. The annual Blanket Flower-reds and yellows. Pkt., 10c. 


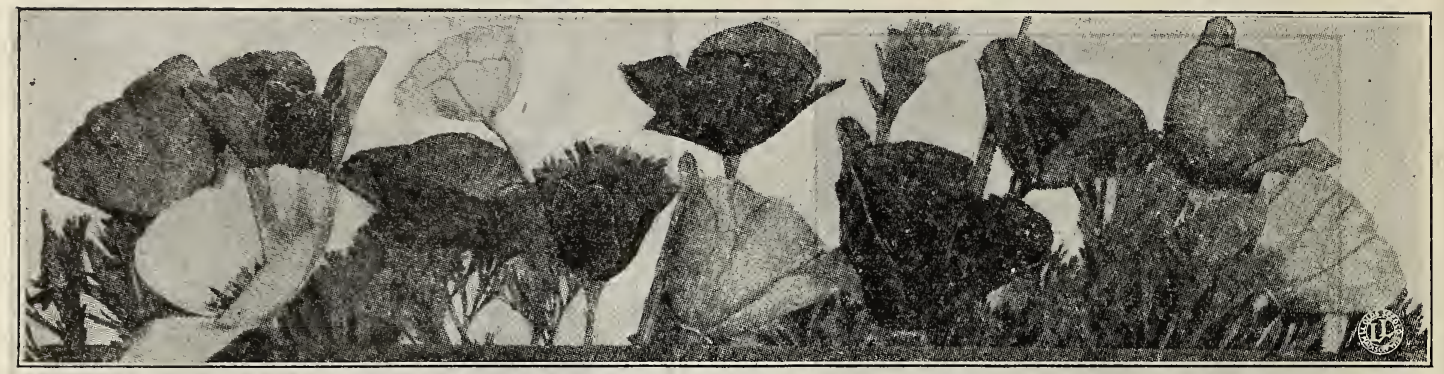

Eścholtzia or California Poppies. (Fine Mixed.)

870. CALIFORNIA POPPY. H. A. (Escholtzia.) Fine Mixed. The State Flower of California. A bright, freeflowering plant with finely-cut foliage and tulip-like flowers, generally of orange or yellow. Should be in every garden. Pkt., 10c.

872. $\star$ CALIFORNIA POPPY. H. A. Carmine King. Beautiful carmine-rose, both inside and out. Pkt., 10c. 873. CALIFORNIA POPPY. H. A. Golden. The true, wild California Poppy. Largest flowers. Pkt., 10c.

\section{STRAW FLOWERS OR EVERLASTINGS}

965. tEVERLASTING. H. A. Helichrysum Mixed. Double flowers in glittering colors. Pkt., $10 \mathrm{c}$.

967. EVERLASTING. H. A. Acroclinium, Mixed. A pretty annual 15 inches high, bearing lovely white or pink daisy-like blossoms. Lasts through the winter. Pkt., 10c.

966. EVERLASTING. H. P. (Sea Lavender.) Statice. Full panicles of small blue flowers all summer, which may be dried and used for winter bouquets. Pkt., 10c.

1026. SILVER DOLLAR PLANT. H. A. (Lunaria). Sometimes called Honesty Plant. The flowers are about the size of a silver dollar and purple but when the seed pods are removed they leave silver pods which remain on the stems. Prized for winter decorations. Pkt., 25c.

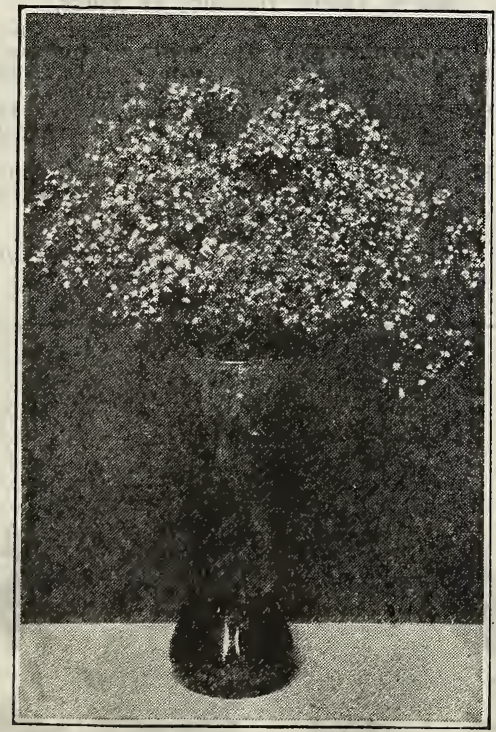

Gypsophila Paniculata or Baby's Breath.

GYPSOPHILA. (Baby's Breath.) The flowers are small, starlike, and borne in feathery sprays which are highly esteemed for cut flowers, as they lend a most graceful effect when combined in bouquets with Sweet Peas or other flowers. May be used for winter also.

993. GYPSOPHILA PANICULATA. H. P. The perennial kind. Pkt., 15c.

GYPSOPHILA PLANTS, see page 78.

994. GYPSOPHILA ELEGANS. H. A. The annual variety. Pkt., 10c.

Gladiolus Seed. See page 72 .

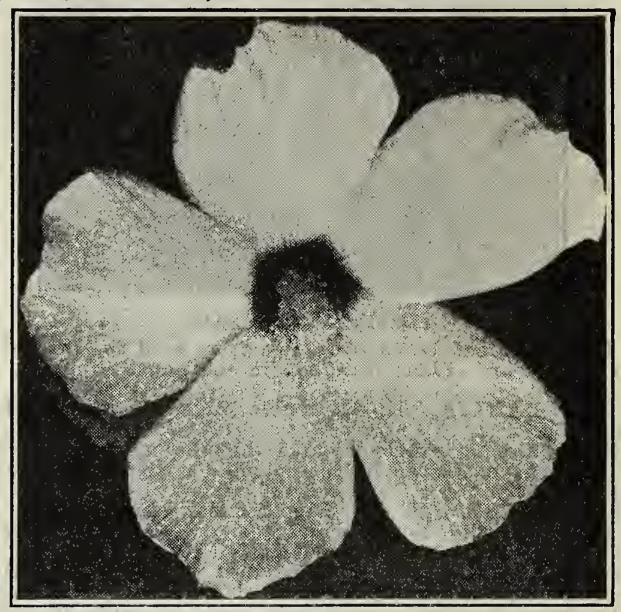

Hibiscus,

998. HIBISCUS. T. P. New Giant Flowering. Velvety petals of rich dark red, pink and white. Pkt., 15c.

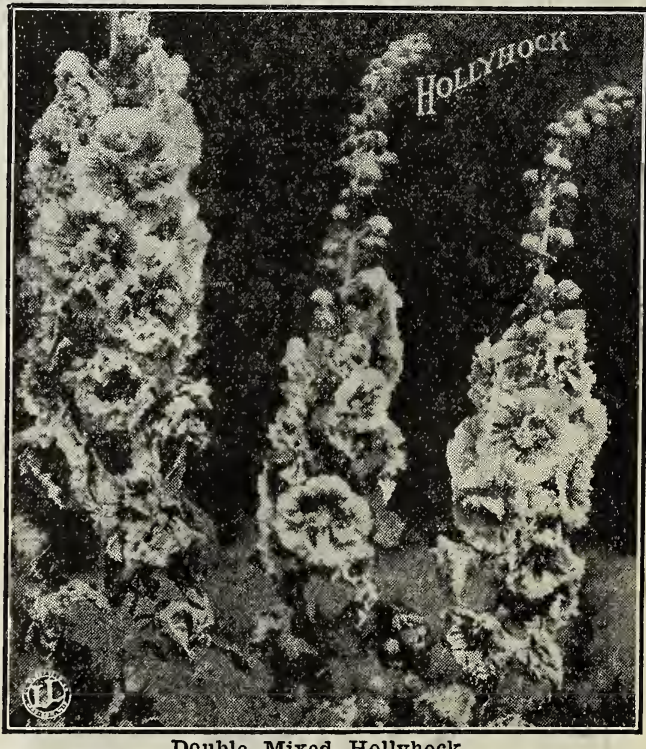

1005. $t$ Hor Double Mixed Hoty stalks of velvet bloom, Giant flowers of red and pink and white. Sow in June or July for flowers next summer. Pkt., 10c.

1007. †HOLLYHOCK. Annual Mixed. Tall spikes of satiny mallow flowers throughout the summer.. Pkt., 5c. 


\section{OLDS' FLOWER SEEDS}

987. GERANIUMS. T. P. Mixed. Blooming plants can be grown from seed the first rear. Pkt., $15 \mathrm{c}$.

GERANIUM PLANTS. See pages 82 and 83.

995. GOURDS. T. A. Mixed. Ornamental. Quickly makes a dense growth of vines. Pkt., $5 \mathrm{c}$.

997 GOMPHRENA. H. A. Best Mixed. (Globe Amaranth.) Sometimes called Bachelor Buttons. A showy annual ererlasting or straw flower with clover-like heads. No garden is complete without it. Pkt., 10c.

1000. HELIOTROPE. H. H. P. Choice Mixed. Flowers from seed the first rear. Delicate blue and white flowers continuously appearing. Loved most for its fragrance. Pkt., $10 \mathrm{c}$.

1010. HUMULUS. H. A. Japonicus. (Japanese Hop.) A fine porch vine. Makes a rapid growth. Pkt., 10c.

1012. ICE PLANT. T. A. A dwarf trailing plant with fleshy foliage covered with "crystals." Pkt., 10c.

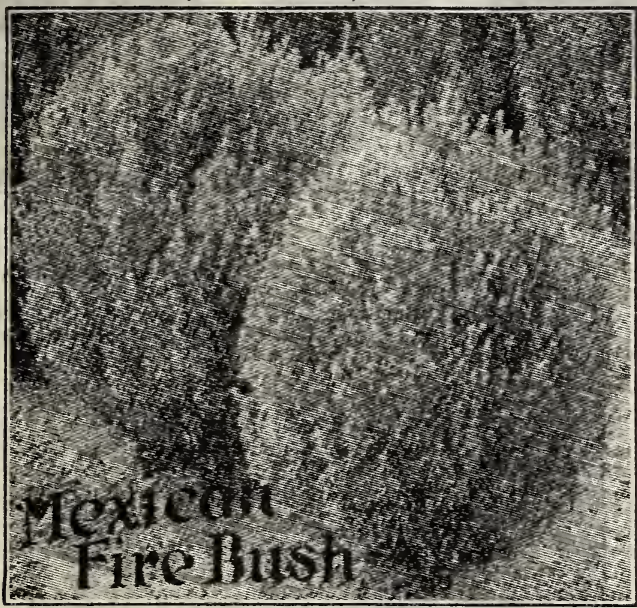

1013. $\star$ KOCHIA. H. A. Mexican Fire Bush. A beau tiful hedge plant. A rapid grower, producing globe-shaped bushes of finely cut small green leares and stems, which change in the early fall to carmine. Pkt., 10c.

1025. LOBELIA. H. A. Mixed Dwarf. Compact, bushy little plants about 6 inches high and covered with little, bright blue flowers. Pkt., 10c.

1030 †MARIGOLD. H. A. Mixed French. The favorite, dwarf highly-colored variety, Pkt., 10c.

1031. MARIGOLD. H. A. Lemon Queen. Large, double-quilled African Marigolds. Very showy. Pkt., 10c.

1035. MIGNONETTE. H. A. Mixed. Of' dwarf, pyramidal form; numerous branches; very fragrant. Fine for combining in bouquets. Pkt., 10c.

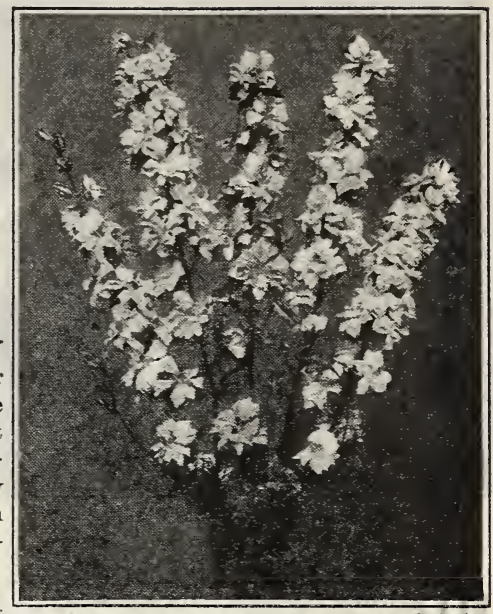

Fine Mixed Larkspur or Delphinium:
GROW STRAW FLOWERS for winter use. Se list of different styles on preced ing page. They are easily grown and very satis factory.

1015. $\star$ LARKSPUR. H. A. Fine Mixed. (Delphinium, Tall Rocket.) Tall old-fashioned spikes of blue. Pkt., 10c.

1017. LARKSPUR. H.. P. Belladonna. Spires of bluest hue. This hrbrid strain is of wonderful beauty; growing up to six feet in height and outmatching all other flowers around it in showiness. A splendid Perennial Larkspur. Pkt., 10c.

DELPHINIUM PLANTS. See page 78 .

1045. MORNING GLORY. T. A. Imperial Japanese. A wonderful array of color-pure white through all shades of blue and red to the darkest purple. Pkt., 10c; oz., 30c. 1047. MORNING GIORY. H. A. Tall Mixed. The beautiful, old-fashioned, common Morning Glory. Pkt., 5c; oz., $15 \mathrm{c}$.

1048. tMORNING GLORY. T. A. Sakata's Mammoth Flowered. The largest and most magnificent of Jap. anese Morning Glories, with great blossoms nearly six
inches across and figured with stripes and markings. Pkt.,

1040. MOONFLOWER. H. A. Mixed. A fine, ivtleaved climber, covered every evening and cloudy day with large, fragrant flowers. Fkt., 10c.

1072. NIGELLA (Love in the Mist.) H. A. Best Mixed. A compact flower with finely cut foliage; has curious looking seed pods; of easy culture. Pkt., $10 \mathrm{c}$.

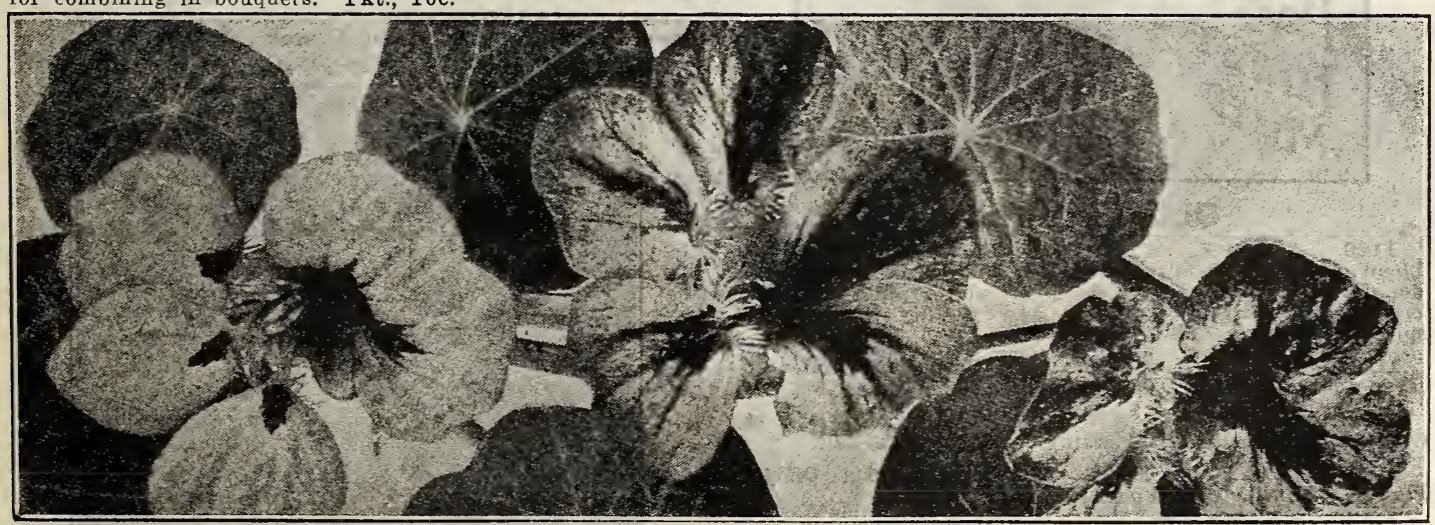

Olds' Tall Mixed Nasturtiums.

\section{OLDS' NASTURTIUMS}

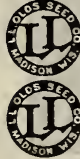

1060. -NASTURTIUM. Olds' Tall Mixed. H A No annul is more easil grown than the Nasturtium and nothing surpasses it in duration of bloom or in brightness of color. If you want a supply of condensed sunshine all summer long sow some of Olds' Tall Mixed Nasturtium seed. These are the freest bloomers and produce the largest flowers. Large pkt., 10c; 0z., 30c; 1/4 1b., 55c; 1b., \$1.75, postpaid. 1050. tNASTURTIUM. Olds' Dwarf Mixed. H. A The Drarf Nasturtiums are best adapted to sowing in beds or for borders. Olds' Dwarf Mixed comprise a wonderful assortment of rich and raried shades from dark crimson through all shades of red and orange to light yellow and almost white. Large pkt., $10 \mathrm{c}$; Oz., $25 \mathrm{c}$; $1 / 4$ lb., $50 \mathrm{c}$; 1b., $\$ 1.50$. 


\section{OLDS' FLOWER SEEDS}

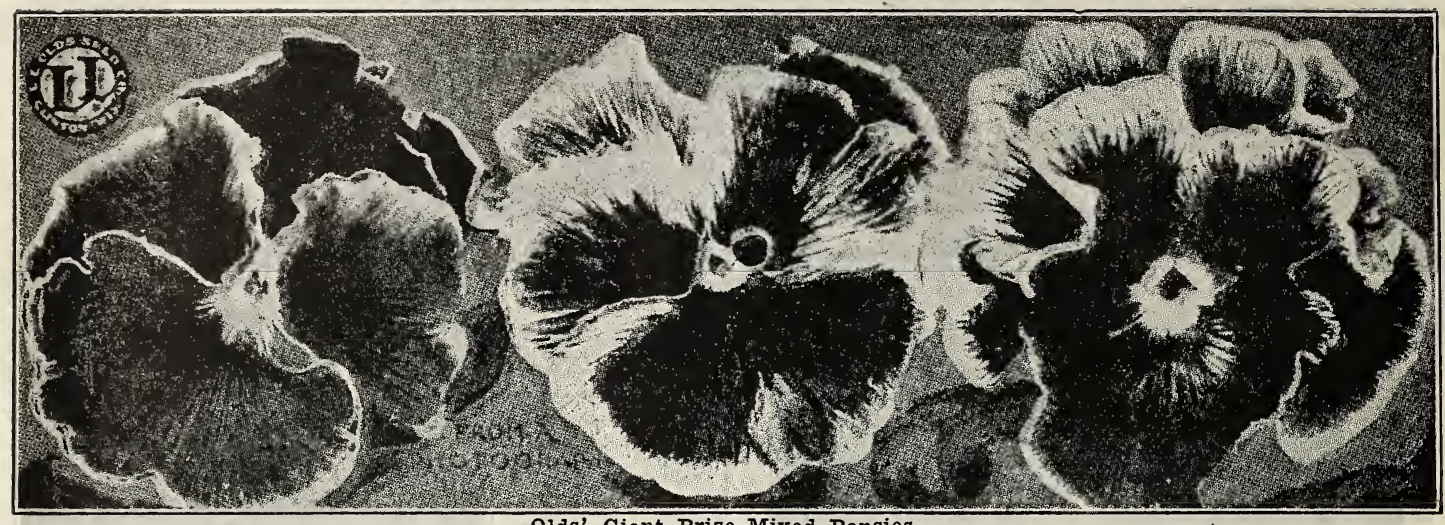

\section{Olds' Giant Prize Mixed Pansies.}

\section{OLDS' PANSIES}

0978 1075. $\star$ Olds' Giant Prize Mixed. P. The largest, 6 richest flowers, ranging in color from pure white through bronzes, browns, yellows and blues. Pkt.,

1077. 'Olds' Large-Flowering. P. A superb mixture producing a great variety of charming colors. Pkt., 20c.

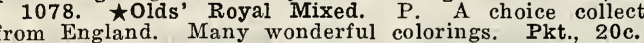

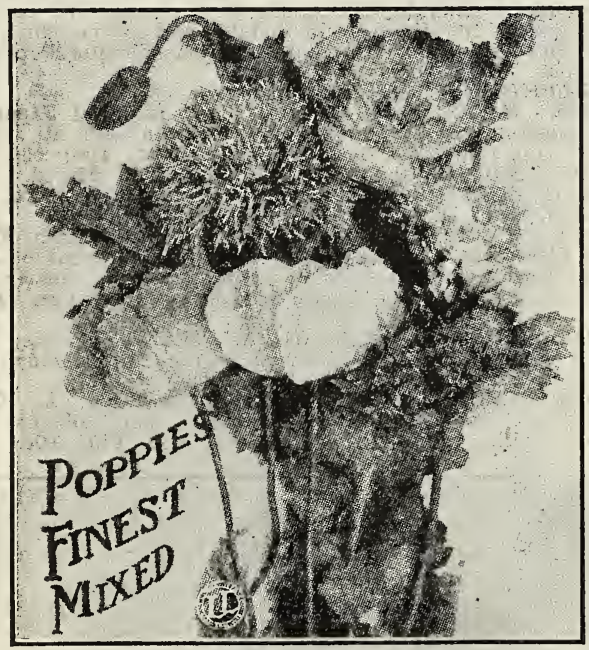

OLDS' POPPIES

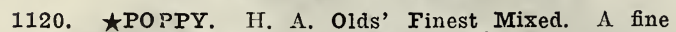
blend of many handsome shapes and sizes; many are double and shaped like a ball, in white, pink and red; massive Carnation Poppies and dainty Shirleys. A splendid mixture. Pkt., 15c.

1121. POPPY. H. A. Improved Carnation. Splendid large double flowers of many shades. Pkt., 10c.

1122. $\star$ POPPY. H. A. Reselected Shirley. Silk or Ghost Poppies. Beautiful satiny flowers. Pkt., 10c.

$11261 / 2$. POPPY. H. A. American Legion Official Flower. Mixed. Vivid scarlet. Pkt., 10c.

1128. $\star$ POPPY. H. P. Iceland Mixed. Hardy perennials blooming the first season. Bright, fern-like, evergreen foliage. Pkt., $10 \mathrm{c}$.

11281/2. POPPY. H. P. Red Oriental. Fine perennial plants 3 feet tall, of rather massive form and bearing bright scarlet flowers 6 inches across. Pkt., 10c.

ORIENTAL POPPY PLANTS. See page 78.

11291/2. POPPY. H. A. King Edward. A very freeblooming annual variety; the plant is 30 inches tall with gorgeous deep-scarlet petals. Pkt., 10c.
1079. $\star$ Giant Trimardeau Mixed. P. An extraordinary strain of Pansy. Very large flowers. Pkt., 10c.

1083. March-Flowering. $P$. These pansies are much favored, owing to the extreme hardiness of the plants and their early-flowering habit. Pkt., 15c.

PANSY PLANTS. See page 79.

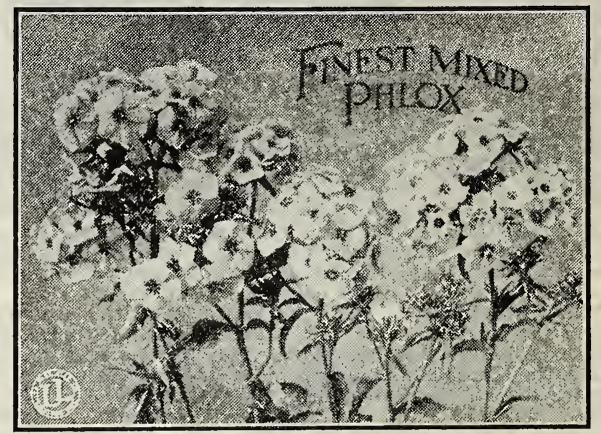

PHLOX DRUMMONDII. H. A. Beautiful and showy. 1110. $\star$ OLDS' FINEST MIXED. A splendid mixture of many pleasing colors and varieties. Pkt., $10 \mathrm{c}$.

1114. STARRED AND FRINGED. Pretty star-like flowers of many colors, some fringed. Pkt., $10 \mathrm{c}$.

FOR PHLOX ROOTS. See page 77.

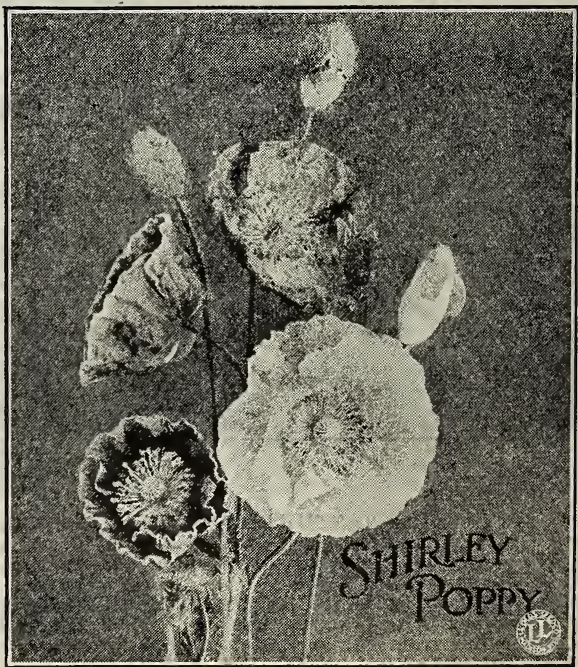




\section{OLDS' FLOWER SEEDS}

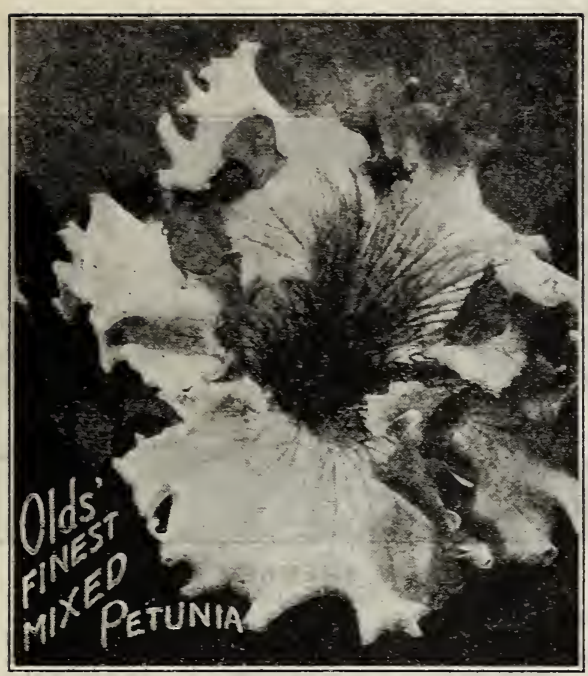

1155. SCABIOSA. H. A Double Mixed. (Mourning Bride.) Sometimes called Pincushion. A rariety of IIt colors and shacles. II sweetness attracts all kinds of bees and butterdies to the neighborhond. Plkt. $10 \mathrm{c}$.

1115. SALPIGLOSSIS H. A. (Painted Tongue. A rery attractive annua With slender stems bearing lily-sh a o d flowers reined with gold. Pkt., 10c. 39. SCARIET RUNNER BEAN. T.A. A vigorous Producino bright scarlet flowers. Pkt., $10 \mathrm{c}$

1165. SMIIAX. T. P Delicate climber of glossiest rreen; used in hanging bas kets and in bouquets. Pkt. $10 \mathrm{c}$.

1172. T E N WEEKS STOCKS, Iarge Flowering. Mixed. The flowers appear on long stiff stalks like small rosettes. They are exceedingly fragrant and range through all shades of the most delicate soft colors. Pkt., 10c.

1100. ऋPETUNIA. H. A. Olds' Finest Mixed. This splendid mixture D. Will prove an agreeable surprise even to those who expect much. It
excels in richness of color, continuous bloom and large size of flowers. Pkt.. $25 \mathrm{c}$. 1102. PETUNIA. H.

1103. $\star$ PETUNIA. H. A. Rosy Morn. Compact plants bearing a profusion of beautiful flowers 116 inches in diameter, with throats of silvery-white, the rest hearily flashed with soft rosy pink. Very popular. Pkt., $15 \mathrm{c}$. ROSY MORN PETUNIA PLANTS. DOz., $40 \mathrm{c}$; 50 for $\$ 1.25$, postpaid.

1109. PETUNIA. H. A. Double Mixed. A splendid mixture of beautiful large-flowering, fringed and waved Petunias. It should be understood that only a certain percentage will come double, while the remainder will be large choice single flowers. Pkt. of 30 seeds, $25 \mathrm{c}$.

1130. PORTULACA. H. A. Double Mixed.

Moss.) Small fleshy plants, producing a bloom, no matter how dry the weather. Pkt., 10c.

1131. ŁPORTULACA. H. A. Single Mixed. Eren more beautiful than the double rariety. Pkt., 10c.

1135. PRIMULA. Large Flowering. T. (Chines

Primrose.) The best of the fringe-leared house prim roses. Mixed colors. Pkt., $20 \mathrm{c}$.

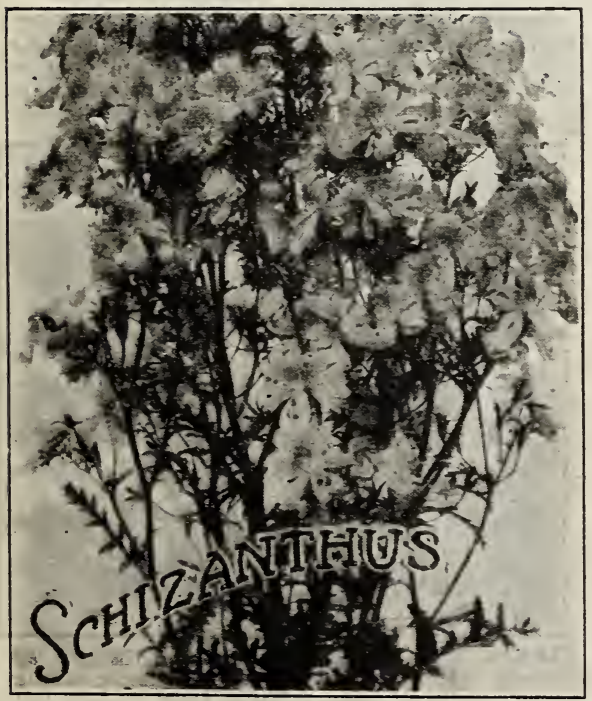

1160. SCHIZANTHUS. H. A. (Butterfly Flower.) One of the daintest of annuals and easily grown. Quickly grows into a bushy plant so completely covered with many colored flowers that the foliage is almost concealed, Plt., 10c.

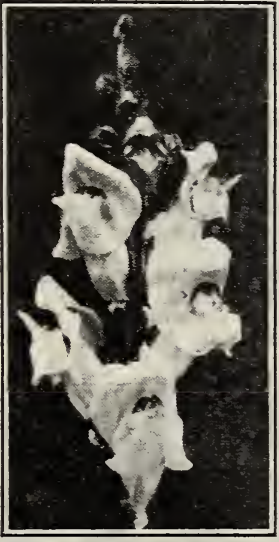

Snapdragon, Dwarf Mixed.

840. SNAPDRAGON. H. A. (Antirrhinum.) Dwarf Mixed. Snapdragons were a feature of the oldfashioned garden. Then for a time they were neglected, until when the improred new rarieties appeared, they suddenly became immensels popular again. The brilliant colored blooms remain a source of pleasure throughout the summer and fall. Pkt., 10c. SNAPDRAGON PIANTS. DWarf Mixed, Doz., 40c; 50 for $\$ 1.25$. 811. - SNAPDRAGON. H. tirrhinum.) Giant Fragrant. Pkt., $5 \mathrm{c}$. 813. - SNAPDRAGON. H. A. (Antirrhinum.) Pink Beauty. Pkt., 5c. 1140. RICINUS. H. A. (Castor
Bean.) Stately ornamental plants Bean.) Stately ornamental plants
with picturesque foliage, giring a tropical effect. Pkt., 10c; 0z., 20c.

$-69-$

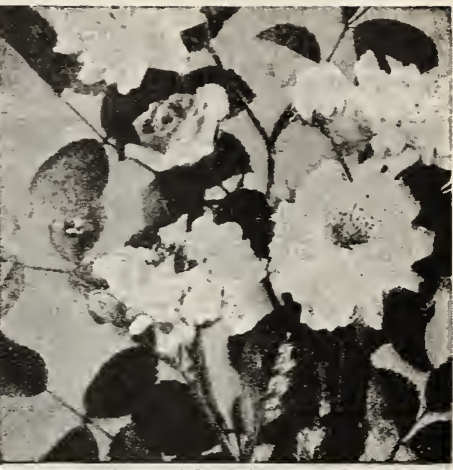

Rosa Multifiora.

1142. ROSA MULTIFLORA. P. Dwarf roses from seed. Little bushes corered with miniature

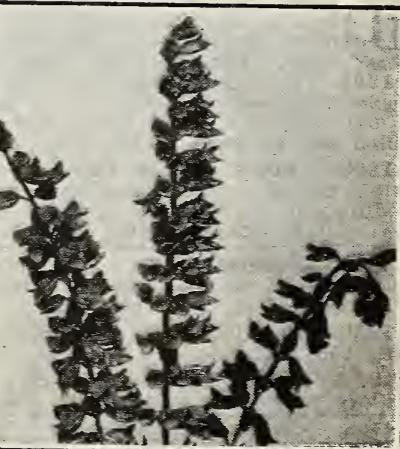

Salvia, Bright Red.

1150. SAIVIA SPIENDENS. A SALVIA PLANTS. Doz., 45c;

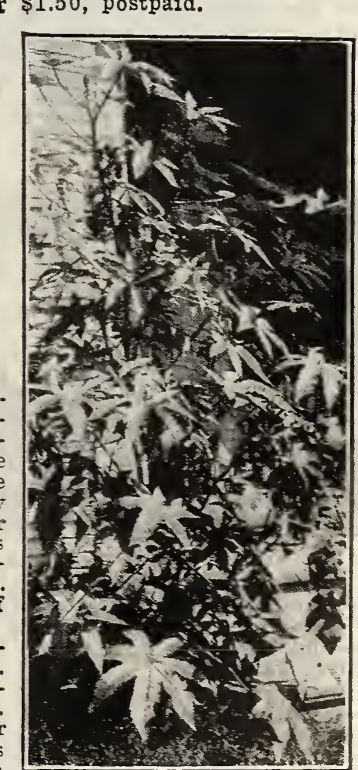

Castor Bean, 


\section{OLDS' SWEET PEAS}

Sweet Peas should be planted in trenches, 6 or 8 inches deep; but do not corer as deep as that at first. As the plants grow, fill in the trenches and cultivate frequently all the season. Plant just as early in the spring as the ground will do to work. Plant on the best soil available and fertilize frequently during the summer and be sure that the ground is kept moist. Keep the blooms picked. If you allow them to ripen seed, they will stop blooming. Keep them busy.

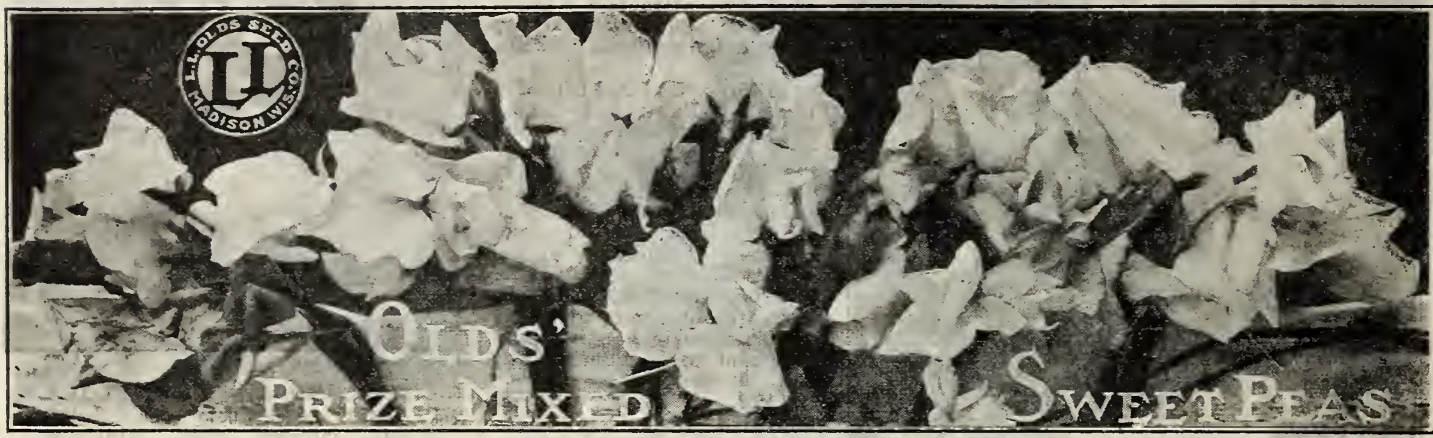

\section{BEST SWEET PEA MIXTURES}

1200. tolds' Prize Mixed. We believe this is the TI best possible mixture of the old-fashioned or grandiflora sweet peas. Many named varieties of fine
color. Pkt., 10c; oz., 20c; 1/4 lb., 50c; lb., $\$ 1.85$. 1201. Sunrise Mixed. Early-flowering Spencers only. Spencers surpass all other sweet peas-long stems, three to five blossoms on a stem; flowers very large, waved, frilled and fragrant. Pkt., 15c; oz., 40c; 1/4 lb., \$1.25. 1203. ‡Olds' Mixed Giant Spencers. A careful and well-balanced blend of the best named varieties and new seedlings of the beautiful orchid-flowered or Spencer Sweet Peas. Pkt., 10c; 0z., 20c; 1/4 lb., 50c; 1b., \$1.75.

1210. Earliest of All. This pink and white sweet pea blooms 10 days in advance of any other; highly prized by florists. Pkt., 10c; oz., 25c.

1236. Vermillion Red. Intense scarlet. Very brilliant. Pkt., 10c; oz., 25c.

1237. †Fiery Cross. Glittering orange scarlet. Won. derfully striking and beautiful. Pkt., 10c; oz., 30c.

1180. SUNFLOWER. H. A. Chrysanthemum-Flowered. Bright yellow, double flowers, resembling chrysanthe. mums. Pkt., 10c.

1185. SUNFLOWER. H. A. Mammoth Russian. Immense plants 12 feet high with single blossoms from 6 to 15 inches across. Pkt., $5 \mathrm{c}$.

969. SNOW ON THE MOUNTAIN. H. A. (Euphorbia Variegata.) A very distinct plant. Grows 2 feet high; very showy with its foliage edged. white and green. Is splendid for bouquets. Pkt., 10c.

1300. SWEET WILLIAM. H. P. Mixed. (Dianthus Barbatus.) The plants grow 18 to 24 inches high. They make excellent border plants and are fine also for bouquets. Like annual pinks, loved for its brilliant and enduring flowers. Pkt., 10c.

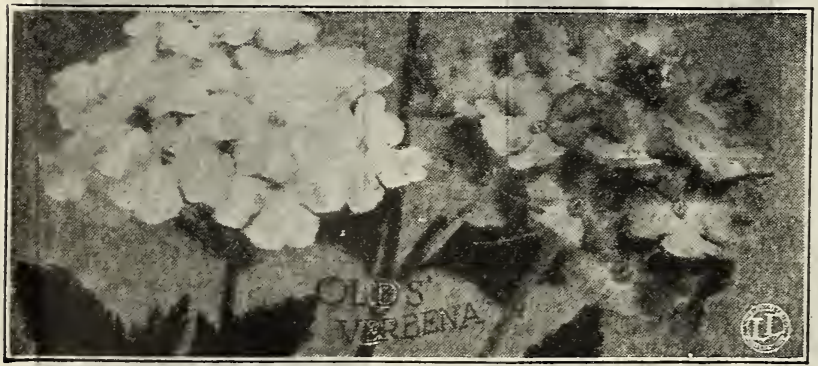

Olds' Finest Mised Verbenas.

1305. †VERBENA. H. A. Olds' Finest Mixed. A favorite old flower, one of the most popular garden annuals. Clusters of many bright colors are borne in constant suc. cession from June until frost. We offer a very choice mixture. Pkt., $15 \mathrm{c}$

1315. WALLFLOWER. H. H. P. Mixed. Half hardy perennials, bearing spikes of deliciously fragrant spring flowers. The rich red and yellow coloring of the flowers is very effective. They are easily grown and last well as cut flowers. Pkt., $10 \mathrm{c}$
TEN GHOICE NEW SPENGER VARIETIES

1211. AUSTIN FREDERICK IMPROVED. The best new lavender. Pkt., 10c; oz., 25c.

1212. CONSTANCE HINTON. The best white sweet pea for outdoor planting. Very large. Pkt., 10c; oz. 25c. 1213. DEFIANCE. Orange scarlet. A fine variety. Very large. Pkt. 15c; oz., 40c.

1214. HEA VENLY BLUE. A most beautiful soft tone of delphinium blue. Flowers of immense size, four to a stem. Pkt., 25c; oz., $75 \mathrm{c}$.

1215. MARY' PICKFORD. A famous choice new sweet pea that has already created quite a sensation. It proved a great attraction at the Los Angeles Seed Convention in 1925. The color is a dainty cream-pink lightly suffused with salmon. Most charming. Pkt., 25c; oz., 75c.

1216. MATCHLESS. Cream yellow. Large flowers, very attractive. Pkt., 10c; 0z., 25c.

1217. MISS CALIFORNIA. Another splendid new rariety. Orange salmon with cream pink. Pkt., $15 \mathrm{c}$; 0z.

1218. ROYAL PURPLE. Large, wary flowers of a rich royal purple. The best purple. Pkt., 10c; oz., 25 c. 1219. WARRIOR. Rich chocolate maroon. Large handsome flowers. Pkt., 10c; 0z., 25c.

1220. YOUTH. White, edged in a beautiful way with a delicate soft rose pink. An unusually large and fragrant sweet pea. Very desirable. Pkt., 15c; oz., 40c.

Special Offer. One pkt. each of the above 10 varieties for 90 cents. (Would cost $\$ 1.45$ purchased separately.) One ounce each, $\$ 2.50$, postpaid. $(\$ 4.05$ separately.)

\section{OLDS' ZINNIAS}

Few annuals surpass the Zinnia in general popular favor. They are rugged and strong, do well in any soil and regardless of weather, are large, showy, of many colors and shades, and bloom all summer long. Very double, large, durable and handsome. A general favorite.

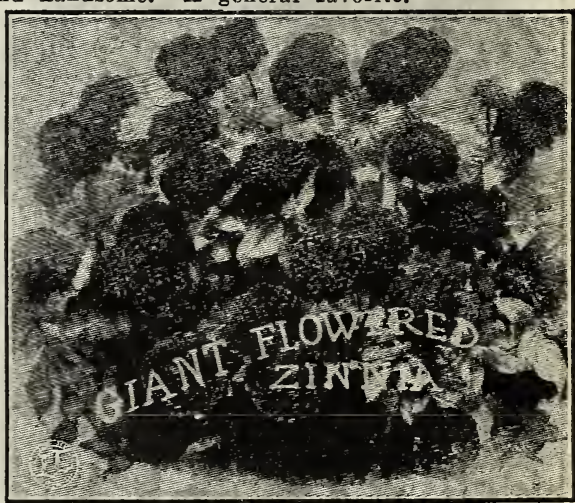

1335. ZINNIA. H. A. Giant Flowered Mixed. A mixture of named California Giant Zinnias, all large, strong. growing and of brilliant color. These grow 3 feet tall, with flowers of enormous size. Healthy, vigorous, showy, easily grown. Pkt., 10c; oz., 75c.

1329. ZINNIA. H. A. Fire King. A magnificent $\mathrm{ra-}$ riety with deep scarlet flowers. Pkt., $10 \mathrm{c}$. 
Do not overlook our Gladiolus Collection in Colors, inside of back cover.

AMERICA. One of the best. It makes a strong, healthy plant with three-foot erect flower spikes bearing many fine spreading blossoms all facing one way. The color is an exquisite soft lavender pink. We sell more bulbs of America than of any other gladiolus on our list. Bulbs, each, $5 \mathrm{c} ; 6$ for $25 \mathrm{c} ; 12$ for $45 \mathrm{c} ; 25$ for $80 \mathrm{c} ; 100$ for $\$ 3.00$, postpaid.

AMERICAN BEAUTY. (Dieners.) Brilliant American Beauty color, throat yellow, striped with ruby. The spikes bear a large number of flowers at one time, which are set close together forming an immense and magnificent bouquet. The flowers are very large, of ten measuring 5 inches across. We consider this one of the best of the new raxieties. Bulbs, each, 30c; 6 for $\$ 1.50$, postpaid.

AUGUSTA. A pleasing white, sometimes lavender feathered. Bulbs, each, 5c; 6 for $25 \mathrm{c} ; 12$ for $45 \mathrm{c} ; 25$ for $80 \mathrm{c}$, postpaid.

ANNA EBERIUS. A dark velvety purple, shading to a darker throat. A wonderful spike of close set flowers, which are large and open, forming an immense bouquet. Each, $15 \mathrm{c} ; 6$ for $70 \mathrm{c} ; 12$ for $\$ 1.35$; 25 for $\$ 2.50$, postpaid.

CHICAGO WHITE. The very earliest snow white. Six to seren flowers open at one time. Each, 10c; 6 for 50c; 12 for $90 \mathrm{c} ; 25$ for $\$ 1.50$, postpaid.

BLUE JAY. A true "Blue Jay", shade, much lighter than Baron Hulot. The well-opened flowers are carried on tall, slender stalks. In color they are a light violet blue, sometimes flaked with indigo. The deep throat is feather crimson, quickly shading into a pointed blackmaroon blotch with a great spot of cream at the tip. The cream color goes entirely through the petal, showing in the reverse. The upper center petal carries two crimson spots which show on the back as creamy white. Each, 25c; 6 for $\$ 1.25 ; 12$ for $\$ 2.25 ; 25$ for $\$ 4.25$, postpaid.

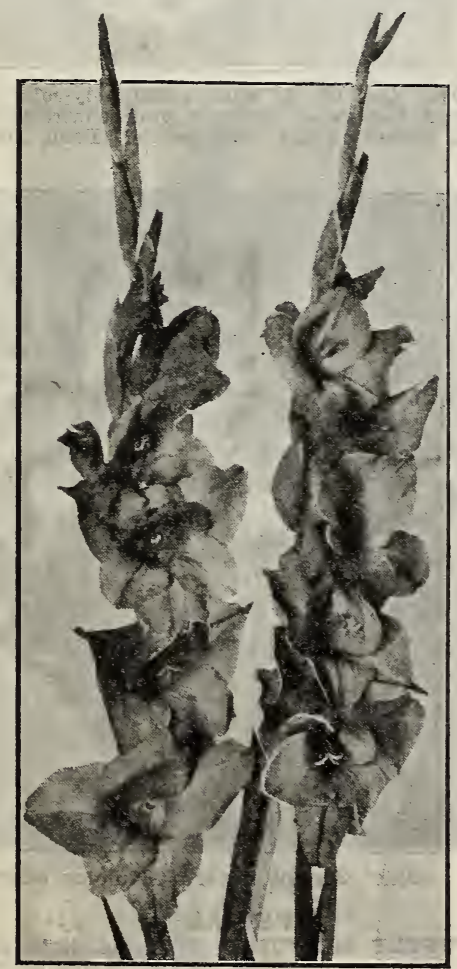

Crimson Glow.

CRIMSON GLOW. The name is the best description of its color. It has straight spikes of many flowers, which open 4 or 5 at once. This habit makes it a wonder variety for cut flowers, the bouquets lasting two weeks or more. We consider this the best red variety. Each, 15c; 6 for $70 \mathrm{c} ; 12$ for $\$ 1.35 ; 25$ for $\$ 2.50$, postpaid.

Treat your Gladiolus Bulbs with Semesan. Ask for 8page booklet. See page 28 of this catalog.
DUCHESS OF YORK. A seedling of Baron Hulot and a very great improvement over that variety; the flowers are larger und of a beautiful purplish blue color; the stems are vigorous and erect, flowers well placed on the stems: it is inclined to be rather tall but the habit of growth is straight. This is a wonderful new rariety. Each, $25 \mathrm{c} ; 3$ for $65 \mathrm{c} ; 12$ for $\$ 2.25$, postpaid.

EVELYN KIRTLAND. A beautiful shade of rose-pink darker at the edges, fading to shell pink at the center, with brilliant scarlet blotches on lower petals. Foliage not dense but supported by an erect stock; a little more than medium height; a good bloomer and many open at one time, all a glistening and sparkling lustre. Each, $15 \mathrm{c}$; 6 for $80 \mathrm{c}$; 12 for $\$ 1.40$, postpaid.

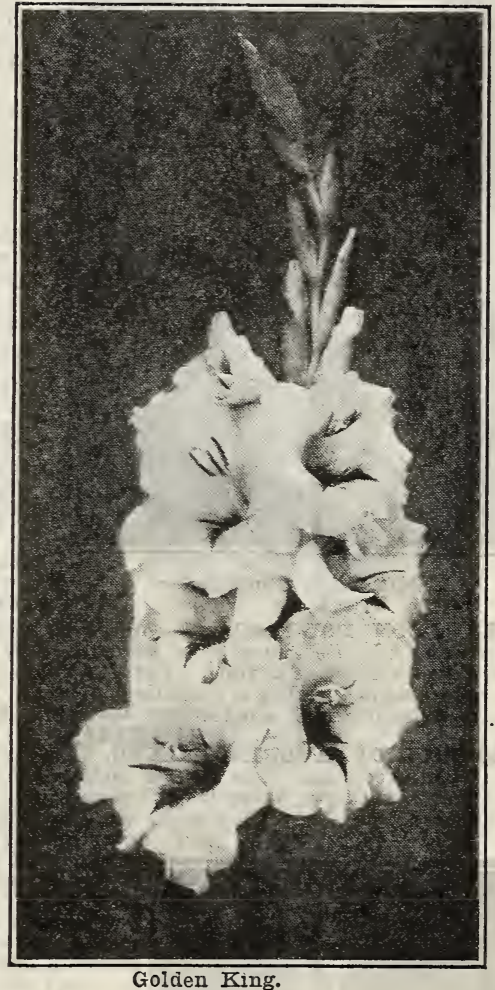

Golden King.

GOLDEN KING. Brilliant yellow with intense crimson throat blotch. Each, 10c; 6 for $50 \mathrm{c} ; 12$ for $90 \mathrm{c} ; 25$ for $\$ 1.60$, postpaid.

CONSPICUOUS. The blooms resemble large light blue pansies with yellow centers. It is large-flowering and makes a wonderful bouquet. It is well named as it is certainly conspicuous. Each, $15 \mathrm{c} ; 6$ for $70 \mathrm{c} ; 12$ for $\$ 1.35$. 25 for $\$ 2.50$, postpaid.

GOLD. This Tonderful yellow Glad has been the center of attraction at many flower shows. Pure golden yellow flowers, wide petals, recurled tips. It has as many as nine open at a time; 18 to 20 flowers on each spike. A vigorous grower, $3 \frac{1}{2}$ feet high. Blooms early and is a grand variety. Winner of first prize at Boston show in 1925. Each, $25 \mathrm{c} ; 3$ for $65 \mathrm{c}$; 12 for $\$ 2.25$, postpaid.

GOLIATH. Without doubt the best very dark-colored large-flowered Gladiolus. Dark, maroon-red with darker shading. Very large open flowers on long spikes. Flow. ers hare fine substance and arrangement. Each, 15c; 6 for $80 \mathrm{c} ; 12$ for $\$ 1.40$, postpaid.

HALLEY. Salmon-pink with carmine-marked Jellow throat: 41/2 inch blooms. Very early. Each, 10c; 6 for $50 \mathrm{c}$; 12 for $90 \mathrm{c} ; 25$ for $\$ 1.60$, postpaid.

IE MARCHAI FOCH. Rose pink, a deeper and richer color than America. A heary grower and a large-flowered variety; a fine cut flower, and the best deep-pink. Blooms very early. Each, 10c; 6 for 50c; 12 for 90c: 25 for $\$ 1.60$, postpaid.

IOVELINESS, A cream pink. Many flowers open at the same time. The flower spikes are large and broad. Its name is its best description. Each, $20 \mathrm{c} ; 6$ for $\$ 1.00$. 


\section{OLDS' GLADIOLI}

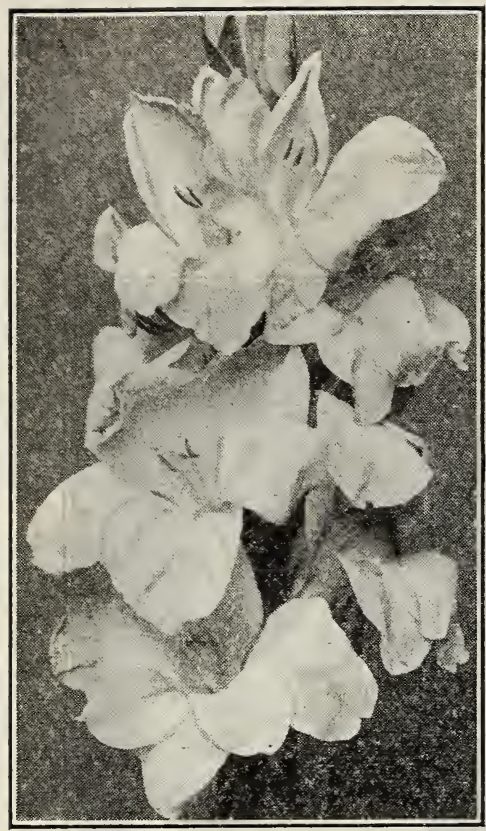

Mrs. Leon Douglas.

MARY FENNEL. The petals are a deep lilac shading to a soft primroseyellow throat. This color combination is beautiful. This is the prizewinner of all lavender varieties. Bulbs, $10 \mathrm{c}$ each; 6 for $50 \mathrm{c} ; 12$ for $90 \mathrm{c}$; 25 for $\$ 1.50$, postpaid.

MRS. FRANCIS KING. A dístinctive shade of flame pink especially beautiful under artificial light. Next to America, the leading decorative variety in the florist trade. Each, 5c; 6 for $25 \mathrm{c} ; 12$ for $15 \mathrm{c} ; 25$ for $85 \mathrm{c}$; 100 for $\$ 3.00$, postpaid.

MARY PICKFORD. An extraordinary flower and spike, of most delicate creamy white. Stem and calix also white. Sturdy, mid-season, fine blooming. A great favorite as a cut flower. Each, 20c; doz., $\$ 2.00$, postpaid.

PRINCIPINE. Intense scarlet wide-open flowers of immense size. The lower petal has a large snow-white blotch in the throat. This is the most striking of all Glads. Each 10c; 6 for $55 \mathrm{c} ; 12$ for $\$ 1.00 ; 25$ for $\$ 1.90$, postpaid.

PANAMA. A $n$ e w seedling of America resembling the parent variety in every way except that it is a much deeper and clearer pink. Tall spikes with wax-like flowers, large and wellarranged. Each, 10c; 6 for $50 c ; 12$ for $90 c ; 25$ for $\$ 1.50$, postpaid.

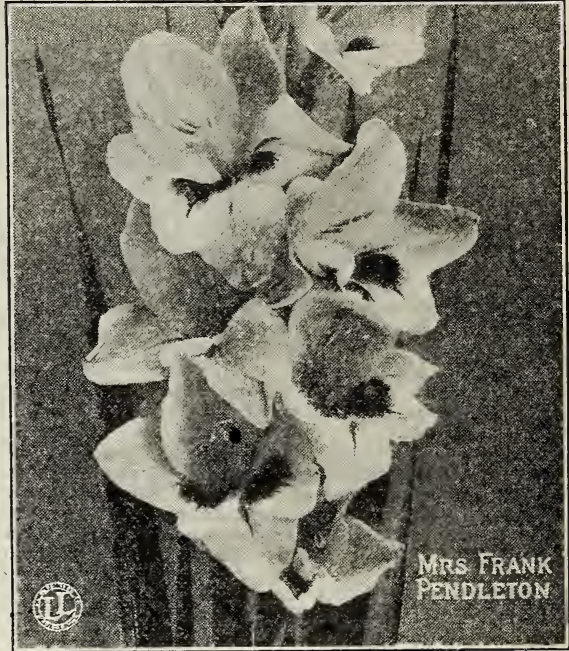

MRS. FRANK PENDIETON. One of the most exquisitely-colored kinds on our entire list. Very large flowers of delicate pink contrasting finely with the great splash of vivid scarlet on the lower petals. Each, 10c; 6 for $50 \mathrm{c}$; 12 for $90 \mathrm{c}$, postpaid.

MRS, IEON DOUGLAS. Begonia rose, delicately striped flame and scarlet, lip pale lemon speckled with ruby. Tremendously large flowers, many open at a time. Very tall, often growing 5 to 6 feet, with side shoots forming a gigantic bouquet. Considered the largest Glad. in existence and wonderfully beautiful. Each, 60c; doz., \$6.00.

PRIMULINUS HYBRIDS MPECIAL An importation from South Africa. On account of their slender and graceful habit, delicate colors and attractive shape, these new hybrids will be much appreciated for indoor decoration. They make an exceptional and striking effect

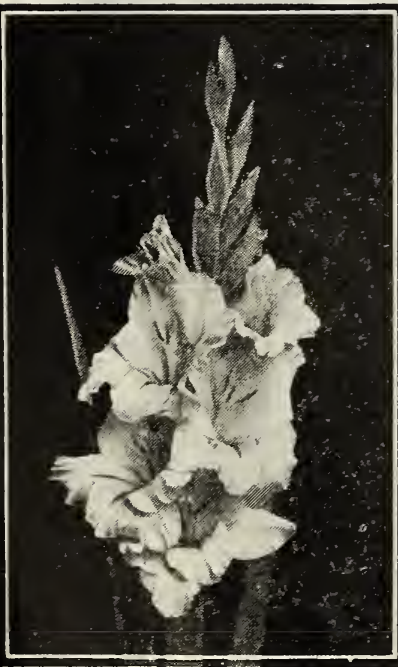

Rose Glory.

ROSE GLORY Clearest rose Clearest rose pink color with deeper throat. A very large, ruffled variety, extremely fine. Each, 20c; 6 for $\$ 1.00 ; 12$ for $\$ 1.90$, postpaid.

GLADIOLUS SEED. A very good grade of the , which will bloom most localities. From this seed you can originate new varieties, which may be named by in artificial light and range in color

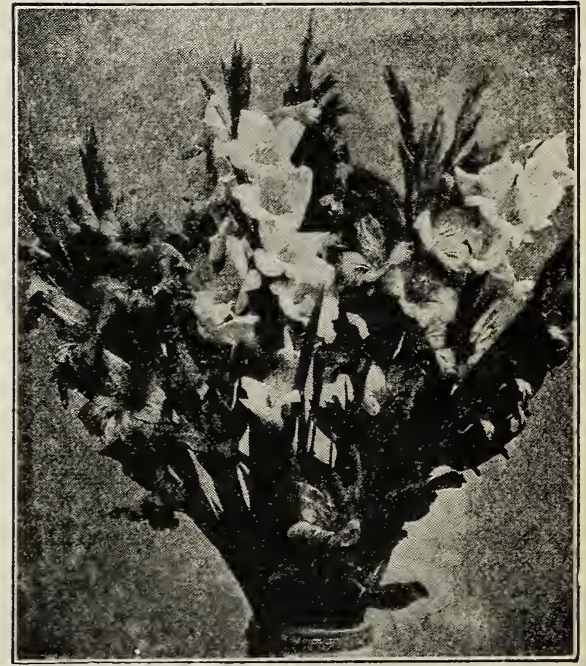

Olds' Special Superb Gladiolus Mirture.

\section{SPEGIAL} to the deepest orange and from the The flowers of pink to scarle 00 for 20 , $35 \mathrm{c}, 25$ for S 12 for $\$ 1.50$, postpaid.

with old rose Fxtra fint. 12 for $90 \mathrm{c}$

Giant glistening white, lower petals. Each 10c; 6 the $50 \mathrm{c} ; 12$ for $95 \mathrm{c} ; 25$ for $\$ 1.75$,

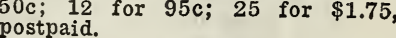
OLDS' SUPERB MIXTURE. The gladioli in this mixture are a blending of many colors, including most of our named varieties together with many new seedlings. The gladious more than any other flower will express your kind thoughts and sentiments. It is admirably suited for every occasion where flowers are used. No choicer cut flowers can be wished for, while as a showy display in the garden they are supreme. People who do not also plant mixtures-no matter how many of the named varieties they have-will miss much pleasure. Plant them generously and you, as well as your friends, will surely enjoy them. 6 for $25 \mathrm{c} ; 12$ for $40 \mathrm{c} ; 25$ for $75 \mathrm{c} ; 100$ for 


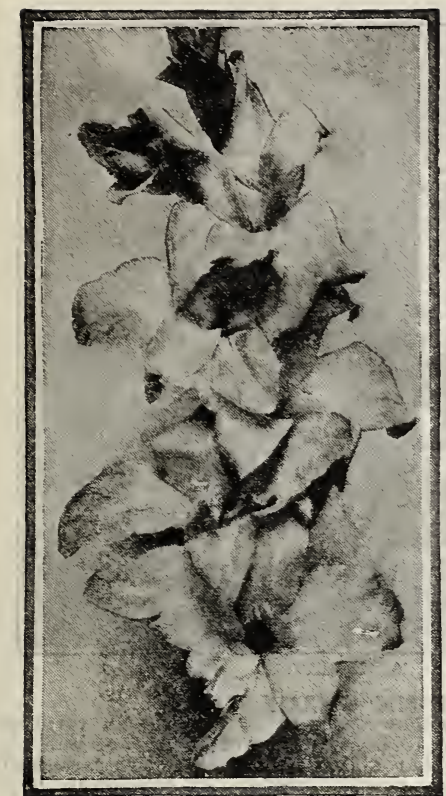

\section{OLDS' GLADIOLI}

PRINCE OF WALES. Large well-opened flowers of clearest salmon but with old-ivory throat, delicately flushed with salmon-rose. The stalks take up water well, the buds unfold to the very tips and many are open at one time. In season it is very early, blooming with Panama, Halley, and Chicago White and immediately following Wilbrink. We cannot speak too highly of this fine new gladiolus. Bulbs, $20 \mathrm{c}$ each; 6 for $\$ 1.00 ; 12$ for $\$ 1.80 ; 25$ for $\$ 3.25$.

ROSE ASH. Peculiar soft old rose tones fading to ashes of roses on the outer edges of petals; lower petals light yellow speckled with ruby; finely fluted and ruffled; wonderful in form and color. Flowers 5 inches in diameter, very strong spikes 5 to 6 feet high; flowers well set on tall, straight spikes. A magnetic flower that always attracts the eve. Medium early. Each, $15 \mathrm{c} ; 6$ for $80 \mathrm{c} ; 12$ for $\$ 1.50$, postpaid.

1910. ROSE, Pure rose-pink of extra fine shade; narrow white lines through center of lower petals. A vigorous grower very much desired for cut flowers. Second early, blooming just after Halley. Each, 15c; 3 for $40 \mathrm{c} ; 12$ for $\$ 1.45$, postpaid.

TYRIAN BEAUTY. Beautiful Prince of Wales. large flowers almost the color of American Beauty Rose. Blooming season is second early, coming a little ahead of Mrs. Francis King. The flowers open wide, five or more usually open at the same time, and as many more the second day after they are cut. It is certainly very attractive and is unexcelled as a cut flower variety. The flowers are well supported by vigorous growing stems and its habit of growth is straight and symmetrical. Each, 25c; 3 for

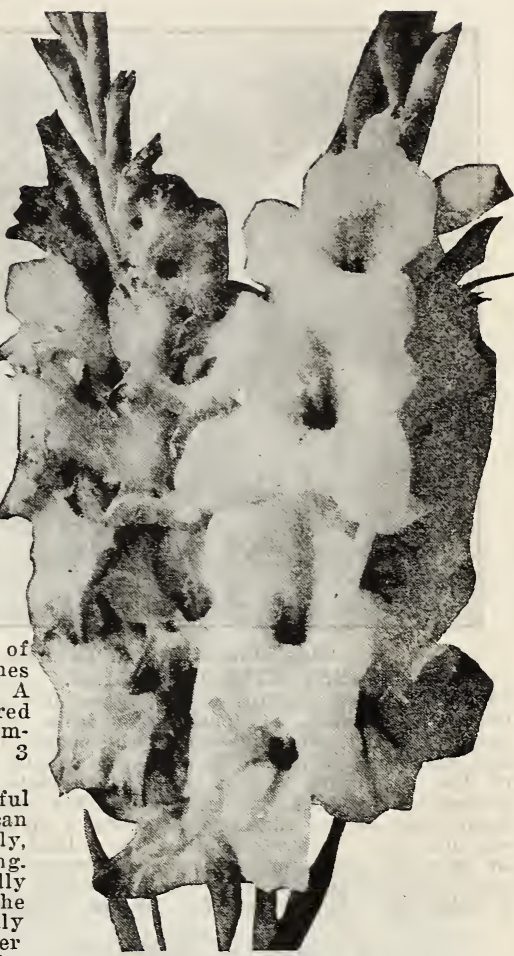

Pink Perfection and Schwaben. $60 \mathrm{c} ; 12$ for $\$ 2.25$, postpaid.

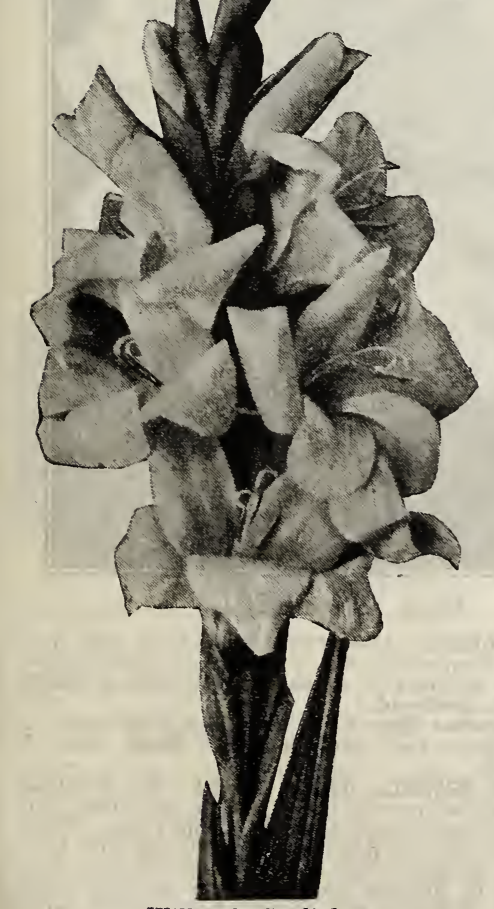

Wilbrink Gladiolus.

SCHWABEN. The largest-flowered yellow gladiolus. It opens as a pure canary yellow shading to sulphur. The throat, of brightest gold color, is marked with a small, deeply set spot of brownish maroon. Schwaben is a sturdy vig. orous grower and the luxuriant dark green foliage together with the rare color of the flowers makes it most effective for either bedding or cutting. Each, $5 \mathrm{c}$; 6 for $25 \mathrm{c} ; 12$ for $45 \mathrm{c} ; 100$ for $\$ 3.50$, postpaid.

THOMAS KENT. Cherry pink overlaid with strawberry crimson streaks on each petal. Each, 25c; 6 for $\$ 1.25$, postpaid.

WAR. Giant blood-red, shading to crimson black in throat, but without other markings. $10 \mathrm{c}$ each; 6 for $50 \mathrm{c} ; 12$ for $95 \mathrm{c} ; 25$ for $\$ 1.75$, postpaid.

WIILIE WIGMAN. Large blush-white flowers with great primrose-bordered splashes of tulip-red on lower petals. Exceptionally tall, graceful spikes. Each, $8 \mathrm{c}$; 2 for $15 \mathrm{c}$; 6 for $40 \mathrm{c}$; 12 for $75 \mathrm{c}$, postpaid.

WILBRINK. Probably the very earliest gladiolus grown; at least it is the earliest we have ever tried. The buds are lilac flushed and striped on a primrose ground. As the flowers open, the lilac changes to ight shell pink with a hint of primrose almost an "America" shade but without any tinge of lavender. The throat is deep yellow, stippled with carmine. Flowers are of largest size, many open at once. One of the finest. Bulbs, 10c each; 6 for $50 \mathrm{c} ; 12$ for $90 \mathrm{c} ; 25$ for $\$ 1.60 ; 100$ for $\$ 8.00$, postpaid.

VELVET KING. Rich shade of velvet red with darker markings. A fine bedding sort and valuable as a cut flower especially under artificial light Each 10c; 6 for $50 \mathrm{c}$; 12 for $90 \mathrm{c}$, postpaid.

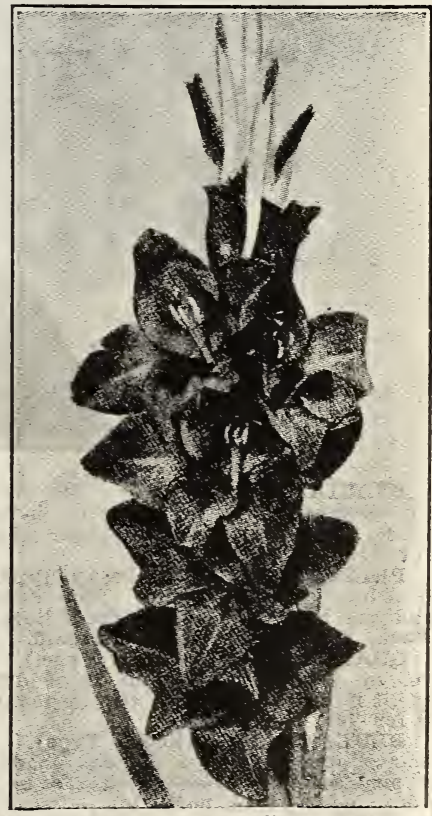

Velvet King. 


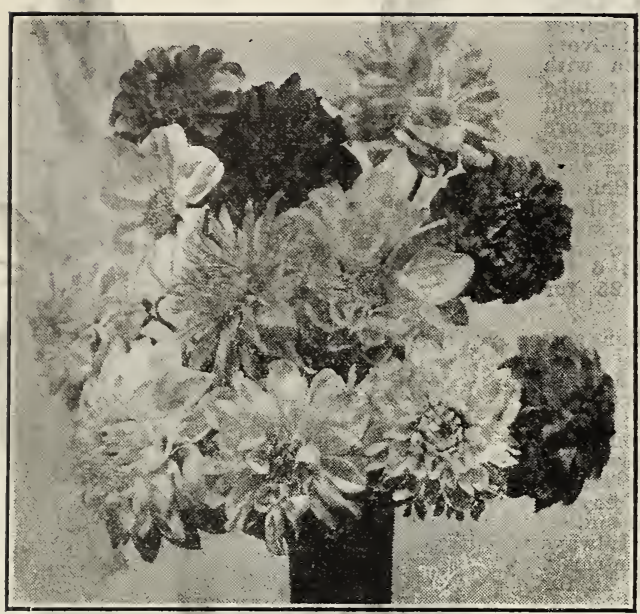

Olds' Finest Mixed Dahlias.

OLDS' FINEST MIXED DAHLIAS. A blend of choice named varieties showing every shape, size and color to be found in dahlias. Colors range from scarlet, crimson, purple and lavender through all the shades of pink, orange and yellow to white. Without seeing our mixed dahlias in the field you cannot fully appreciate the exquisite harmony of shades represented in this gorgeous mixture: Each year as we add new separate varieties of bulbs to our list these same varieties are added to our mixture so that the assortment becomes better and better each year. It is entirely made up of worthy named varieties. 3 bulbs for $45 \mathrm{c} ; 6$ for $75 \mathrm{c} ; 12$ for $\$ 1.25 ; 50$ for $\$ 4.50$.

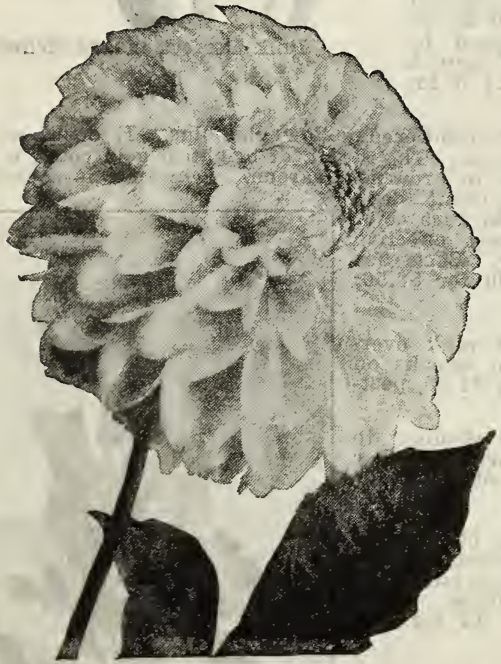

SYIVIA. (Show Type.) Thlvia. The most satisfactory flower for cutting. Very pretty, soft shell-pink with full white center. An early and profuse bloomer. Each 20c; 6 for $\$ 1.00$, postpaid.

PRINCESS MARY. (Peony Type.) A graceful flower of a lovely solferino pink. Flowers are large peony-shaped and are held erect above the foliage on long wiry stems. Each, 25c; 5 for $\$ 1.00$, postpaid.

QUAKER IADY. (Show Type.) The flowers are apricot or vellow. The plant is of dwarf habit with many small flowers, very close to the pompom type. Each, 15c; 6 for $75 \mathrm{c}$, postpaid.

BLUE OBAN. (Show Type). Fawn deepening to mauve and showing a decided shade of blue. Not really a blue but the closest approach to it in dahlias. Each, $35 \mathrm{c} ; 5$ for $\$ 1.40$, postpaid.

NOTE. Color page of Dahlias with special offer Inside Front Cover.

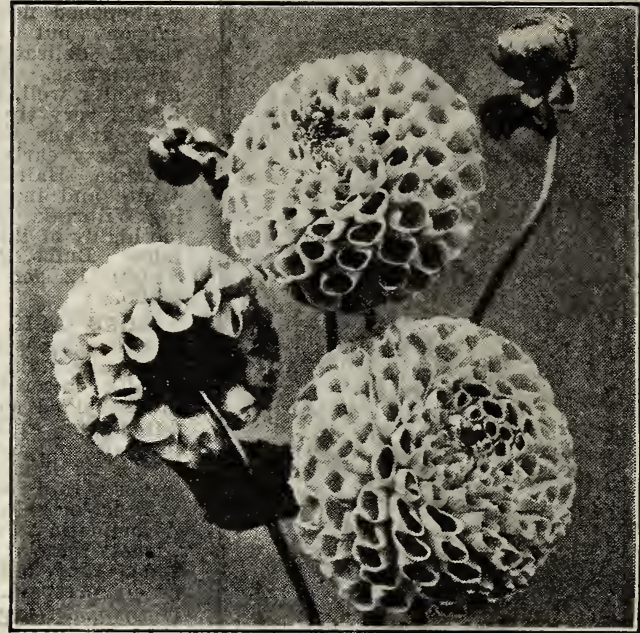

A. D. Iivoni.

A. D. LIVONI. (Show Type.) Although new varieties are being introduced each year Livoni is one of the old time tried varieties that stays. The perfect flowers with quilled petals, which nearly overlap at the ends have made this variety a great favorite. The color is rose-pink. Bulbs, each, $35 \mathrm{c} ; 5$ for $\$ 1.40$, postpaid.

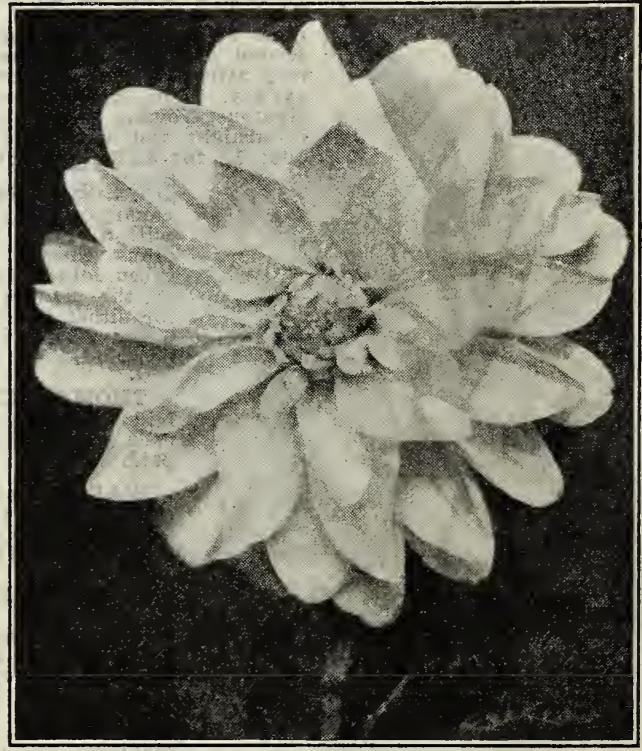

Frank A. Walker.

FRANK A. WALKER. (Decorative Type.) A new decorative variety of vigorous habit. The flowers are a charm. ing shade of deep lavender pink, having long stems. Each, $25 \mathrm{c} ; 6$ for $\$ 1.25$, postpaid.

WINSOME. (Cactus Type.) A large sea-shell pink; a very vigorous grower and free bloomer. Each, 25c; 5 for $\$ 1.00$, postpaid.

FLORAL PARK JEWEL. (Show Type.) We consider this the best red show variety. Plants are tall and straight, producing many large flowers on long stems. This makes it excellent for cut flowers. The blooms are of a purple-red shade, striped and tipped with white. You must see a plant in blossom to appreciate its wonderful and vivid beauty. Makes a fine combination planted with Princess Victoria. Each, 25c; 6 for $\$ 1.25$, postpaid. 


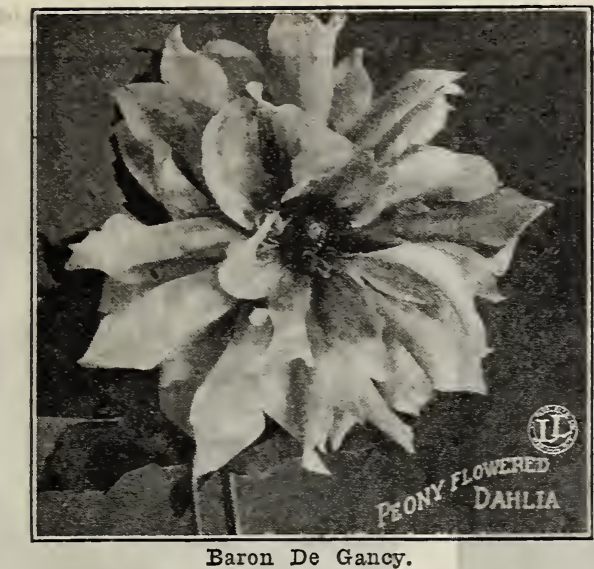

WHITE SHADES.

BARON DE GANCY. (Peony Type). The flowers are white with rellow centers. A rery good grower with long stems. It makes a good cut flower in combination with Mrs. Joe Lucas. Bulbs, each, 25c; 5 for $\$ 1.00$, postpaid. ROBERT BROOMFIELD. (Show Type). A pure white. Very large flowers. Free bloomer and a good cut-flower. Tery long stems. Each, 25c; 6 for $\$ 1.25$, postpaid.

SNOW FLAKE. (Single Type). Tery free-flowering; pure white. The finest white yet introduced. Each, 25c; 5 for $\$ 1.00$, postpaid.

MADONNA. (Decorative Type). A perfect ronder. It is beautiful in shape, an excellent cut flower varietr, and one of the most satisfactory in the garden. The flowers are borne in a miraculous profusion upon long graceful stems of wiry stiffness, making it one of the most desirable. In color a rers beautiful white. Each, 50c; $6, \$ 2.25$.

QUEEN OF HEARTS. (Cactus Type). A beautiful flower of glistening white, with upstanding petals which are tinted with canars yellow at the base. Each $20 \mathrm{c}$, 5 for $80 c$, postpaid.

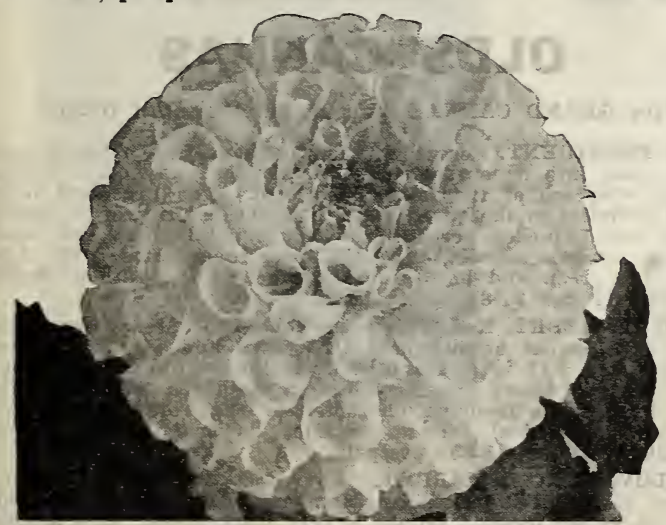

Princess Victoria. (Show Variety.)

YELLOW SHADES.

PRINCESS VICTORIA. (Show Type.) Bright canary vellow show dahlia and one of the most free flowering. Regularly quilled blooms. Each, $35 \mathrm{c} ; 5$ for $\$ 1.40$.

BRONZE BEAUTY. (Show Type.) A strong grower. Flowers are medium to large, of a beautiful golden-orange, spotted with bronze. A wonderful show dahlia. Free blooming. Each, 25c; 6 for $\$ 1.25$, postpaid.

BRITANNIA. (Cactus Type) The flowers are gold blended and shading to edge with crimson. A dwarf but rery beautiful plant. Each, 25c; 6 for $\$ 1.25$, postpaid.

BLANCHE. A beautiful single yellow and a profuse bloomer with long stems. This is a very desirable variety. We offer it this rear in order to meet the great demand for a cut flower yellow variety of dahlias. Each, $50 \mathrm{c} ; 3$ for $\$ 1.00$, postpaid.

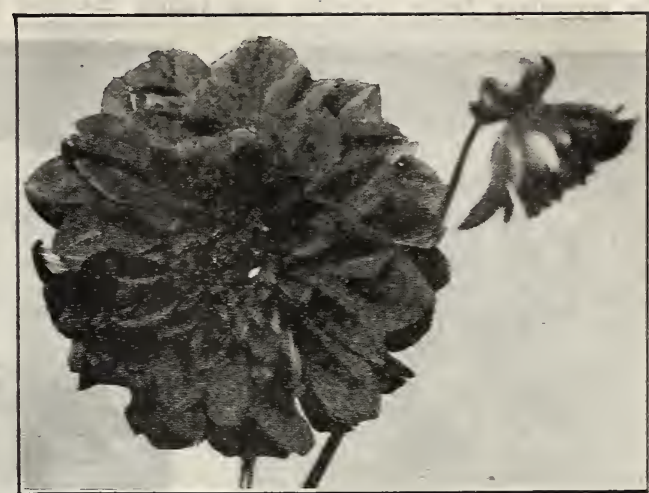

Mina Burgle.

RED SHADES.

MINA BURGLE. (Decorative Type). Beautiful deep clowing: finest crimson rariety in existence, Good for cut flowers, haring long stems. An extra free-flowering sort. Bulbs, each $25 \mathrm{c} ; 5$ for $\$ 1.00$, postpaid.

SOUVENIR DE GUSTAVE DOAZON. (Decorative Type). Orange red. It is the largest dahlia in existence. The color is a pleasing shade of orange-red. Flowers are full to the center and often measure 9 inches and over in diameter; they can be forced to measure over 12 inches. The plant is a rery tall, rigorous grower, with heary, dark, glossy, green foliage and a remarkable constitution. Tery long stems of pleasing, stiff, upright trpe. Should be in erery garden. Each, $25 \mathrm{c} ; 6$ for $\$ 1.25$.

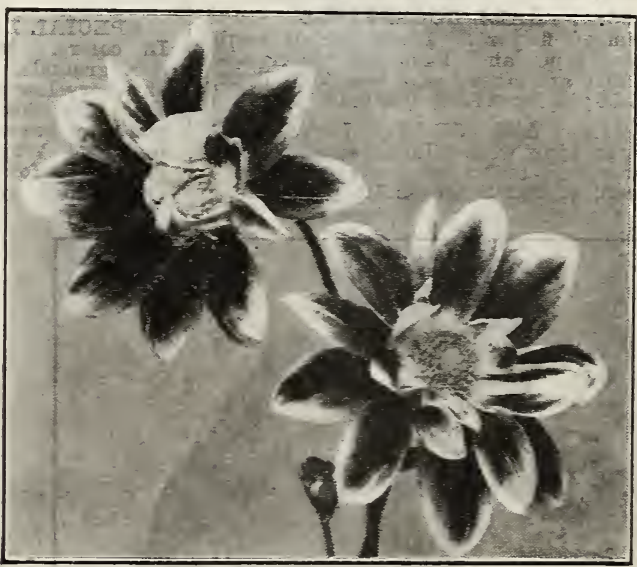

Mrs. Joe Iucas.

MRS. JOE IUCAS. (Single Type). Red with gold center. Good growth, with long stems, making it a fine cut flower. Each, 25c; 6 for $\$ 1.25$, postpaid.

J. H. JACKSON. (Cactus Type). An exceptionally satisfactorr dahlia, fine for massing or for cut flowers. Gigantic blooms of the straight petalled trpe, holding up well in water. In color it is a relvety maroon black. Each, 35c; 5 for $\$ 1.40$, postpaid.

CATHERINE DUER. (Decorative Type). A heary orower of the Decoratire trpe. Tery desirable for cut flowers on account of its long stems. One of the late sorts. Color, cherry scarlet, overlaid crimson. Each, $25 \mathrm{c} ; 6, \$ 1.00$.

JACK ROSE. (Decorative Type). A good crimson for the garden or cutting. Free blooming and the color of the well known Jack crimson rose. Each, 25c; 6 for $\$ 1.25$. MAUD ADAMS. White, overlaid with clear, delicate pink. Blooming so profusely that the plants are a reritable bank of flowers. The best white of the show dahlia class and the best for cut flowers on account of its long stems. Each, 50c; 6 for $\$ 2.25$, postpaid.

JUDGE MAREAN. This giant is produced on long. heary stems. The plant is rigorous and free blooming. The flowers are full and massire and the petals heary. A glowing salmon pink, with tints of orange and gold. Each, $\$ 1.25 ; 3$ for $\$ 3.50$, postpaid. 


\section{OLDS' PEONIES}

The percentage figure preceding each variety indicates the rating given that variety by the American Peony Society.

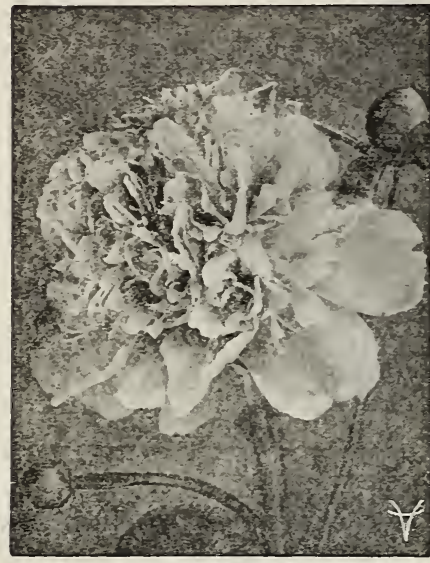

Livingstone.

$81 \%$ IIVINGSTONE. Rose type; pale lilac rose with silver tips, center petals flecked carmine; large, compact flowers. Each $75 \mathrm{c}$; 3 for $\$ 2.00$.

MAY KING. This is the old-fashioned red so much used for Decoration Day. Brilliant double red. Very early. Each, $\$ 1.00 ; 3$ for $\$ 2.70$, postpaid.

$88 \%$. KARL ROSENFIELD. Dark crimson flowers. These are of semi. rose type and have no fragrance. Plants are strong and healthy. Each, $\$ 1.50 ; 3$ for $\$ 4.00$, postpaid.

$81 \%$. ASA GRAY. Large, rose type; pink with minute carmine dots throughout ; mid-season; sturdy Each, $\$ 1.00 ; 3$ for $\$ 2.70$, postpaid.

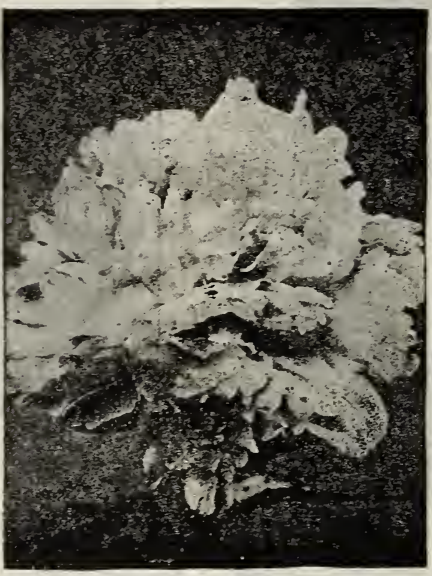

Festiva Maxima.

93\%. FESTIVA MAXIMA. Big globular masses of pure white bloom the inner petals slightly tinged with crimson. Festiva Maxima is probably the most popular of all peonies and by many considered the most nearly perfect. Each, 75c; 3 for $\$ 1.90$; postpaid.

\section{SPECIAL LANDSCAPE MIXTURE.} In colors. We grow them on our own grounds. We offer this mixture at a very low price. It will harmonize with any foundation or background you may have. Rich shades of Pink, Red and White. 3 for $85 \mathrm{c} ; 6$ for $\$ 1.50 ; 12$ for 2.80 , postpaid. Please state which colors you want.

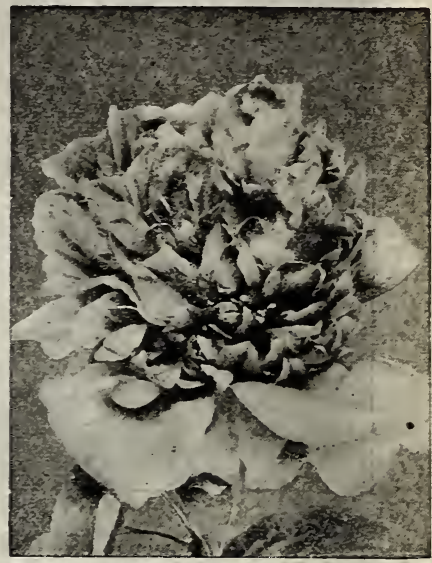

M. Jules Elie.

92\%. M. TULES ELIE. This is considered the most beautiful of all peonies. The flowers are of immense size and are globular in shape. The color is a glistening lilac-pink, shading to rose at the base. One of the best for cut flowers. Each, $\$ 1.00 ; 3$ for $\$ 2.70$, postpaid.

MIXED PEONIES. We are offering you this year something extra good in the way of mixed peonies. These are growing on our own farm and are really small clumps, they are so large. They are not carried under variety names or colors and for that reason we offer them at only 3 for $75 \mathrm{c} ; 12$ for $\$ 2.25$, postpaid. They all are good standard varieties.

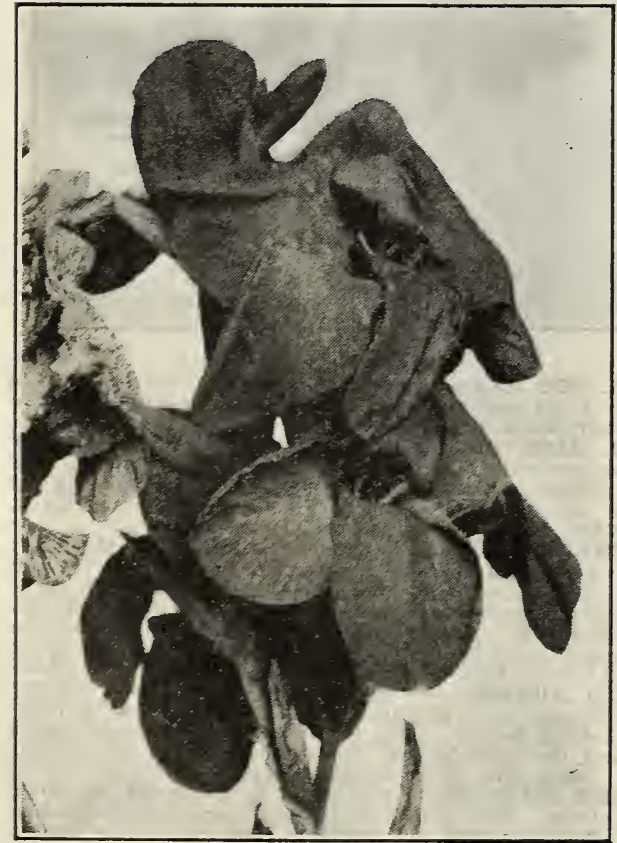

Canna, The President.

\section{OLDS' CANNAS}

Five GRAND CANNAS That Stand Above All Others.

THE PRESIDENT. Four feet. This immense new flaming scar. let has come into wider use more quickly than any other Canna. It is an offspring of the famous Firebird. The President leads the red varieties in the quality and also the quantity of its hloom. Flowers are 7 inches across: individual petals firm and longstanding; trusses standing up stiff on strong stems. The foliage is rich green and burn-proof in the hottest weather. Bulbs, $20 \mathrm{c}$ each; 12 for $\$ 1.85$, postpaid.

KING HUMBERT. Red. This remarkable Gold. Medal Canna has been the sensation of the past ten years and is the greatest favorite today. It is a cross between the orchid-flowering and the French, or Crozy type, combining the large flowers of the one with the free-blooming character of the other, with handsome, brosd, tropical foliage. Scarlet flowers; bronze leaves. Each, 20c; 12 for $\$ 1.85$, postpaid.

YELLOW KING HUMBERT. Four feet. An orchid-flowering sport of the well-known King Humbert. Has the same habi of growth as its parent; foliage a rery dark green, with flowers measuring 5 to 7 unches across; individual petals measuring to $3 \frac{112}{2}$ inches in diameter. Flower a deep rich yellow, softly spotted and blotched with bright red. Some plants occasionally give a scarlet or scarlet striped flower, which we consider an improvement rather than a detriment. Each, 20c; 12 for $\$ 1.90$, postpaid.

MRS. ALFRED CONARD. One of the rery best Cannas in commerce today The large, exquisitely shaded salmon-pink flowers are produced in great abundance on robust, upright stalks. We consider this superior to all other pink-flowered Cannas. Four feet. Each, 25c; 12 for $\$ 2.25$, postpaid.

APRICOT. Four feet. The color is a buff-yellow base orerspread with salmon-pink, making a mass effect of rich apricot. The chief characteristic of this flower is its marvelous durability, for it stands heary rain and hot sun better than any other Canna we know of. We recommend it highly. Each, $25 \mathrm{c} ; 12$ for $\$ 2.25$.

One Bulb each of above Five Cannas for 90c, postpaid.

25 , your choice of above Cannas, $\$ 3.50$, postpaid. 


\section{OLDS' IRIS}

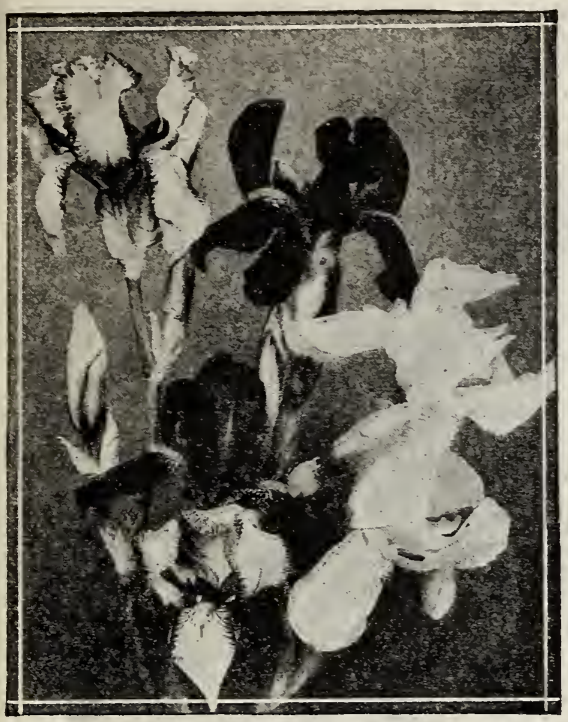

Olds' Mixed Iris.

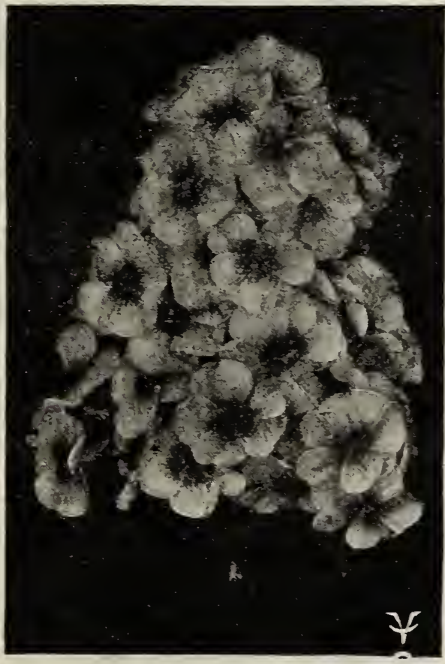

Miss Lingard Phlox.

MISS LINGARD. White with faint lilac eye. Free. blooming May to October. Choice plants, each, 30c; 4 for $\$ 1.05$.

One of our trade papers, The Florist's Review, has the following to say regarding Miss Lingard:

"PHLOX MISS LINGARD. Has rich, shiny green foliage and is a better grower than any other member of the family. No other phlox will so quickly make a large clump. Miss Lingard is the only variety that forces well. Cuttings can be planted in cold frame late in Sept., left there for the winter and planted in the spring.'

UNIVERSITY OF WISCONSIN. Bright rose carmine with light halo; a profuse bloomer, rugged grower, hardy and vigorous. Height about 3 feet. Blooms from May to October. This variety has been so popular that our supply became almost exhausted and we were compelled to withdraw it from the list last year. After propagating an additional amount we are pleased to again offer this splendid phlox. Each, 30c; 3 for $80 \mathrm{c}$; 12 for $\$ 2.90$, postpaid. aid.
MADAM CHEREAU. The stately, pure-white flowers are bordered laced with brightest blue. Large roots, $25 \mathrm{c}$ each; 4 for $90 \mathrm{c}$; 12 for postpaid

LOHENGRIN. A rare and attractive shade of maure-pink, blendWith Silver hing when the two are cut together. Each, 25c

SHFRWIN WRIGHT, A rigorous, free-blooming, golden-vellow ris, without markings or shadings. Each, 30c; 4 for $\$ 1.00$; 12 for RHEIN NIXE, A charming Iris, Rich raspberry-purple and Each 25c; 4 for $90 \mathrm{c}$; 12 for \$2.25, postpaid.

SIIVER KING. Nearly white. Each, 15c; 4 for 50c; 12 for FIAVESCENS. A delicate shade of soft rellow; one of the Each, 15c; 4 for 50c; 12 for $\$ 1.35$, postpaid.

IONORABIIIS. A golden yellow and rich mahogany brown. LENT A. WILIIAMSON. Standards erect, larender-violet, blended ith rellow toward base; falls rich royal purple; beard yellow, Has Tall and large. Splendid strong grower and free bloomer. Considered many the finest variety ever raised in America. Each, \$2.00, post-

MONSIGNOR. Rich satiny violet and purple crimson; large.

MOTHER OF PEARI. Standards and falls pale bluish larender a faint creamy undertone. Large flowers of exceptional subperfect form on well branched stems. Vigorous in growt producing its wonde1

MIXED IRIS. We have a large stock of exceptionally fine mixed They are much larger and stronger than are usually offered, hades and tints. By planting this spring, you will have blossoms season and many seasons thereafter. Hare a row of color, per. ardy and beautiful. quality: Each, 15c; 3 for $35 \mathrm{c} ; 12$

\section{OLDS' PHLOX} . 4 for $90 \mathrm{c}$, postpaid. , postpaid.

Fach, 25c; 4 for $90 \mathrm{c}$

MRS. JENKINS. A pure white. 25c; 4 for 90c, postpaid.

for $90 \mathrm{c}$, postpaid.

RYNSTROM. Deep pink, large c, postpaid.

R. Dark ind ch, 30c; 4 for $\$ 1.00$, postpaid.

IXED PHLX. An assortment of c 12 for $\$ 1.40 ; 25$ for $\$ 2.50$, post-

\section{CINNAMON VINE}

A quick growing, hardy climber, with glossy heart shaped leaves and fragrant flowers. For best effect. plant in groups of three. 3 for $45 \mathrm{c} ; 12$ for $\$ 1.60 ; 25$ for $\$ 3.00$, postpaid.

\section{TUBEROSE}

The sweetest scented flower that grows and altogeth-

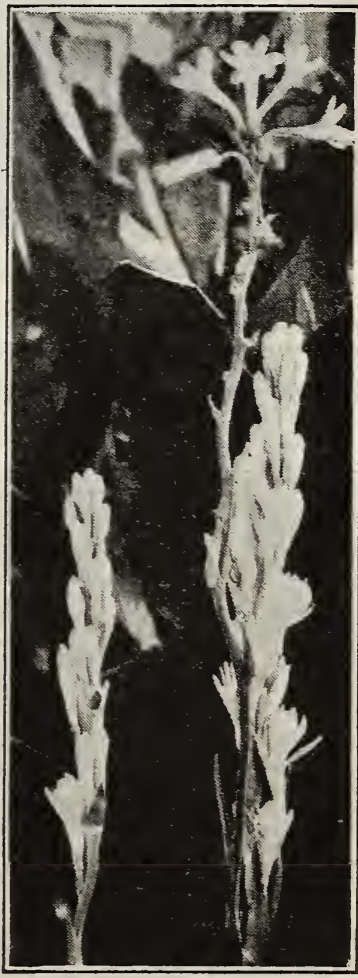

Tuberose Dwarf Pearl. er one of the most charm-

Easily grown.

DWARF PEARL. Large, double wax-like flowers of purest white: orange-blossom fragrance. Each, 10c; 6 for $45 \mathrm{c}$; 12 for $80 \mathrm{c} ; 50$ for $\$ 2.50$, postpaid.

MEXICAN. Snow-white single flowers, delightfully fragrant. Begins to bloom much earlier than the Dwarf Pearl. Each, 10c; 6 for $40 \mathrm{c} ; 12$ for $75 \mathrm{c} ; 50$ for $\$ 2.35$, postpaid. 


\section{OLDS' HARDY FLOWERING PLANTS}

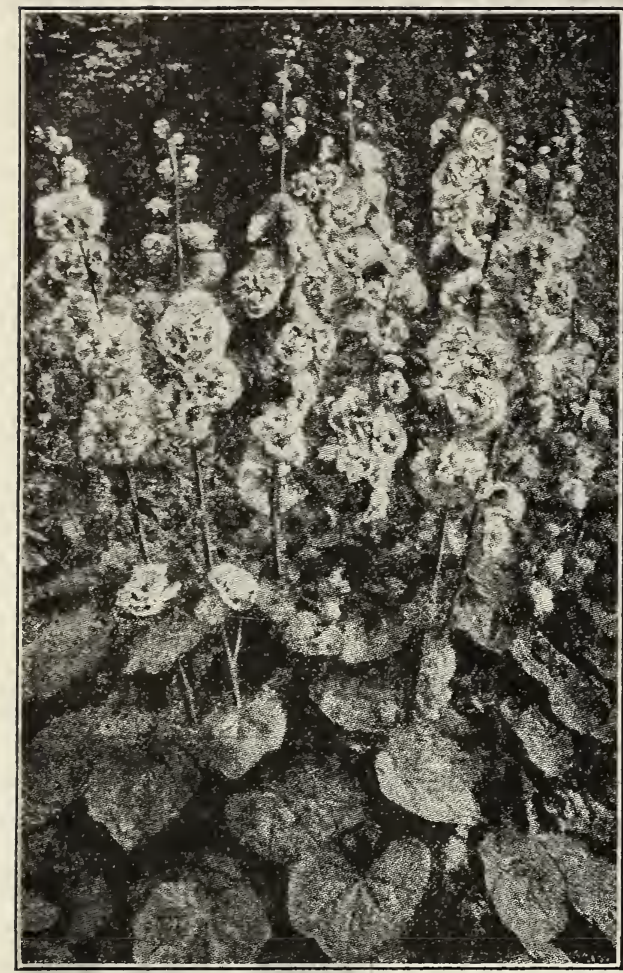

Double Mixed Hollyhock.
Every item on this page can be successfully planted in the fall, but better in the spring. Ask for our Fall Catalog if you do not receive it regularly.

BLEEDING HEAR. Long drooping racemes of heart-shaped flowers. This is the grand old plant our grandmothers raised so Trell. Each, $75 \mathrm{c} ; 4$ for
$\$ 2.50$, postpaid.

\section{AQUILEGIA.}

(Colum. bine or Honeysuckle.) One of the most graceful and dainty of hardy perennials. Flowers show shades of blue, mauve, cream, pink, red and yellow in a charm ing series of color blends. Well-rooted plants in mixed colors only. Each, 25c; 4 for $80 \mathrm{c}$, postpaid.

\section{DELPHINIUMS}

CHINESE ALBA. White. Each, $25 \mathrm{c}$; 3 for $70 \mathrm{c}$, postpaid.

BELLADONNA. L i g h t blue. Each, 25c; 3 for $70 \mathrm{c}$, postpaid.

CHINESE. Deep blue. Each, 25c; 3 for $70 \mathrm{c}$, postpaid.

ENGLISH HYBRID. Various shades of blue, from light to very dark. This is a new variety having large double flowers. Each, 30c; 3 for 85c, postpaid.

FOX GLOVE. (Digitalis.) A biennial, but renews itself from self-sown seed. Stately and dignified old-time flowers growing on tall stalks. The inflated, tubular blossoms are of very striking beauty. Each, $20 \mathrm{c} ; 4$ for $70 \mathrm{c}$, postpaid.

GAILLARDIA. (Blanket Flower.) One of the most satisfactory of all hardy perennials. In beds or in borders it produces a continuous profusion of gorgeous bloom throughout the summer and fall. The large brown center is surrounded by petals marked with concentric rings of brilliant crimson, scarlet, orange and vermilion. One of the few perennials which is always in bloom. Each, 20c; 3 for $50 \mathrm{c} ; 12$ for $\$ 1.75$, postpaid.

FALL BULBS.

Tulips, Hyacinths, Narcissus, Crocus, etc., usually known as Dutch bulbs, are listed in our Fall Catalog, ready in September Ask for a copy if you do not receive one. 8 feet high and bearing a great profusion of double golden-yellow flower's throughout August and September. 50 golden blooms may frequently be counted on one vigorous plant. Each, 15c; 4 for $50 \mathrm{c}$, postpaid.

FALSE DRAGONHEAD. (Physotegia) A handsome midsummer flowering perennial, forming large clumps 3 to 4 feet high, bearing dense spikes of beauty. Each, $20 \mathrm{c} ; 3$ for $50 \mathrm{c} ; 12$ for $\$ 1.75$, postpaid.

ORIENTAL POPPY. For a dazzling display of rich and brilliant coloring no other flower can equal the virid orange scarlets of the Oriental Poppies. Easily established if moved hefore October first and perfectly hardy. Each, 30c; 4 for $\$ 1.00$, postpaid.

GYPSOPHILA. (Baby's Breath.) Particularly prized for bouquet work, its feathery foliage and open form lighting up most pleasingly such flowers as Sweet-peas, Columbine, etc. In the garden, banks of it seem to reflect the soft white "cotton-wool" of summer clouds. Entirely hardy. Each, $20 \mathrm{c} ; 3$ for $50 \mathrm{c}$; 12 for $\$ 1.75$, postpaid.

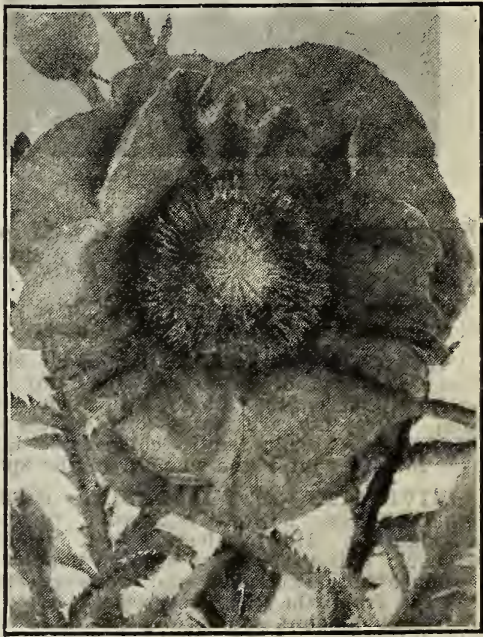

Oriental Poppy. 


\section{OLDS' HARDY FLOWERING PLANTS}

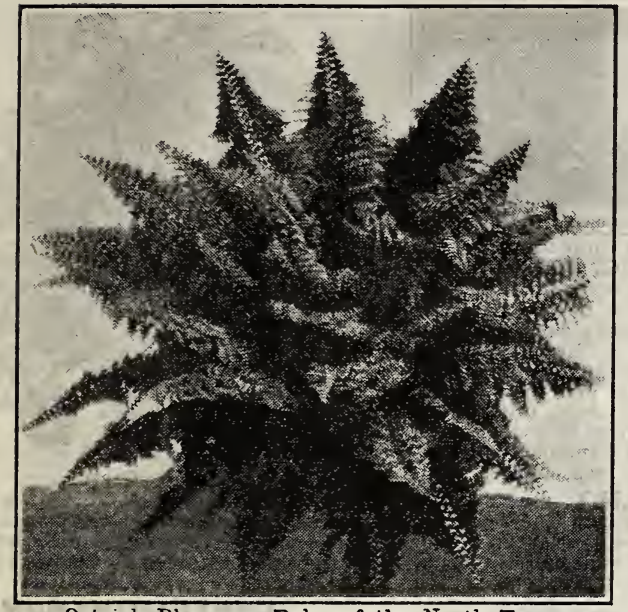

Ostrich Plume or Palm of the North Fern.

\section{HARDY FERNS}

We offer five-year-old plants direct from the far north where they grow very large and withstand any temperature. OSTRICH PLUME OR PALM OF THE NORTH. This is a fine variety; grows faster than any other kind. It often has as many as fifteen fronds, which usually attain a height of four feet; beautiful cinnamon shade. This variety does well in the open or in dry, shady places.

LADY FERN. A large, handsome fern of the woods presenting many varied forms. Smaller and of finer foliage than the Ostrich Plume.

FLOWERING FERN. This is clothed with loose wool, when unfolding its fronds, which usually attain a height of four feet; a beautiful cinnamon shade. This variety also does well in the open or dry, shady places.

Prices, all of the Hardy Ferns, 25c each; 3 for $65 \mathrm{c}$.

DIANTHUS. (Clove Pinks.) Perfectly hardy and flowering continuously from spring until late fall. Their spicy fragrance rivals their brilliant colors, varying from pure white to the richest crimson, many being beautifully striped and laced. Each, 20c; 3 for $50 \mathrm{c} ; 12$ for $\$ 1.75$, postpaid. LILY OF THE VALLEY. Sprays of drooping waxy.

\section{white Clumps. Each, 30c; 4 for $\$ 1.00$, postpaid.}

\section{HARDY DOUBLE CHRYSANTHEMUMS}

When every other flower in the garden has been killed by frost, these hardy flowers hold full sway, with a wealth of rich, oriental coloring unaffected by ordinary freezing. Everyone should have a collection of these fine plants. We offer the following colors:

old Gold, Indian Red, Light Pink and White. Each, $20 \mathrm{c} ; 4$ for $60 \mathrm{c}$, postpaid.

\section{PANSY PLANTS}

Although the pansy is a hardy perennial, it is usually treated as an annual or a biennial. We offer vigorous plants, grown from seed produced from named exhibition flowers - many of them ruffled-and showing a wonderful range of color. We selected the seed and grew the plants on our trial grounds, and we have never seen before such a glorious variety of colors, or such a blending of brilliant shades. The plants are hardy and can be planted early. They will bloom from June until frozen down in the fail. Strong, well-rooted plants, ready to bloom, postpaid: $60 \mathrm{c}$ per doz.; 50 for $\$ 2.00$.

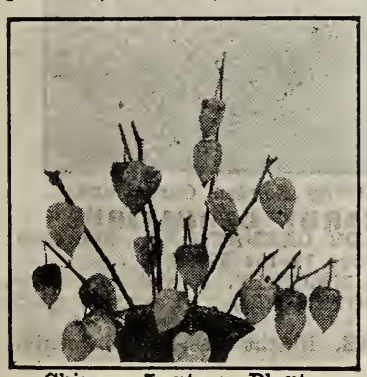

CHINESE IANTERN PLANT. A wonderful ornamental plant grown chiefly for the orangescarlet lantern-like fruits that are gathered in the fall and serve as splendid decorations at Thanksgiving and Christmas time. Very easy to grow. Good strong plants. Each, $25 \mathrm{c}$; 3 for $50 \mathrm{c} ; 12$ for $\$ 1.80$.

Plant trees this year. Prices are lower and quality better. See pages 75 and 76 .

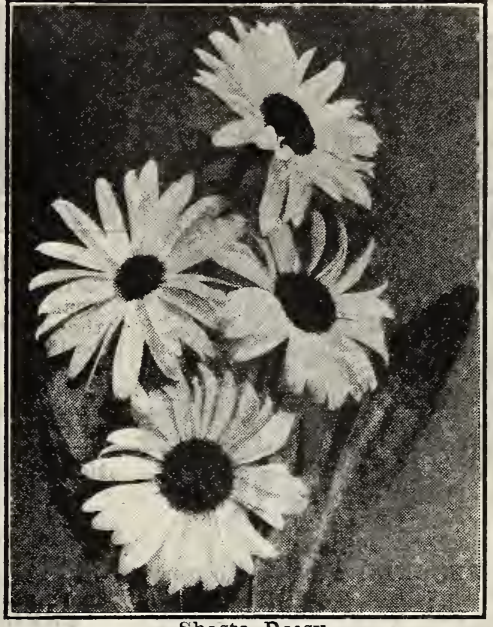

DAISIES

SHASTA. Burbank's great introduction. 4 to 5 inches across. Each, 20c; 4 for $75 \mathrm{c}$, postpaid.

MEMORIAL. In bloom by Decoration Day. Each, 20c; 4 for $75 \mathrm{c}$, postpaid.

GIANT. Great white daisies on swaying 4-foot stems. Each, 20 c; 4 for 75 c, postpaid.

PYRETHRUM. Dwarf-colored daisies, white, red and pink. Mixed colors only. Each, 25c; 3 for $70 \mathrm{c}$.

COREOPSIS. Sometimes called yellow daisy. Borne on long stems in great profusion all summer. Each, $25 \mathrm{c} ; 3$ for $70 \mathrm{c}$, postpaid.

CANTERBURY BELLS. Biennial. Great pillars of bloom in rose-pink, blue and white. Mixed colors only. Each, $25 \mathrm{c} ; 3$ for $70 \mathrm{c} ; 12$ for $\$ 2.25$, postpaid.

ACHILLEA. (The Pearl.) Pure white double flowers all summer; much prized for cutting. Each, 20c; 4 for $75 \mathrm{c}$, postpaid.

S W EE T WILLIAM. There are few plants which produce such a great mass of bloom and such a display of color as the Sweet William. Clumps, a great variety of colors. Each, 30c; 4 for $\$ 1.00$; 12 for $\$ 2.75$, postpaid.

IEMON DAY IILY. June. Clear, lemon yellow. Sweet-scented and attractive. Each, 30c; 3 for $75 \mathrm{c}$, postpaid.

DAY LIIY. (Hemerocallis.) Fulva or Tawny. These well known, oldfashioned flowers are among the more popular perennials. The plants are perfectly hardy and thrive almost anywhere.

large trumpet-shaped tall flowers of coppery orange, shaded red, are carried on stems 3 or 4 feet tall, blooming profusely in July. Each, $25 \mathrm{c}$; 3 for $60 \mathrm{c}$.

STATICE. (Latifolia.) Invaluable for cutting and floral work. Minute purplish flowers during July and August. Fine for everlasting bouquets. Each, $25 \mathrm{c} ; 3$ for $70 \mathrm{c}$, postpaid.

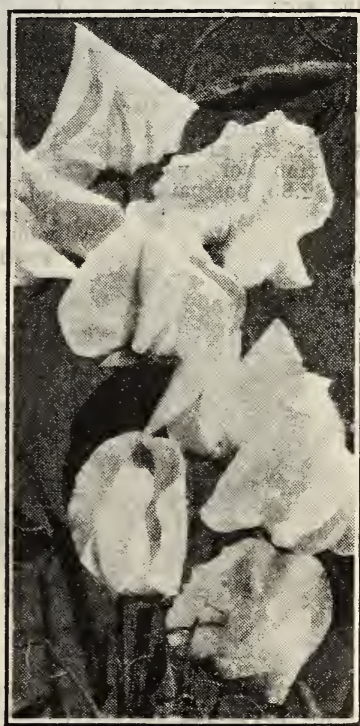

Perennial Sweet Peas.
PERENNIAI SWEET PEA. This is very similar to the annual sweet pea, but has smaller flowers. Very fine for a permanent planting to hide unsightly views or covering lattice work. Mixed colors only. Each, 35c; 4 for $\$ 1.00$, postpaid. 


\section{OLDS' HOUSE AND DECORATIVE PLANTS}

All plants offered on this and the following three pages will be sent direct from our growing station in ohio and not from Madison. We guarantee choice plants. All prices include postage.

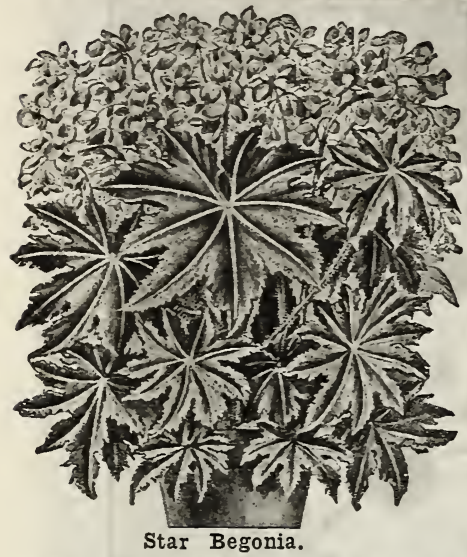

STAR BEGONIA. The leaf is very large-will average a foot or more in diameter, rich green, reddish markings; surface velvety. In bloom it is magnificent. Price, $50 \mathrm{c}$ and $75 \mathrm{c}$.

WATERMELON BEGONIA. is.

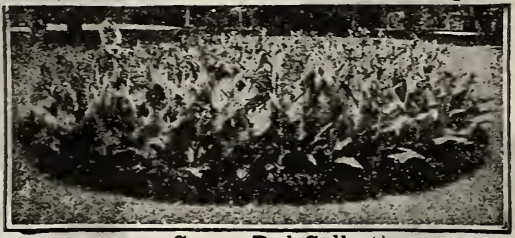

CARGE FIOWna Bed Collection. This collection will make a fine bed on your lawn, or they may be grown along the porch, banked against the side of a building, or used as a background for medium and low growing flowers and shrubbery. They will give you fresh orchid-like blooms from June until frost, and the gorgeous tropical-like foliage is unsurpassed. Price, 10 Cannas, our selection of varieties, $\$ 2.20$, postpaid.

\section{CALLA LILY}

New White Calla, Giant Godfrey.

Flowers are unusually large. The blooms are of snowy whiteness. Each, $25 \mathrm{c}$ : 3 for $65 \mathrm{c}$; extra large plants, $75 \mathrm{c}$ each, postpaid.

CHRISTMAS RED BEGONIA. Foli-

age rich, glossy green, shaded bronze; flowers red. $25 \mathrm{c}$ each, postpaid. Variegated white and green, waxy-like-frosted silver $30 \mathrm{c}$ each; 3 for 85c; 6 for $\$ 1.60 ; 12$ for $\$ 2.85$, postpaid.

\section{CUTFLOWER \\ CAR NATIONS} bouquets. $30 \mathrm{c}$ each. 30c each. PREME. $30 \mathrm{c}$ each. white, penciled scarlet. for $\$ 2.85$, postpaid.

\section{CARATIONS} matchless white. Clovescented. Ideal fo

BEACON.

Carna. tion," Rich crimson.

ENCHANTRESS SU.

salmon-p in $\mathrm{k}$

GAIETY. Glos s $30 \mathrm{c}$ each.

SPECIAI. One each of above four Carnations, postpaid $f$ o $r$ selection of varieties,

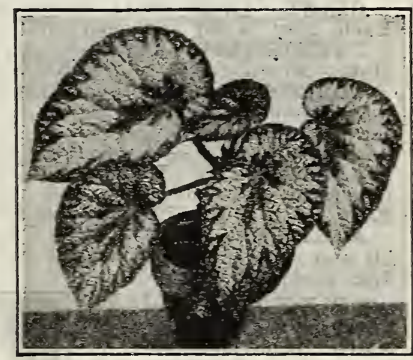

Giant Leaved Rex Begonia. GIANT PAINTED IEAF BE. GONIA. (Begonia, King or Rex.) In no other class of plants do we find the rich, metallic foliage and colors blending from bright green, silver and orange to a bright plum
color as are found here. $40 \mathrm{c}$ each, postpaid.

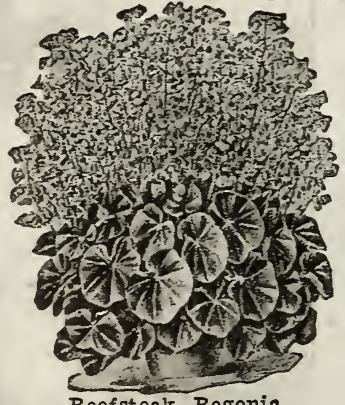

Beefsteak Begonia.

BEEFSTEAK BEGONIA. (Feastii.) Low, spreading begonia, finest pot begonia for house culture. 35c each; 3 for $\$ 1.00$; large plants, $50 \mathrm{c}$ each.

WHITE CLEMATIS. (Paniculata.) Foliage cheerful green, flowers creamy-white; fragrant. Appearing in August. Fast grower, unexcelled for porches, trellises, etc. 30c each; 3 for $85 \mathrm{c} ; 2 \cdot \mathrm{yr}$. plants, $50 \mathrm{c}$ each.

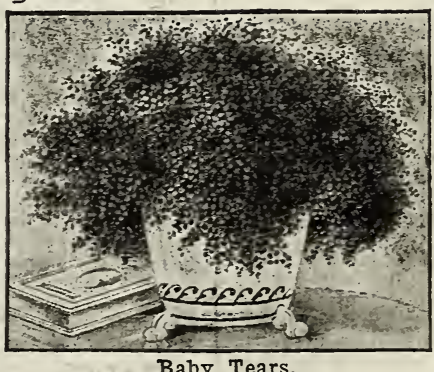

Baby Tears.

BABY TEARS. (Irish Moss.) (Helxine.) A compact, dense growing plant with miniature leares, similar to a fine moss. Of partially creeping or drooping tendency which adds much to its gracefulness. A most at tractive plant for cool, damp corners out of doors. Likes a good loamy, $\$ 1.00$.

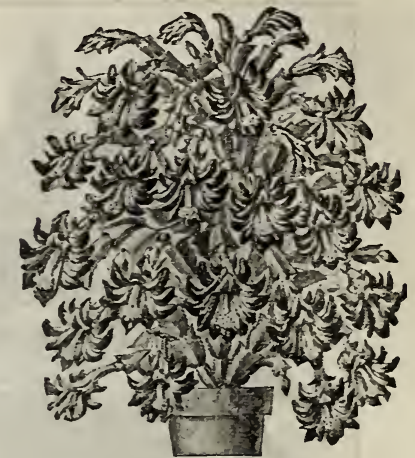

Christmas Cactus.

CHRISTMAS CACTUS. An early. flowering crimson-scarlet variety with long drooping flowers, borne in great profusion. Grows with the greatest ease. Price, 40c.

\section{GHRYSANTHEMUMS}

Price any variety, $30 \mathrm{c}$ each; 3 for $8 \mathrm{cc}$; one each of tile 4 varieties, $\$ 1.00$.

M. FROMONT. The only I, Ostrich Plume. MONDES. Pure white, strong growe. ender-pink. Good size.

PEARI OF IYONNAISE.

Bright, clear golden yellow.

SPECIAL. 12 Hardy old-Fashioned Chrysanthemums. $\$ 1.95$, postpaid.

CIIMBING F I R F CRACKER PLANT. Flowers intense scarlet shading to flame-tipped golden-yel low. $20 \mathrm{c}$ each. THORN (Euphorbia Splendens.) Foliage is bright green and the flowers are a beautiful coral-pink. Price, 30c each; 3 for $80 \mathrm{c}$.

HARDY CHRYSANTHEMUMS. One each of four $\nabla a$ red - will grow anvwhere. Postpaid $\$ 1.00 ; 10$ plants, $\$ 2.00 ; 20$ plants for $\$ 3.75$.

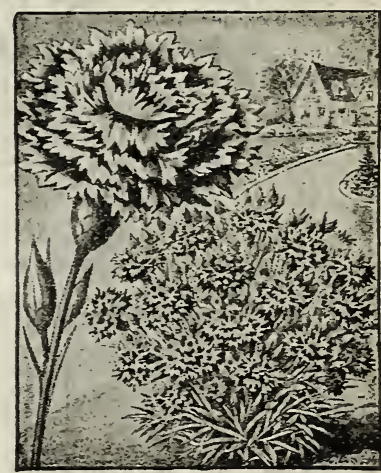

Hardy Garden Carnations.

HARDY GARNATIONS

HARDY CARNATIONS. 30c each;

3 for $85 \mathrm{c}^{\circ} 12$ for $\$ 2.65$.

HER MAJESTY. New double white. ABBOTTSFORD. Rose-red, dark ELSIE. Bright rose, maroon center. 


\section{OLDS' HOUSE AND DECORATIVE PLANTS}

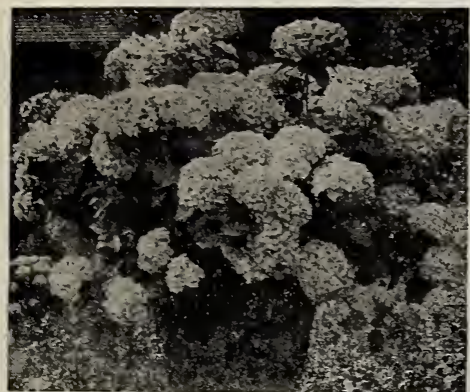

Porch Hydrangea-Bouquet Rose.

\section{FRENGH OR PORGH HYDRANGEAS}

For the Porch, Lawn and Garden. BOUQUET ROSE. Deep rosy-am. ber turning to red. Each, 35c; 3, 90c.

LA FRANCE FLOWERS. Large trusses of fringed rose. $30 \mathrm{c}$ each.

MME, MOUILIERE. Very large flowers of purest white with rosy-carmine ere. $30 \mathrm{c}$ each.

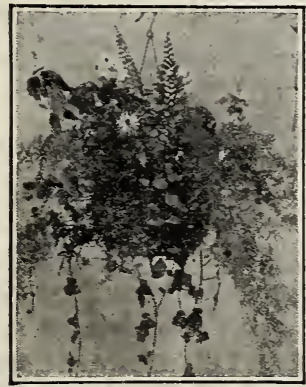

Hanging Basket Collection

\section{HANGING BASKET} COLLEGTION

No. 1. 10 plants for vase 10 to 15 inches in diameter, all different, our selection from following listCannas, Asparagus, Sprengerii, Rus. sellia, Boston Fern, Vincas, Ivy Geranium, Coleus, Double Petnuias, Sirgle Petunias, Flowering Begonias, Verbenas, Geraniums, Salvias, Dracena Indivisia, Wandering Jew, Water Ivy, Ostrich Plume Fern, Fererfew. Price, \$1.75, postpaid.

No. 2. For vase 15 to 18 inches in diameter, 18 plants we will select from such as listed abore. Price, $\$ 2.75$, postpaid.

BLUE LILY-OF-THE-NILE. (Aga. panthus Umbellatus.) Very popular. Imagine a clump of bright evergreen foliage spreading three to four feet, and surmounted by 30 to 40 spikes of bright blue flowers remaining in bloom a long period. Price, nice plants, $50 \mathrm{c}$ each; 3 for $\$ 1.25$.

STAR JASMINE. Flowers star. shaped, pure white, and fragrant. $25 \mathrm{c}$ each; 3 for $70 \mathrm{c}$. Larger plants, 50c each, postpaid.

KENTIA PAIM. The Kentia Palm represents the best of the palm family. It is a native of the Lord Howe Islands situated a few hundred miles east of Sidney, New South Wales, where it grows in luxuriance on the mountain slopes. It has the gracefulness and lightness of the Cocos but is robust in growth and heavy in foliage. As a foliage plant it cannot be excelled. Each, $75 \mathrm{c}$; extra large, $\$ 1.50$, postpaid.
HELIOTROPE MIDNIGHT. N e w riant flowered Size of foliage and flowers is doubled and plant is compact and husky Fragrant purple blossoms. $25 \mathrm{c}$ each; 3 for $65 \mathrm{c}$.

HIBISCUS PEACHBLOW. Flowers double rich clear pink, most beautiful shade. A fine pot plant for house or porch. $30 \mathrm{c}$ each; 3 for $80 \mathrm{c}$.

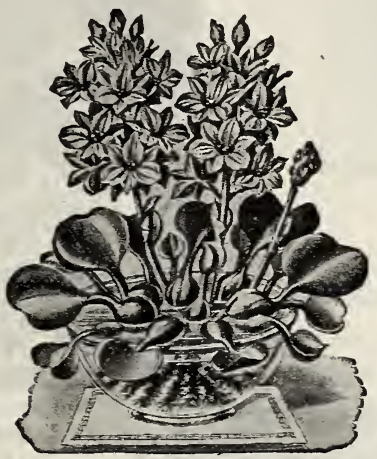

Water Hyacinth.

WATER HYACINTH. It forms a lovely rosette of its curious shining green leaves, and throws up spikes of the most exquisite flowers imaginable, resembling in form a spike of Hyacinth bloom. In color $a$ beautiful lilac-rose. Easily grown in water. $25 \mathrm{c}$ each; 3 for $70 \mathrm{c} ; 12$ for $\$ 2.50$.

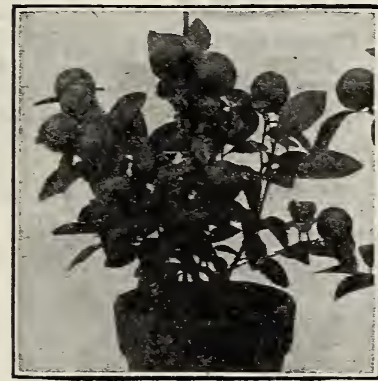

Dwarf Fruiting Orange.

FIOWERING A N D FRUITING ORANGE. A true orange, bearing masses of waxy-white, fragrant blos: soms followed by bright colored, very sweet fruit. Grown as easily as a Fern or Geranium. $30 \mathrm{c}$ each; large plants, $75 \mathrm{c}$ and $\$ 1.25$, postpaid.

\section{BEDDING LANTANAS}

ALBA PERFECTA. White.

AURORA. Flower pink.

RADIATION. Flowers crimson, changing to yellow.

JACOB SCHULZ. Beautiful dark red.

JAUNE d'OR. Variegated rose and

TETHYS. Beautiful lemon yellow.

SPECIAL, 1 each of above 7 Per. petual Blooming Lantanas for 95c, postpaid.

WEEPING IANTANA Blooms winter and summer. Violet pink. $25 \mathrm{c}$ each; 3 for $70 \mathrm{c}$, postpaid.

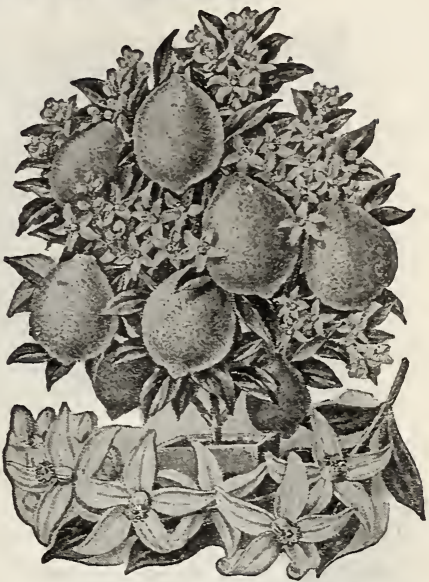

American Wonder Lemon. AMERICAN WONDER LEMON. true everbearing Lemon Fruit weigh ing over four pounds has been taken from a tree. The American Wonder Lemon excels ordinary Lemons for making pies. Of easy culture, flowering and fruiting in ordinary soil. Flowers are as fragrant as orange blossoms, which they greatly resemble. Price 30c each; larger plants, $75 \mathrm{c}$ and $\$ 1.25$ each, postpaid.

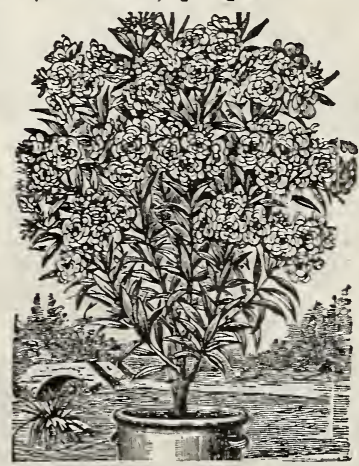

Popular Oleanders.

POPULAR OLEANDERS. T $h$ e dark, rich green foliage and beautiful blooms make it more handsome than a Palm. Can be wintered in cellar. Varieties: Pink, white, red and yellow. $35 \mathrm{c}$ each; 3 for $\$ 1.00$.

HARDY HONEYSUGKLES.

EVERGREEN. (Sweet Scented.) Snow vine with evergreen foliage. Flowers white changing to yellow. $30 \mathrm{c}$ each; 3 for $85 \mathrm{c}$; 12 for $\$ 3.00$ Larger size, $45 \mathrm{c}$ each; 3 for $\$ 1.25$.

GOLDEN LEAVED. Just like abore variety but leares beautifully netted yellow. $30 \mathrm{c}$ each; 3 for $85 \mathrm{c}$ Larger size, $45 \mathrm{c}$ each; 3 for $\$ 1.25$.

SCARLET TRUMPET, OI CORAL High climbing rariety, leares oval and oblong. Flowers scarlet. $30 \mathrm{c}$ each; 3 for $85 \mathrm{c}$. Larger size, $55 \mathrm{c}$.

DOUBLE PETUNIAS. Beautiful double fringed and frilled blooms. They are never out of flower. Colors: Purple, white, variegated, purple, mottled with white. $30 \mathrm{c}$ each.

SINGLE PETUNIAS. Always popular. Plants in mixed colors from an exceptionally fine strain. $20 \mathrm{c}$ each 3 for $45 \mathrm{c} ; 12$ for $\$ 1.50$, postpaid. 


\section{OLDS' HOUSE AND DECORATIVE PLANTS}

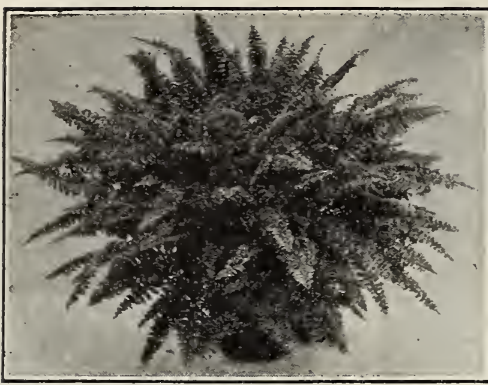

Popular Boston Fern. FER NS

Price, 30c each; larger size, 50c; extra large size,

$75 \mathrm{c}$ and $\$ 1.00$, postpaid.

CAMPACTA. The ostrich plume fern. Fronds often ver 8 inches wide.

BOSTON. Long drooping fronds. A fern that looks ell anywhere.

Dense massive fronds; erect in growth. Exceedingly graceful. glumosus.) Fronds bright green, gracefully arched, finely markable. $30 \mathrm{c}$ each; 3 for $85 \mathrm{c}$; larger plants, $60 \mathrm{c}$.

SILVER FERN. A very showy fern with variegated foliage. Fronds large, light green with broad band of silver-white down the center of each. Very distinctive. Should plants. $40 \mathrm{c}$ each.

MAIDEN HAIR FERN. Long graceful fronds with the ends developed into bunchy tasseled heads. A distinct and lovely variety. $35 \mathrm{c}$ each.

MOSŞ FERN. Beautiful upright-growing IIoss, numerous feathery stems. 1.2 to 18 inch-

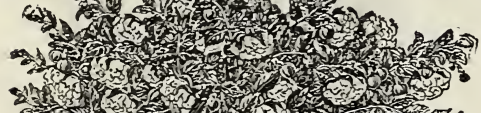
(1) .

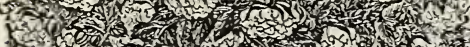
30 . Fin ascing 50 ?

Mammoth Double Fuchsia. BEST FUCHSIAS

Price: $25 \mathrm{c}$ each; 3 for $65 \mathrm{c}$, postpaid.

\section{PHENOMENAI, Bright scarlet}

flowers with rich purple corolla.

GIANT BEAUTY. Sepals carmine and corolla deep lilac.

GLOIRE DES MARCHES. Double

scarlet and white. in length, tube and sepals bright carmin

BIACK PRINCE. Flowers carmine rose. extra large.

SPECIAI OFFER. One each of above five everblooming Fuchsiasnever out of flower.

Best year-around pot plant, $\$ 1.00$. IHACE FERN. (Asparagus be in every collection of house es in height. $30 \mathrm{c}$ each; 3 for 80c. - 18 ह

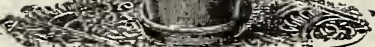

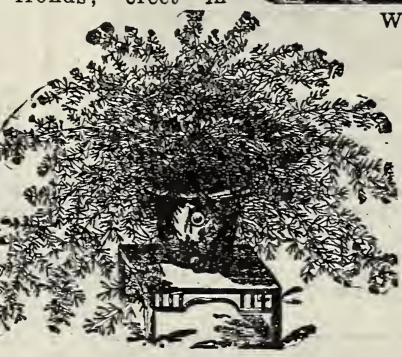

Feather Fern.

EATHER FERN.

(Asparagus dense glossy-green graceful droopbranches. Can be grown as a vase, eet long. 25c each; larger plants, $0 c$ and $75 \mathrm{c}$, postpaid.

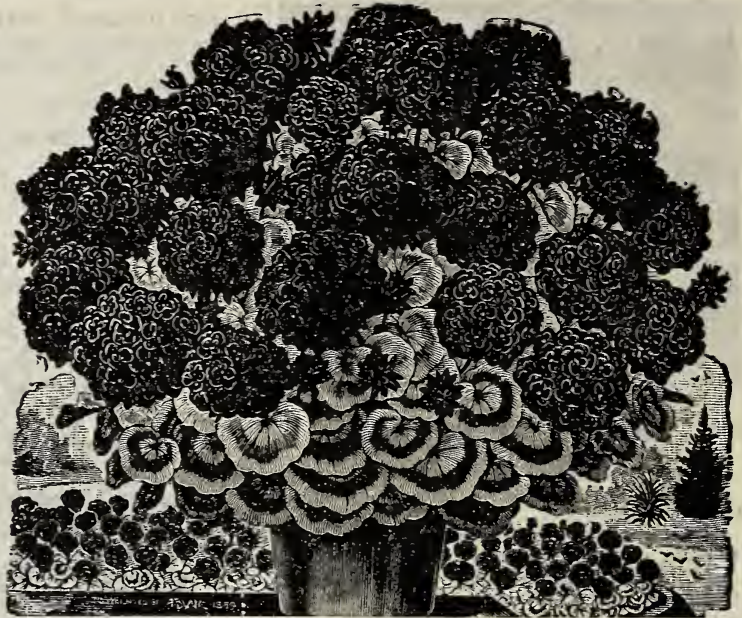

Wonderful Double Geranium "Radio Red."

BRILLIANT-FLOWERED GERANIUMS

RADIO RED. Bright dazzling red.

APPLE BLOSSOM. Salmon-rose.

MASTERPIECE. Velvety-purple.

DAYBREAK. Deep, clear, pink.

MORNING GLOW. Soft salmon rose.

GYPSY QUEEN. Brilliant apricot.

Each, 25c; 6 for $\$ 1.25$, postpaid.

FANGY-LEAVED GERANIUMS

GOLDEN TRI-COLOR. Leaves bronze belted with crimson, orange flowers. $35 \mathrm{c}$ each.

SILVER-ILEAVED S. A. NUTT. Beautiful silver leaved. Flowers dark red. $35 \mathrm{c} \mathrm{each}$.

HAPPY THOUGHT GERANIUMS, D a $\mathrm{r} \mathrm{k}$ foliage. Flower scarlet. $30 \mathrm{c}$ each; 3 for $80 \mathrm{c}$.

SWEET-SGENTED GERANIUMS

Price: $30 \mathrm{c}$ each; 3 for $80 \mathrm{c} ; 12$ for $\$ 2.65$.

BALM. Lilac colored flowers.

IADY MARY. Nutmeg-scented; pink flowers.

CUT-IEAF ROSE. Used in perfumes.

IVY LEAVED GERANIUMS. Trailing Geranium, resembling Iry, Colors: Red, white, pink. $30 \mathrm{c}$ each; 1 each of the three colors, $80 \mathrm{c}$.

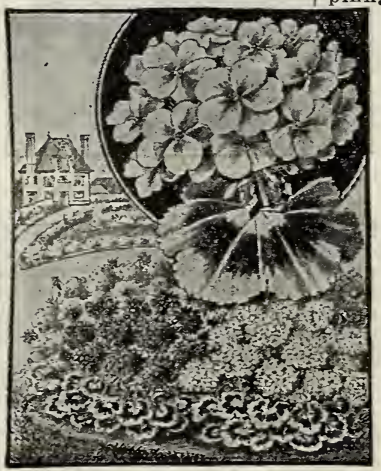

Double Bedding Geraniums.

FIREBALI. Dark red. 25c each. JEAN BIAUD. Rosy pink. Giant. $20 \mathrm{c}$ each, postpaid.

IA FAVORITE. Bushy, white blooms. $20 \mathrm{c}$ each.

MRS. LAWRENCE. Satiny salmon pink, 20c each.

CARDINAI. Dazzling scarlet. 20c. FRANCES WILLARD. Exquisite pearl pink, 20c each.

SPECIAI. Any 3 of above Geraniums, 55c; the six for $\$ 1.05$, postpaid.

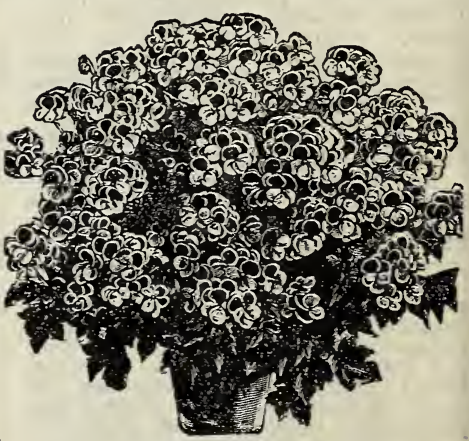

Pansy Geranium.

PANSY GERANIUM. Mrs. Iayal. Mrs. Layal Pansy Geranium (or Pelargoinium) bears flowers the markings of which are most extraordinary -light pink, white, dark purple, black, etc., also rivaling the Pansy in neatness of flower. The plant is of the easiest growth and is literally covered with flowers all the time. Price, $45 \mathrm{c} ; 3$ for $\$ 1.25$, postpaid. FIRECRACKER PIANT, WEEPING. Of slender, arching, drooping habit, literally covered with brilliant coral-red buds and flowers. 30c each, postpaid. 


\section{OLDS' ROSES AND DECORATIVE PLANTS}

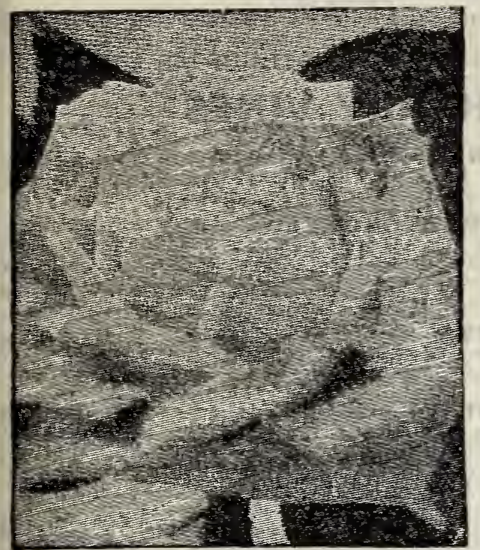

Rose, White American Beauty.

\section{ROSES THAT BLOOM ALL} SUMMER.

IA FRANCE. Exquisite soft pink, shaded silvery rose. 1-year, $30 \mathrm{c}$ each; 3 for $70 \mathrm{c} ; 2$-year, $70 \mathrm{c} ; 3$ for $\$ 2.00$.

PINK KILTARNEY. Brilliant and sparkling shell pink. 1-year, 30c each 3 for $80 \mathrm{c}$; 2-year, $70 \mathrm{c} ; 3$ for $\$ 2.00$.

PERLE DES JARDINS. Clear golden yellow. Tery fragrant. 1-year, $30 \mathrm{c}$ each 3 for $85 \mathrm{c} ; 2$-year, $70 \mathrm{c} ; 3$ for $\$ 2.00$.

FRANCIS SCOTT KEY. Crimson scar let. Growth strong, vigorous and free branching. 1-year, $25 \mathrm{c}$ each; 3 for $80 \mathrm{c}$; 2 -year, 70c; 3 for $\$ 2.00$

ANGELUS. Snowy white. Large blooms. Strikingly beautiful. 1-year, RED RADIANCE. Carmine red. Free flowering. 1-year, $30 \mathrm{c}$ each; 3 for $85 \mathrm{c}$; 2 -year, $70 \mathrm{c} ; 3$ for $\$ 2.00$.

MME. BUTTERFLY. Apricot shaded gold. Flowers very double. Unsurpassed. 1-year, 30c each;

SPECIAL OFFER. One each of the seven "Roses that bloom all summer."
HARDY CLIMBING ROSES.

One-year plants, $30 \mathrm{c}$ each; 3 for 60c; 2 -year, $60 \mathrm{c}$ each; 3 for $\$ 1.70$, postpaid.

CLIMBING AMERICAN BEAUTY. Same as Amerian Beauty with climbing habit.

BLUE RAMBLER. Flowers metallic blue, borne in

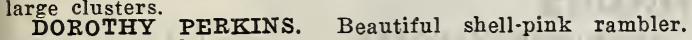
Sweetly scented.

SHOWER OF GOLD. Deep golden yellow; beautiful foliage.

\section{HARDY JUNE BLOOMING ROSES.}

One-7ear plants, $75 \mathrm{c} ; 3$ for $\$ 2.15$, postpaid.

WHITE AMERICAN BEAUTY. The best snow-white Rose we have.

PAUL NEYRON. A beautiful deep rose pink.

The

PRINCE CAMILLE DE ROHAN. Dark, velvety crim-

GLOIRE LYONNAISE.

Sulphur sellow. A grand Rose.
LEMON VERBENA.

The most fragrant foliage of any plant grown. Fragrance of the lemon. One plant will scent the whole garden: Rapid grower; white flowers. Winters in the cellar. $35 \mathrm{c}$ each; 3 for $\$ 1.00$, postpaid.

WANDERING JEW. Foliage variegated purple and scarlet; $20 \mathrm{c}$ each; 3 for $50 \mathrm{c}$, postpaid.

TRAILING VINCA. (Variegated Periwinkle.) Tariegated trailing vine for hanging baskets and vases. Flowers blue. Popular. 20c each; 3 for $50 \mathrm{c} ; 12$ for $\$ 1.75$. T E R N PLANT. (Physalis.) Wh it e. blossoms followed by orange-scarlet 1 a $n$ tern-like fruit. A novel indoor winter decoration. 30c each, postpaid.

SALVIA. (Flowering or

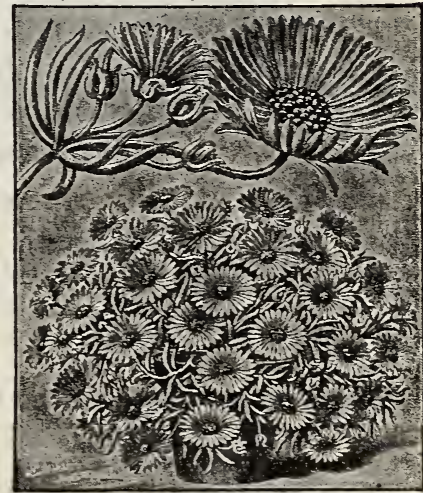
bedding and porch box plant. Following varieties: Violet blue, white, spotted, giant red and scarlet. $20 \mathrm{c}$ each; 3 for $55 \mathrm{c} ; \$ 2.00$ per

\section{BABY PRIMROSE}

It forms a dense rosette of fleshy leaves. Dainty flowers of rose-lilac with
eye of pure gold. Produces an abundance of flowers. Each, $35 \mathrm{c} ; 3$ for $\$ 1.00$, postpaid. FANCY COLEUS, CHRISTMAS GEM. Leares bright carmine, shading to deep maroon, marking yellow and green, the whole leaf a rich velvety lustre. Leaves sometimes over 12 inches long. $25 \mathrm{c}$ each; 3 for $70 \mathrm{c}$

CÓLEUS. Trailing $\mathrm{Q}$ u e e $\mathrm{n}$. Leaves cherry-red, bordered deep maroon. Price, 20c each; 3 for $50 \mathrm{c}$.

Free-blooming Wax Plant. WAX PLANT. (Desert Plant.) Mesembryanthemum. Suitable for hang. ing baskets; also for a pot plant. Free flowering; bushy wax-like appearance. Beautiful pink flowers. 25c each; 3

for $70 \mathrm{c}$, postpaid.

BIG BARGAINS IN

\section{PLANTS.}

F 11. 6 Charming Everblooming Roses, all choice kinds and free bloomers; all different, 95c, postpaid.

F 12. 2 Tea Roses, 2 Hardy Roses, 2 Climb. ing Roses, 95c.

F 14. 4 Superb Hardy Roses and 4 fine Hardy Climbing Roses, $\$ 1.30$.

Rectangular Bed of Geraniums.

RECTANGULAR BED NO, 14. Rectangular bed $2 \times 3$ feet, 14 Dusty Millers for border, 6 red or pink Geraniums for center (20 plants in all). Price, $\$ 2.80$, postpaid.

RECTANGULAR BED NO. 15. Rectangular bed $3 \times 5$ feet, 18 Dusty Mrillers for border, 15 all red or all pink Geraniums for center ( 33 plants in all). Price, $\$ 4.60$, postpajd.
15. 6 Prize Winning Chrysanthemums, all different, 95c.

F 16. 8 Choice Single and Double Geraniums, $\$ 1.30$. 


\section{OLDS' VINES AND SHRUBS}

"Planting that Nursery Stock." A most valuable booklet, complete and concise, by Professors James G. Moore and Franz A. Aust of the Horticultural Dept., University of Wisconsin. Postpaid, 10c, or free on request with nursery order. PRICES, ALI SHRUBS AND VINES, POSTPAID: EACH, 40c; 10 FOR \$3.25 UNLESS OTHERWISE PRICED.

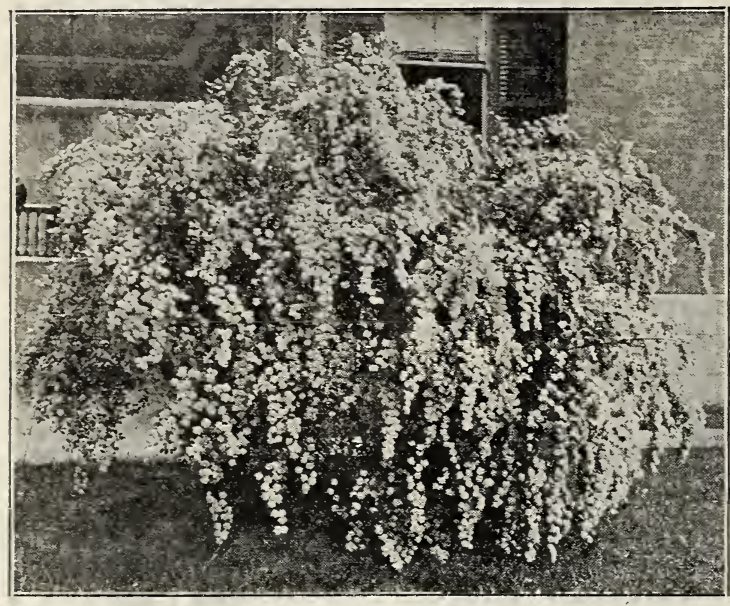

Spirea Van Houttei.

\section{HARDY VINES}

VIRGINIA GREEPER. A hardy rapid-growing climb. er with luxuriant foliage which changes in autumn to brilliant orange and crimson.

SCARLET HONEYSUGKLE, A tall sturdy climber, especially suitable for a north position. The bluish green foliage covers well and the plant blooms from midsummer until very late in the fall. The flowers are trumpet-shaped and of a bright vermilion color with a golden yellow center.

BOSTON IVY. (Veitchi). The well known vine for covering brick and stone work. A much better climber than Engelmanii and with finer foliage.

ENGELMANII IVY. It has a foliage which turns to bright crimson in the fall. It also has the clinging habit of growth and may be planted to climb smooth surfaces: hardier than the Boston Iry and will do well in any situation.

WISTERIA. This is the famous Purple Wisteria of Japan. By close pruning it may be grown in tree form.

HALL'S HONEYSUGKLE. A tall climber with dark droping foliage and fragrant yellowish flowers which are followed by crimson berries. These hang all winter.

ORIENTAL BITTERSWEET. Heavy foliage with orange flowers followed by crimson pods. Will do well in any soil or situation.

\section{HARDY SHRUBS}

SPIREA VAN HOUTTEI. (Hardy Bridal Wreath). Slender bushy shrubs, upright in growth but in May and June a fountain of arching, snowy white bloom. The rich green foliage is especially pleasing in its autumnal colorings. For specimen or foundation plantings Spirea Van Houttei is unequalled and it makes a most attractive flowering hedge.

FROEBEL'S SPIREA. A Japanese type of Spirea with bluish green leaves and red stems. Rather more dwarf than Van Houttei. Begins to bear flat clusters of rose colored flowers almost as soon as planted and continues in bloom until late autumn. Bushy plants. $1 \frac{1 / 2}{2}$ to 2 feet high.

SPIREA, ANTHONY WATERER. Very compact, growing from 15 to 18 inches tall; deep crimson flowers. Perfectly hardy; fine for low clumps.

GORNUS SIBERICA. (Red Winter Dogwood). A sturdy upright shrub growing six to ten feet high and of ored flowers in numerous fiat clusters followed by berry-like fruits of palest blue. The bark of the new shoots is a rich intense red.

HIGH BUSH GRANBERRY. Handsome dense foliage of brilliant green; produces large bunches of crimson berries, which remain on the bare branches during the winter. Height 8 to 10 feet.

SPIREA PRUNIFOLIA. Just like Spirea Van Houttei in habit of growth. flowers are very double and in clusters along the branches. Foliage turning to brilliant red in autumn.

SYRINGA or MOCK ORANGE. (Grandiflora). A large shrub of 8 to 10 feet. Very hardy, with handsome foliage. Blooms in June, producing beautiful white flow. ers in great profusion, slightly fragrant. A very vigorous grower. Good for foundation planting and also makes a fine specimen plant.

TAMARIX. Very slender stems carrying very loose, feathery sprays of light bluish-green foliage; pink flowers in late summer and autumn.

HYDRANGEA. (Arborescens.) Hill of Snow. A beautitu bluish underneath. Flat clusters of white flowers from June to August.

\section{HEDGE PLANTS}

PRIVET. Amoor (Siberian). A fine upright shrub almost evergreen with pure white flowers in June followed by purple seed pods. Also a good specimen plant.

JAPAN BARBERRY. Dense growing, thorny shrub, with drooping yellow flowers followed by bright red berries which hang all winter. This variety does not harbor wheat rust and may be planted anywhere.

Hedge Plants, 25c each; 10 for $\$ 2.00$, postpaid. By express, 100 for $\$ 18.00$.

BUSH HONEYSUGKLE. Long-lived shrub of dense upright growth, eventually reaching a height of 5 to 8 feet. In spring it bears myriads of fragrant pink blossoms followed by a profusion of vinous red "twin" berries that hang on the branches until winter. A valuable shrub for screens or massing.

FORSYTHIA or GOLDEN BELLS. The first flowering shrub to greet the opening spring, the pretty golden bells lining the branches before the leaves appear. Forsythia makes a fine arching growth; the foliage all through the summer is a datk and handsome green.

SNOWBERRY. One of the prettiest of low-growing shrubs, hardy, and succeeding in almost any soil or in partial shade. The tiny pink flowers are followed by axy white berries which last well into the winter.

PURPLE LILAG. An old-time favorite that will always remain popular. Flowers have a delicate but unique fragrance.

WHITE LILAC. Similar to the purple variety in growth. Very vigorous and hardy, 8 to 10 feet high, bearing clusters of creamy-white flowers. Is very fragrant and is fine planted with the purple variety along drives or for screening unsightly views.

SNOWBALL. The common Snowball has been a favorite for many years and is always ready with its load of white ball blooms to supply the necessary decoration for Memorial Day. No home should be without it.

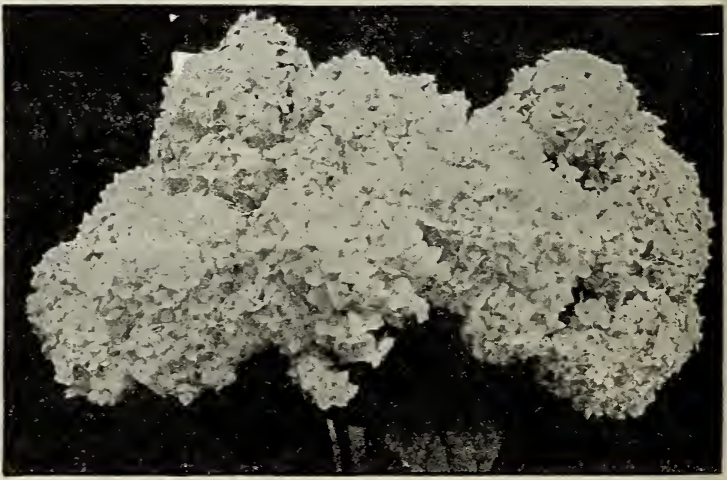

Hydrangea Paniculata.

HYDRANGEA PANICULATA. Creamy white flowers changing to pink: borne freely in immense panicles. Easily grown, beginning to bloom the first of July and continuing until fall. 


\section{OLDS' NORTHERN GROWN TREES}

Note. Everything offered on this and the following page will be sent from our growing station in eastern Wisconsin, not from Madison.

Prices, all varieties Apples, 4 to 6 foot trees, shipped by express: Each, 50c; 10 for $\$ 4.75$.

\section{SUMMER VARIETIES APPLES}

YETTOW TRANSPARENT. An early August apple of highest quality for home use but too tender to ship. Pale waxy yellow in color.

IOWIAND RASPBERRY. August. A medium sized apple of clear white, shaded with crimson. Juicy, sub-acid flesh, almost sweet. A home orchard apple.

DUCHESS OF OLDENBURG. A large and beautiful apple ripening in late August and early September. Yellow and red streaked and mingled. Very juicy and rich flavored, fairly tart. Exceptionally good for cooking and the best commercial extra early. Well known.

GOLDEN SWEET. A good early sweet sort.

RED AS T R A CHAN. Large, beau. tiful de e p crimson. Val uable $f \circ \mathrm{r}$ market

T E T O F

SKY. Me dium, yellow, striped $r$ ed, nice $f \circ r$ eating. The be s t early apple.

We guarantee good stock and $g$ o 0 d pa c k i n $g$. ercise the great est care to hare all stock genuine. we do not give a $\mathrm{n} \mathrm{y}$ warranty, and in case of any error on our part it is mutually agreed, that we shall not at any time be held responsible for greater amount than the original price of the goods.

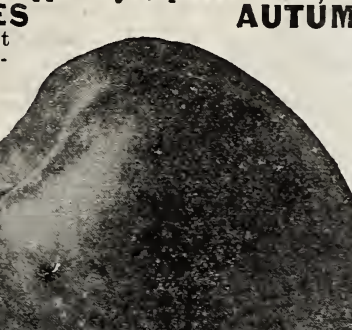
VARIETIES APPLES

WEALTHY. The one fall apple with a perfect score as regards dessert, cooking and market qualities in contests of the Wisconsin Horticultural Society. Round fruit of rich dark polished red. The aromatic tender flesh is juicy, sub-acid, and of delicious flavor. The Wealthy is an early and annual bearer. ST. LAWRENCE OR FALI STRIPE. Large, streaked red and greenish yellow; fine quality. WOLF RIVER. The largest apple grown. Greenish-yellow shaded red.

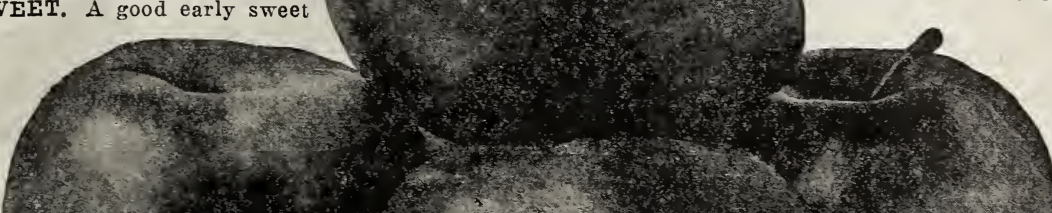
eating out of hand or cooking $b$ u $t$ a little coarse in tex A U TUMN S T $R$ A W. B E R R $\mathbf{r}$. $\mathrm{T}$ e $\mathrm{n}$ d e $r$, juicy, productive; fine for $\mathrm{h} o \mathrm{~m}$ e orchard.
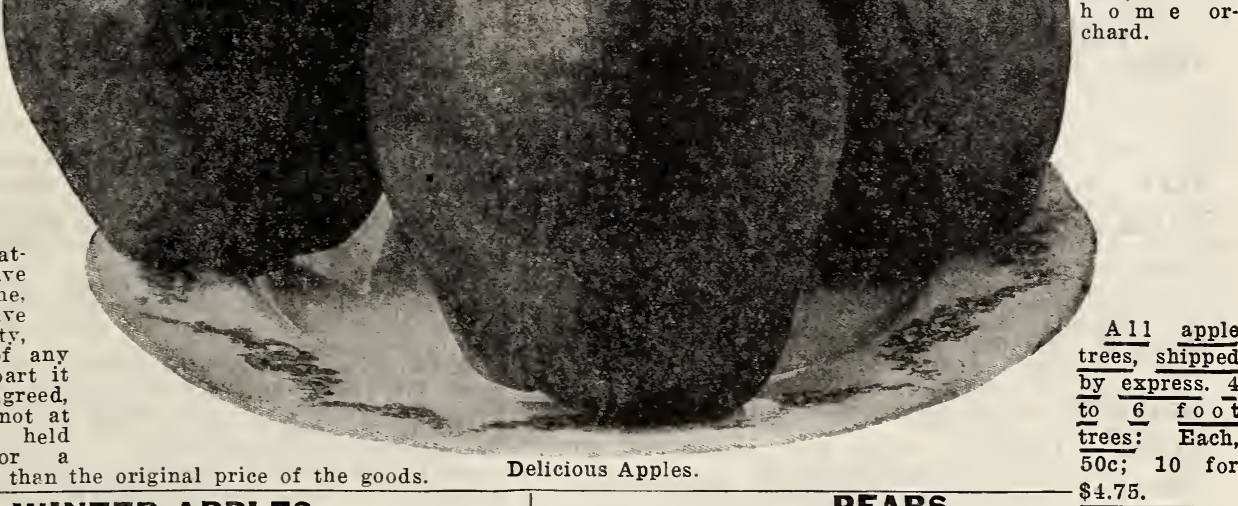

\section{WINTER APPLES}

BEN DAVIS. Large, handsome, striped, valuable.

CORTIAND. New, highly recommended from New York.

DEIICIOUS. Good size, fine quality. Tree good grower and hardy.

FAMEUSE. (Snow.) Medium, deep crimson, flesh white, of best quality.

GANO. An improved Ben Davis, nearly covered with deep, dark red.

GRIMES' GOLDEN. Good size, Jellow, of highest quality; very productive.

GOLDEN RUSSET. Medium, dull russet, quality the best. Tree enormous and early bearer. Valuable for the market.

HUBBARDSTON. Large reddish russet, crisp, juicy

JONATHAN. Medium, red, extra quality.

McINTOSH. Medium size, dark red, good quality,

juicy, sub-acid.

NORTHWESTERN GREENING. Hardy, yellow, rich, of good size: extra long keeper.

NORTHERN SPY. Large, striped, mild, sub-acid and tender, with a rich, delicious flavor.

PEWAUKEE. A hardy winter apple, good grower and keeper.

SALOME. Long keeper, annual bearer, medium and uniform size: good quality.

SEEK-NO-FURTHER. (Testfield.) Medium to large, round, striped with dull red, russet dots; fine grain, tender, rich and excellent.

STAYMAN'S WINESAP. A rery popular winter apple. Largely planted.

TALLMAN SWEET. Medium, Jellow, rich.

Good keener.

WINDSOR. Large, oblate, slightly conical, light greenish yellow covered with marbled dull red and russet; fine grained, spicy, sub-acid. Very good.

WINTER BANANA. A beautiful golden yellow, crimson cheeked apple with a decided banana flavor. Tree hardy.

Tie can also supply Yellow Bellflower, Pound Sweet, Bailey Sweet, Maiden's Blush, Perry Russet, Willow Twig and Wagner.
Delicious Apples $\$ 4.75$.

\section{PEARS}

BARTLETT. Large, buttery, juicy, high flavored, great bearer; very popular, early. (August.)

CLAPP'S FAVORITE. Very large, early, vellow and red, with russet specks; melting rich. (August.)

FLEMISH BEAUTY. One of the hardiest; large and most popular. (September.)

HOWELI. Large, yellow, with red cheek; rich, sweet, melting; early bearer, productive. (October.)

KEIFFER. Its large size, handsome appearance and remarkable keeping and shipping qualities make it ex ceedingly profitable for market. Very hardy. (Norember.)

SECKEL. Small, yellowish brown when fully ripe with deep brownish red cheek; flesh very fine grained sweet, exceedingly juicy; one of the richest flavored pears known. (September.)

SHELDON. Medium size; yellow, with a richly shaded cheek; flesh a little coarse, melting, juicy, highly perfumed flavor, of first quality. Tree vigorous, erect and handsome; hardy and productive. (October.)

Prices, all varieties Pears, 3 to 4 foot trees, by express: Each 75c; 10 for $\$ 7.00$.

\section{CRAB APPLES}

HYSLOP. Large, deep crimson; most beautiful.

TRANSCENDENT. A red and yellow Siberian.

WHITNEY. One of the largest; splashed carmine, firm, juicy, great bearer. Fine eating apple.

Prices, 4 to 6 foot trees: Each $50 \mathrm{c} ; 10$ for $\$ 4.50$.

\section{ORNA MENTAL TREES}

BECHTEL'S CRAB. A dwarf tree of great beauty cov ered with large double rose-like blossoms. A hardy and popular variety.

DOUBLE-FIOWERING PLUM. Very early-flowering and hardy. Large, double flowers of rosy pink which set close on the branches and open as the leaves unfold in early spring.

FLOWERING ALMOND. Very dwarf. The double pink flowers are borne on the bare stem before the foliage ap-

pears. A beautiful and striking ornamental.

2 to 3 foot trees, by express: Each $75 \mathrm{c} ; 3$ for $\$ 2.00$. 


\section{OLDS' PLUMS, CHERRIES, GRAPES, SHADE TREES \\ THE NEW MINNESOTA PLUMS \\ These "New Minnesota Plums" were produced by cross- \\ CHERRIES} ing the Burbank and other Japanese varieties with our hardy native sorts. They are hardy anywhere in the Northwest. They begin to bear the second year from planting and produce fruit that will equal in size and quality the best California plums.

$\star$ LORING PRIZE. This plum was awarded a $\$ 100.00$ prize by the Minnesota Horticultural Society as the best in Minnesota. Big red plums as large as good-sized peaches and much the same shape; of wonderfully fine flavor. $\star$ MONITOR (MINNESOTA NO. 70). An unusually strong tree, its strong shoulders enabling it to carry its immense load of dark red fruit without breaking. It is an annual bearer, yielding a large crop each year.

$\star$ UNDERWOOD (MINNESOTA NO. 91). This is the earliest and hardiest of the large new plums, ripening August first to August 15 th, and attaining a size of $13 / 4$ inches in diameter. The tree is one of the strongest. Fruit red, juicy; very small pit, free stone

$\star$ RED WING (MINNESOTA NO. 12). A regular bearer and hardy as far north as Minneapolis. Fruit very large, firm and of excellent quality. Color, yellow overlaid with bright red. Stone small and free, very sweet. Season, third week in August.

$\star$ TONKA (MINNESOTA NO. 21). Hardy up to a hun dred miles north of Minneapolis. One of the most productive of all these plums. Fruit uniform in size, averaging one and three quarters inches in diameter. Season, August

\section{5th. Yellow, sweet, free stone.}

OPATA. The finest plum for home gardens or where there is room for but one or two fruit trees. A dwar grower, bearing heavily one year after it is planted. The fruits are purole with firm yet juicy green flesh of excellent quality. Tender skin and very small pit. Free

SAPA. Dark flesh of fine quality. Five-foot trees at ree rears bear 1 to $11 / 2$ bushels each and keep it up.

WANETA. The most delicious of all plums and Prof. Hansen's masterpiece. It is a cross between a large American variety and the Japanese Apple Plum, a sort originated by Luther Burbank. The Waneta combines im. mense size with attractive appearance and rich sweet flavor. Absolutely hardy.

HANSKA. Beautiful in appearance, highly colored, rich in flavor. A great acquisition

\section{OTHER PLUMS} ELIIOT. Productive, large, firm, bright red, good uality, small pit. Very good late plum.

WINONA. High quality, firm, juicy, semi-clingstone; Wular bearer: choice for home use.

ST. ANTHONY. Another good Sand Cherry Hybrid similar to Sapa but more vigorous, very productive. Fruit of good size, purple flesh; excellent for jelly or canning. ZUMBRA CHERRY PLUM. As a hardy substitute for the black sweet cherry, this will please you. Medium size with small free pit. One of the best for canning when fully ripe; very productive when pollenized by some of the other hybrids like St. Anthony, Compass or Opata.

NICOIET CHERRY PLUM. Nearest to the true sour cherry and for pies or sauce hard to distinguish from it. Pit small and free; juicy; dull red color. Ripens middle of August. Rather dwarf grower. This new hybrid is very prolific and will prove satisfactory for a culinary

GERMAN PRUNE. Large, dark purple; good, hardy nd productive.

LOMBARD. Medium, violet red, juicy; good, hardy and productive; the leading market variety.

REINE CLAUDE. (Bavey's Green Gage). Very large,

greenish, fine flaror.

Trees go by express at customers' expense.

Prices, all Plums, 3 to $4 \mathrm{ft}$. trees, by express; each, $75 \mathrm{c}$; 10 for $\$ 7.00$.

3 to $4 \mathrm{ft}$. trees can be sent by parcel post if you will add $20 \mathrm{c}$ per tree.

\section{RUSSIAN APRIGOTS}

Recommended where peaches cannot be grown. They re early bearers and productive.

SUPERB. A hardy seedling from Kansas. The best flavored, most productive, hardy apricot yet produced. Golden yellow. Each, 75c; 10 for $\$ 7.00$, by express.

\section{ASPARAGUS PLANTS}

We want to call attention to our Asparagus Plants.

No better plants can be grown than those grown on our peat soil and no better results can be obtained than by planting One-Year Old Plants. We recommend them because they are more easily handled and can be properly planted with less work than the long rooted Two-Yearold Plants. They are also cheaper and after the first year they will produce more than Two-Year-Olds. See page 29 $\leftarrow$ EARLY RICHMOND. An early variety of extrem hardiness bearing large crops. Light to dark red, juicy. †MONTMORENCY. Large, bright crimson, very juicy; strong, upright grower; one of the best late varieties.

ENGLISH MORELLO. Large, dark red, juicy; tree omewhat dwarf in growth.

Prices all Cherries, 3 to 4 foot trees: Each, 60c; 10 for $\$ 5.50$, by express.

\section{GRAPES}

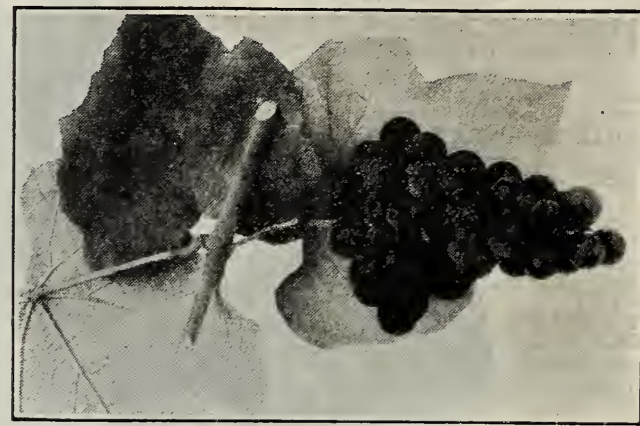

Concord Grapes.

CONCORD. The old standard purple grape, doing well everywhere. A heavy yielder.

WORDEN. An improved Concord; sweeter, larger in bunch "and berry, and a week to ten days earlier. Black with purple bloom

DIAMOND. A leading early white grape.

BRIGHTON. A bright red grape of large size, exceedingly juicy. Sweet sprightly flavor.

DELAWARE. An exquisite dessert grape. Light red with very thin skin, juicy, sweet, spicy, and aromatic. Rather small berries but of rare flavor. The standard of quality for grapes.

BETA. The grape for the extreme north, a hybrid be tween the wild grape and the Concord. Medium-sized, jet black, in good bunches, juicy and of fair quality.

MOORE'S EARLY. Bunch and fruit large, very productive and of superior quality. Vine exceedingly hardy. Desirable for an early market. Its hardiness particularly adapts it to Canada and Northern portions of the United

NIAGARA. Occupies the same position among white varieties as Concord among the black; the leading profitable market sort. Bunch and fruit large, greenish white chanting to pale yellow when fully ripe. Skin thin but tough; quality much like Concord.

POCKLINGTON. Vine and fruit large; when fully ripe a light golden yellow; juicy, tender, sweet and with little pulp. Vine thoroughly hardy, strong grower, free from mildew; productive. One of the most satisfactory white varieties.

CAMPBELL'S EARLY. The fruit is large, often an inch or more in diameter, glossy black with a purple bloom, sweet and juicy, with few seeds. They ripen from the fifteenth to the last of August. As a keeper and ship. per this variety is unequalled by any other American grape while as a dessert grape it is delicious.

Any of the above grapes, postpaid, each, 30c; 10 for $\$ 2.50$; by express, 100 for $\$ 22.00$.

\section{SHADE TREES}

For lawn or street planting. Strong, well-rooted, 6 to 8 foot trees. Prices except as otherwise noted, by express: Each, $\$ 1.00 ; 3$ for $\$ 2.75$.

MOUNTAIN ASH. Fine foliage with red berries.

SILVER MAPLE. A large and rapid growing shade

RUSSIAN MULBERRY. Bears fruit like the black-

WHITE ASH. Resists drought well. A rapid grower. HARDY CATALPA. Rapid grower, with fragrant flowers.

CAROLINA POPLAR. An improved Cottonwood.

WHITE ELM. The best shade tree.

BOX ELDER. A rapid grower.

PURPLE LEAF MAPLE. 5 to $6 \mathrm{ft}$., $\$ 1.50 \mathrm{each}$, by express.

HORSE CHESTNUT. 4 to $5 \mathrm{ft}$., $\$ 1.50$ each, by express. WHITE BIRCH. 4 to $5 \mathrm{ft}$., $\$ 1.00$ each, by express.

WEEPING BIRCH. 4 to $5 \mathrm{ft}$., $\$ 2.00$ each, by express.

BUTTERNUT, 4 to $5 \mathrm{ft}$., $\$ 1.00$ each, by express. 


\section{STRAWBERRIES}

Our Strawberry Plants are never sent with other goods. They are freshly dug, well packed and sent by themselves at planting time. They are all Northern grown, large plants, well rooted.

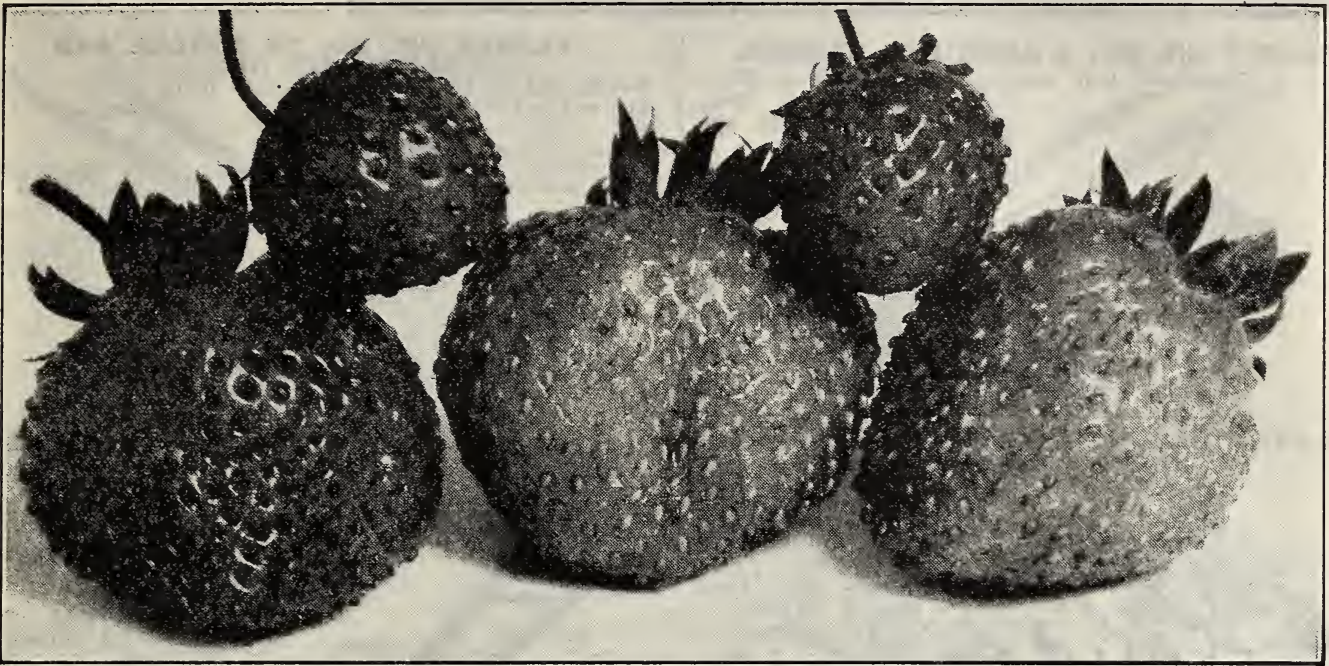

Three Average Mastodons, With Two Just Normal Size Champions, a Standard Variety, on Top.

\section{THE MASTODON EVERBEARING}

The great Strawberry novelty. It is a sure money maker and you should start a patch of the Mastodon now so you can enjoy the fruit this summer and have plants to sell your neighbors next spring.

The heaviest producing strawberry. Some have measured five inches in circumference. Nine selected berries have filled a quart box. It is easy to select eighteen that will fill a quart box. The plants are always big and vigorous and well supported by a heavy root system. Like all everbearing varieties, the Mastodon will nearly always take a rest during about six weeks of the hottest, driest part of the summer; after that it bears until freezing weather begins. It does not bear smaller fruit later in the season; in fact the fall crop is usually larger than that produced in the spring. A four acre tract produced 22,176 quarts in 28 weeks or nearly 5,600 quarts per acre. Figure what this will mean in dollars and cents at the price of berries in your locality and take into consideration that fall berries usually sell for much more than those produced in the spring.

Berries are firm and solid, of the finest flavor, although on account of their unusually large size we do not recoinmend them for shipping a great distance. The Mastodon is not an experimert; it is absolutely the best flavored, largest heaviest producing and finest berry ever introduced and we guarantee it unqualifiedly. Prices postpaid: 12 plants for $90 \mathrm{c} ; 25$ for $\$ 1.50 ; 100$ for $\$ 3.50 ; 1,000$ for $\$ 20.00$.

\section{STANDARD VARIETIES}

\section{SENATOR DUNLAP (Perfect} Flowering.) We believe this is the most satisfactory all-around strawberry now on the market. The plants are medium in size, long rooted and therefore drought-resisting. It is unusually productive, beginning to ripen early and continuing to bear a long time.

The fruit is of medium size, smooth, regular and firm and of a beautiful red color extending well to the center of the berry.

DR. BURRELL. (Perfect) : Medium. "The Million Dollar Berry." A cross between Senator Dunlap and Crescent. Does well in all soils and climates. Fruit large, dark red, glossy and fine. Add some $\mathrm{Dr}$. Burrells to your order for variety.

WARFIEI. (Imperfect Flowering.) It is small but a vigorous gi ower, with foliage tall enough to pr otect the blossoms from the late frosts.

It is one of the best of shippers and its rich color, good size, fine shape and flavor make it an almost perfect market berry. It is midseason, dark red, and firm.

AROMA. (Perfect Flowering.) Plants large, vigorous, with a splendid root system; always make about the right amount of plants for a good fruiting row. Fruit large, holding its size well throughout all the pickings.

The berry is nearly round, smooth and perfect in form of a beautiful bright, glossy red color, very firm and of high quality. It is medium late in season, much more than average in yield and a sure cropper every year.

Prices for any of the above four varieties: Postpaid, 25 for $45 \mathrm{c} ; 100$ for $\$ 1.50$. - By express: 1,000 for $\$ 7.00$; 500 at 1,000 rate. Cultural leaflet on request.

A Box of Progressive Everbearing Strawberries.

\section{EVERBEARING STRAWBERPIES}

Everbearing strawberries are no longer an experiment. Planted early in the spring, they will ripen in August, yielding the finest of fruit until November's freezing-up time comes. Then in June they will yield again and after a few weeks' It-st will throw up new blossom stalks and yield still again through the following fall.

PROGRESSIVE. The best everbearer except the New Mastodon. A strong hardy plant, producing many runners. Foliage large and healthy, fruit of good size. Prices, postpaid: 25 for $\$ 1.00 ; 100$ for $\$ 2.65$. By express: 1,000 for $\$ 18.00$; 500 at the 1,000 rate. 


\section{Planet Jr. Garden Tools}

The New "Planet Jr." Catalogue is the hand. somest, best and most instructive book ever issued profit. Full of true and handsome llustrations. mati it free to any address on application.

PLANET JR. NO. 4 GOMBINED SEEDER.

No. 4 Combined Hill and Drill Seeder, Wheel Hoe,

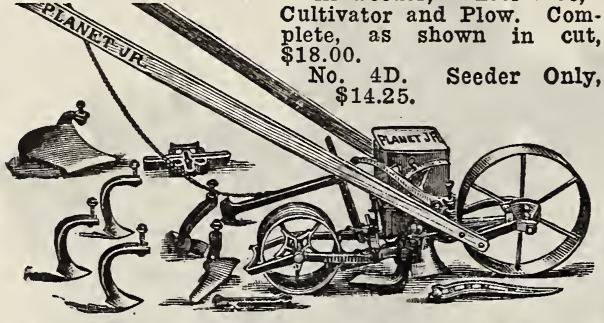

PLANET JR. NO. 25 COMBINED SEEDER.

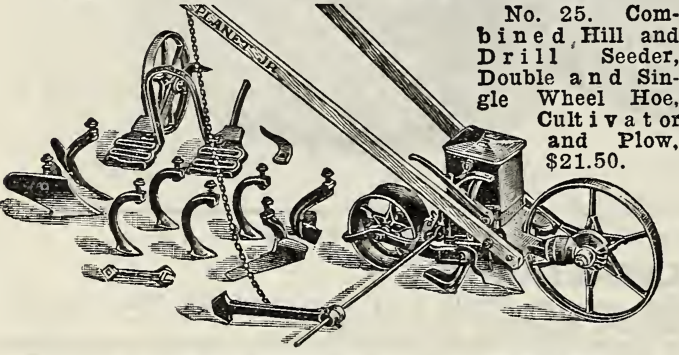

PLANET JR. NO, 26 DRILL SEEDER.

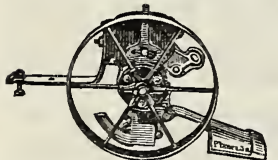

A new style, large size seeder $\$ 20.00$.

PLANET JR. NO. 35 SEEDER ATTÁCHMENT.

Fastens to any Wheel Hoe or

\section{"43" FOR THE TREE. Why Let a Tree Die?}

When in a few moments you can repair the tree that has been damaged; make possible the healing of a wound; keep out dis. ease.

" 43 " For the Tree contains those acids that destroy fungi and insects. The medicinal oils are penetrating and find their way into every part of the wound. A quick, easy application forms an elastic, waterproof coat, keeping out water, air, infestation and decay and permits the wound to heal.

Order Plastic " 43 ", for carities; order Iiquid " 43 " to brush over pruned trees, at sawed off limbs, broken branches, surface wounds and to coat around bottoms of trees to prevent rabbits, small animals and insects from attacking the tree.

“43" WILL SAVE YOUR TREES.

Recommended by Horticulturists and Tree Surgeons.

Prices, either Plastic " 43 " or Liquid " 43 ": Ib. can $65 \mathrm{c}$; by mail, $75 \mathrm{c}$. $21 / 2-1 \mathrm{~b}$. can, $\$ 1.55$; by mail, $\$ 1.75$. 5 -lb. can, $\$ 2.95$; by mail, $\$ 3.25$. 10-1b. can, $\$ 5.75$; by mail, $\$ 6.10$

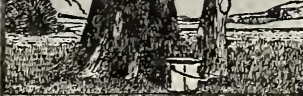

\section{PLANET JR. NO. 12 DOUBLE AND} SINGLE WHEEL HOE

Recognized as the best combination dou

ble and single wheel hoe now in

use. The assortment of attach.

ments enables one to do plow-

ing, running furrows, and gen-

eral cultivating work.

Equipment: As shown

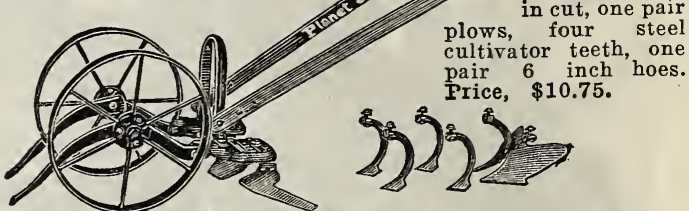

$\rightarrow 00$

PLANET JR. NO. 17 SINGLE WHEEL HOE.

Equipment: One large garden plow; three steel cultivator teeth; one pair of six inch hoes. Price, $\$ 7.75$.

PLANET JR. NO. $171 / 2$ SINGLE WHEEL HOE.

Same as No. 17 without the garden plow. Frice, $\$ 6.75$.

\section{PLANET JR.NOW 119}

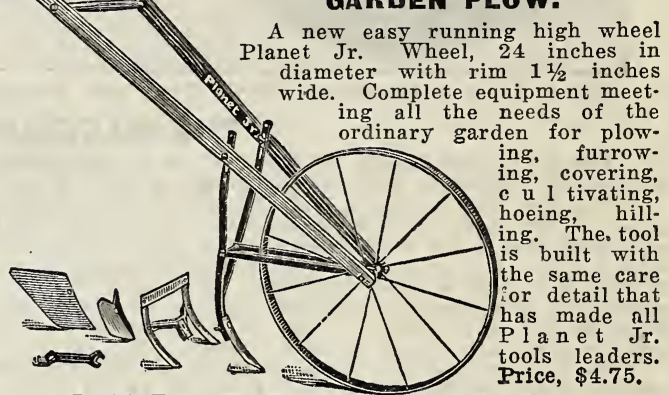

PLANET JR. STAR PULVERIZER.

A new disc style of tool with oscillating blade. Price, $\$ 3.25$.

PLANET JR. NO. 2 GRASS EDGER.

For edging the grass bordering on walks. Price, $\$ 1.60$. PLANET JR. FERTILIZER DISTRIBUTOR. Will distribute from 100 to 2,000 pounds of commercial fertilizer per acre as desired. Spreads from 4 to 30 inches on the ground and can be used for all width rows.

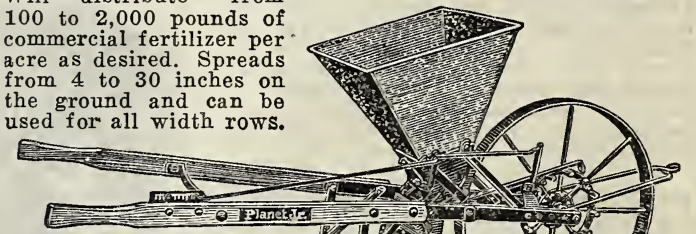

Hopper holds one bush. el. Price, $\$ 27.00$.
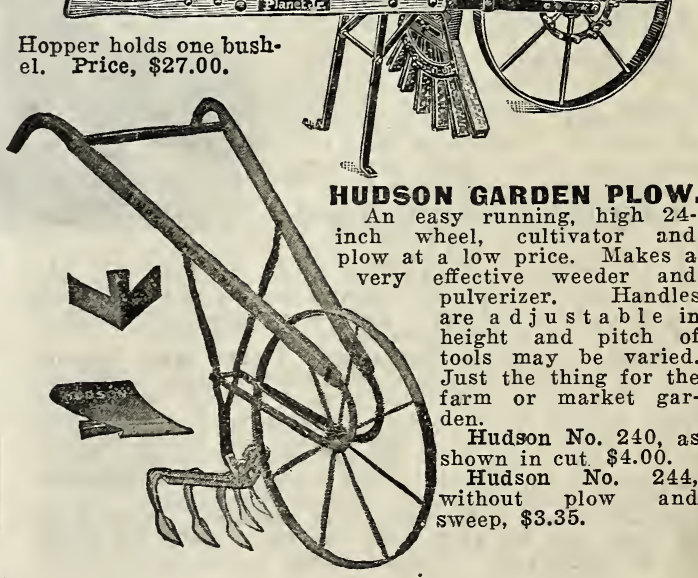

HUDON GARDEN PLOW.

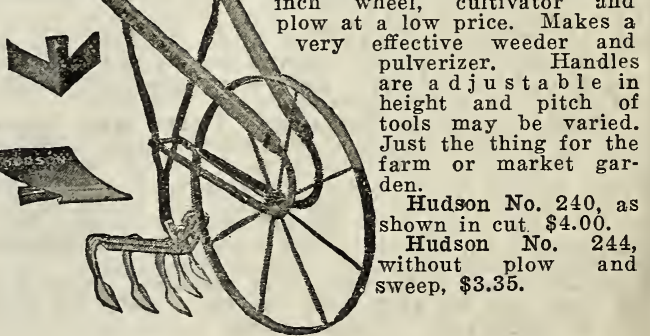




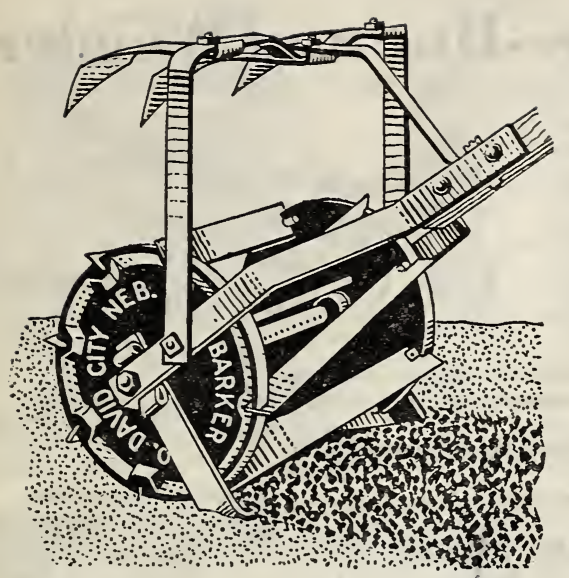

BARKER

WEEDER, MULCHER AND CULTIVATOR - 3 TOOLS IN ONE

Makes Gardening Easy and Insures Best Yields.

The Barker cuts the weeds under the ground, cultivates the soil and makes the essential dust blanket or mulch-all in one operation. Works like a lawn mower.

In market gardening labor is the chief item of expense. It is no idle boast that "a boy with a Barker can do more and better work than ten men with hoes," or than two men with wheel hoes. Many leading commercial market gardeners have discarded all other kinds of tools since trying the Barker.

No. 6D, 6-Inch Cut, for lettuce and close row crops, \$9.25.

No. $8 \frac{1}{2}$ D, $81 / 2$-Inch Cut, for onions and similar crops, $\$ 10.60$.

No. 10D, 10-Inch Cut, best size for most crops, $\$ 11.75$.

No. 11D, 11-Inch Cut, for beets and rutabagas, $\$ 12.60$.

No. 12D, 12-Inch Cut, cleans up the weeds a little faster than the other sizes, $\$ 13.45$. Recommended for big gardeners.

Prices include all attachments. Money back if not satisfied. Goods guaranteed five years. Not mailable.

Note- "Gardening for Profit and Pleasure," a beautiful illustrated 24 page book on weeding, mulching and cultivating, mailed free on request.

\section{HUDSON \\ GULTIVATOR HOE.}

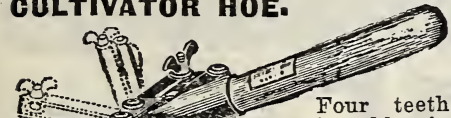

aos 1 adjustable in

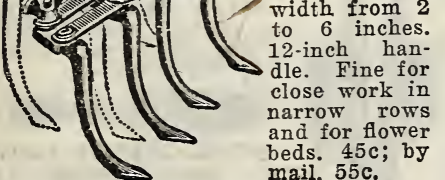

LONG HANDLED HUDSON

Same as the preceding but with 4 . foot handle instead of 12 -inch. A very satisfactory tool. Specially desirable for children. Price, 55c; by mail, 65c.

DUBL-DUTI CULTIVATOR. 5 inch blade. Double edged rocker blade at bottom, rake at top. Long handle, \$1.15; by mail, $\$ 1.30$.

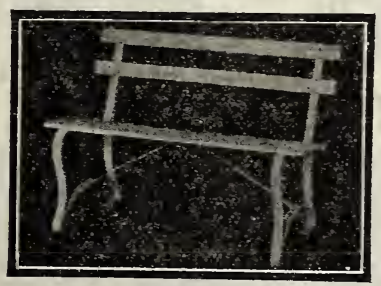

\section{AUTOCRAT LAWN SETTEE.}

Strong, durable, attractive. Just the thing for the private lawn or public park. Thousands are in use all over the country.

4 feet long, as shown in cut, $\$ 5.00$.

5 feet long, with seat support, $\$ 5.50$.

6 feet long, with seat support, $\$ 5.75$.

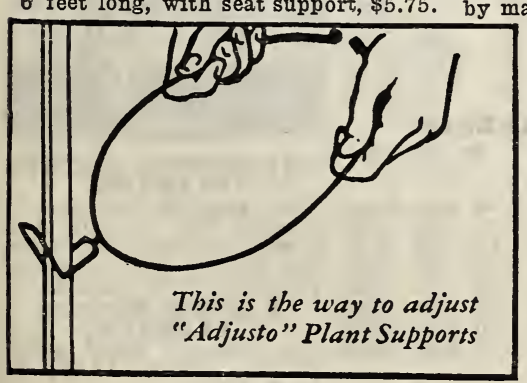
$\$ 2.25$.

GYCLONE SEEDER.

The Cyclone has a national reputation as a High. Grade Seed Sower. It is built, not for cheapness, but for durability and accurate work. Scatters seed evenly both sides and may be quickly adjusted for different seeds. No waste of seed. Just the thing for sowing all kinds of clover and grass seed, millet, rape, and even grain. Price, reduced, $\$ 2.00$; by mail,

HORN SEEDER. Extremely simple but substantially made. Does very satisfactory work if properly used. Made by the Cyclone people. Price, $\$ 1.00$; by mail, $\$ 1.10$.

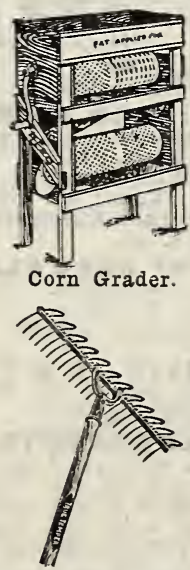

IAWN RAKE. 24-Tooth, 85c;

\section{HERO GORN GRADER.}

A Corn Grader that is a real grader. You should plant kernels that are all alike in size and shape if you want a perfect uniform stand. The Hero grades that way.

Leading farmers and corn growers ev. erywhere testify to the perfect work done by this grader. It will pay for itself in one season. Price, $\$ 18.00$.

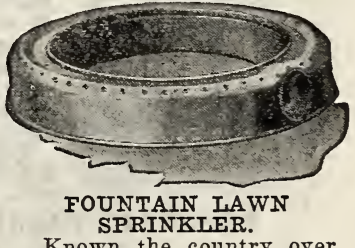

Known the country over for its fine mist-like spray. Superior to any other sprinkler on the market. Made of brass. Price, 90c; by mail, $\$ 1.00$

\section{HALF-FOUNTAIN} SPRINKLER.

Price, 80c; by mail, 90c.

\section{THE RAIN KING.}

For circular spraying. Durable and sub. stantial. Price, $\$ 3.50 ;$ by mail, $\$ 3.75$

\section{ADJUSTO PLANT SUPPORT.} For Tomatoes, Dahlias, etc.

An adjustable, practical and durable plant support. Consists of two parts: an oak stake pointed at the bottom and painted green and a hoop of toughest galvanized steel, also painted green. Adjustable to any height. With 3 ft. stake, $30 \mathrm{c}$ each; doz......\$3.00 With 4 ft. stake, 35c each; doz...... 3.60 With 5 ft. stake, $40 \mathrm{c}$ each; doz...... 4.20 For Potted Plants, etc.

With 18 in. stake, 12c each; doz.....\$1.20

With 2 ft. stake, $15 \mathrm{c}$ each; doz

(Plant supports not mailable)
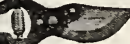

CAIIFORNIA

PRUNING SHEAR A thoroughly reliable pruning shear. Length, 9 inches. Price: 90c. by mail, $\$ 1.00$.

का

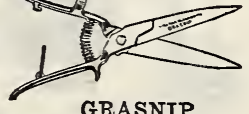

GRASNIP

SHEARS.

For grass, vines, lig h t shrubbery etc. Length, 12 inches. An allaround practical tool. Price: \$1.05. by mail, $\$ 1.15$.
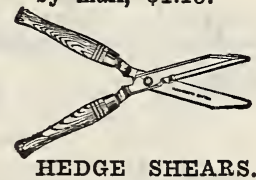

Well made, strons and durable. 6-inch blade, $\$ 1.75$; by mail, $\$ 1.85 ; 8$ inch blade, \$2.50; by mail, \$2.65; 10 . inch blade, $\$ 2.85$;

by mail, $\$ 3.00$.

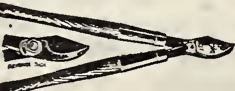

IONG HANDLE PRUNING

SHEARS.

Special heavy 26 inches long. $\$ 3.25$; by mail, $\$ 3.40$.

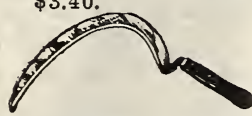

GRASS HOOK.

Forged stee l, $60 \mathrm{c}$; by mail, $65 \mathrm{c}$. GRASWIP.

Cut your grass and weeds without stooping. Swings like a golf stick. Price, $\$ 1.00$; by mail, $\$ 1.10$. 


\section{(0)"Norcross" Cultivator-.Hoe and Weeder}

1. Will cultivate closer to plants without injuring $t$ hem than ang other type of implement known, leaving the soil level, loose and untrampled. The sharp, tapering shovels enter the ground easily and are so arranged, one with another, as to literally tear up every inch of the soil from one to five inches deep, as required.

Detachable steel prongs, malleable head, extra high grade handles. Finely finished throughout.

Three sizes, suited to both men and women, and the average cost is only that of a common hoe.

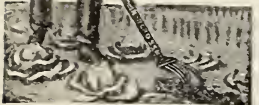

SEICHARD'S COMBINATION SPRINO-TOOTH Mrgic WVeder Hoen

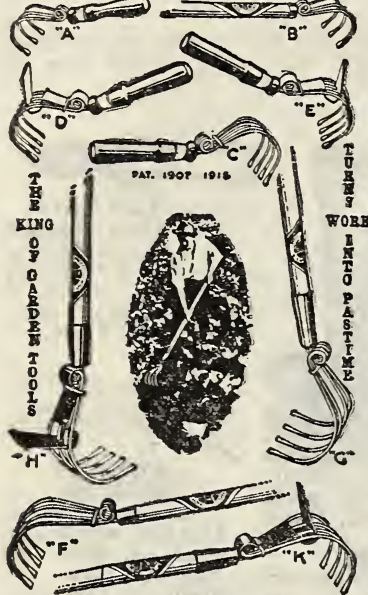

MAGIC WEEDER HOES.

Style A. 3 tines, 9 inches long. A very popular and useful little tool. $20 \mathrm{c}$; by mail, $25 \mathrm{c}$.

Style B. Same as Style A except with longer handle. Length, 22 inches. $25 \mathrm{c}$; by mail, $30 \mathrm{c}$

style c. Larger and stronger than Style A. 4 tines. Width adjustable. $35 \mathrm{c}$; by mail, $40 \mathrm{c}$.

Style D. Still larger. 11 inches long, with $11 / 2$ inch blade. 50c; by mail, 60c. Style E. Same as D except that blade is " $\mathrm{V}$ ",
pointed. $50 \mathrm{c}$; by mail, $60 \mathrm{c}$. Style F. Long handle, 12 inches. Heavier than the preceding. $70 \mathrm{c}$; by mail, Style G. Larger and stronger than Style F. 48 inch handle. $\$ 1.00$; by mail, $\$ 1.10$

Style H. Four foot han. dle, with cutting blade added. \$1.25; by mail, $\$ 1.40$. Style K. Same as Style shaped. $\$ 1.25$; by mail, $\$ 1.40$.

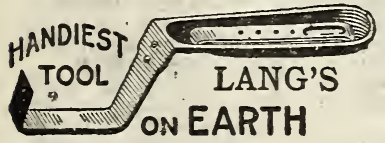

LANG WEEDER.

Price, 20c; by mail, 25c.

STEEI BOW

GARDEN RAKE.

Finest rake
made. True

temper. 14 .

tooth, \$1.35;

by mail, $\$ 1.50$.

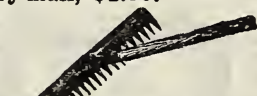

mail $\$ 1.30$

ail, $\$ 1.00$

mail, $50 \mathrm{c}$.

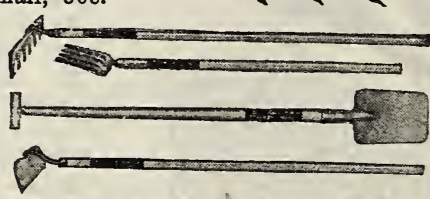

4-PIECE GARDEN SET.

Steel $5 \frac{1}{1 / 4}$ inch Hoe, with 30 inch han

dle. Steel $51 / 4$ inch Hoe, with 30 inch han-

die. Steel $51 / 4 \times 37 / 8$ inch Shorel, 26 inch hande. 7 tooth 30 inch handle. tooth Fork, 18 inch handle.

A I I - PURPOSF

RAKE. Unequalled for

removing dandelions. Is

also a first class rake

or general work.

Price, 16 inch rake, 95c; 20 inch, $\$ 1.10$. By mail, 15c more.

\section{"QUT-U-KUM"}

WeE PULL

A slight push and p u 1 l removes not only the weed but the entire root. Ridding a lions is just fun. Long handle, no

Price, 75c; by mail, 85c.
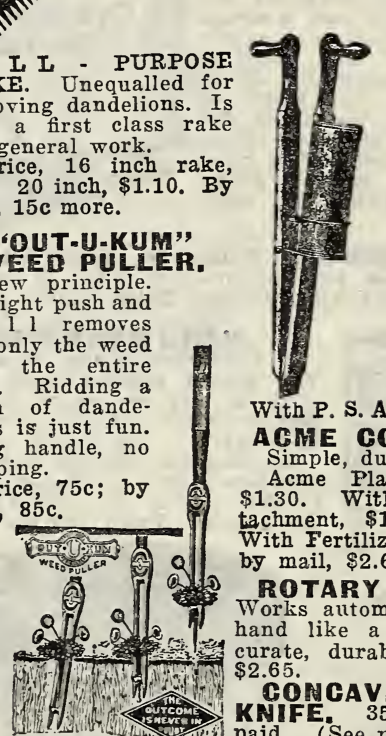

With P. S. A.

ACME GORN PLANTERS.

Acme Plain, \$1.15; by mail, \$1.30. With Pumpkin Seed Attachment, $\$ 1.30$; by mail, $\$ 1.45$. With Fertilizer Attachment, $\$ 2.50$; by mail, $\$ 2.65$.

ROTARY CORN PLANTER. Works automatically. Use in one hand like a walking stick. Accurate, durable. $\$ 2.50$; by mail, $\$ 2.65$

Goncave P O T A T O KNIFE, 35c; 3 for 90c, postNEPONSET PAPER FLOWER POTS.

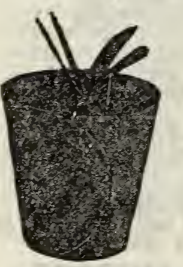

Made of strong waterproof paper; light, unbreakable and will not rot. They weigh just one-tenth as much as clay pots, are easier to handle and much less erpensive.

By mail. By exp. or freight
$21 / 4$-inch
$\begin{array}{llllll}21 / 2-\text { inch } & .25 & .75 & .20 & .65 & 5.25\end{array}$

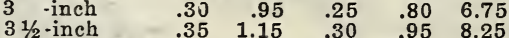

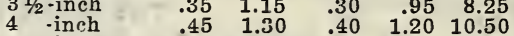

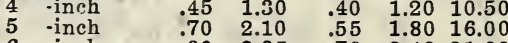

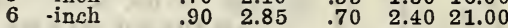

PAINTED POT AND GARDEN LABELS.

\section{By Mail. By Express} $\begin{array}{lllll}25 & 100 & 25 & 100 & 1000\end{array}$

$\begin{array}{lllllllll}\text { Painted Labels } & 4 \times & 5 / 8 & \text { inches } & \$ .10 & \$ .35 & \$ .08 & \$ .25 & \$ 2.00\end{array}$ Painted Labels $5 \times \quad 5 / 8$ inches $.13 \quad .40 \quad .10 \quad .30 \quad 2.50$

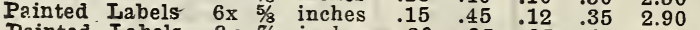

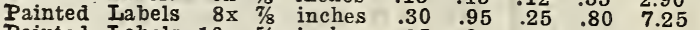
$\begin{array}{lllllllll}\text { Painted Labels } & 10 \times & 5 / 8 & \text { inches } & .25 & .85 & .20 & .75 & 6.50 \\ \text { Painted Labels } & 10 \mathrm{x} & 7 / 8 & \text { inches } & .40 & 1.20 & .35 & 1.00 & 9.00\end{array}$

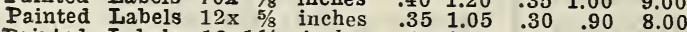
$\begin{array}{lllllll}\text { Painted Labels } 12 \times 1 \frac{1}{8} & \text { inches } & .50 & 1.55 & .40 & 1.30 & 12.00\end{array}$
G A R D E N Shank, $\$ 1.05 ; \frac{1}{\text { by }}$ mail, $\$ 1.20$.

GARDEN HOE. $\$ 1.20$; by mail, $\$ 1.35$. A

SUGAR BEET OR NURSERY MAN'S b1.25; by mail, $\$ 1.40$. 


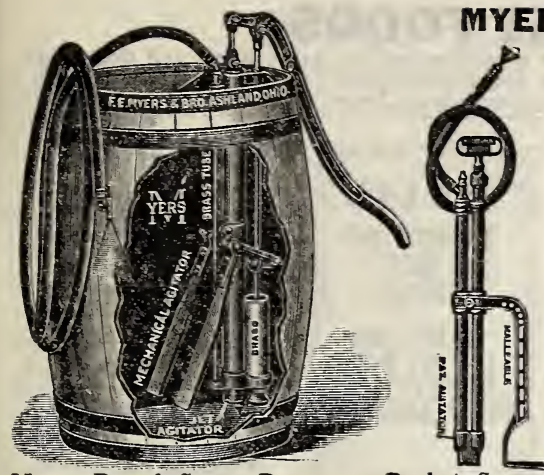

Myers Barrel Spray Pump.

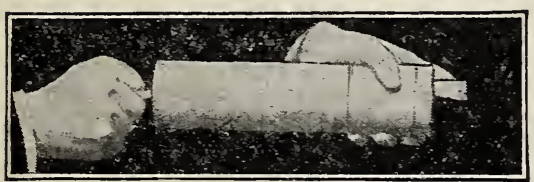

Feeney Dust Gun.

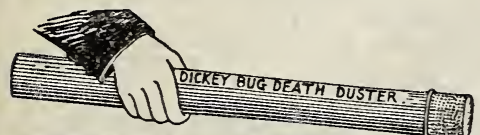

BUG DEATH DUSTER. Price, 50c. By mail, 60c.
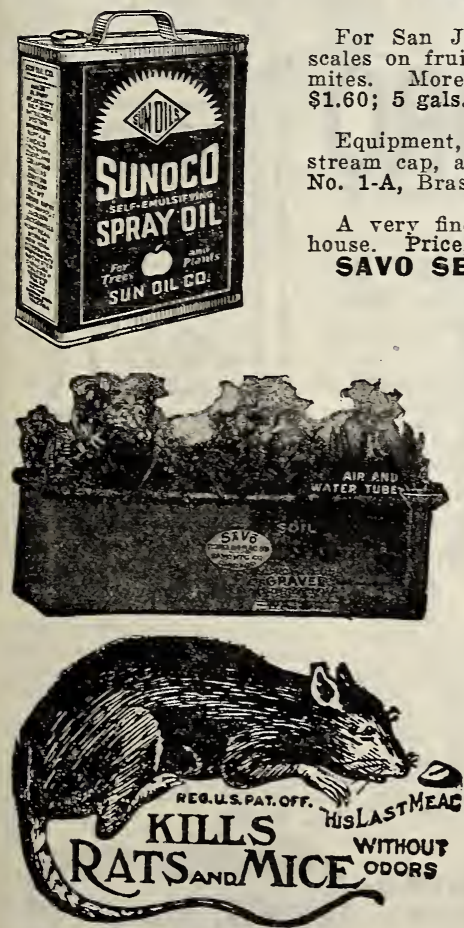

RAT CORN kills rats and mice. Harmless to live stock. Prices: $25 \mathrm{c}$ $50 \mathrm{c}$ and $\$ 1.00$ per can. By mail, $30 \mathrm{c}$ $55 \mathrm{c}$ and $\$ 1.05$.

RAT BIS-KIT PASTE.

"Just press the tube." Death to rats. Large tube, $25 \mathrm{c}$. (Not mailable.)
Bucket Spray.

S BARREL SPRAY PUMP.

The Myers Improved Brass Barrel

Spray Pump No. 305, with Bronze Ball Valves, Brass Cylinder and Discharge Pipe, is, we believe, the best and most reliable the market.

Price, complete with 15 feet of hose. Bordeaux nozzle and Mechanical Agitator, but not including barrel, $\$ 15.00$.

LITTLE GIANT BUCKET SPRAY PUMP.

Made of brass with ball valres.

Price, Complete with hose and Combi. nation Bordeaux nozzle, $\$ 5.00$; by mail, $\$ 5.25$.

HUDSON PERFECTION SPRAYER. For general high pressure purposes the Hudson Perfection is the very best. Easily operated and rery satisfactory for spraying, disinfecting or whitewashing. Capacity, 4 gallons. Price, galvanized, $\$ 7.00$; brass, $\$ 10.00$.

JUNIOR HUDSON SPRAYER.

Similar to the Hudson Perfection but smaller. Capacity, 21/2 gallons. Price, galvanized, $\$ 5.40 ;$ brass, $\$ 8.00$.

FEENEY DUST GUN.

For applying Bug Death, Slug Shot and all other dry powder. Cheaper than spraying and effective under the leares.

Price, $\$ 1.15$; by mail, $\$ 1.25$

SULPHO TOBAGGO SOAP.

Spraying plants, shrubs, trees, rines. $10 \mathrm{c}$; by mail, 15c; 8-0z. cake, 20c; by mail, $25 \mathrm{c}$.

\section{LENOX SPRAYER.}

Spraying inder the leares kills insects, removes dust and keeps the plants healthy Suds made from tobacco soap make one of the best sprays. The Lenox is most serv. iceable for hcuse and garden.

Price (including a cake of tobacco soap) 75 cents, postpaid. Extra Bulbs, 35c each.

\section{SUNOCO SPRAY OIL.}

For San Jose scale, Elm and Maple scale and all other scales on fruit and shade trees. Also effective for aphis and mites. Hore efficient than lime sulphur. Prices: 1 gal., AUTO-SPRAY NO. 1.

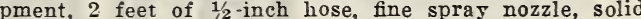
stop cock

MOTH LIQUID SPRAYER.

A very finelr finished, ornamental sprayer for use in the ( BOXES.

For Windows, Porches and Inside Use.

Made of the best galvanized steel, enameled finish inside and out. Beautiful and dura. ble. The water reservoir in the bottom of the box filled from a tube in one corner keeps plants healthy and fresh by absorbing from below the exact amount of water needed. Model A, $8 \times 91 / 2 \times 23$ inches........\$3.00 Model B, $8 \times 91 / 2 \times 29$ inches......... 4.00 Model C, $8 \times 91 / 2 \times 35$ inches.......... 4.50 Model D, $8 \times 91 / 2 \times 41$ inches.

4.50
5.00

Model B Fernery, 301/2 X91/2 ×29 inches 10.00

ARMSTRONG STANDARD SPRAY PUMP.

Ideal for spraring insecticides, for whitewashing poultry houses and cattle barns, for spraying disinfectants in buildings or on animals and poultry, for fire protection, for veterinary use, for washing windows, for washing autos.

By different arrangements of the several nozzles regularly supplied, sprays of vary. ing fineness-from a mist to a straight stream that carries sixty feet-are produced.

Price, with $3 \frac{1}{2}$-foot Hose and Nozzles, $\$ 5.00$. By mail, \$E.25.

Knapsack, for Potato Spraying, \$3.50.

Potato Extension Attach. ment, $85 \mathrm{c}$.

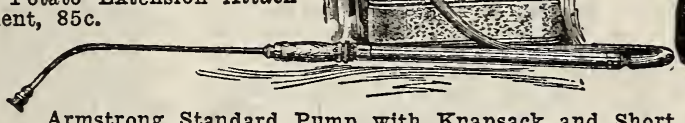

Armstrong Standard Pump with Knapsack and Short B U G DEATH Extension Attachments.
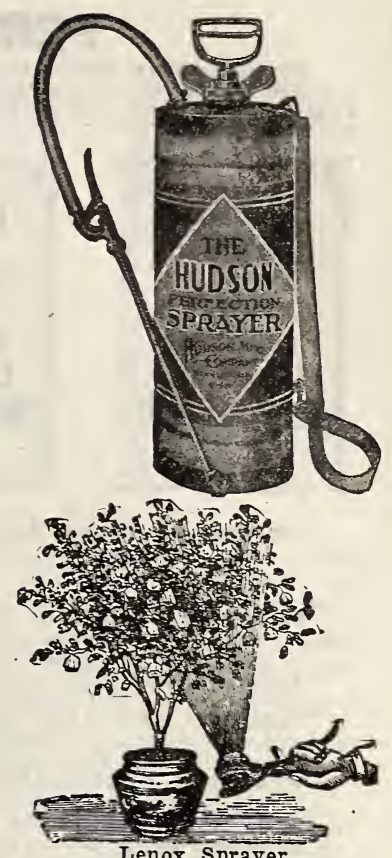

Lenox Sprayer.

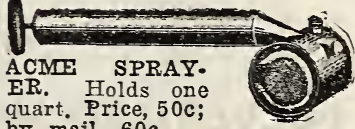

quart. Price, $50 \mathrm{c}$

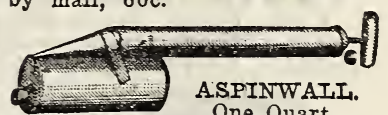

Price, 50c; by mail, $60 \mathrm{c}$.

Price, 65c. (Not mailable.)

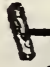

CONTINUOUS

SPRAYER.

Gires a continuou

out stroke. Price,

$80 \mathrm{c}$; by mail, $90 \mathrm{c}$.

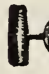

BABY MIDGET. For

the house and small

$35 \mathrm{c}$; by mail, $45 \mathrm{c}$.

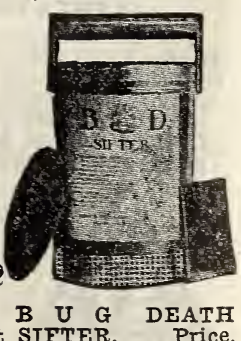

$75 \mathrm{c}$; by mail, $85 \mathrm{c}$.

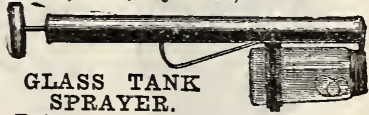

garden. Price, $1 / 2$ pt., 
Our Commercial Fertilizers are the celebrated "Red Steer Fertilizers," manufactured for us by Swift and Company.

You can greatly increase the yield and the quality of your crops by using fertilizers. Reduce your crop cost. Your seed and labor cost is about the same whether you harvest a small crop or a large crop. Fertilizers pay.
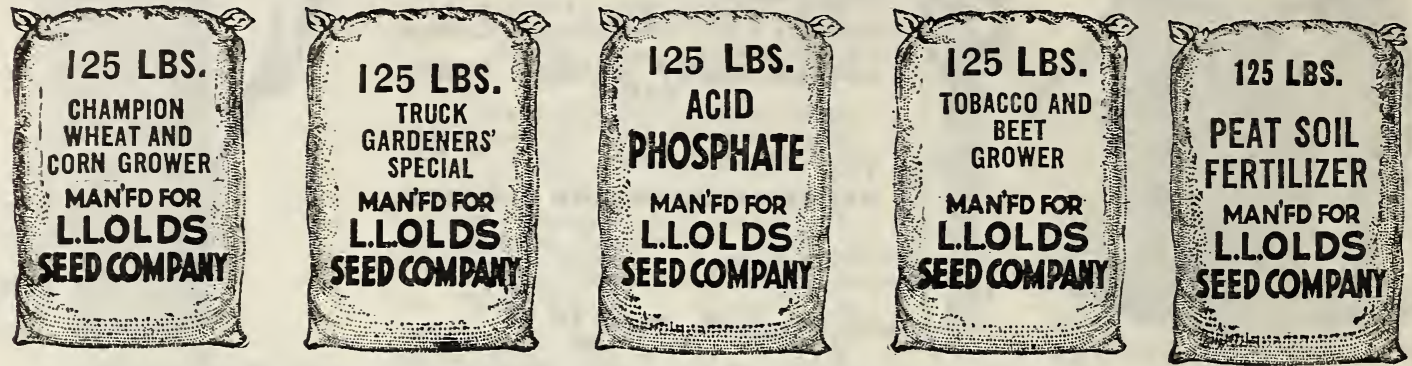

CHAMPION WHEAT AND CORN GROWER. (2-12-2) A high grade complete fertilizer for corn and all grain crops, especially where the soil is thin. We sell more of this than of any other brand. Farmers are learning
that it pays well to use it for their corn crop as it greatly increases the yield. 125 1bs., 2.65; 1,000 lbs., $\$ 18.50$; 2,000 lbs., $\$ 36.00$.

TRUCK GARDENERS' SPECIAL. (4-8-6) A highly concentrated fertilizer for potatoes, truck and garden crops. Strong in nitrogen and potash. Potatoes and truck crops are heavy feeders of plant food, so for the best results use this high grade brand. It pays. 25 lbs., $\$ 1.00 ; 125$ lbs., $\$ 3.25 ; 1,000$ lbs., $\$ 22.50 ; 2,000$ lbs., $\$ 44.00$. ACID PHOSPHATE. (0-20-0) For use in supplementing farm manure. Use 50 lbs. to each load of manure or apply separately 100 to 300 pounds per a cre. $125 \mathrm{lbs} ., \$ 2.25 ; 1,000 \mathrm{lbs}$., $\$ 16.50 ; 2,000 \mathrm{lbs}$., $\$ 32.00$.

TOBACCO AND BEET GROWER. (2-12-6) Specially recommended for tobacco and for sugar beets. Also fine for potatoes. Strong in phosphoric acid and in potash. This fertilizer is really more economical for corn than 2-12-2. It costs more but it gives greater results. $125 \mathrm{lbs}$., $\$ 3.00 ; 1,000 \mathrm{lbs}$., $\$ 21.00 ; 2,000 \mathrm{lbs}$. $\$ 41.00$.

PEAT SOIL FERTILIZER. $(0-12-12)$ For marsh lands. 125 lbs., $\$ 2.95 ; 1,000$ lbs., $\$ 20.50 ; 2,000$ lbs., $\$ 40.00$.

BONE MEAI. (1 1/4-29-0) For roses, shrubbery and flowers. Also fine for lawns. Use 3 to 5 pounds per 100 square feet or for plants one pound to 50 pounds of soil. 25 lbs., $\$ 1.00 ; 125$ lbs., $\$ 3.25 ; 1,0001 b s$., $\$ 25.00$

NITRATE OF SODA. (18-0-0) Very valuable for fruit trees, tobacco plants and nearly all plants in fact, especially to supplement other manures. $200 \mathrm{lbs}$., $\$ 9.50 ; 1,000 \mathrm{lbs}$., $\$ 15.00 ; 2,000 \mathrm{lbs}$., $\$ 88.00$. (In 200 pound sacks.) (Our Fertilizers, except nitrate of soda, are put up in 125 pound sacks. The analysis figures refer to the percentage of each brand-first, of nitrogen, second, of available phosphoric acid, third, of potash. Prices are subject to change. Write for prices when ready to buy as at the time our catalog goes to press prices are not fully established,) "Fertil-
BULLETINS, Free on Application. "Fertilizing Corn," "Fertilizing Potatoes," "Fertilizing Alfalfa," "Fertil BULLETINS, Free, on Application. "Fertilizing COrn," "Fertilizing Potatoes,", "'
in Truck Farming," "Fertilize Your Tomatoes," "Fertilizing Crops on Peat Soil.",

\section{PULVERIZED SHEEP MANURE.}

A pure natural manure taking effect immediately. Very rich in nitrogen, phosphoric acid and potash, the three essentials. No straw or other refuse as in crude manure.

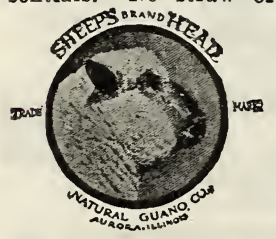

SUPERIOR LIMESTONE.

For Lawns and Gardens.

Superior Limestone, specially prepared, ground very fine, helps greatly in securing a rich, dark green, velvety lawn and it is equally valuable for gardens.
Use 100 pounds for every 600 square feet of lawn or garden. 25 lbs., 35c; 100 lb. sack, $\$ 1.00 ; 500$ lbs., $\$ 4.25 ; 1,000$ Ibs., $\$ 7.50$.

\section{AGRIGULTURAL LIMESTONE.}

$100 \mathrm{lb}$. sack, 60c; $1,000 \mathrm{lbs}$., $\$ 4.50 ; 2,000$ lbs., $\$ 8.00$. Sacks free. $10 \mathrm{c}$ each allowed for empty sacks returned.

30 to 50 Ton Cars, in bulk, $\$ 2.00$ per ton at Mayville, Wis. Freight rates furnished.

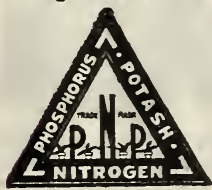

P. N. P. FERN FOOD.

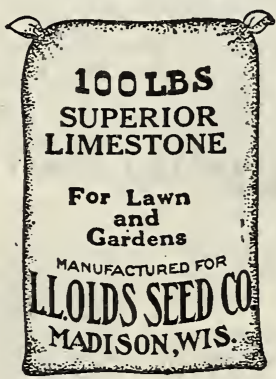

SOILTEX.

Test your soil yourself and see whether it needs lime or not. Complete outfit with table, $\$ 1.00$, postpaid. See page 3 .) Fol taining all the elements essential in growing beautiful ferns. Will revive any fern that is failing and restore to deep green color. 1 oz. size,

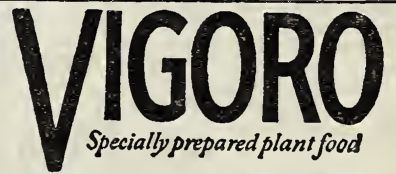

You can have a better lawn, better flowers and better vegetables if you use hardy, disease-free seed and the right plant food. Plants, like human beings, must receive the right nourishment. Vigoro is specially prepared to supply lawns, gardens, flowers, shrubbery

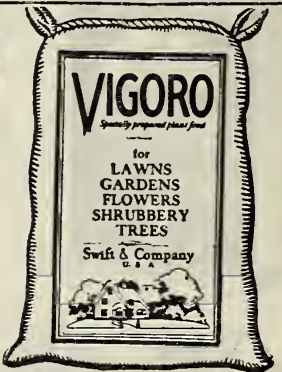
and trees with all of the plant

food elements needed for rapid, sturdy, and beautiful growth. Vigoro is odorless, clean, and easy to apply. It can be sown by hand like grass seed. Use 2 to 4 pounds 100 square feet.

Prices: 5-1b. pkg., 50c; 25-1b. bag, \$1.75; 50-1b. bag, $\$ 3.00 ; 100$ lbs., $\$ 5.00$.

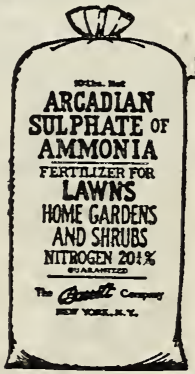

An All-The-Year Fertilize for Garden and House Plants. Simply insert tablet in soil near base of plant.

Postpaid prices: 10 tablets, $15 \mathrm{c}$; 30 tablets, $25 \mathrm{c}$; 100 tablets $75 \mathrm{c}, 1,000, \$ 3.50$.

STIM-U. PLANT.

\section{ARGADIAN SULPHATE OF AMMONIA.}

A wonderful fertilizer for lawns and gardens. Guaranteed 20 per cent am. monia, highly concentrated, quick acting. Ammonia supplies nitrogen, the of Arcadian contains as much Prices: 2-lb. pks. of stable manure. 5-1b. bag, 75c; 10 lbs., \$1.35; 25 lbs., $\$ 2.60 ; 50$ lbs., $\$ 4.00$.

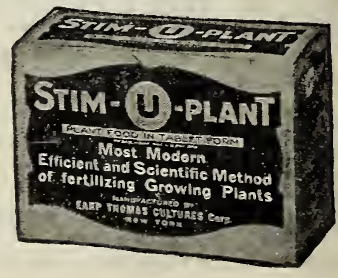




\section{INSECTICIDES AND PLANT FOODS}
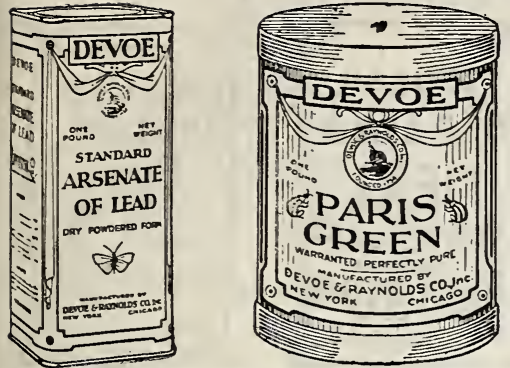

ARSENATE OF IEEAD POWDERED.
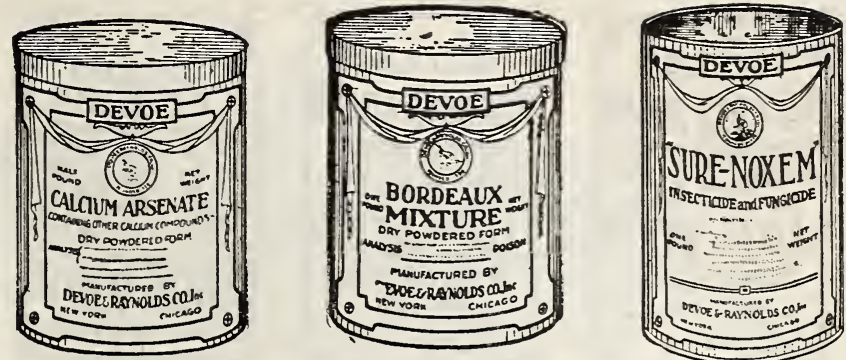

For all leafeating insects.

Prices: $1 / 2$ lb., 25c; 1 lb., 45c; 4 lbs., $\$ 1.15 ; 24$ lbs., $\$ 6.00 ; 96$ lbs., $\$ 23.00$.

PURE PARIS"GREEN. A strong effective poison for pctato bugs, tobacco and other leaf-eating insects.

Prices: 1/4 lb., 20c; 1/2 lb., 30c; 1 lb., 50c; 2 lbs., 95c; 5 lbs., $\$ 2.35 ; 14$ lb. pails at $40 \mathrm{c}$ per pound

DRY CALCIUM ARSENATE. Used in the same manner and for the same purposes as Arsenate of Lead, but

costs less and is still more effective. Sticks to the leaves One application lasts a long time.

Prices: 1/2 lb., 20c; lb., 35c; 4 lbs., 90c; 24 lbs., $\$ 5.00 ; 96$ lbs., $\$ 19.00$

DRY BORDEAUX MIXTURE. The best fungicide for preventing black rot, mildew, blight, scab, etc., on fruit and vegetable plants. Spray potatoes for blight. One pound will make 51) pounds liquid. Can be used just as needed. Prices: 1/2 lb., 25c; 1b., 45c; 4 lbs., \$1.10; 10 lbs., $\$ 2.45 ; 25$ lbs., $\$ 5.50 ; 50$ lbs., $\$ 9.50 ; 1001 b s ., \$ 19.00$.

"SURE NOXEM." "For use on potatoes, cabbage, cauliflower, zcumbers, melons, tomatoes, currants, gooseberries and all other regetables and shrubs. Kills insects of all kinds. Poind carton (sifter top) 25c; $51 \mathrm{~b}$. bag, 75c. DRY LIME SULPHUR. For San Jose scale and common spray. Just as effective as the lime sulphur solution and more easily handled. 1 lb., $40 \mathrm{c} ; 5$ lbs., $\$ 1.40 ; 10 \mathrm{lbs}$., $\$ 2.50 ; 25 \mathrm{lbs}$., $\$ 4.50 ; 50$ lbs., $\$ 8.25 ; 1001 \mathrm{bs}$., $\$ 15.00$ FORMALDEHYDE. For preventing smut in grain, scab on potatoes, etc. Ask for leaflets telling how to use. Price, pound size, $40 \mathrm{c}$. One pound will treat 40 buskels.

NOTICE. All of the above are poisons and are not mailable. Ask for special prices in large quantity.

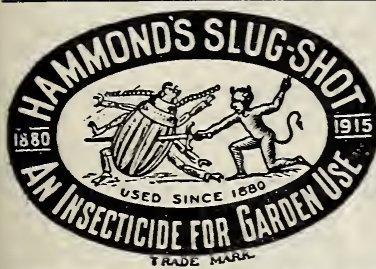

\section{PLANT FOODS}

PLANTPEP.

Plantpep is a well balanced plan food (fertilizer) for potted plants, sweet peas, roses, begonias, cut flowers, shrubs, lawns, gardens, in fact all plant life.

2 oz. size, $15 \mathrm{c} ; 8$ oz. can, $50 \mathrm{c}$; postpaid.

\section{WATCH-EM-GROW PLANT FOOD.}

Are your house plants as nice and healthy as you wish them to be? If not, it may be because you are not feeding them "Watch-emGrow', Plant Food. Contains just the right balance to feed and not stimulate them. Odorless, soluble, highly concentrated, quick-acting.

Large trial package, $10 \mathrm{c}$, postpaid.

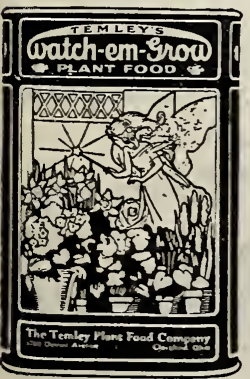

Return empty package for $10 \mathrm{c}$ credit on large can. Big eight ounce can only $50 \mathrm{c}$, postpaid. OYAMA PLANT FOOD. A Wonderful Japanese Discovery. Fine for all $k$ i n d s of plants, ferns, shrubs, roses, bulbs, lawns, berries, fruits a n d flowers. Highly c o n. centrated, eas ily applied a nd economical to use. Never fails to produce won-

Prices: House Plant Size, results. 6 gallons), $25 \mathrm{c}$; by mail, $30 \mathrm{c}$. Garden Size, (makes 32 gallons), $\$ 1.00$; by mail, $\$ 1.10$.

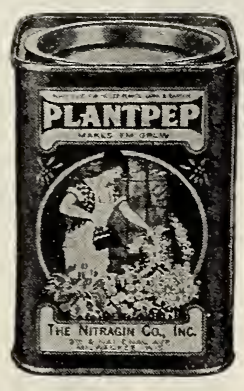

\section{SLUG SHOT.}

currant worms, potato tc. A fungicide as well

rices: $1 \mathrm{lb}$, carton sifter top, $25 \mathrm{c}$; by 0 lbs., \$1.40; 25 lbs. 00; $125 \mathrm{lb}$. keg with ster, \$13.00; $250 \mathrm{lb}$. with duster, $\$ 25.00$.

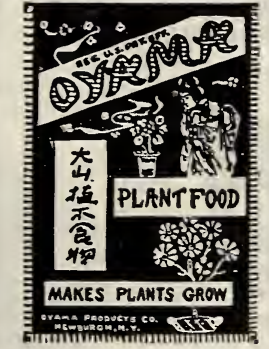

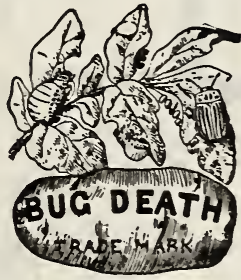
Does not burn the leaves, how ever freely applied. It kills bugs and worms and prevents blight.

Prices: 1 lb. carton with sifter top, 25c; by mail, $35 \mathrm{c}$; 3 lbs. $55 \mathrm{c}$; by mail, $70 \mathrm{c} ; 5$ lbs., $75 \mathrm{c}$ by mail, $\$ 1.00 ; 12 \frac{1}{2}$ lbs., $\$ 1.60$; 100 lbs., $\$ 9.00$.

Order In-
s e c t i cides
shipped with
seeds and save
t r a nsporta-
tion charges.

PYROX. A powerful fungicide Used for spraying potatoes, fruit trees, small fruits and garden crops. Simply mix with cold water and spray.

Lb., 50c; 5 lbs., $\$ 1.90$; 10 lbs., $\$ 3.25$; 25 lbs., $\$ 6.75 ; 50$ lbs., $\$ 11.50 ; 100 \mathrm{lbs}$. $\$ 16.00$. Not mailable.

\section{Black Leaf 40 Kills}

BLACK LEAF 40. A powerful and effective liquid insecticide, for use against aphis, thrips and leafhoppers. Recommended by Experiment Stations and Entomologists. Prices: 1 oz., 35c; 1/2 lb., $\$ 1.25 ; 2$ lbs., $\$ 3.50 ; 10$ Ibs., \$13.50 BLAGK LEAF NICOTINE DUST.

For dusting against aphis on melons, cucumbers, etc.

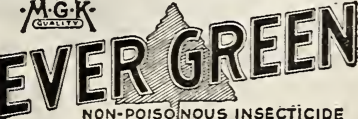

A new, non-poisonous insecticide. Effective against cabbage worms, cucumber and melon beetles, aphis, leaf hoppers, currant worms and most other insects, both chewing and sucking.

Does not injure the most delicate plants and retains its strength indefinitely. Absolutely harmless to man and beast. Easily applied with any style of sprayer. Simply mix with water. Prices: $11 / 2$ oz size (makes 9 gals. spray), 35c; by mail, 40c. 6 oz. size $\$ 1.00$; by mail, $\$ 1.05$. 16 oz. size, $\$ 2.00$; by mail, $\$ 2.10$. 32 oz. size,

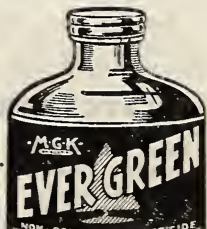
KIILS PIANT INSECTS HARMLESS TO MAN MUESTOCK BIRDS AND DETS

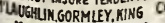
$\$ 3.85$; by mail $\$ 4.00$. 


\section{POULTRY FEEDS, SHELLS, GRIT}
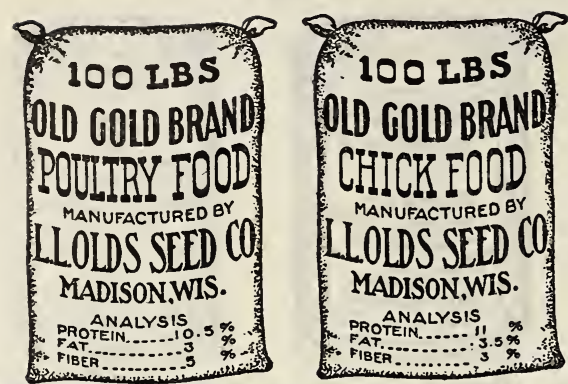

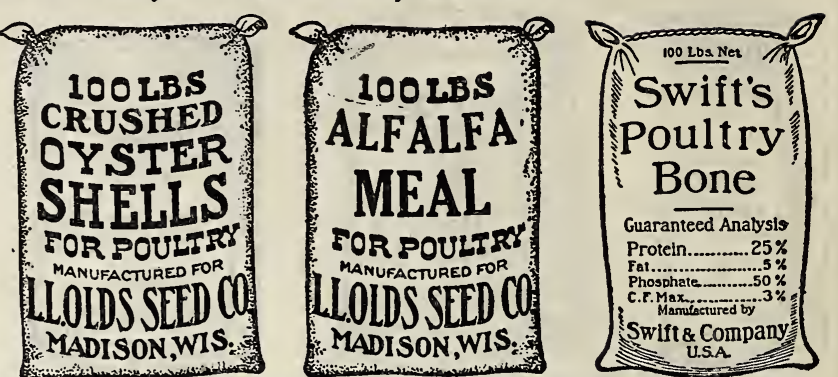

\section{OLD GOLD POULTRY FOOD.}

Olds' Old Gold Poultry Food is a complete feed for laying hens. Contains wheat, cracked corn, sunflower, barley and buckwheat. No grit. Duly analyzed and licensed. Made by us right here at Madison.

Prices: $10-1 \mathrm{~b}$. sack, $30 \mathrm{c} ; 100-1 \mathrm{~b}$. sack, $\$ 2.80 ; 3$ sacks at $\$ 2.70$.

\section{OLD GOLD CHICK FOOD.}

Old Gold Chick Food is a dry food also made by us, suitable for chicks from 4 to 8 weeks old. It contains cracked wheat, cracked corn, hulled oats, millet, etc., but without grit.

Prices: $10-1 b$. sack, 35c; $100-1 b$. sack, $\$ 3.15 ; 3$ sacks at $\$ 3.05$.

(Prices on poultry and chick food are subject to change. Ask for "Weekly Price List of Poultry Feeds and Supplies.")

OYSTER SHELLS. 100-1b. sack, $\$ 1.05 ; 3$ sacks at $\$ 1.00$.

CLAM SHELIS. 100-1b. sack, 95c; 3 sacks at $90 \mathrm{c}$.

SUPERIOR LIME GRIT. 100-1b. sack, 65c; 3 sacks at $60 \mathrm{c}$. ALFALFA MEAL.

For mashes and for mixing with other feeds. Largely used.

No. 1 Medium: $10 \mathrm{lbs}$., 25c; $100 \mathrm{lb}$. sack, $\$ 1.90 ; 3$ sacks at $\$ 1.80$.

No. 1 Fine: $10 \mathrm{lbs} ., 25 \mathrm{c}$; $100 \mathrm{lb}$. sack, $\$ 2.10 ; 3$ sacks at $\$ 2.00$.

\section{SWIFT'S POULTRY BONE}

Largely used for small chicks.

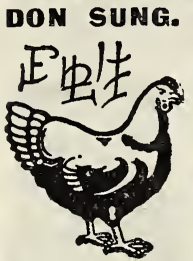

(Chinese for Egg Laying). M a k es Hens Lay. Acts directly on the

Small Size (enough for 15 hens o $n$ e month), $50 \mathrm{c}$, postpaid; Dollar size 3 times 50 cent Size), $\$ 1.00$; Large
Size, $\$ 5.00$, postpaid.

GONKEY'S

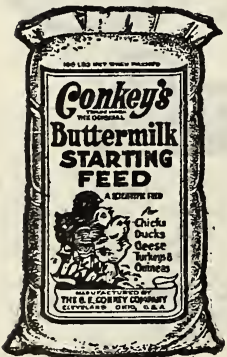
BUTTERTIL STARTING FEED. Gives the
chicks buttercentrated form, with a combination of grains. It is all the chicks need the first 9 weeks except greens, grit clean water and old Gold Chick Food in the lit ter to induce exercise.

Prices: 21/2 lbs., 25c; 5 lbs., $45 \mathrm{c}$; 10 lbs., $75 \mathrm{c} ; 25$ lbs., $\$ 1.45 ; 100$ lbs

BLATCHFORD'S GALF MEAL. Saves Milk-
Saves MoneySaves Moneyter Calves M genuine Milk Substiing all the necessary ele. ments for rapid healthful growth of the calf. Prices: 25 ibs., $\$ 1.40$; 50 lbs., $\$ 2,60$ 100 lbs., $\$ 4.85 ; 300$ lbs., at $\$ 4.75$.

Prices: 25 lbs., \$1.15; 50 lbs., $\$ 2.10 ; 100$ lbs., $\$ 4.00$

GRANULATED GHARGOAL.

50-1b. sack (two sizes, poultry and chick). $\$ 1.35$; 100 lbs., $\$ 2.60$

\section{"GOLD LEAF" TOBACBO}

OWDER:

Highly recommended. 2 lbs., 25c; by mail, 35c; 10 lbs., 85c; 100 lbs. $\$ 6.50$

\section{GONKEY'S BUTTERMILK} GROWING MASH.

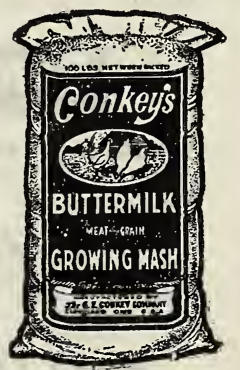
BASKET" EGG MASH. milk in con-

For developing pullets and lbs., $\$ 1.25 ; 100$

BLATCHFORD'S "FILL THE

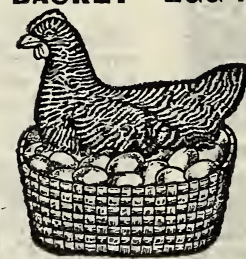

A record

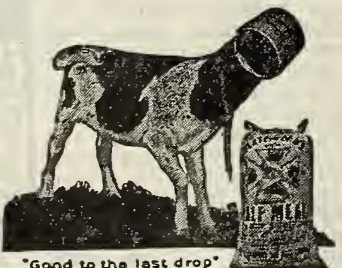

. 300 lbs at $\$ 475$
TRADE-MARK lbs. at $\$ 3.75$. mash for laying $h e n$ s. Contains a of $m$ i l $k$ meat, grains. Ibs., $\$ 1.10$ $\$ 30, \quad 30$; $-94$ MEAL. broilers. It is not enough to start a chick right - it is equally essenthal to help it to termilk Growing Mash is the ideal feed after the eighth week. Follow Conzey's Starting Feed with this Prices: 10 lbs., 60c; 25 lbs., $\$ 4.40$.

PQULTRY GRAINS.

(Prices subject to change. Write for Weekly Price List.)

Feed Wheat, Per $100 \mathrm{lbs}$. Cracked Wheat ............ 3.15

Cracked Corn, coarse . . . . 2.60

Cracked Corn, fine .......... 2.70

Sunflower $\ldots \ldots \ldots \ldots \ldots \ldots \ldots 8.8 .00$

Feed Millet $\ldots \ldots \ldots \ldots \ldots \ldots 3.20$

Steel Cut Oat Meal.......... 4.25

Meat Meal (Tankage) ......... 4.50

\section{GONKEY'S Y-O.}

Cod Liver Oil and Yeast are two essential ingredients in poultry ra tions. Conkey's Y.O furnishes thes two items in economical form.

Prices: 1 lb., 65c; by mail, 75c; 2 lbs., $\$ 1.15$; by mail, $\$ 1.30$; 5 lbs. $\$ 2.50 ; 25$ lbs., $\$ 11.25$.

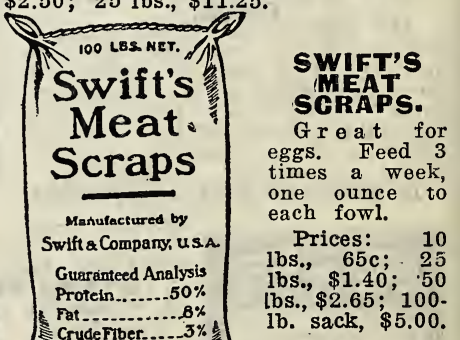
的

\section{BLATGHFORD'S}

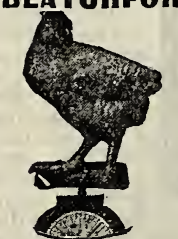

GHIGK MASH. Prices: 25 Sixteen essential ingredients in this $\mathrm{high}$. gra d o growing mas h. Makes rapid $g$ row $t h$ shields chick f $\mathrm{r}$ o m White Diarrhea.

Prices: 4 lbs., $2 \mathrm{r} / 4 \mathrm{lbs}$ at 8 weeks! $\$ 1.35 ; 100 \mathrm{lbs}$. $\$ 4.70 ; 300$ lbs. at $\$ 4.60$. penced ration 
A "CONKEY CORNER" FOR YOUR POULTRY HOUSE.

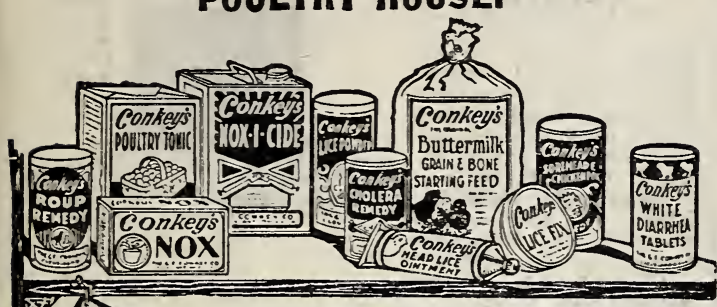

Keep an assortment of these old, de pendable remedies on hand for emergenConkey's Roup Remedy-The old standby $25 \mathrm{c}, 50 \mathrm{c}$, and $\$ 1.00 ; 30 \mathrm{c}, 55 \mathrm{c}$ and \$1.10, postpaid.

Roup Pills. For individual treatment. $25 \mathrm{c}$, postpaid.

Canker Special. Relieves instantly. 50c; 55c, postpaid. Sulphur Candles. $15 \mathrm{c}$, postpaid.

Limber Neck Remedy. $50 \mathrm{c}$; postpaid, 55c.

Scaly Leg Remedy. 25c; 30c, postpaid.

White Diarrhea Remedy. A reliable preparation. Use

in the drinking water. $25 \mathrm{c}$ and $50 \mathrm{c} ; 30 \mathrm{c}$ and $55 \mathrm{c}$, postpaid. Head Lice Ointment. $10 \mathrm{c}$ and $25 \mathrm{c} ; 15 \mathrm{c}$ and $30 \mathrm{c}$, postpaid.

Poultry Worm Remedy. 25c; 30c, postpaid.

Cholera Remedy. $25 \mathrm{c}$ and $50 \mathrm{c}$; $30 \mathrm{c}$ and $55 \mathrm{c}$, postpaid.

Gape Remedy. $25 \mathrm{c}$ and $50 \mathrm{c}$; $30 \mathrm{c}$ and $55 \mathrm{c}$, postpaid.

Mite Liquid. Qt., 60c; 2 qts,, 90c; 1 gal., $\$ 1.50$.

Poultry Tonic. $11 / 2$ lbs., $25 \mathrm{c}$; by mail, $35 \mathrm{c}$; $31 / 4$ lbs., $50 \mathrm{c}$; by mail, 70c; 12 lbs., $\$ 1.60 ; 25$ lbs., $\$ 3.00$.

Lice Powder. 5 ozs., 20c; by mail, 25c; 15 ozs., $35 \mathrm{c}$; by mail, $40 \mathrm{c} ; 48$ ozs., $75 \mathrm{c}$; by mail, $95 \mathrm{c}$.

Noxicide. A wonderful disinfectant and germicide.

Pt., 50c; qt., 80c; 2 qts., $\$ 1.30$; gallon, $\$ 2.00$.

Fly Knocker. For stockmen and dairymen, Qt. 60c;

2 qts., 90c; gal., \$1.50; 5 gals., \$7.25. Not mailable. FREE, with orders for $\$ 1.00$, Conkey Poultry Book.

PRATT'S REMEDIES.
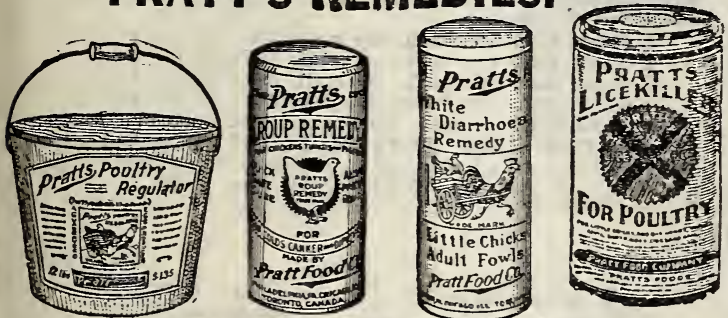

PRATT'S POULTRY REGULATOR.

Pkgs, 25c and 50c; 35c and 65c postpaid: 9 Ibs. $\$ 1.10$;

$12-1 b$, p $\$ 1.40 ; 12$-lb pail, $\$ 1.65 ; 25-1 b$ pail, $\$ 3.00$

Pratt's Roup Powder, $25 \mathrm{c}$ and $50 \mathrm{c}$, postpaid.

Pratt's Roup Tablets, $25 \mathrm{c}$ and $50 \mathrm{c}$ postpaid.

White Diarrhoea Remedy, 25c and 50c, postpaid.

Poultry and Stock Disinfectant. Kills germs. Pint, 40c.

qt., 55c; 2 qts.; $\$ 1.00$; gal., $\$ 1.65$. Not mailable.

Red Mite Special. Qt., 50c; 2 qts., 90c. Not mailable.

Powdered Lice Killer. 5 ozs., 12c; by mail 17c; lb.,

$25 \mathrm{c}$; by mail, $30 \mathrm{c} ; 2 \frac{1}{2}$ lbs., $50 \mathrm{c}$; by mail, $60 \mathrm{c}$.

Pratt's Poultry Worm Powder. 50c; by mail, $65 \mathrm{c}$.

Pratt's Special Remedy. For indigestion, sour crop and

dysentery, $25 \mathrm{c}$, postpaid.

Pratt's Fly Chaser. Gal., \$1.50; 5 gals., \$6.50.

Ask for "Pratt's Practical Pointers on Poultry.'

Lee's Germozone Tablets. 65c, postpaid.
RELIABLE COAL BURNING BROODERS.

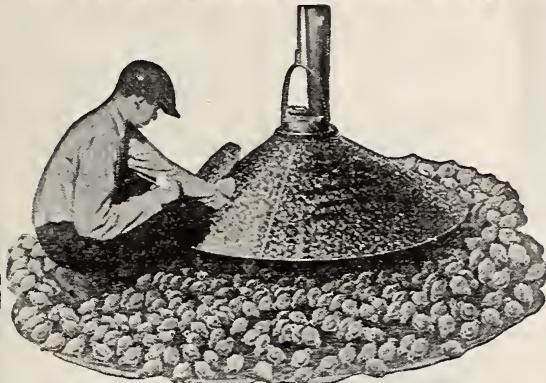

coal or coke and can be

used in any kind of building or room in any kind of weather. Has all the latest mprovement s A u t o matic $\mathrm{R}$ e $\mathrm{g}$ u la tor, steady heat $\begin{array}{ll}\text { a n d } & \text { sares } \\ \text { fuel. } & \text { Fully } \\ \end{array}$ guaranteed.

No. 9-42 inch canopr, 500 chicks.......... $\$ 16.50$

No. $10-52$ inch canopy, 1000 chicks........... 21.50

No. $11-60$ inch canopy, 1200 chicks........... 26.50

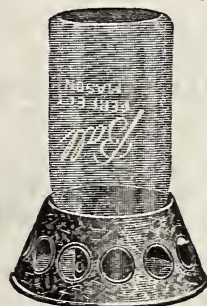

Gantter Water
SPIRALET LEG BANDS. (Celluloid). Colors, light blue, dark blue, red. pink, yellow, black, amber, light green, dark green, and white. Mention the colors preferred. Three sizes: Asiatic, American, Leghorn $25,30 \mathrm{c} ; 100,85 \mathrm{c}$, postpaid.

(Spirals also for pigeons and for bantams and for turkeys, all at the same priceirALET NUMBER CLIPS.

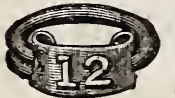

GPIRALET NUMBER CLIPS. Easily and quickly put on the spiralets. Will star on. Two sizes. Prices, either size, $12,20 \mathrm{c} ; 25,35 \mathrm{c} ; 100, \$ 1.00$, postpaid.

BANDETTES.

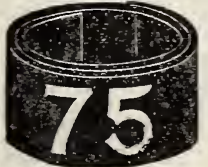

A new style of celluloid leg band numbered consecutively. 5 colorsblue, red, sellow, green and pink. 3 sizes-Asiatic, American, Leghorn. Box of $25,65 \mathrm{c} ; 4$ boxes, $\$ 2.00$, postpaid. (Name size and color wanted.)

Double Clinch Leg Bands: 12 for 18c; 25 for 30c; $100,80 \mathrm{c}$ postpaid. Smith Sealed Leg Bands; 12 for $35 \mathrm{c} ; 25,60 \mathrm{c} ; 100, \$ 1.75$. Pettey Poultry Punch: 30c, postpaid.

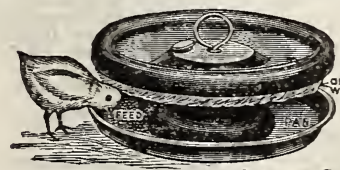

\section{AUTOMATIE GHIGK GREASER.}

Every chick his own doctor. As he eats from the pan his head is thoroughly greased. Price, $\$ 1.50$; by mail, $\$ 1.65$.

\section{GARBOLINEUM.}

For preserving wood, A very valuable article. Gal., $\$ 1.50 ; 5$ gals., $\$ 6.50$.

\section{ACCREDITED BABY CHICKS.}

Hatched in one of Wisconsin's largest hatcheries, right here at Madison, from healthy, purebred stock. All chicks have the State Trade Mark, "Accredited Chicks,", which means that every flock has been personally inspected by an inspector of the Wisconsin Department of Markets.

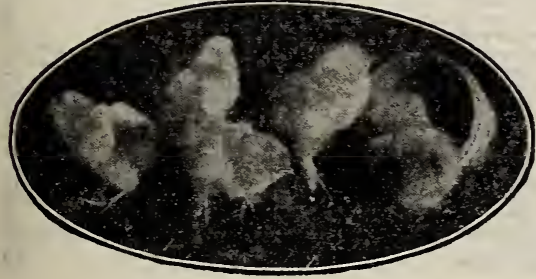

Prices for Single Comb White, Brown and Buff Ieghorns, Anconas and Black Minorcas: 25 chicks, $\$ 5.00 ; 50$ chicks, $\$ 8.50 ; 100$ chicks, $\$ 15.00 ; 500$ chicks, $\$ 70.00 ; 1000$ chicks, $\$ 135.00$.

Prices for Barred Rocks, Single Comb and Rose Comb Rhode Island Reds: 25 chicks, $\$ 5.25 ; 50$ chicks, $\$ 9.75 ; 100$ chicks, $\$ 17.50 ; 500$ chicks, $\$ 85.00 ; 1,000$ chicks, $\$ 165.00$.

Prices for White Rocks, White Wyandottes, Buff Orpingtons: 25 chicks, $\$ 5.50 ; 50$ chicks, $\$ 10.50 ; 100$ chicks, $\$ 20.00 ; 500$ chicks, $\$ 95.00 ; 1,000$ chicks, $\$ 185.00$.

After May 15th a $25 \%$ reduction from the above prices.

All chicks are shipped by prepaid parcel post, $100 \%$ safe arrival guaranteed. Order early naming approximate date wanted. 


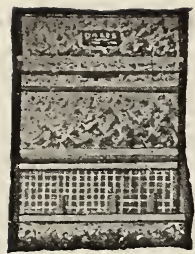

Handy Hopper. MUTANDLTH FEEDER.

Most satisfactory for feeding buttermilk withopenings, 20 inch. es long, 65c; by

IMPROVED HANDY HOPPER.

Has swinging front adjustable to suit any kind of dry mash.

No. 12. Length 12 inches, $\$ 1.75$

No. 13. Length 18 inches, 2.25

No. 14. Length 24 inches, 2.75

No. 15. Length 36 inches, 3.90

AUTOMATIC CHICK FOUNTAIN.

Made to fit fruit jar. Pan style. Price, $15 \mathrm{c}$; by mail, $20 \mathrm{c}$.

McCandlish Improved Tin

Buttermilk Feeders

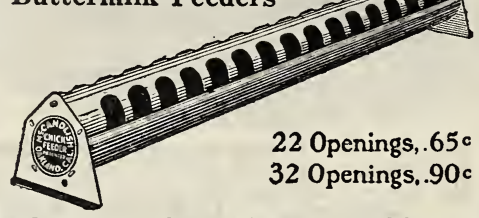

openings, 30 inches long, 90c; by mail, $\$ 1.00$. (We can furnish both sizes with revolving rod instead of hood at

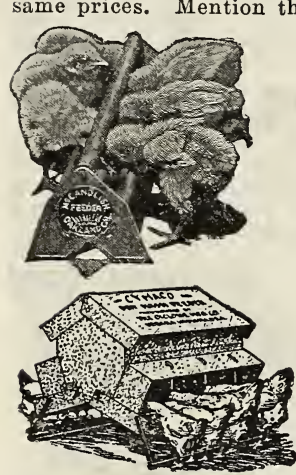

Dry Mash Feeder.
MCEANDLISH C H $\mathbf{G}$ FEEDER. Also used for drinking. Made of galvanized iron. The revolving top rod prevents perching. 20 in., $50 \mathrm{c}$; by mail, $0 \mathrm{c} ; 30$ in., $75 \mathrm{c}$; by mail, 85c. FEEDER. For all kinds of dry feed. Made of steel.

12 inch, capacity $1 / 2$ bu., $\$ 2.25$ 24 inch, capacity 1 bu., $\$ 3.25$.

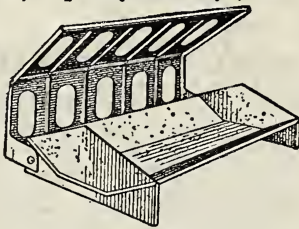

Cymaco Chick Trough.

CYMACO GHICK TROUGH. Galvanized metal. 10 inch, 30c; by mail, $40 \mathrm{c}$. 20 inch, $40 \mathrm{c}$; by mail, $50 \mathrm{c}$.

plyin pur A COIUMBUS FREEZEIESS FOUNTAIN. A new style. 2 gal. size, $\$ 3.50 ; 3$ gal. size, $\$ 4.00 ; 5$ gal. size, $\$ 5.00$.

\section{UTILITY POULTRY}

\section{FEEDER}

ord in poultry feeders. For all kinds of feed. Frame $42 \times 30$, feeder 42 inches high. Holds 100 pounds of mash. Total feeding space of 9 feet. Substantially made, well finished. Price, $\$ 6.50$.

GRIT AND SHEIL

BOX. For grit, shells

and charcoal. Made of

steel, 3 compartments.

C h i c k size, 90c;

poultry size, $\$ 1.20$.

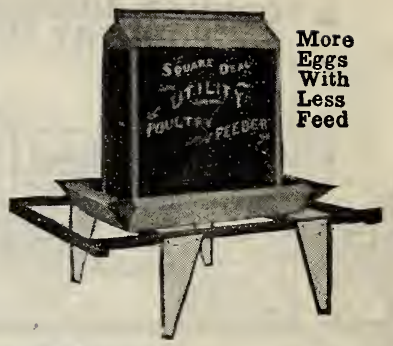

\section{PARK COOP.}

A handsome

parking coop

that will tele-

scope. Made of metal.

Price, $\$ 4.00$

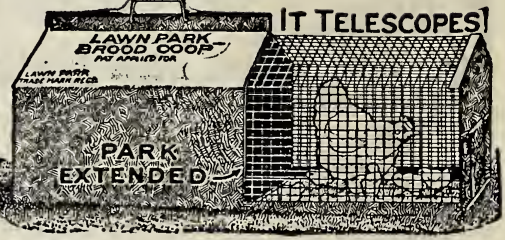

for $\$ 21.00$

NON-PARKING BROOD COOP.

Similar to the preceding without park.

Price, $\$ 2.00 ; 6$ for $\$ 10.50$.

EYRIE SHIPPING COOPS. For shipping by express. Single bird size, $60 \mathrm{c}$; pair, 90c; trio, $\$ 1.00$.

SELF-LOCKING EGG CARTONS.

For marketing eggs. 12, 25c; by

mail, 30c; $100, \$ 1.75 ; 1,000$, $\$ 15.00$.

"BABIE" CHICK FEEDER. "Babie" Chick Feeder.

Conserves feed. Accommodates 40 to 50 chicks.

Price, $\$ 1.25 ; 6$ for $\$ 6.75$.

PORCELAIN NEST EGGS. Dozen, 35c; by mail, $50 \mathrm{c}$.

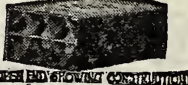

PARGEL POST EGG GARRIERS.

Safe delivery by parcel post assured.

1 dozen size, 35c each; by mail, $45 \mathrm{c} ; 12$ for $\$ 3.15$

2 dozen size, $45 \mathrm{c}$ each; by mail, $55 \mathrm{c} ; 12$ for $\$ 4.15$

3 dozen size, 55c each; by mail, 65c; 12 for $\$ 5.25$

4 dozen size, 70c each; by mail, $80 \mathrm{c} ; 12$ for $\$ 6.75$

TRAP NESTS. Single, front only, 35c each.

IMPROVED DROP BOTTOM FOUNT. Combines the good qualities of all fountains. 2 qt. size, $\$ 1.00 ; 1$ gal.

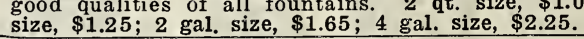

\begin{tabular}{|c|c|}
\hline & \\
\hline n, Ageratum....63 & Chicory, Cress.... \\
\hline ulialfa............, 5 & $\begin{array}{l}\text { Chinese Wool Flower }, 66 \\
\text { Chrysanthemum...64,79,80 }\end{array}$ \\
\hline & Cinnamon Vine......... \\
\hline$y=$ & Clematis.. \\
\hline 63.7 & Clover Seed \\
\hline stor & \\
\hline ter & \\
\hline aby & $\mathrm{Cc}$ \\
\hline$a b$ & \\
\hline & Creeping $\mathrm{B}$ \\
\hline & $\begin{array}{l}\text { Cucumber.. } \\
\text { Cultivators. }\end{array}$ \\
\hline$\because$ & Cypress Vine.. \\
\hline ean & Dahli \\
\hline & \\
\hline 63, & inium \\
\hline $\begin{array}{l}.63 \\
.78\end{array}$ & Diai \\
\hline .88 & $\begin{array}{l}\text { Digit. } \\
\text { Dill. }\end{array}$ \\
\hline & \\
\hline & \\
\hline & $\mathrm{Eg}$ \\
\hline Flower.......63 & $\begin{array}{l}\text { Emmer. } \\
\text { Everlasting Fiowers.66, }\end{array}$ \\
\hline & False Drago \\
\hline & $\mathrm{F}$ \\
\hline & $\begin{array}{l}\mathrm{Fe} \\
\mathrm{Fe}\end{array}$ \\
\hline $\mathrm{d} \dot{\mathrm{Fl}}$ & \\
\hline eed & \\
\hline bury Beil & Fo \\
\hline$y . .$. & \\
\hline tc & $\mathrm{Fr}$ \\
\hline & Fi \\
\hline & cides \\
\hline & \\
\hline & \\
\hline & \\
\hline
\end{tabular}

\section{INDEX}

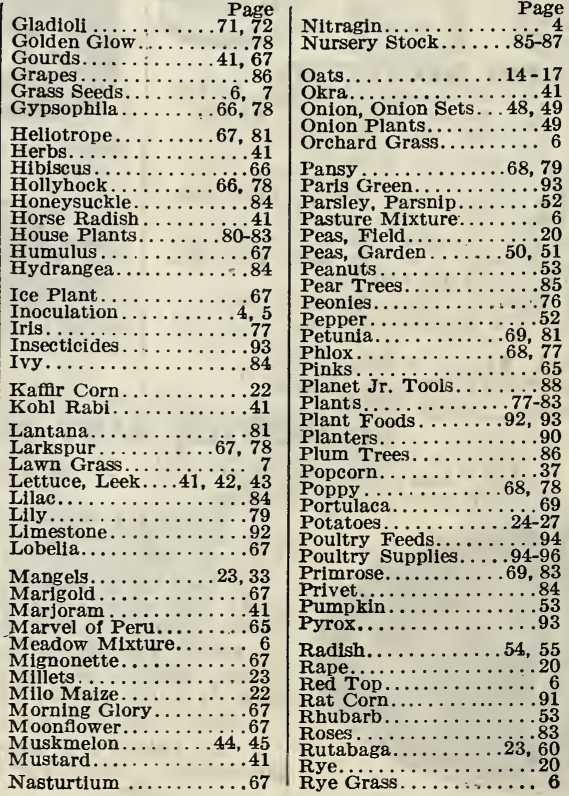

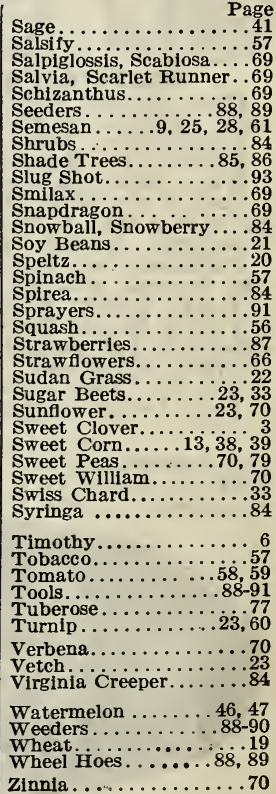




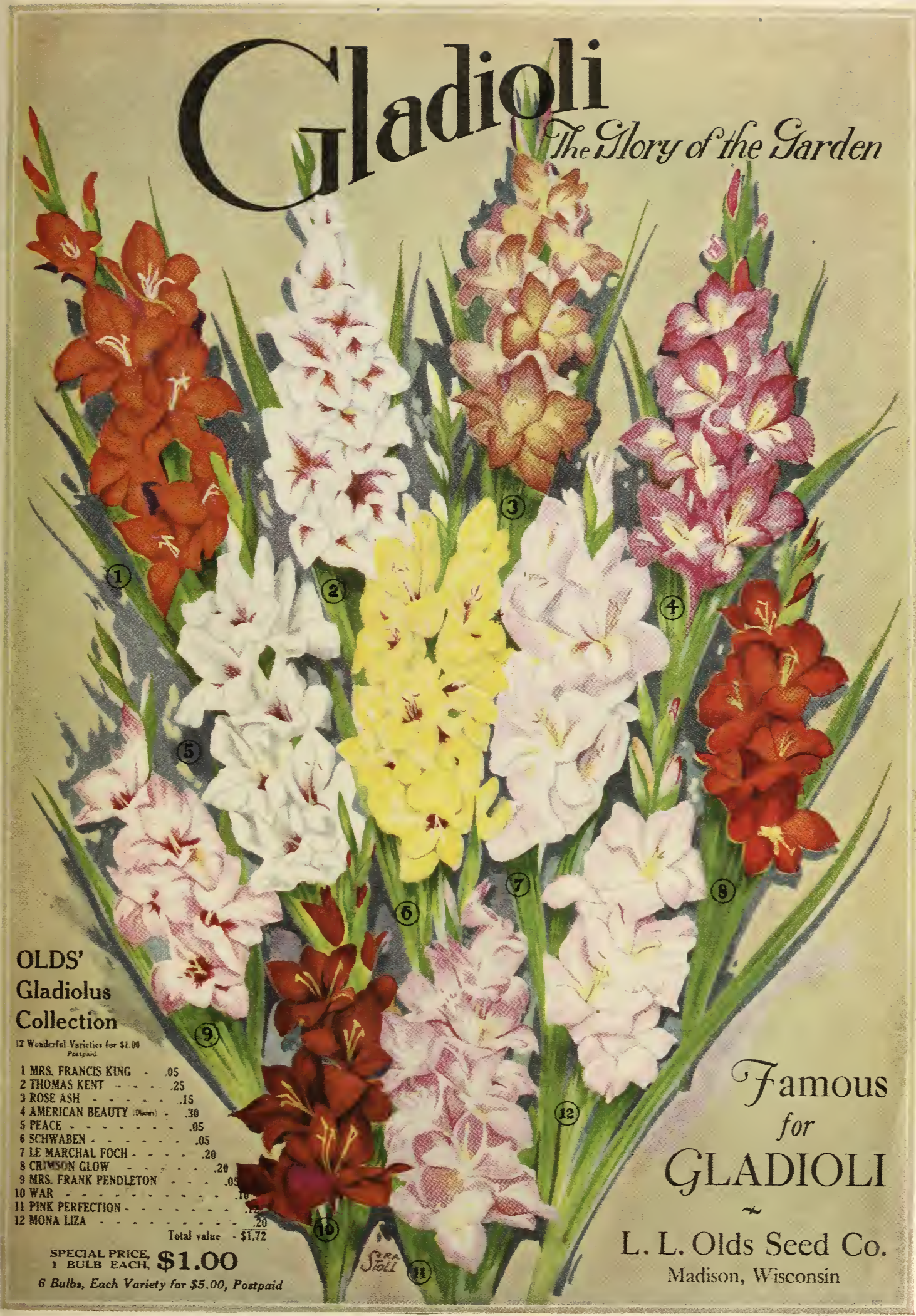




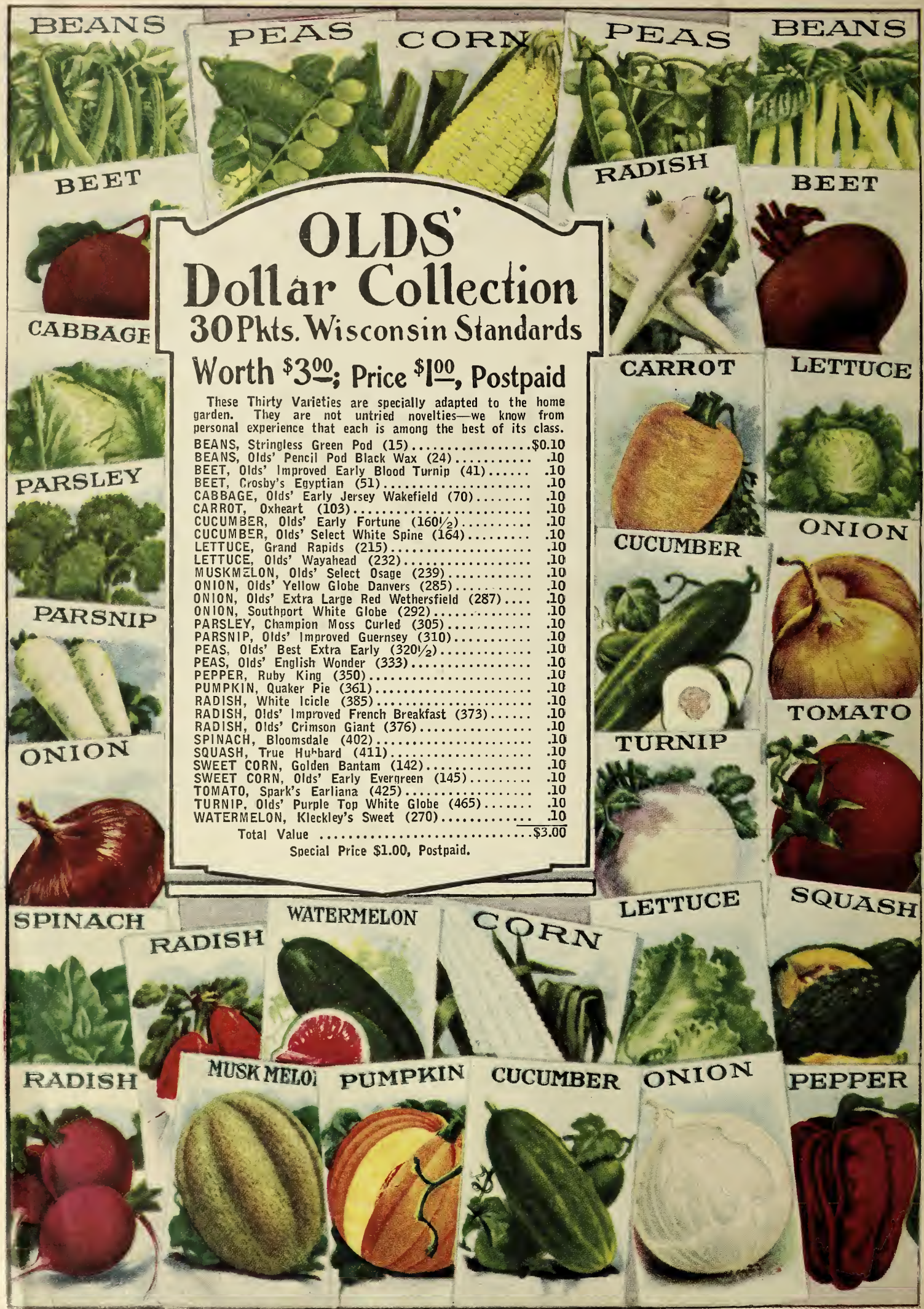

